UNIVERSIDADE DE SÃO PAULO

FACULDADE DE FILOSOFIA, LETRAS E CIÊNCIAS HUMANAS

DEPARTAMENTO DE HISTÓRIA

PROGRAMA DE PÓS-GRADUAÇÃO EM HISTÓRIA SOCIAL

\title{
EXUBERÂNCIA E INVISIBILIDADE. POPULAÇÕES MOVENTES E CULTURA EM SÃO PAULO, 1942 ao início dos anos 70
}

\author{
Elena Pájaro Peres
}

Tese de doutoramento apresentada ao Programa de Pós-Graduação em História Social, do Departamento de História da Faculdade de Filosofia, Letras e Ciências Humanas da Universidade de São Paulo

Orientador: Prof. Dr. Nicolau Sevcenko 


\section{AGRADECIMENTOS}

Em primeiro lugar agradeço ao professor Nicolau Sevcenko, orientador deste trabalho, pela oportunidade de com ele compartilhar esse percurso de história e encantamento. Amizade e admiração sempre.

À Cristina Carletti, gratidão pelo acolhimento e generosidade singular.

Aos professores Jorge Grespan e José Moura Gonçalves Filho, que participaram de meu exame de qualificação colocando questionamentos pertinentes. Ao professor Zeca ainda por ter em suas aulas considerado com seriedade e competência minhas indagações e me levado a refletir profundamente sobre a questão da invisibilidade e da cultura dos grupos populares.

Ao professor Marcus Vinicius Mazzari pela atenção e respeito com que me recebeu em seu curso, oferecendo-me a oportunidade de conhecer os caminhos de Fausto e adentrar mais uma vez no universo majestoso e pequenino das veredas de Guimarães. Agradeço ao professor Alcides Villaça pela acolhida generosa com que recebeu "os amigos do André", repartindo conosco sua sensibilidade de poeta.

À professora Dra Marta Maria Soban Tanaka da Faculdade de Arquitetura e Urbanismo da USP pela atenção dispensada e o empréstimo de documentação. À professora Ana Maria Domingues de Oliveira do Departamento de Literatura da UNESP de Assis por ter possibilitado a consulta ao acervo do escritor João Antônio. Esse agradecimento se estende aos pesquisadores que me receberam nessa instituição.

Aos professores Elias Thomé Saliba que, com seu bom humor característico, sempre teve uma palavra, um sorriso amistoso, uma sugestão vital. Aos professores Maria Inêz Machado Borges Pinto e Paulo Koguruma pela confiança e encorajamento. Ao professor Augutin Wernet (in memorian) por nos conceder o privilégio de ouvir e aprender com suas evocações da Floresta Negra e sua filosofia poética. Saudades.

Ao professor Paulo César Garcez Marins que fez observações e importantes sugestões bibliográficas. À professora Maria Cristina Cortez 
Wissenbach pela acolhida afetuosa. Aos professores José Guilherme Cantor Magnani e Ítalo Moriconi Júnior pela recepção gentil e interesse pelo tema do trabalho.

À Fundação de Amparo à Pesquisa do Estado de São Paulo pelo imprescindível apoio financeiro, sem o qual não teria sido possível a conclusão deste trabalho.

Agradeço às instituições que possibilitaram a reprodução de parte do material fotográfico utilizado nesta tese, entre elas ao Instituto Moreira Salles, em nome de seus funcionários Cídio e Virgília, e ao Arquivo do Estado de São Paulo, setor de Arquivos Especiais-Iconográfico. Ás bibliotecas da Universidade de São Paulo e da Pontifícia Universidade Católica de São Paulo às quais recorri constantemente. À turma do "xérox do Luis" de novo: Zezinho, Marcos, Márcia e André.

Aos amigos da pós-graduação com os quais pude conviver durante esse tempo, em especial ao André Luis Rodrigues e ao Nelson Aprobato Filho, com quem dividi por dois anos o Deviração. Estudos Teórico-Metodológicos, espaço em que pudemos discutir livremente nossas inquietações. As devirações por São Paulo serão lembradas. Ao André ainda por fornecer generosamente informações importantes, discutir idéias, sugerir mudanças e, principalmente, pela amizade atenta e afetuosa.

Ao Humberto Lima Pimentel, de São Paulo e de Caetité, um agradecimento especial pelas dicas, sugestões e auxílio prestado no trabalho com fotografias, pelos importantes esclarecimentos na área de cinema e pelo empréstimo de material e bibliografia. Aos amigos sempre presentes com livros, filmes, música, palavras, gestos, apoio e muitas risadas: Jane, Mi e Lígia, Ismara e Marcelo, João e Tânia, Fábio Brito, Luis Maria, Mary, Toninho, Helena e todos aqueles com quem compartilhei momentos importantes nesses quase cinco anos. Agradeço também aos meus familiares que me ensinaram a perceber o encantamento da vida, em especial meu pai, Ismael (in memorian), e minha mãe, Dulce.

Ao Nelson com quem desde 1988 percorri inúmeros caminhos. quantos mais ainda estarão por percorrer...Tempo encantado, irreversível trajeto. 


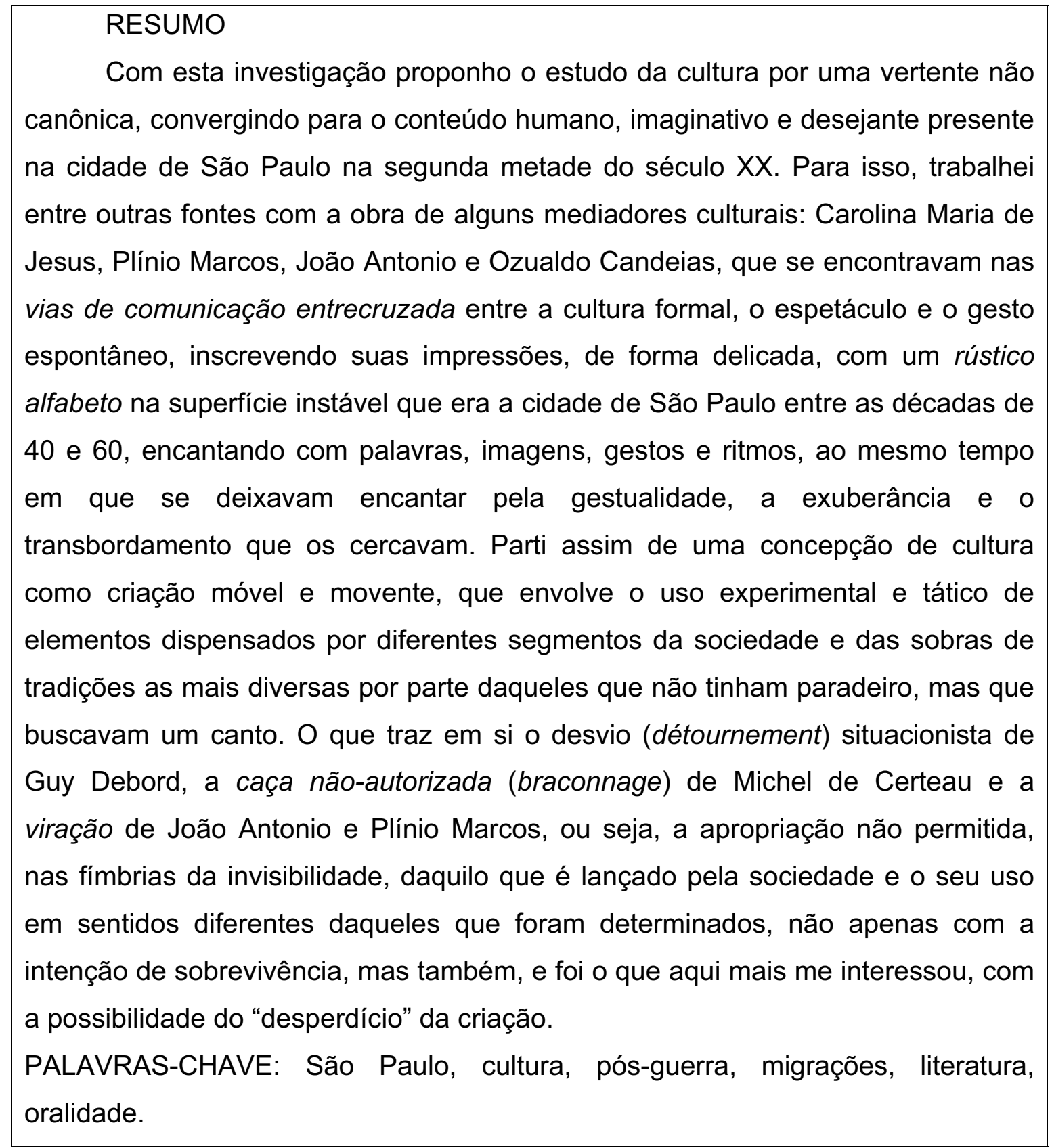




Abstract
This research proposes the study of culture under a non canonical view,
which converges to the human, imaginative and desiring content found in the city
of São Paulo during the second half of the 20th century. To that end, I researched
the works of the following cultural mediators, among others: Carolina Maria de
Jesus, Plínio Marcos, João Antonio, and Ozualdo Candeias, who were at the
communication crossroads of formal culture, the spectacle and the spontaneous
gesture, and used a rustic alphabet to write with grace their impressions on the
unstable surface which was the city of São Paulo between the 1940s and 1960s.
They enchanted people with their words, images, and rhythms while they became
themselves enchanted by the gestures, the exuberance and the overflow of
emotions around them. My starting point was therefore a concept of culture as
creation on the move and movable, which involves the experimental and tactical
use by drifters - looking for a haven and a song - of elements cast away by
different segments of society, and leftovers of diverse traditions. This carries in
itself Guy Debord's situational deviation (détournement), Michel de Certeau's
poach (braconnage), and João Antonio's viração, that is, unallowed appropriation,
on the fringes of invisibility, of what society throws away to be used with meanings
that are different from those that were previously determined, not only for the
purpose of survival, but - and this has interested me most - as a possibility of
"waste" of creation.
KEY WORDs: São Paulo, culture, post-war, migrations, literature, orality.


SUMÁRIO

A SOMBRA DOS INVISíveIS

Tessitura Visual

07

Desejos, Deslocamentos, Situações 55

Capítulo I - São Paulo, a Cidade Movente

1.1 Em Busca de um Canto 72

1.2 No Vale das Borboletas o Canto dos Encantados 81

CAPítulo II - A Dança dos Viradores

2.1 Virações, desvios e caça 134

2.3 O Arrepio das Classes Amedrontadas,

a Fuga dos Povos Assustadiços

162

Capítulo III - Transpasse CULtURal

3.1 Inscrição Delicada de "Rústico Alfabeto" em Superfície Instável 189

3.2 Mínimos gestos divergentes - Considerações Finais 208

RELAÇÃo de Fontes E ACERVOS $\quad 214$

$\begin{array}{ll}\text { BibLIOGRAFIA } & 224\end{array}$ 


\section{A SOMBRA DOS INVISÍVEIS}

Ao pousar entre as folhas, com as asas postas, esse animal astuto, devido ao mimetismo, desaparecia por completo no ambiente, de modo que nem sequer o mais voraz de seus inimigos o poderia localizar ali.

Essa borboleta era, portanto, capaz de tornar-se invisivel para proteger-se. Mas bastava continuar a folhear o livro para travar conhecimento com outras que obtinham o mesmo resultado precisamente mediante a mais manifesta e espalhafatosa visibilidade.

(Thomas Mann, Dr. Fausto) 


\section{Tessitura Visual}

Ele apertou minha mão, ajoelhou-se resoluto à minha frente e eu vi como ele, com admirável habilidade, foi desprendendo suavemente minha sombra da relva, começando pela cabeça e indo até os pés; e por fim, depois de enrolá-la e dobrá-la toda, guardou-a em seu bolso. Então se levantou, inclinou-se mais uma vez diante de mim e retirou-se indo em direção das roseiras. ${ }^{1}$

Peter Schlemihl, o soturno personagem de Adelbert von Chamisso, num momento de intenso desespero, vendeu o que só depois reconheceria como um inefável bem, sua sombra, despojando-se assim dos imperativos que o mantinham inserido em uma comunidade, retirando de si a possibilidade de dar relevo às superfícies, marcar a ambiência e ser redefinido por ela. ${ }^{2}$

Schlemihl não vislumbrou alternativa diante de um mundo que o expropriava de algo essencial: a possibilidade de realizar seus mais profundos e preservados desejos, cultivados por gerações inteiras antes dele e abatidos pela imposição de novos padrões de pretensão. Esse mundo, a que fora atirado com um certo pesar, Ihe determinava quais ambições deveria carregar, Ihe impunha quais desejos deveria substituir, quais deles poderia mostrar e quais, enfim, deveria afastar com desprezo, sem ao menos compreendê-los. Adiando sempre para mais além o desfrute da felicidade, num interminável caminho sem retorno. ${ }^{3}$

\footnotetext{
${ }^{1}$ Adelbert von Chamisso. A História Maravilhosa de Peter Schlemihl, tradução Marcus Vinicius Mazzari, $2^{\mathrm{a}}$ ed., São Paulo: Estação Liberdade, 2003, pp. 39-41. Obra redigida no ano de 1813.

${ }^{2}$ Schlemihl projetava sua sombra "com um certo ar de nobre desprezo e de pouco-caso (...)."Adelbert von Chamisso, op.cit., p.37. A morfologia da superfície em que a sombra se inscreve, interfere na sua forma e a informação que a sombra presta é tanto a respeito das superfícies sobre a qual incide quanto sobre o objeto que a causa, sendo mais informativa sobre as superfícies. Cf. Michael Baxandal. Sombras e Luzes, tradução de Antônio de Pádua Danesi, São Paulo: EDUSP, 1997, pp.84 e 86.

3 "Caro amigo, quem, de forma leviana, dá um passo que seja para fora da estrada correta é arrastado subitamente a outros caminhos, que o levam para cada vez mais baixo, (...)." Adelbert von Chamisso, op.cit., p. 93
} 


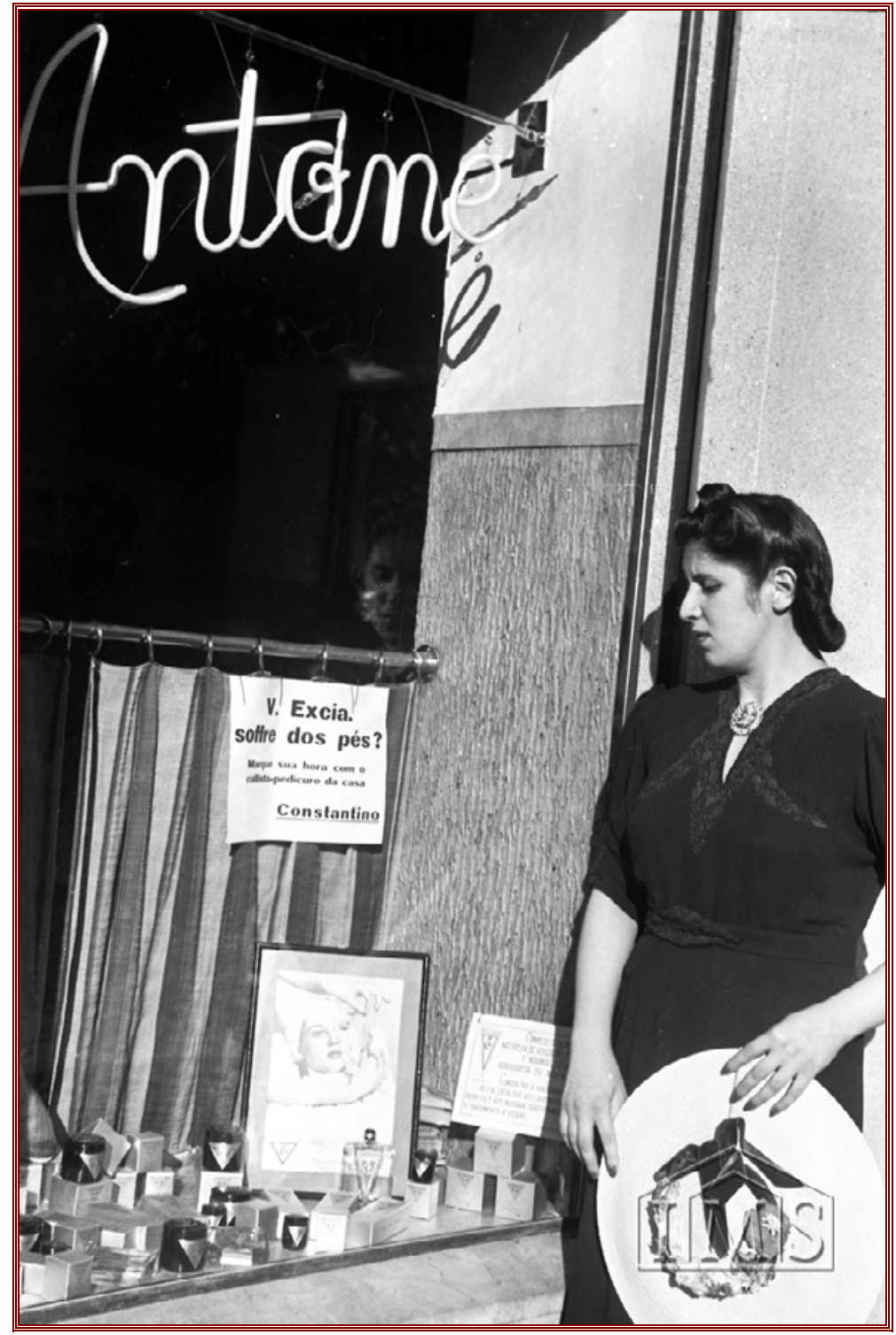

Imagem 1 - Mulher olhando vitrine com produtos de beleza, São Paulo, SP, 1940. Hildegard Rosenthal / Acervo Instituto Moreira Salles. Código: 005HRP020.005

Não vendeu sua sombra para sobreviver, o fez vertiginosamente imaginando que assim poderia experimentar tudo aquilo que the fora prometido e a que não tinha acesso por pertencer a um extrato espoliado da população. Era um migrante, sem rumo definido, disposto inicialmente a colaborar, possuidor de um quase nada material, nada além daquilo que podia carregar junto ao corpo. 


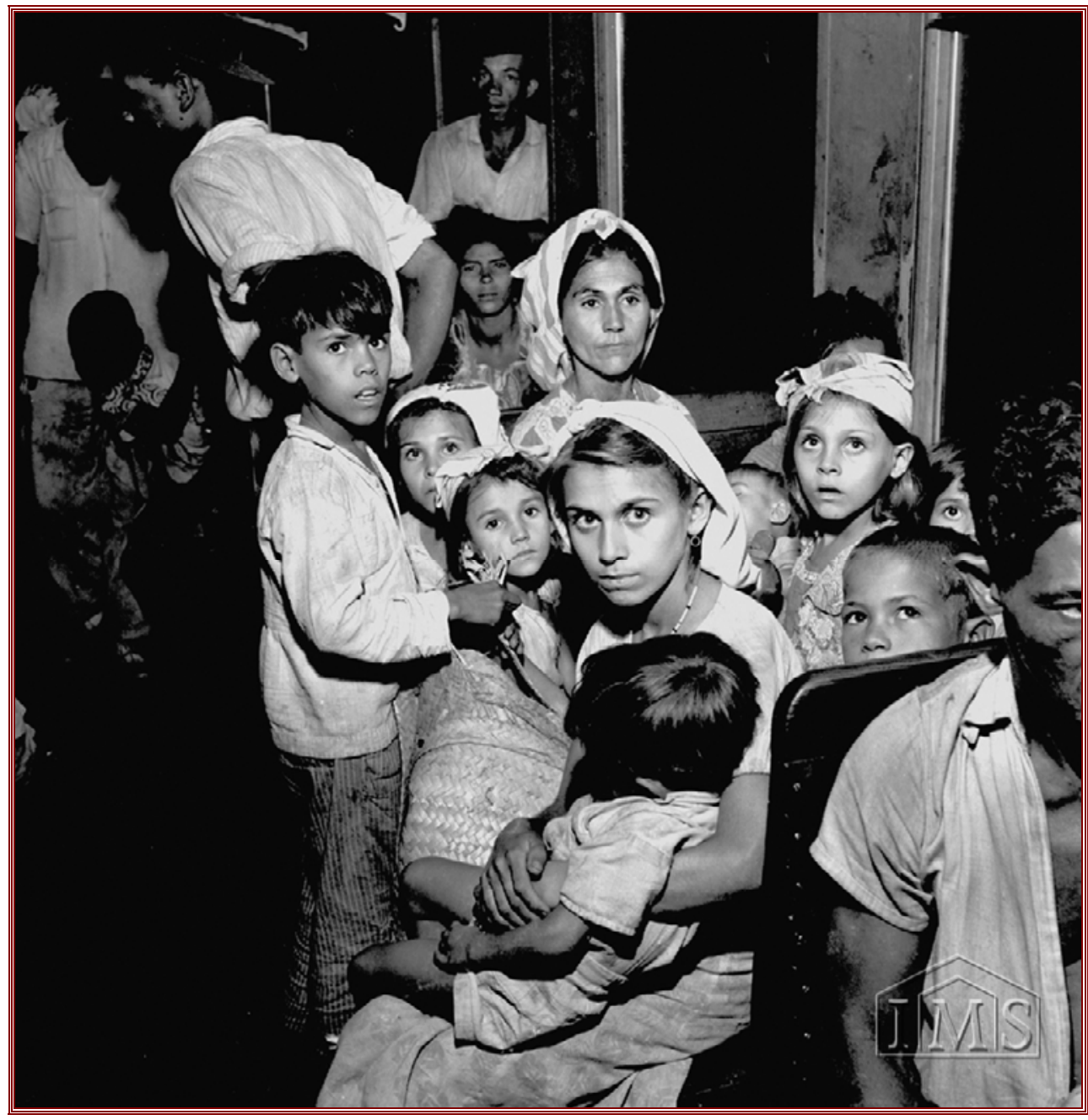

Imagem 2 - "Retirantes", São Paulo, SP, 1952.

Henry Ballot / Acervo Instituto Moreira Salles.

Depois de uma travessia feliz, mas para mim um tanto penosa, alcançamos finalmente o porto. Tão logo cheguei em terra com o bote, joguei às costas os meus poucos pertences e, abrindo caminho entre a multidão fervilhante, entrei em uma casa próxima - a mais acanhada de todas - em cuja frente pendia um letreiro. Solicitei um quarto, o empregado mediu-me com o olhar, de cima a baixo, e conduziu-me ao sótão. ${ }^{4}$

\footnotetext{
${ }^{4}$ Adelbert von Chamisso, op.cit., p.29.
} 
Era do sótão da casa "mais acanhada de todas", onde Schlemihl se hospedara, que tentaria sair rapidamente, procurando o contato com o mundo esplendoroso da riqueza, no qual, com "modesta esperança", considerava que encontraria a felicidade.

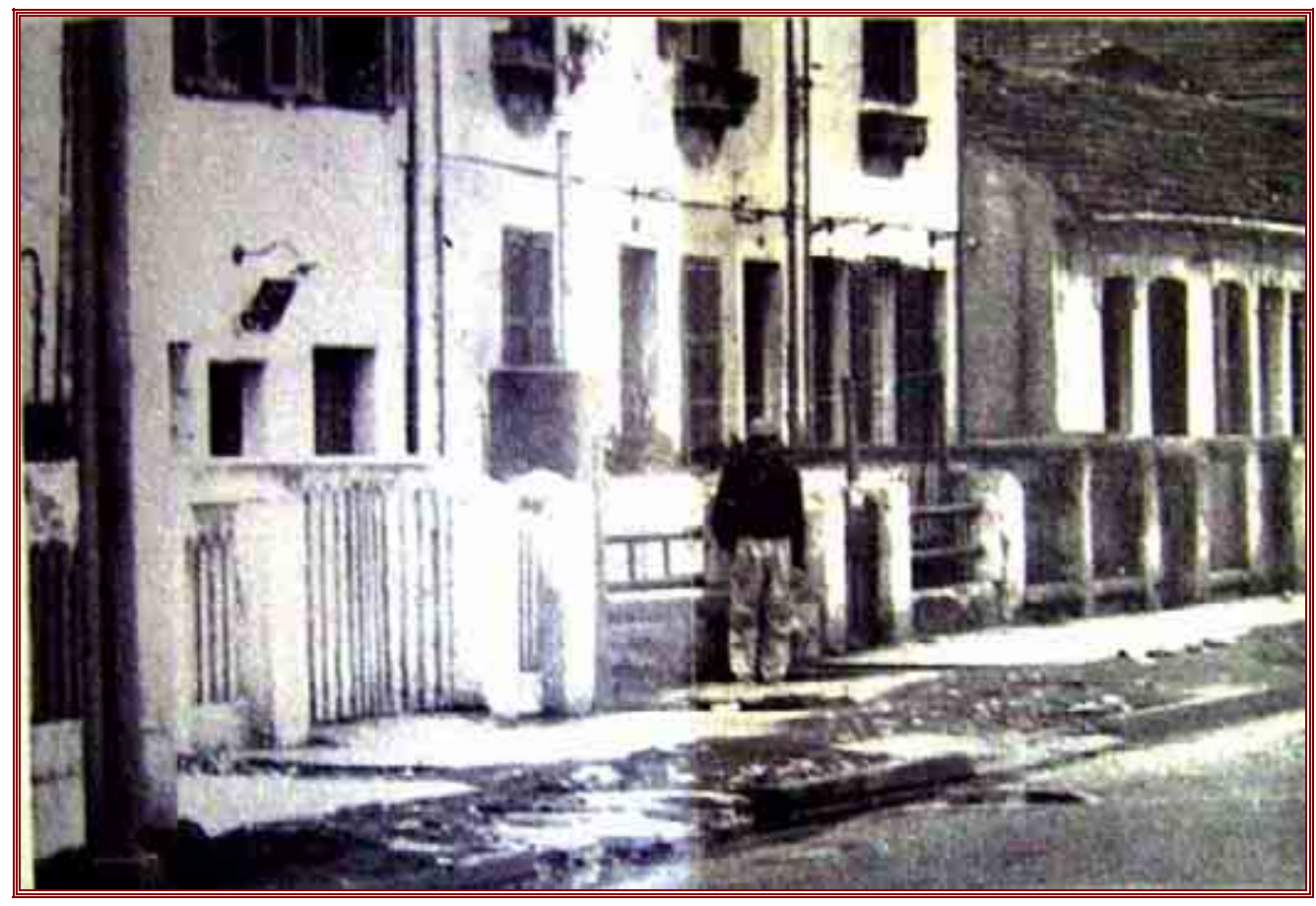

Imagem 3 - "Uma São Paulo que nem todos conhecem". Luis Fernando Kiehl, Revista Paulistania, nº73, 1967-68.

Tirei com o lenço o pó de meus sapatos, ajeitei a gravata e, invocando a ajuda de Deus, toquei a campainha. (...) tive a honra de ser chamado ao parque onde o senhor John passeava com um pequeno grupo de pessoas. Eu logo reconheci o homem pelo esplendor de sua robusta satisfação interior. Ele recebeu-me muito bem, como um rico costuma acolher a um pobre diabo, até mesmo virou-se para mim, sem contudo se afastar dos demais, e tomou de minhas mãos a carta que eu Ihe estendia. (...)

Rompeu o lacre, mas não a conversa, que versava sobre riqueza, e investiu: 'Perdoem-me a expressão, mas quem não é dono de pelo menos um milhão não passa de um patife.' - 'É a pura verdade', exclamei, tomado por um sentimento forte e transbordante. ${ }^{5}$

\footnotetext{
${ }^{5}$ Adelbert von Chamisso, op.cit., p. 30.
} 
A travessia de Peter de fato começou nesse instante de concordância, quando publicamente deixou transbordar sua aflição, reconhecendo a hierarquia que o degradava. Seu desprendimento completou-se imediatamente depois com a aquiescência da proposta extravagante de um estranho que oferecia pela sua sombra a bolsa da fortuna.

'A bolsa da fortuna de Fortunato!', exclamei, interrompendo-o; e, embora sentisse muito medo, com aquela única palavra ele apoderou-se totalmente dos meus sentidos. Sobreveio-me uma vertigem e era como se ducados duplos brilhassem diante dos meus olhos. ${ }^{6}$

Tornou-se assim um ser desenraizado, sem nada que o ligasse ao solo, sem nada para o que se voltar e reconhecer. Apesar de rico, era apontado na rua com terror e escárnio. A tristeza abateu-se sobre Peter que buscou estratagemas para ocultar sua deficiência e continuar vivendo entre os homens: evitou a luz, numa desenfreada ciofilia, apoderou-se do ninho encantado que the garantia a invisibilidade, escondeu-se por trás da sombra de outros. Contudo, se permanecesse por muito tempo no mesmo local, seria sempre, inevitavelmente, descoberto.

Ante a eminência de ter de vender também sua alma para recuperar a sombra, travou uma luta atroz entre a sedução dessa troca e a sua vontade interna, optando finalmente pelo deslocamento contínuo que the surgiu como única saída para evitar a negociação. Não estava mais disposto a colaborar.

\footnotetext{
${ }^{6}$ Adelbert von Chamisso, op.cit., p. 39.
} 


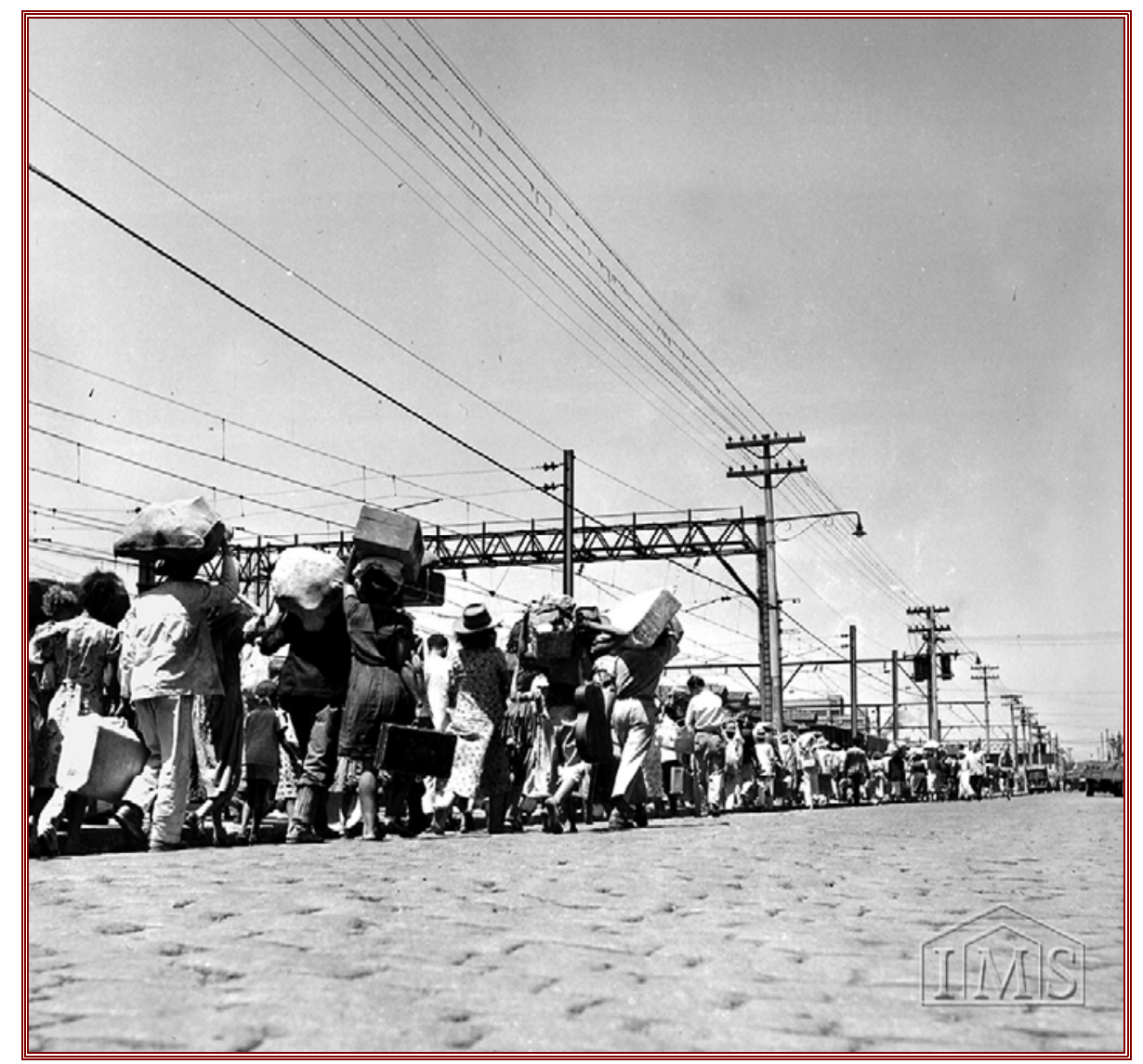

Imagem 4 - Retirantes caminhando, São Paulo, SP, 1952. Henry Ballot / Acervo Instituto Moreira Salles

Essa alternativa de movimentação proposta em meados do século XIX por Chamisso, ele próprio um nobre desterrado, acostumado com as andanças, condizia com a realidade de uma Europa que se via obrigada a conviver em suas cidades, com contingentes cada vez maiores de populações vindas dos mais diferentes confins. ${ }^{7}$ Eram camponeses em sua maioria, impulsionados pela

\footnotetext{
${ }^{7}$ Chamisso nasceu em 1781 na França. Sua família foi desterrada em 1790 como conseqüência da Revolução Francesa e obrigada a vagar pela Europa sem paradeiro certo. Ainda jovem ingressou no exército prussiano, onde serviu por mais de dez anos. Depois viveu um tempo em Berlim e decidiu retornar à França para tornarse professor em um liceu. Na França se sentiu alemão e talvez por isso resolveu retornar a Berlim onde concluiu seus estudos em ciências naturais. Contudo percebeu que também não se sentia alemão. Tentou atenuar sua angústia viajando ao redor do mundo por três anos como naturalista em uma expedição exploratória, inclusive visitando o Brasil em 1815. Após essa aventura fixou-se novamente em Berlim tornando-se diretor do Jardim Botânico e dedicando-se à poesia. Cf. pósfacio de Thomas Mann e notas do tradutor em Chamisso, op. cit..
} 
desestruturação das comunidades tradicionais e pela necessidade premente da busca por melhores condições de vida. ${ }^{8}$

A partir de 1870, com a Revolução Científico-Tecnológica, os deslocamentos populacionais tornaram-se mais intensos, dado o aumento da oferta e rapidez dos transportes e da ampliação do alcance dos meios de comunicação e informação. Isso tudo aliado a uma crescente demanda por mão de obra nos centros urbanos. ${ }^{9}$

Muitos imigrantes seguiram para a América, especialmente para os Estados Unidos, com a esperança de adquirirem terras, dinheiro e, se possível, retornar. Outros fugiam de situações de perseguição política ou religiosa. Uma parcela significativa chegou ao Brasil e incluiu-se aqui, juntamente com a população pobre local, oriunda de outras migrações, num infindável ciclo de novos deslocamentos de cidade a cidade, de bairro a bairro, de moradia em moradia.

A história de Schlemihl pode servir como uma alegoria para a compreensão do que ocorreu com esses viajantes e da constante hesitação que os perseguia. Entretanto, muitos deles jamais negociaram sua sombra e acabaram por se transformar num eclipse para todos aqueles que gostariam que o mundo fosse como o vislumbrado pelo demônio de Laplace: "simples e límpido, sem sombra, sem obscuridade (...)", no qual o homem não tem lugar, porque nesse mundo ele

está na obscuridade impenetrável que constitui o correlato lógico dum mundo totalmente iluminado porque não tem relevo, ponto fora do mundo, fonte incognoscivel de luz. ${ }^{10}$

Esses migrantes deslocaram-se carregando consigo fragmentos de tudo o que um dia foram, levando adiante tradições culturais submersas nas mais profundas camadas da memória, nem sempre consideradas apropriadas para os

\footnotetext{
${ }^{8}$ Eric Hobsbawm. A Era do Capital, 1848-1875, tradução de Luciano Costa Neto, $5^{\text {a }}$ ed., Rio de Janeiro: Paz e Terra,1997, pp.271-89.

9 A Revolução Científico-Tecnológica é também conhecida como Segunda Revolução Industrial. Cf. Geoffrey Barraclough. Introdução à História Contemporânea, tradução de Álvaro Cabral, São Paulo: Círculo do Livro, s.d., capítulo II.

${ }^{10}$ Ilya Prigogine e Isabelle Stengers. A Nova Aliança. A Metamorfose da Ciência, tradução de Miguel Faria e Maria Joaquina Machado Trincheira, Brasília: Editora Universidade de Brasília, 1997, pp.61-2. No grego skiá,âs, a sombra, é o personagem não convidado trazido por um conviva (como sua sombra).
} 
novos cenários que iriam encontrar, mas que se constituíam por substratos íntimos e de forte conotação coletiva tendentes a se mostrar nos momentos de criação, de incerteza ou de perigo. ${ }^{11}$ Nas cidades aglomeraram-se com seres provenientes de outras incursões, interpenetrando suas sombras de maneira não isenta de conflitos, disputando desconhecidas superfícies de inscrição, compondo uma conturbada tessitura visual marcada por temporalidades diversas, ocupando os mesmos espaços. ${ }^{12}$

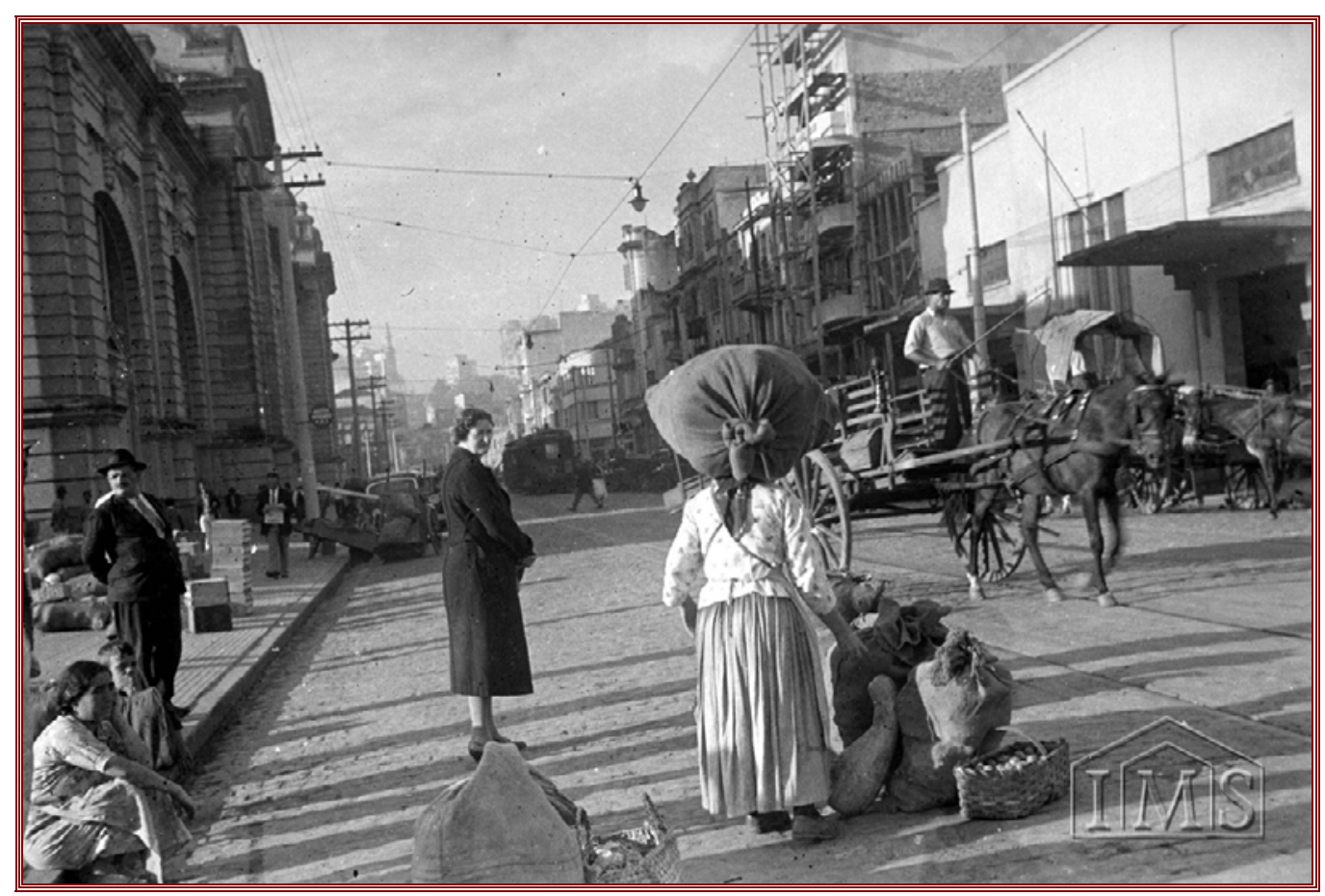

Imagem 5 - Projeção de sombras na zona cerealista. Proximidades do Mercado Municipal, São Paulo, SP, 1940. Hildegard Rosenthal / Acervo Instituto Moreira Salles. Código: 005HR027

\footnotetext{
${ }^{11}$ Como no conto de Machado de Assis, "A Cartomante" em que o personagem Camilo, perturbado, sem saber qual decisão tomar diante de um momento que lhe parecia crucial, resolve pôr de lado seu racionalismo de verniz e perceber que "do fundo das camadas morais emergiam alguns fantasmas de outro tempo, as velhas crenças, as superstições antigas." Nesse instante, salta do tílburi e decide consultar a cartomante. ASSIS, Machado de Contos: Uma Antologia, volume II, seleção, introdução e notas John Gledson, $2^{a}$ ed., São Paulo: Companhia das Letras, 2004, p.260.

${ }^{12}$ Textura ou tessitura, "palavra que de certa forma invoca o sentido do tato, mas visualmente consiste quase que unicamente de sombra pura - auto-sombras muito pequenas, sombras derivadas, sombreados obliquos/inclinados." Baxandall, op. cit., p.151. A tessitura não pode ser percebida através de uma visão panorâmica, é preciso olhar de baixo para sentir. Sobre a diferença entre o olhar panorâmico e o olhar por baixo, cf. Michel de Certeau. "Practices of Space" in Marshal Blonsky (ed.). On Signs, Baltimore, Maryland: The Jonhs Hopkins University Press, 1985, pp. 122-145.
} 
O Estado de São Paulo foi um dos pólos de atração dos imigrantes que chegaram ao Brasil. Eles foram continuamente seduzidos pelas oportunidades de trabalho decorrentes do crescimento da economia cafeeira, e pelas propostas dos agentes arregimentadores. ${ }^{13}$ Durante todo o período da chamada grande imigração, final do século XIX e início do XX, a cidade de São Paulo, ponto de maior convergência dos deslocados, conviveu com a diversidade étnica que ocupava as ruas dos bairros operários, dando um tom cosmopolita à metrópole poliglota. $^{14}$

Nos anos 30 e 40, a imigração tendeu a declinar afetada no âmbito internacional pela crise de 29 , pela restrição à emigração por parte dos países europeus e pela eclosão da Segunda Guerra Mundial. ${ }^{15}$ No âmbito nacional a entrada de estrangeiros "indesejáveis" foi cerceada pela implantação de uma legislação discriminatória ${ }^{16}$, expressiva do projeto étnico-político do governo estadonovista e que culminou com a proibição da imigração em $1941 .{ }^{17}$

Entretanto, os contingentes internos - em deslocamentos constantes e infindáveis desde o período colonial, agravados após a Lei de Terras de 1850 continuaram chegando a São Paulo. ${ }^{18}$ Com a abolição da escravatura em 1888 ,

\footnotetext{
${ }^{13}$ Alvim analisou a ação dos agentes arregimentadores na Itália, que agiam já na década de 1870, e como os cafeicultores do Oeste paulista, a partir de 1885, organizaram uma política imigratória que previa a arregimentação de imigrantes pela Sociedade Promotora de Imigração (SPI) e pelas Companhias de Navegação, provendo o Estado de São Paulo “de mão-de-obra farta e barata”. Zuleika M. F. Alvim. Brava Gente! Os Italianos em São Paulo, São Paulo: Brasiliense, 1986, pp. 40-54. Segundo Herbert Klein, em 1900 os imigrantes correspondiam a $7 \%$ da população nacional e $21 \%$ da população do Estado de São Paulo, sendo que nenhum outro Estado atingiu índices tão altos. Herbert Klein. A Imigração Espanhola no Brasil, São Paulo: Editora Sumaré/FAPESP, 1994, p.28.

${ }^{14}$ Sobre a forte atração exercida pela cidade de São Paulo no início do século cf. Nicolau Sevcenko. Orfeu Extático na Metrópole. São Paulo, Sociedade e Cultura nos Frementes Anos 20, São Paulo: Companhia das Letras, 1992, pp.108-109. Segundo Sevcenko, o mito da "Babel Invertida" formulado por Alberto Torres e adaptado para São Paulo pelo jornalista J. A. Nogueira forneceu um sentido "para os magotes de estranhos, balbuciando suas línguas exdrúxulas, que se acotovelam impacientes por todos os recantos de São Paulo.', op. cit., p. 37.

${ }^{15}$ Boris Fausto. Historiografia da Imigração para São Paulo, São Paulo: Editora Sumaré/FAPESP, 1994, p.48.

16 “Após 1930 o governo federal enveredou para uma política nitidamente restritiva, o que já vinha sendo observado desde 1921, só que de forma mais branda." Maria Luiza Tucci Carneiro. O Anti-Semitismo na Era Vargas: fantasmas de uma geração (1930-1945), 2a ed., São Paulo: Brasiliense, 1995, p.158. Os alvos principais dessa discriminação foram os judeus, os japoneses e os alemães.

17 "Relatório das Atividades do Conselho de Imigração e Colonização no ano de 1944", Revista de Imigração e Colonização, vol. 1, mar. 1945, p.17.

18 Sobre a camada dos desclassificados que no Brasil colonial caracterizava-se "pela fluidez, pela instabilidade, pelo trabalho esporádico, incerto e aleatório" ver Laura de Mello e Souza. Os Desclassificados
} 
aos inúmeros negros que ganhavam a vida pelas ruas de São Paulo, juntaram-se, paulatinamente, os que procuravam uma colocação, abandonando as fazendas e as pequenas cidades. ${ }^{19}$

Esses grupos moventes vinham em ondas sucessivas de ocupação, principalmente após os anos 30, impulsionados pela falta de perspectivas nos locais de origem e também pela tradição caminhante. ${ }^{20}$ Essa tradição exigia que ao menos um ente de cada família tentasse a sorte em paragens mais promissoras, ansiando por encontrar uma vida que possibilitasse, no futuro, mesmo que a duras penas, a dedicação de menos tempo às imposições da necessidade e mais tempo ao lazer, se possível, enviando recursos para os que ficaram e voltando anos depois trazendo elementos que denotassem sua passagem pela cidade grande. Os deslocamentos eram feitos por caminhos desviantes, com paradas múltiplas e itinerários os mais incertos. ${ }^{21}$

Mas, somadas as léguas e deduzidos os desvios, vinham eles sempre para o sul, na direção das maitacas viajoras. ${ }^{22}$

do Ouro. A Pobreza Mineira no Século XVIII, $3^{\mathrm{a}}$ ed, Rio de Janeiro: Graal, 1990, p.63 e especialmente o cap. 2; "Da Utilidade dos Vadios".A Lei de Terras, promulgada em 18/09/1850, restringia o acesso à propriedade fundiária, impedindo que os desprovidos de recursos pudessem adquirir uma parcela para si, uma vez que deixava como única alternativa a compra. Isso incentivou a migração para as cidades. $\mathrm{O}$ artigo $1^{\circ}$ determinava "Ficam proibidas as aquisições de terras devolutas por outro título que não seja o de compra." Apud Raquel Rolnik. A Cidade e a Lei: Legislação, Política Urbana e Territórios na Cidade de São Paulo. São Paulo: Studio Nobel/FAPESP, 1977, p. 23.

${ }^{19}$ Sobre a movimentação dos escravos de ganho na cidade de São Paulo no século XIX ver Maria Odila Leite da Silva Dias. Quotidiano e Poder em São Paulo no século XIX, São Paulo: Brasiliense, 1984. Sobre as migrações ocasionadas pelo fim da escravidão cf. Maria Cristina Cortez Wissenbach. "Da escravidão à liberdade: dimensões de uma privacidade possível" in SEVCENKO, Nicolau (org.) História da Vida Privada no Brasil, vol 3, São Paulo: Companhia das Letras, 1998, pp.49-130.

${ }^{20}$ O fluxo migratório já existia antes de 1929, mas, segundo José Álvaro Moisés, após esse ano, devido a crise mundial que provocou imensas perdas para o setor agrário exportador, milhares de famílias chegaram às grandes cidades do sul, à procura de uma vida melhor. Cf. Greve de Massa e Crise Política (Estudo da Greve dos 300 Mil em São Paulo - 1953-54), São Paulo: Polis, 1978, p.52.

${ }^{21}$ Ely Souza Estrela. Os Sampauleiros. Cotidiano e Representações, São Paulo: Humanistas / EDUC / FAPESP, 2003.

${ }^{22}$ João Guimarães Rosa. "A hora e vez de Augusto Matraga" in Sagarana, Rio de Janeiro: Nova Fronteira, 2001, p.404. 


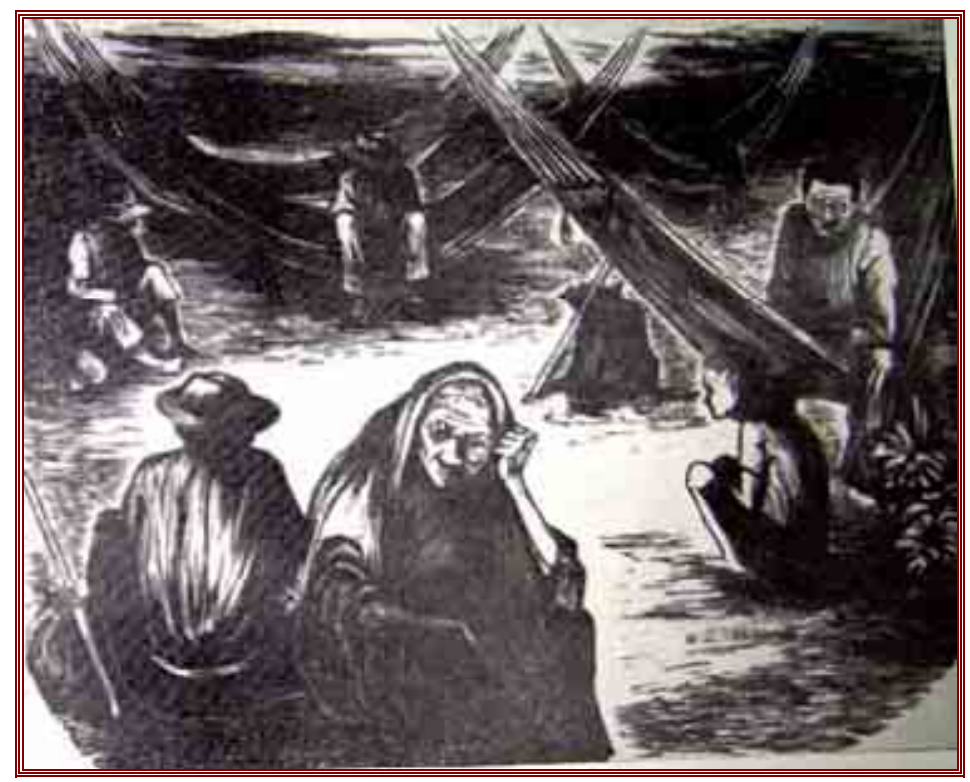

Ilustração 6 - "Pernoite", Série Retirantes.

Renina Katz, Revista Habitat, n $^{0}$ 29, abril de 1956.

Com o término da guerra, em 1945, a política imigratória foi revista em diversos países e a imigração voltou a crescer. ${ }^{23}$ No Brasil, o Decreto-lei $n^{\circ} 7967$ de 18 de setembro de 1945 passou a regulamentar a entrada de estrangeiros, impondo regras que estipulavam critérios para a seleção dos imigrantes desejáveis ao país. ${ }^{24}$ Essas regras - que nem sempre foram obedecidas pelas próprias autoridades brasileiras - eram passíveis de serem burladas e foram constantemente modificadas no decorrer das décadas de 50 e 60 . Isso fez com que a corrente imigratória para o Brasil tivesse semelhanças com uma roda da fortuna, o que enervava muitos técnicos no assunto e desesperava imigrantes que afligiam-se aguardando longamente por um visto. ${ }^{25}$

As sinuosidades encontradas na documentação ou no caminho, transpostas no intuito de alcançar São Paulo, continuaram a ser percorridas após a chegada. A caça não autorizada ou braconnage, que implicava na coleta do interdito, o

\footnotetext{
${ }^{23}$ Klein. op. cit., p. 61.

${ }^{24}$ Publicado no Diário Oficial em 6 de outubro de 1945. Para o Decreto-lei na íntegra consultar Coleção das Leis da República dos Estados Unidos do Brasil. Atos do Poder Executivo, vol. 7, out. a dez. de 1945, pp. 378-390. O Decreto-lei também foi publicado na Revista de Imigração e Colonização, vol. 4, dez. de 1945, pp. 445-455.

${ }^{25}$ Sobre a chegada de imigrantes no pós-guerra e as diferentes maneiras encontradas para burlar a legislação cf. Elena Pájaro Peres A Inexistência da Terra Firme. A Imigração Galega em São Paulo, 1946-1964, São Paulo: EDUSP/ IMESP/ FAPESP, 2003.
} 
détournement, ou seja, o desvio, o seqüestro, a reutilização do existente adaptando-o a um novo contexto, e, por fim, as virações praticadas pelos destituídos que habitavam a cidade, revestindo as situações experimentadas no dia a dia com flexibilidade, improviso e inconstância, impunham-se também aos seus novos moradores, diante da pretensa estabilidade "modernizadora" elegida e elogiada por vários setores como característica predominante da São Paulo dos anos $50 .^{26}$

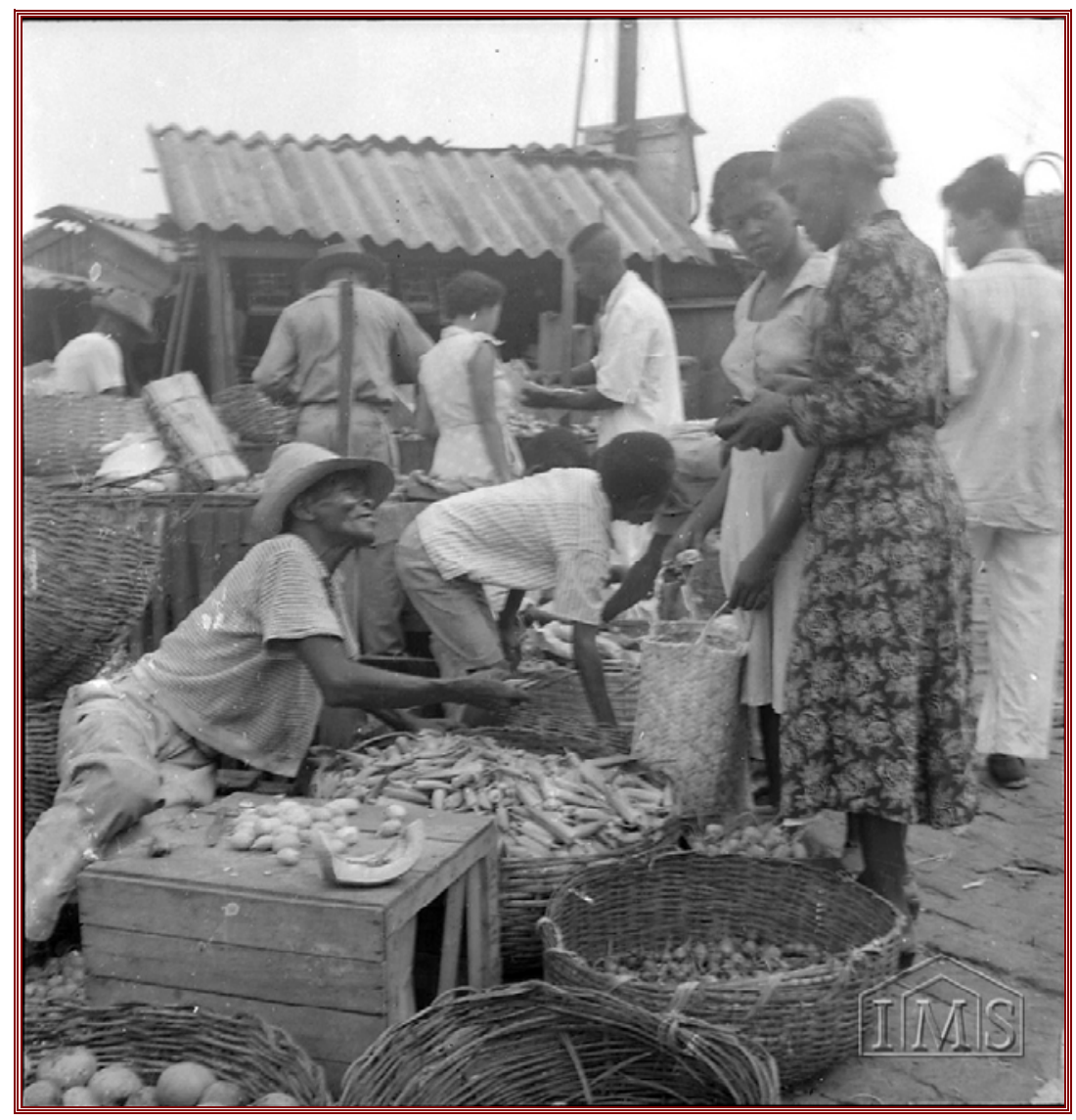

Imagem 7 - "Feira Livre", São Paulo, SP, 1953.

Alice Brill / Acervo Instituto Moreira Salles. Código: 011CXC3009.

\footnotetext{
${ }^{26} \mathrm{~A}$ noção de caça não autorizada ou braconnage está em Michel de Certeau. A Invenção do Cotidiano (Artes de Fazer), tradução de Ephraim Ferreira Alves, $4^{\text {a }}$ ed., Petrópolis: Vozes, 1999, p.38. O détournement aqui é entendido da maneira como foi proposto por Guy Debord e a Internacional Situacionista. Segundo Jappe, esse conceito foi teorizado por Debord e Wolman em 1956. Anselm Jappe, op. cit, p.84. Michel de Certeau também aborda a questão das "táticas desviacionistas" ou práticas cotidianas de détournement. Op. cit., p.89. Para uma melhor compreensão do emprego da noção de detournement por Michel de Certeau, ver a edição francesa, L'Invention du Quotidien, 1. Arts de Faire, $2^{\mathrm{a}}$ ed., Paris: Gallimard, 1990. Na edição brasileira detournement foi traduzido por dissimulação, o que não transmite o sentido mais apropriado do termo. Viração é um termo de conotação popular utilizado por vários autores, entre eles João Antonio e Plínio Marcos, para designar as atividades informais de seus personagens.
} 
Tentavam se aproveitar dos espaços de pouca vigilância, fazendo incursões periódicas às zonas de acesso proibido, utilizando, de maneira imprevista, lugares e produtos, procurando compartilhar de um jeito ou de outro da abundância. E, no dizer cristalino do escritor João Antonio, “(..) se tropicassem nas virações, ninguém lhes daria a mínima colher de chá (...)." Porque "A vida não costuma fazer graça pra ninguém." 27

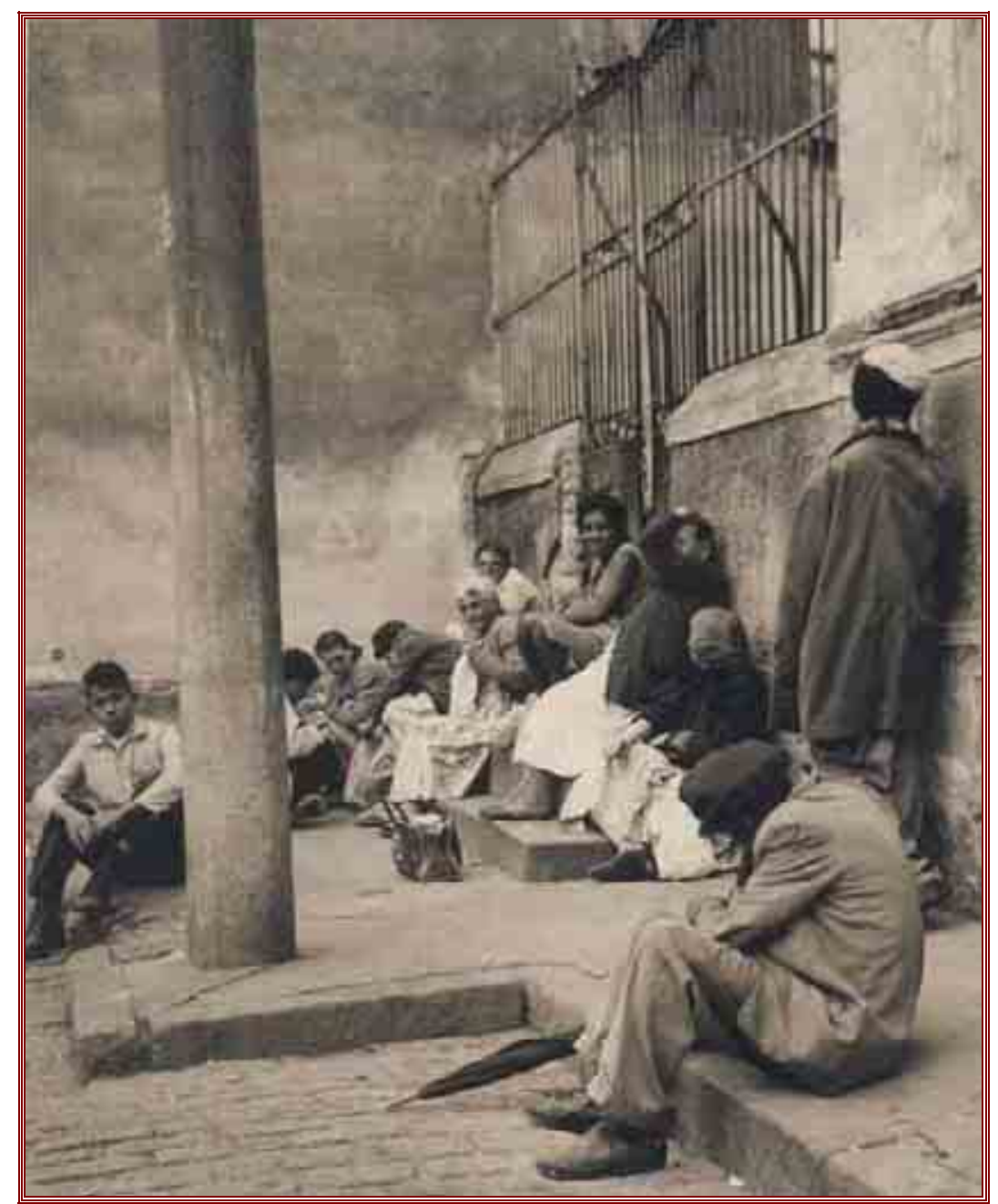

Imagem 8 - Albergue noturno em São Paulo, 1960.

Jornal Última Hora, 30/05/60 / Arquivo do Estado de São Paulo. Arquivos Especiais-Iconográfico.

Código: ICO-UH 1661-1662 - Assistência Social.

\footnotetext{
${ }^{27}$ João Antonio. "Malagueta, Perus e Bacanaço" in Malagueta, Perus e Bacanaço, São Paulo: Clube do Livro, 1987, p. 122. (1 $1^{\mathrm{a}}$ ed., 1963) e Leão-de-Chácara, São Paulo: Cosac \& Naif, 2002, p. 31. (1 ${ }^{\mathrm{a}}$ ed. 1975). Em toda sua obra, João Antonio utiliza constantemente as noções de viração e de virador referindo-se às práticas cotidianas dos malandros e também dos "merdunchos", definidos por ele como os zé-manés, os pés-dechinelo, os sem eira nem beira.
} 
O Brasil, nas duas décadas que se seguiram ao término da Segunda Guerra Mundial, especialmente em meados dos anos 50, procurou penetrar na senda do chamado desenvolvimento como forma de conter as tensões. ${ }^{28} \mathrm{Com}$ os investimentos norte-americanos, o país parecia ter encontrado seu rumo e aceitado sua suposta vocação para o crescimento. ${ }^{29}$

Arranha-céus despontavam em número cada vez maior em São Paulo, a cidade do progresso; o Rio de Janeiro dizia adeus ao status de capital, tendo já se transformado em centro de entretenimento turístico, especialmente conhecido pelas beldades cinematográficas que freqüentavam Copacabana; em Goiás, o cerrado começava a ser devastado para a implantação da cidade planejada a partir de $1957 . .^{30}$ Euforia, ansiedade e certeza de um grande futuro eram as sensações estampadas pela imprensa, lado a lado com o inconformismo diante da miséria "ainda" existente, evitando-se enxergar o quanto ela se incluía no chamado "desenvolvimento" e o quanto se ampliava a cada dia.

\footnotetext{
${ }^{28}$ Segundo Flávio Ribeiro, num relatório apresentado à CIA em 1954 (diretor Allen W. Dules), Rostow e Max Millikan propõem a industrialização e desenvolvimento dos países subdesenvolvidos com investimentos dos EUA. A nova estratégia tinha como fundamento a idéia de desenvolvimento oferecida como algo bom. Cf. Flávio Diniz Ribeiro. Para uma Crítica da Idéia de Desenvolvimento. Dissertação de mestrado apresentada ao Departamento de História da FFLCH-USP, 2002, pp. 152 e 158.

${ }^{29}$ Juscelino Kubitschek, presidente de 1956 a 1960, segundo Thomas Skidmore, apelou ao nacionalismo para justificar a necessidade de se tomar o caminho do desenvolvimento: "Era o 'destino' do Brasil tomar 'o caminho do desenvolvimento'. A solução para o subdesenvolvimento nacional, com todas as suas injustiças sociais e tensões políticas devia ser a industrialização urgente." Thomas Skidmore. Brasil: de Getúlio a Castelo, 10 a ed., Rio de Janeiro: Paz e Terra, 1992, p. 207.

${ }^{30}$ Sobre a transformação urbana da cidade de São Paulo nas décadas de 40 e 50, pode-se destacar, entre outros estudos: Benedito Lima de Toledo. São Paulo: Três Cidades em um Século, São Paulo: Duas Cidades, 1981; Maria Prosperi Meyer. Metrópole e Urbanismo. São Paulo Anos 50. Tese de doutoramento apresentada à FAU-USP, 1991, Sarah Feldman. Planejamento e Zoneamento. São Paulo, 1947-1972, São Paulo: EDUSP / FAPESP, 2005 e Segregações Espaciais Urbanas. A Territorialização da Prostituição Feminina em São Paulo, dissertação de mestrado apresentada à Faculdade de Arquitetura e Urbanismo da USP, 1989 e os estudos contemporâneos à época reunidos em Aroldo de Azevedo. A Cidade de São Paulo. Estudos de Geografia Urbana, 3 volumes, São Paulo: Companhia Editora Nacional, 1958.
} 


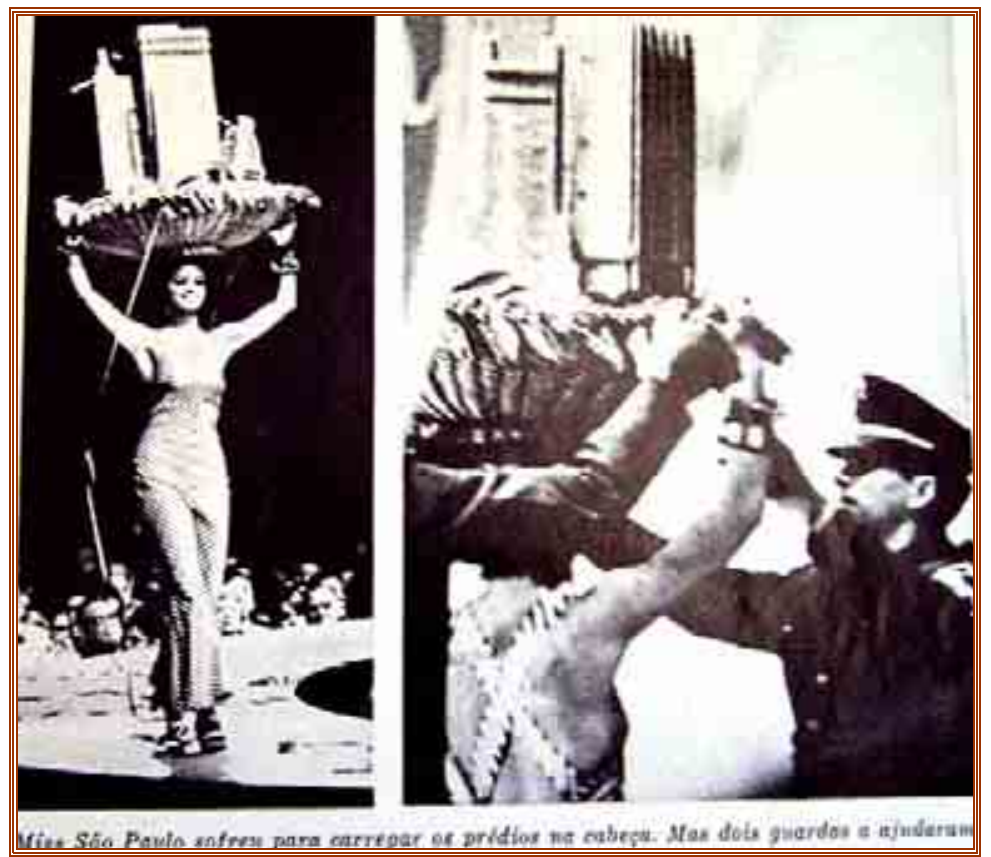

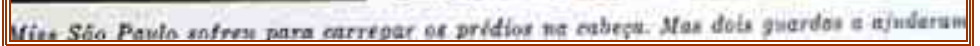

Imagem 9 - Miss São Paulo

Revista Realidade, $n^{\circ}$ 5, agosto de 1966.

Para a entrada definitiva do Brasil no que se previa como sendo definitivamente sua era urbana e industrial, o ponto que mais contava no discurso era velocidade aliada à eficiência técnica e planejamento. Nesse sentido, São Paulo despontava na imprensa como a cidade mais preparada para acelerar o fluxo de desenvolvimento que o país atravessava devido a sua grandiosidade e a riqueza concentrada por décadas. Era, por excelência, a cidade dos imigrantes e migrantes, o núcleo irradiador de oportunidades que vibrava na escala do desejo por uma existência melhor. Longe das estruturas econômica e socialmente estanques da vida rural, a capital parecia apontar, com seu dinamismo, para possibilidades que em outros cenários estavam terminantemente interditas. Era também, por esse motivo, o centro catalisador das tensões mais pungentes que poderiam se expandir em escala exponencial e que precisavam ser a todo o momento contidas. 


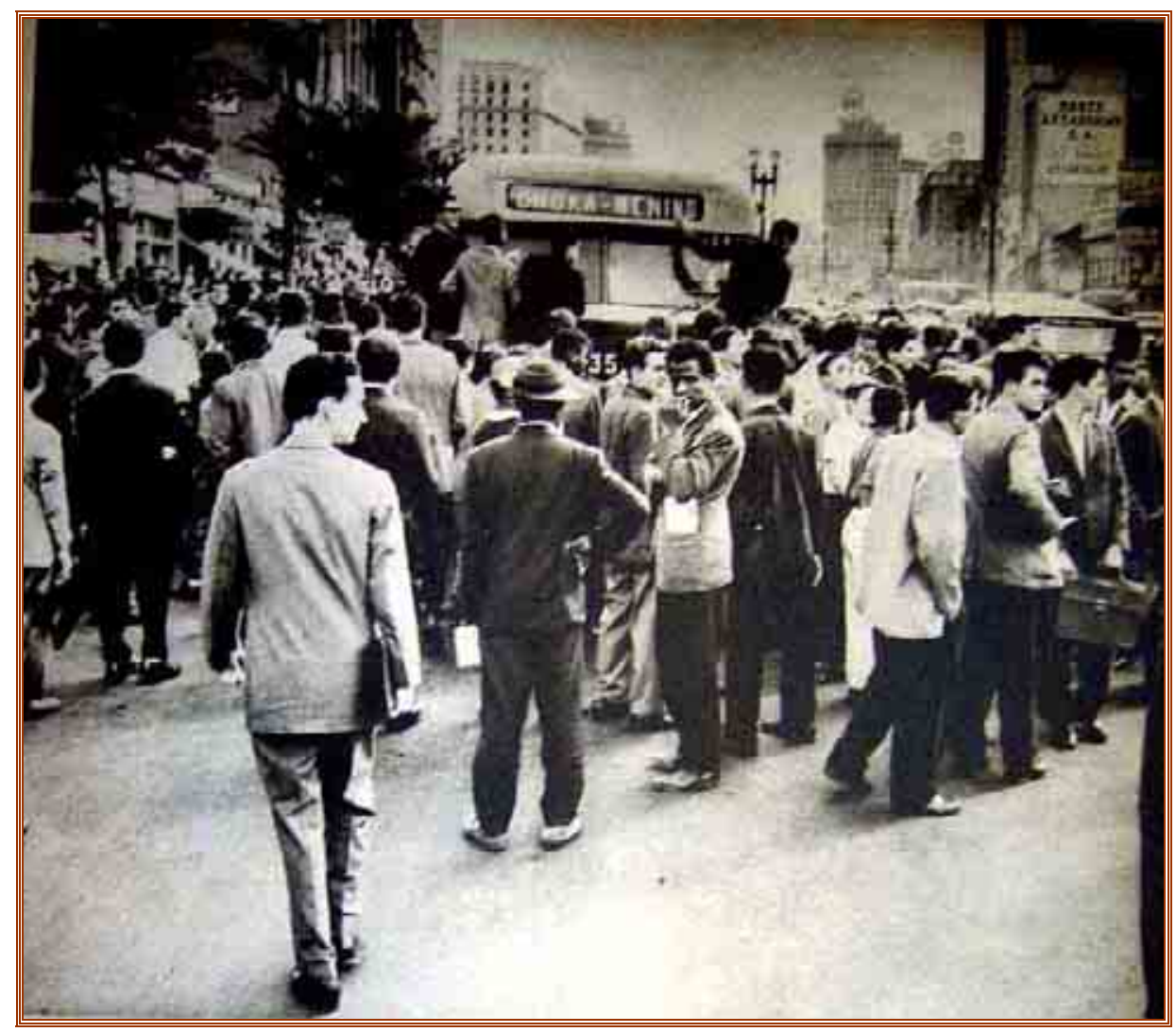

Imagem 10 - "Em São Paulo, o aumento das passagens de ônibus provocou o primeiro quebra-quebra da série. Foi este o mais violento de todos. Houve mortos." São Paulo. Revista Manchete, $\mathrm{n}^{\circ}$ 346, 6 de dezembro de 1958.

Manifestações espontâneas de revolta contra a abundância inacessível, despontaram em todo o país durante os anos 40, 50 e 60, materializando-se através de saques e quebra-quebras, sem nenhum tipo de organização. Em São Paulo, essas manifestações tomavam proporções assustadoras para as autoridades devido à rapidez de propagação e a incerteza da retomada do controle, entretanto extinguiam-se também com a mesma velocidade com que surgiam. ${ }^{31}$ A população acostumada a aproveitar todo tipo de sucata encontrada no caminho para construir um mundo, num estopim era também capaz de destruir completamente elementos que não reconhecia como seus.

Algumas dessas insurgências foram acompanhadas por greves de grandes proporções como a dos 300 mil em março de 1953, a dos 400 mil em 1957 e a dos

\footnotetext{
${ }^{31}$ Para Guy Debord, "A pilhagem é a resposta natural à sociedade da abundância, (...)." Cf. "OO declínio e a queda da economia espetacular mercantil”" in Situacionista. Teoria e Prática da Revolução, tradução Frances Wuillaume e Leo Vinicius, São Paulo: Conrad, 2002, p. p.123.
} 
700 mil em $1963 .^{32}$ Todas elas iniciadas a partir de uma insatisfação popular decorrente do aumento do custo de vida, especialmente a partir do final da década de 1940, e da impossibilidade da obtenção sequer de uma ínfima parte do que era incessantemente alardeado pela publicidade como imprescindível à felicidade familiar.

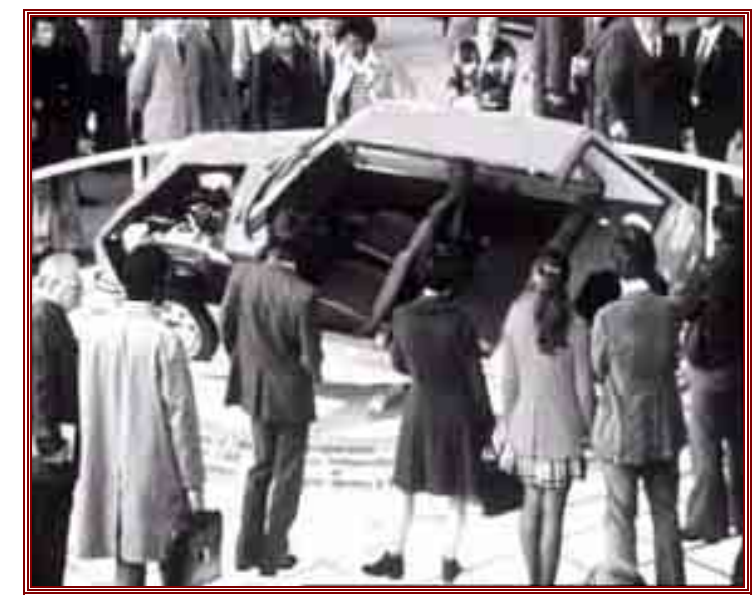

Imagem 11 - Cena do filme "La Societé du Spetacle", Paris, 1973. Guy Debord.

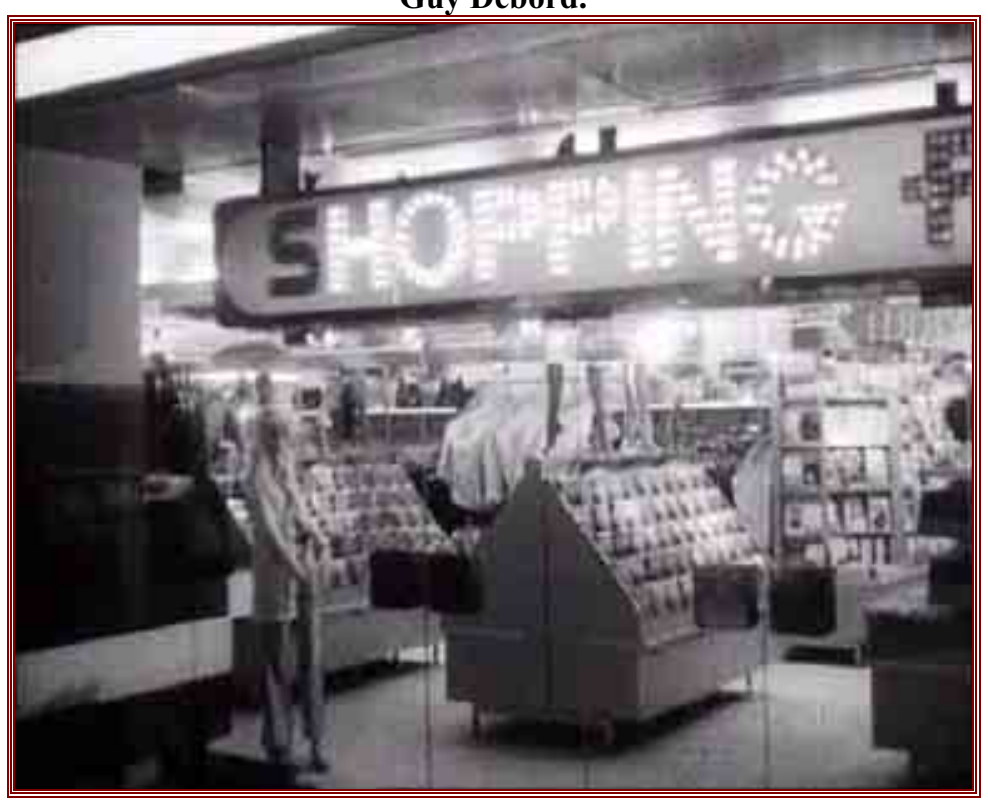

Imagem 12- Cena do filme "La Societé du Spetacle", Paris, 1973. Guy Debord.

\footnotetext{
${ }^{32}$ Maria do Socorro Abreu Lima A participação da mulher trabalhadora nos anos 50: buscando espaços, construindo identidades, dissertação de mestrado apresentada ao Departamento de História da FFLCH-USP, 1995. José Álvaro Moisés, op. cit..
} 
Simultaneamente à publicidade, a propaganda oficial induzia o olhar sobre a cidade. Na introdução do Guia Pitoresco e Turístico de São Paulo, publicado no início da década de 50 no governo de Adhemar de Barros, pode-se ler:

Um "Guia Pitoresco e Turístico de São Paulo" não poderia deixar de ser dinâmico, movimentado, vibrátil e conciso. Teria que dar, em poucas páginas, uma visão da terra, do homem e das suas conquistas, iniciativas e empreendimentos. É o que pretende esta publicação. Ela nada mais é do que São Paulo visto de relance, uma sucessão de imagens quase cinematográfica e num ritmo que é o próprio ritmo da vida moderna. ${ }^{33}$

O guia bilíngüe português-inglês entremeado de fotografias de Jean Manzon, exaltava a metrópole paulistana arriscando projeções quanto ao seu desenvolvimento futuro e de seus arredores. ${ }^{34}$ Sua capa, um desenho de Nico Rosso, era um convite aos que desejavam penetrar na cidade misteriosa da qual apenas pode-se ver a silhueta ao fundo, os portões abertos, a mala posta sem, contudo, ninguém para carregá-la.

\footnotetext{
${ }^{33}$ Guia Pitoresco e Turístico de São Paulo, São Paulo: Livraria Martins Editora, s.d.. Fotos de Jean Manzon, textos em português de José B. Almeida Júnior, textos em inglês de Maria Júlia Pinheiro Lopes.

${ }^{34}$ Idem. Sobre os álbuns fotográficos da cidade de São Paulo na década de 50 cf. Vânia Carneiro de Carvalho. Do indivíduo ao tipo: as imagens da (des) igualdade nos álbuns fotográficos da cidade de São Paulo na década de 50, dissertação de mestrado apresentada ao Departamento de História da FFLCH-USP, 1995. Vale lembrar que Jean Manzon havia trabalhado no DIP, Departamento de Imprensa e Propaganda do governo de Getúlio Vargas e também para Assis Chateaubriand na Revista O Cruzeiro. Cf. Fernando Morais. Chatô. $O$ Rei do Brasil, São Paulo: Companhia das Letras, 1994, p. 417.
} 


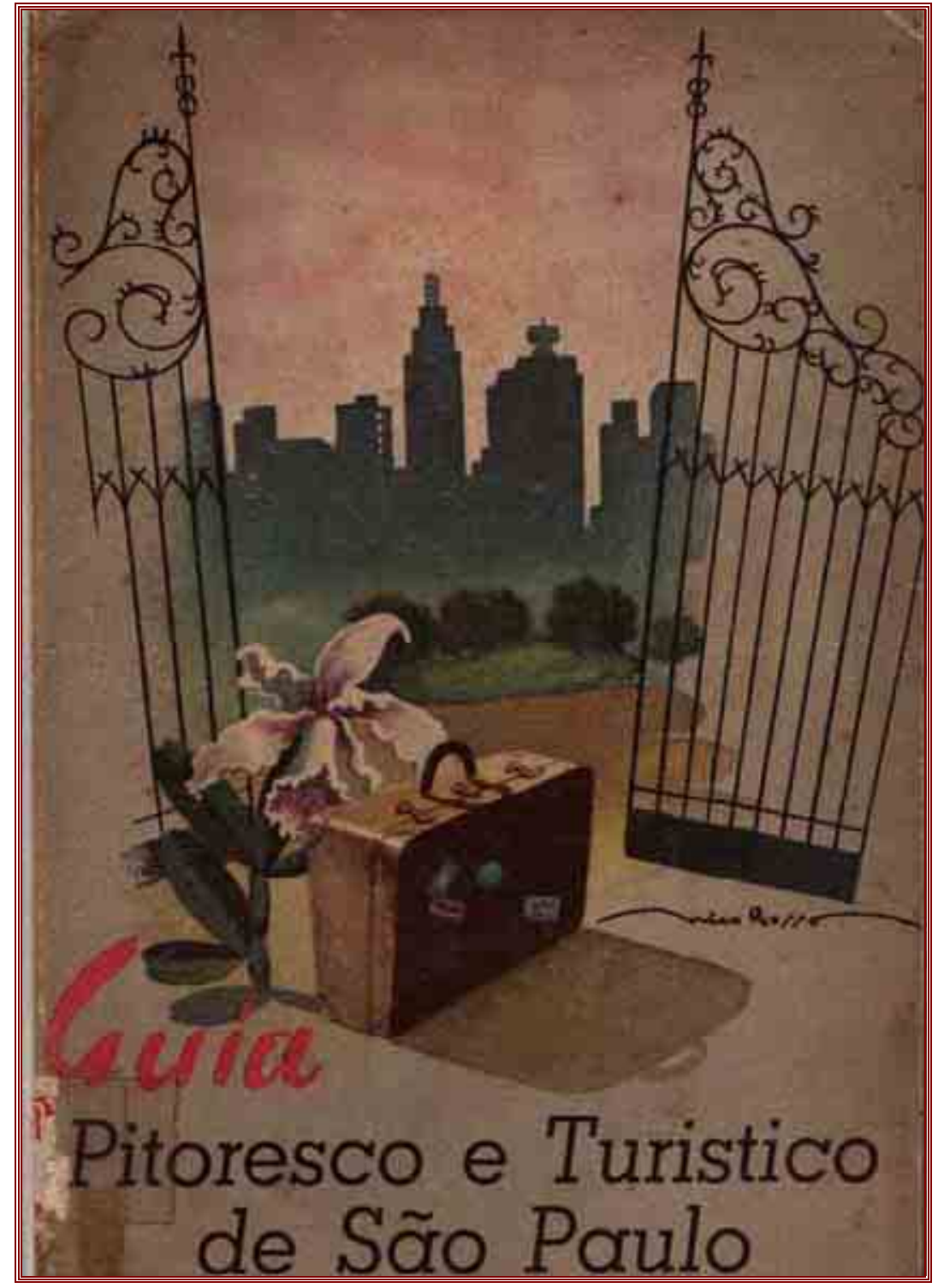

Imagem 13 - Guia Pitoresco e Turístico de São Paulo - capa

Arranha-céus, fluxo intenso de veículos, novas vias de circulação, viadutos, jardins cuidadosamente cultivados, foram ressaltados pela objetiva de Manzon com a intenção de demonstrar sumariamente o movimento ininterrupto da cidade arrojada, entrevista no guia por um rápido direcionamento do olhar. Um flash direto e iluminado que impede qualquer estabelecimento de vínculos afetivos com o espaço, qualquer possibilidade de sentir sua tessitura e, portanto, perceber suas 
zonas de sombreamento. As pessoas nas fotos estão ausentes, distantes ou em pose ensaiada, impedindo o contato.

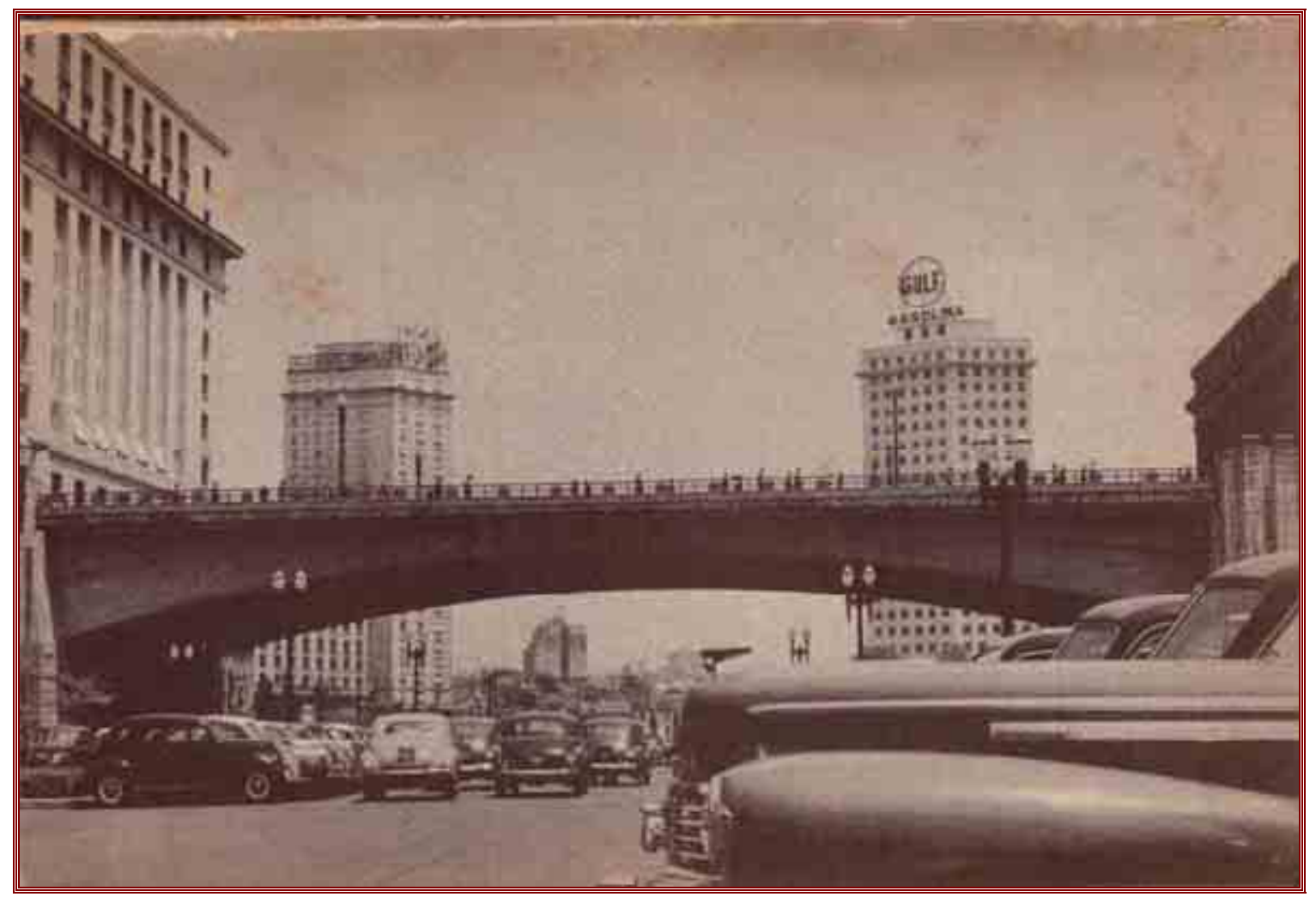

Imagem 14 - Vale do Anhangabaú e Viaduto do Chá.

Guia Pitoresco e Turístico de São Paulo

Onde, ainda no ano de 1900, existiam becos, vielas e casebres, rasgaramse grandes avenidas, surgindo, em meio do espanto geral, como obra de magia, suntuosos e magnificentes arranha-céus que buscam o infinito. E, no impulso dêste século de dinamismo, velocidade, luta e vibração, São Paulo prossegue em seu ritmo vertiginoso de progresso para cumprir o determinismo que o impele a ser uma das maiores capitais do mundo. ${ }^{35}$

O texto induz o leitor a pensar que tudo brotava por si próprio, como obra de magia, como fatalidade do destino. As estruturas semânticas e sintáticas, desveladas pela escolha dos verbos e da voz verbal, indicam que algo está indeterminado. O objeto da ação é mostrado como sujeito, enquanto o verdadeiro agente não é explicitado. Sabe-se que alguém construiu os arranha-céus e rasgou

\footnotetext{
${ }^{35}$ Guia Pitoresco e Turístico de São Paulo, op.cit..
} 
as avenidas, mas este alguém, mesmo existindo, está invisível. Tudo em São Paulo se construía como por encanto, surgia tão somente.

Construções para escritórios, condomínios, apartamentos, diariamente são iniciadas e diariamente concluídas. Ao próprio paulista é dado deparar surpresas: ontem aqui era um terreno vago, hoje é um belo e imponente arranha-céu. O poder inventivo de São Paulo supera a imaginação dos próprios poetas. ${ }^{36}$

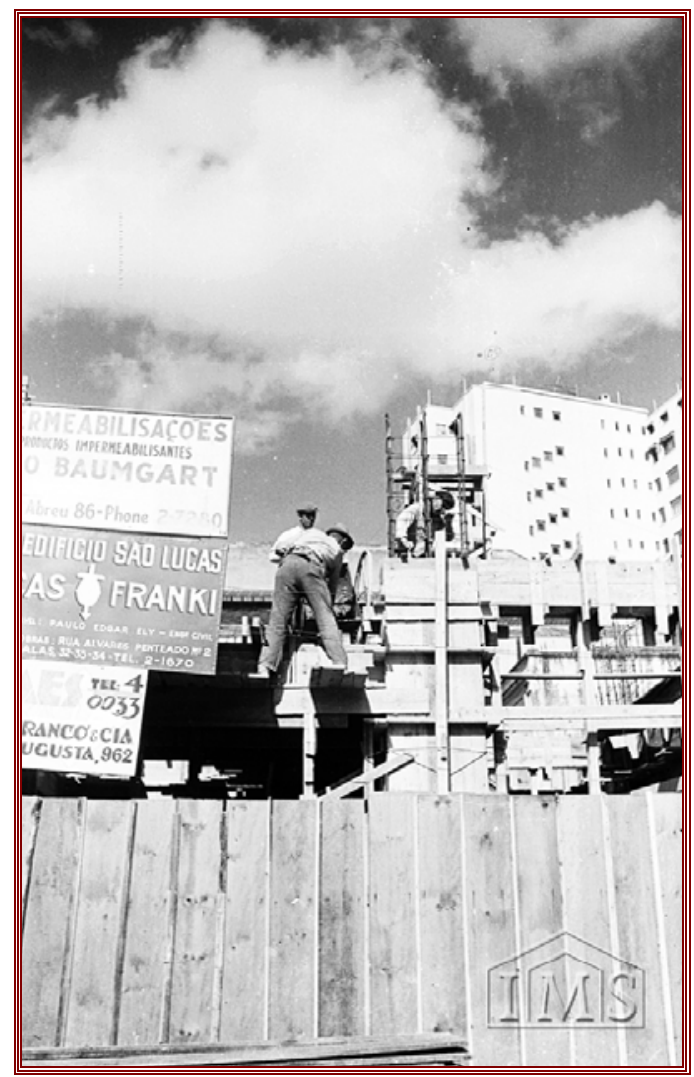

Imagem 15 - "Operários trabalhando em construção", São Paulo, SP, 1940. Hildegard Rosenthal / Acervo Instituto Moreira Salles. Código: 005HRP081.006

No horizonte se abria a possibilidade para novas e infindáveis construções, mas muitos dos terrenos vagos eram resultados de demolições que se tornaram cada vez mais constantes na cidade no decorrer do século $X X$ devido a supervalorização do solo urbano. ${ }^{37}$

\footnotetext{
${ }^{36}$ Guia Pitoresco e Turístico de São Paulo, op. cit..

37 " A cidade de São Paulo é um palimpsesto - um imenso pergaminho cuja escrita é raspada de tempos em tempos, para receber outra nova, de qualidade literária inferior no geral. Uma cidade reconstruída duas vezes sobre si mesma, no último século." Toledo., op. cit, p. 67. Sobre o orgulho existente na década de 50 em
} 


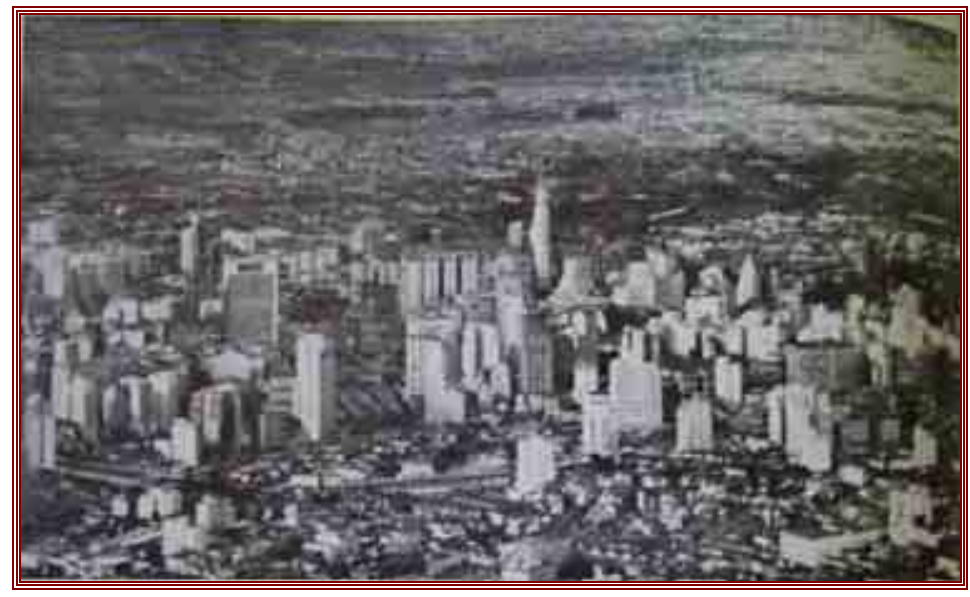

Imagem 16 - Panorâmica de São Paulo, Foto da Empresa Nacional de Fotografias Aéreas, 1950. Revista Paulistânia, n $^{\circ}$ 33, 1950.

E os espaços "mal aproveitados", segundo os padrões modernos, ou seja, vislumbrados como improdutivos, eram igualmente considerados devolutos e liberados para intervenções. Assim foram entendidas as várzeas até então ocupadas pelas derradeiras hortas, pelo futebol domingueiro, pelas lavadeiras e pelas favelas que começavam a crescer. ${ }^{38}$

Até há pouco, aquilo era do futebol da molecada. Indústrias querem surgir acompanhando a estrada de ferro, acompanhando tudo, provavelmente serão usinas de concreto. Várzea escura, breu. ${ }^{39}$

Contudo, nessas áreas percebidas como vazias a vida vibrava e projetava sua sombra. Um dos exemplos mais lancinantes dessa desconsideração pelo existente foi a construção do Parque do Ibirapuera.

Usando as palavras de Francisco Matarazzo Sobrinho - o Cicillo Matarazzo, seu grande idealizador - "o parque foi destinado a perpetuar a grandeza da data do IV Centenário de São Paulo."

demolir e reconstruir a cidade, cf. Carvalho. Do indivíduo ao tipo, op. cit.. Sobre as demolições constantes no centro da cidade, N. L. Muller. "A área central da cidade" in Aroldo de Azevedo. A Cidade de São Paulo. Estudos de Geografia Urbana, vol. III, São Paulo: Companhia Editora Nacional, 1958. p. 153.

${ }^{38} \mathrm{O}$ termo favela é utilizado neste trabalho seguindo a documentação do período que assim denominava os agrupamentos de habitações precárias, construídas com material improvisado em terrenos desocupados de particulares ou da prefeitura. O jornal $A$ Gazeta, no final dos anos 40, fez uma campanha contra o desalojamento dos clubes de várzea de seus campos para a construção do Parque do Ibirapuera. Cidade, Revista do Museu da Cidade de São Paulo, Ano 1, mar-1994, n 1, p.16. Sobre a ocupação recente da várzea do Tietê cf. Renato da Silveira Mendes. "Os bairros da zona Norte e os bairros orientais" in Aroldo de Azevedo. op. cit., vol. III, p. 189.

39 João Antonio. "Visita", Malagueta, Perus e Bacanaço, op. cit., p. 76. 
Já envolvido na realização das Bienais de Artes Plásticas, Cicillo assumiu também, em 1951, o ambicioso projeto de transformar os quase 2 milhões de metros quadrados de terreno baldio em um dos mais modernos e movimentados parques públicos do mundo. ${ }^{40}$

Como o texto bem o demonstra, o Ibirapuera foi considerado área devoluta, apesar das pessoas que ali moravam. E não eram poucas. Tem-se conhecimento que para a construção do parque houve a retirada de 204 famílias que moravam em 186 barracos localizados entre as ruas Manoel da Nóbrega e Abílio Soares. ${ }^{41}$

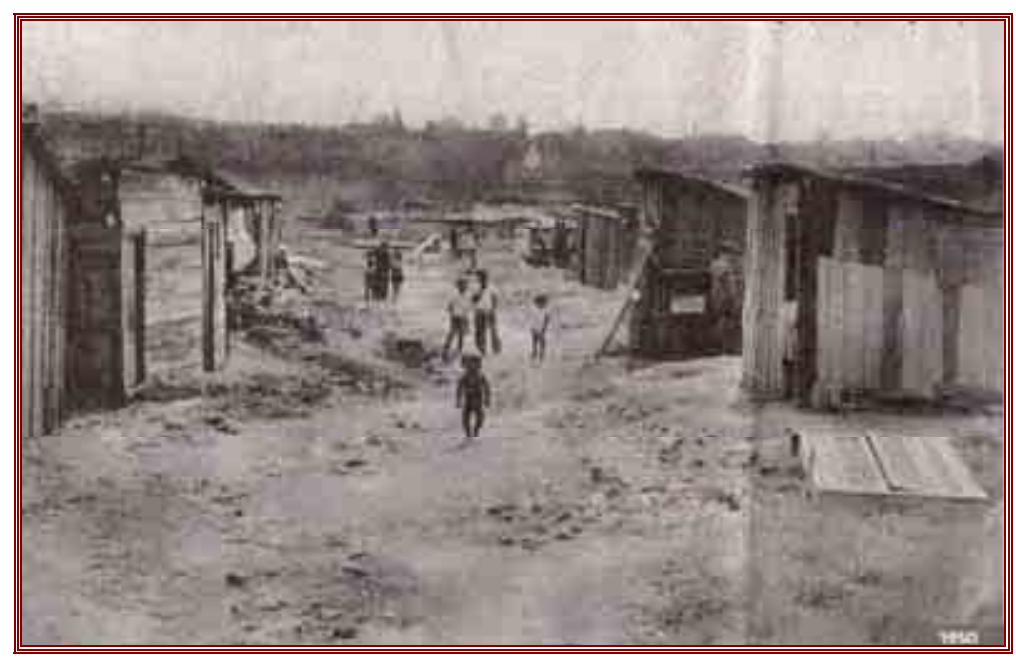

Imagem 17 - Favela na região do Ibirapuera, São Paulo, 1950. Sebastião Assis Pereira. Acervo Iconográfico da Prefeitura de São Paulo / O Estado de São Paulo, 7/05/06.

O pedido de desocupação foi feito em janeiro de 1952 pelo então presidente da recém constituída Comissão do IV Centenário, Ciccillo Matarazzo, ao prefeito de São Paulo, Armando de Arruda Pereira, e, com agilidade pouco comum na administração pública, atendido em outubro do mesmo ano. A existência dessa favela e o processo de liberação da área quase nunca são mencionados nos históricos do parque e, muito menos, são lembrados na

\footnotetext{
${ }^{40}$ Fátima Aparecida Fonseca e Jô Rostow. Cidade, Revista do Museu da Cidade de São Paulo, Ano 1, mar1994, no 1, p. 22.

${ }^{41}$ O termo barraco, de ampla utilização no período estudado, aqui designa as habitações improvisadas de ínfimas dimensões, construídas em madeira e todo tipo de material reciclado, geralmente agrupadas no que se designou como "favela". Ver a respeito da favela do Ibirapuera o livro de Nabil Bonduki Origens da Habitação Social no Brasil, $3^{a}$ ed., São Paulo: Estação Liberdade, 1998, p. 271.
} 
perpetuação da "grandeza da data do IV Centenário". ${ }^{42}$ Nem poderiam ser, se o que se buscava, como no Guia Pitoresco e Turístico, era a fixação de uma imagem positiva e ordenada da cidade. Entretanto, alguns incômodos sempre surgiam nessa trajetória de ordenação, especialmente quando, de maneira sinistra, alguém procurava mostrar com maior nitidez as nuances do que se ocultava à sombra do arranha-céu e muitas vezes no reflexo da vitrine.

A vila é bem mesquinha, rodeada de fábricas, dezenas de bares, três igrejas, um grupo escolar. O casario feio abriga mal gente feia, encardida, descorada. (...) As ruas com seus monturos, cães e esgotos, muitas vezes me davam crianças que saiam do grupo escolar. Não me agradavam aqueles pés no chão movendo corpinhos magros. Qualquer ignorante podia perceber que aquilo não estava certo, nem era vida que se desse aos meninos. ${ }^{43}$

João Antonio - contista que teve como seus interlocutores os desvalidos, os inconformados e os viradores que perambulavam pela cidade - foi um dos que souberam incomodar. Com o livro de estréia, em 1963, Malagueta, Perus e Bacanaço, iniciou seu trabalho literário marcado por contos de movimento ou deriva, em que os personagens vagueiam em busca de algo quase nunca definível, fugindo de uma realidade que se definia pelo alto teor de aprisionamento e por sua precariedade. Ele foi capaz de enxergar que junto aos "transeuntes que se dirigem para os grandes escritórios, as grandes lojas, onde vão ter na qualidade ou de clientes e fregueses, ou de funcionários e auxiliares" ${ }^{44}$, circulavam

\footnotetext{
${ }^{42}$ Em outubro de 1952 a Comissão do IV Centenário recebeu um relatório das "providências que vinham sendo tomadas no sentido de 'reaver inteiramente livre' o espaço destinado à construção do parque. A liberação constitui-se basicamente na remoção dos favelados do terreno situado entre as ruas Abilio Soares e Manoel da Nóbrega. O relatório informa que foram retirados desta área 186 barracos com 204 famílias. Destas remoções, cerca de 180 famílias foram para 'terrenos próprios' e 6 famílias foram encaminhadas para a favela do Canindé 'em próprio municipal, com fornecimento de madeiras, telhas, etc.' "Cf. Regina Maria Prosperi Meyer. Metrópole e Urbanismo. São Paulo Anos 50, 1991, pp. 60-1. Para Meyer, "esta sucessão de ocupações da área do Ibirapuera não aponta apenas para a substituição da penúria pelo equipamento moderno, da favela pela Feira Internacional destinada a exibir nossa incipiente mas promissora indústria. Esta remoção, que o relatório empenha-se em afirmar que foi 'executada sem incidentes de violência', aponta sobretudo para o agudizamento dos problemas de uso do solo urbano na metrópole paulistana que cumpria seu caminho inexorável de modernização.", Idem, p. 61. Sobre o mesmo assunto Maria Arminda Arruda comenta: "Assim, o projeto modernista do Ibirapuera desenvolveu-se no solo vivo da cidade industrial periférica ocupada por vastas zonas de moradia dos marginalizados, infensos a planejamentos dessa natureza.". Maria Arminda do Nascimento Arruda. Metrópole e Cultura. São Paulo no Meio Século XX. Bauru: EDUSC, 2001, p. 90.

${ }^{43}$ João Antonio. "Visita", Malagueta, Perus e Bacanaço, op. cit., p. 75.

${ }^{44}$ Guia Pitoresco e Turístico de São Paulo, op. cit..
} 
homens e mulheres especializados na conjugação do verbo "catar", em sua maioria adventícios, decididamente excluídos da prosperidade anunciada, mas não imunes à propaganda dessa prosperidade, entregues à própria astúcia para sobreviver e tentar aplacar sua febre, febre que era um impulso à deambulação e que, alternadamente, os dispunha e os indispunha a colaborar. Tratava-se do inconformismo nascido do encontro entre o desejo amplificado e a realidade minguada.

\section{(...) com a mesma febre marcharam. ${ }^{45}$}

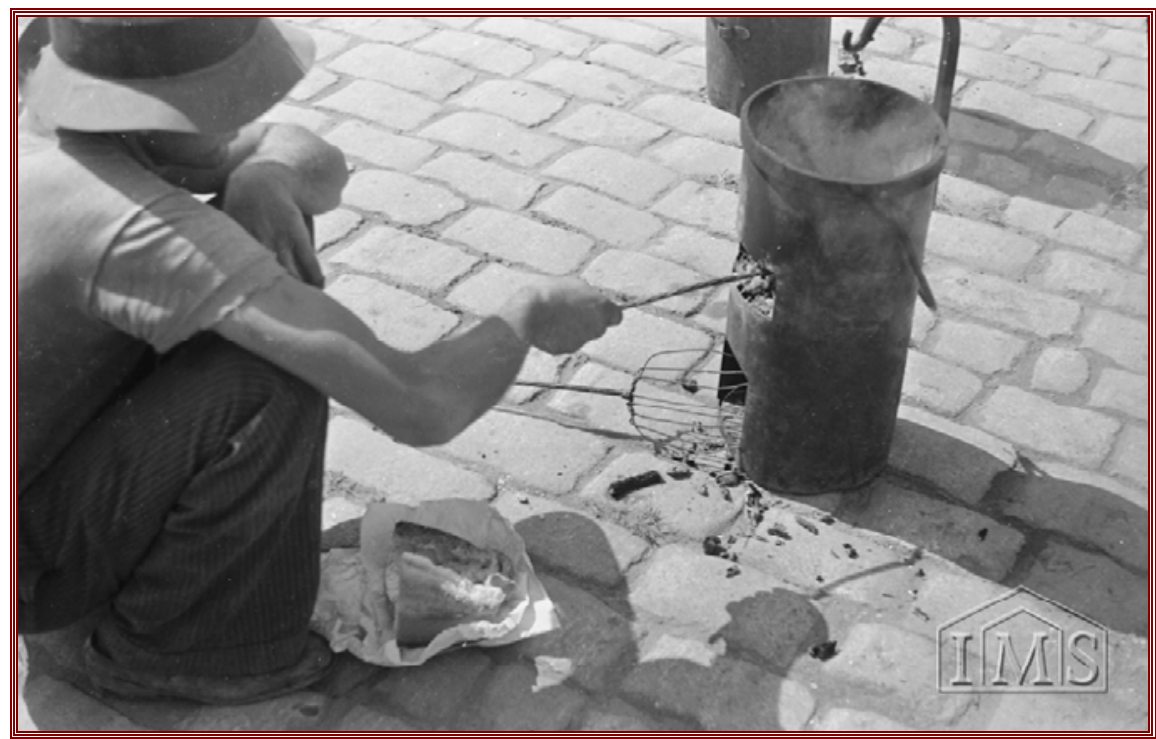

Imagem 18 - Homem e fogareiro, São Paulo, SP, 1940.

Hildegard Rosenthal / Acervo Instituto Moreira Salles. Código: 005HRP041.014

Carolina Maria de Jesus, moradora, desde 1947, da favela do Canindé, às margens do Rio Tietê, deixou também um registro dessa outra face de São Paulo.

\footnotetext{
45 João Antonio retrata a febre de Malagueta, Perus e Bacanaço, o desejo incontido em se dar bem, em se arrumar: "Malagueta, Perus e Bacanaço", op. cit., p. 129. Essa febre é a mesma que está presente nos personagens de West Side Story. Esse balé, encenado na Broadway na década de 50, trouxe à cena os destituídos e seus conflitos pela manutenção de pequenos territórios na periferia de Nova Iorque. Cf. Arthur Laurents. West Side Story, $11^{a}$ ed., New York: Dell Publishing Co., 1969. (1 ${ }^{\mathrm{a}}$ ed. 1965). Foi filmado em 1961, com a direção de Robert Wise e do coreógrafo Jerome Robbins.
} 
Em seu diário anotou as táticas e as experiências de uma catadora que vivia revirando o lixo enquanto sonhava em ser artista.

Quando eu vou na cidade tenho a impressão que estou no paraizo (sic). Acho sublime ver aquelas mulheres e crianças tão bem vestidas. Tão diferentes da favela. As casas com seus vasos de flores e côres variadas. Aquelas paisagens há de encantar os olhos dos visitantes de São Paulo, que ignoram que a cidade mais afamada da América do Sul está enferma. Com as suas úlceras. As favelas. ${ }^{46}$

Carolina escreveu seu diário em cadernos catados no lixo da cidade durante a década de 50 . Após várias tentativas frustradas de publicação de seus textos, conseguiu uma oportunidade ao mostrar seus manuscritos para o jornalista Audálio Dantas da revista O Cruzeiro. Seu primeiro livro, Quarto de Despejo, foi publicado em 1960 e a partir disso foi imensamente criticada por não ter, segundo os padrões econômicos que regem a sociedade, utilizado, de forma proveitosa, os recursos financeiros adquiridos com a vendagem das edições, "desperdiçando", segundo alguns, a chance que a vida oferecera-lhe. Entretanto, sua aparente ânsia pelo sucesso a qualquer preço, de que muitas vezes foi igualmente acusada, foi desmentida por seus descaminhos. ${ }^{47}$

Os três malandros da ficção de João Antonio - Malagueta, Perus e Bacanaço - ao caminharem pelo centro da cidade, numa madrugada de sábado, também viradores como Carolina "sabiam que depois dos luminosos a cidade Ihes daria restos e lixos. Só."48

\footnotetext{
${ }^{46}$ Carolina Maria de Jesus. Quarto de Despejo. Diário de uma Favelada, São Paulo: Francisco Alves, s.d., p. 84.

47 "Quem tem frio e fome, sobretudo quando já teve boas perspectivas, está marcado. Ele é um 'outsider' e, abstração feita de certos crimes capitais, a culpa mais grave é a de ser um 'outsider'." Theodor W. Adorno e Max Horkheimer. Dialética do Esclarecimento, tradução Guido Antonio de Almeida, Rio de Janeiro: Zahar, 1985, p. 140 .

48 João Antonio. "Malagueta, Perus e Bacanaço", op.cit., p. 128. O decreto municipal no 4407 de 15/10/59 determinava o fim da entrega de lixo nas chácaras por veículos da Limpeza Pública por um preço que não cobria as despesas. A partir daquela data o forno incinerador da Zona Norte queimaria parte dos resíduos antes descarregados nas chácaras. Os chacareiros deveriam buscar o lixo por conta própria se ainda o quisessem, sempre em veículos fechados ou cobertos.
} 


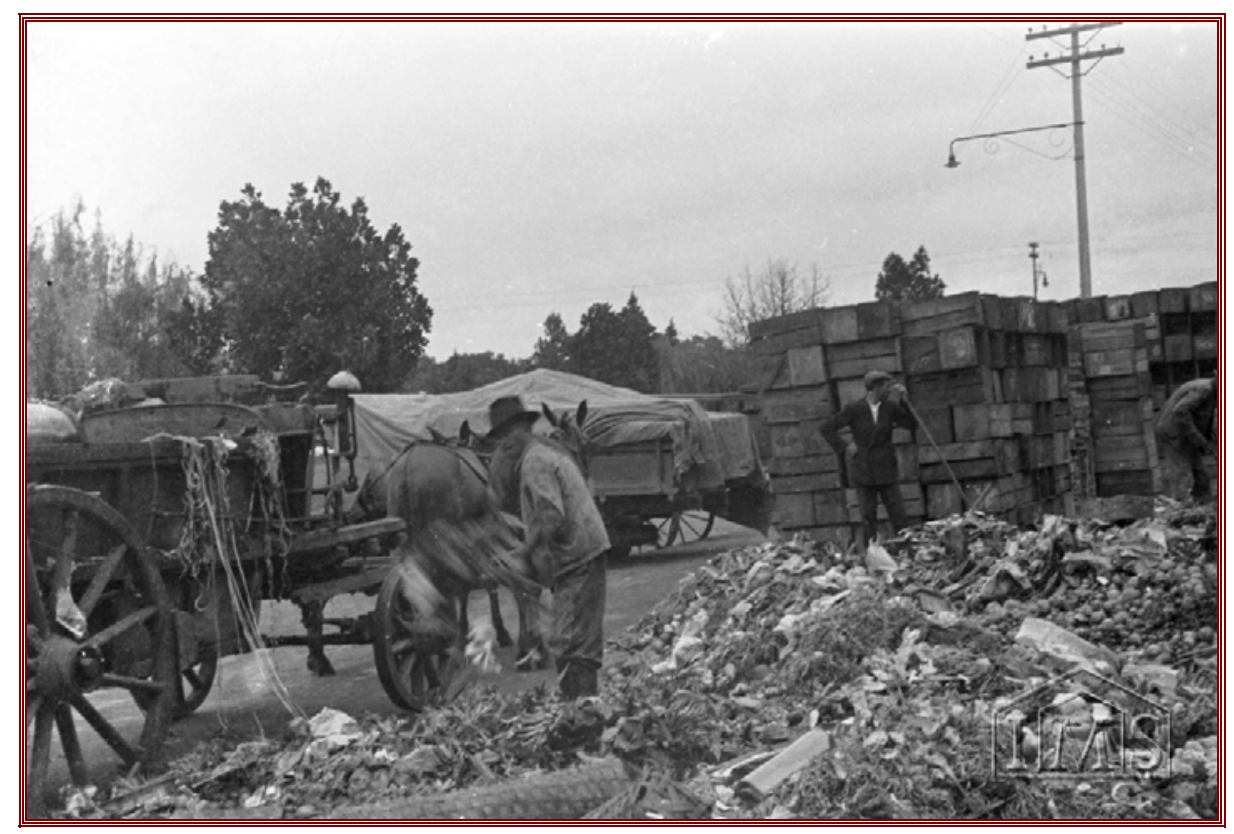

Imagem 19 - Homem colocando lixo em carroça, São Paulo, SP, 1940. Hildegard Rosenthal / Acervo Instituto Moreira Salles. Código: 005HRP041.025

Plínio Marcos, autor de Barrela (Peça em um Ato) (1958), Dois Perdidos numa Noite Suja (1966) e Navalha na Carne (1967), e uma série de outras peças, novelas e crônicas de grande repercussão, compostas por personagens sem paradeiro certo, migrantes, viradores, biscateiros, cheios de parangolés (astúcia), mostrou-nos um mundo de situações extremas.

Em sua primeira obra, Barrela, encenada uma única vez em 1959, imediatamente censurada pelo governo de Juscelino Kubitschek, permanecendo proibida por 21 anos, aparecem aqueles que buscaram a honra e tentaram aplacar a fome, vendo-se depois desonrados e famintos no cárcere, possuidores provisórios apenas de seu sono. A peça, feita por blocos de tensão, encaminhamentos entrópicos, seqüências de cheios e vazios que culminam em vértices que se dissipam na cena seguinte, provocando inesperados desfechos, traz em si uma palpitação incômoda surgida nos becos do Macuco, bairro 
portuário de Santos, em que Plínio Marcos cresceu e aprendeu a criar e a se criar. $^{49}$

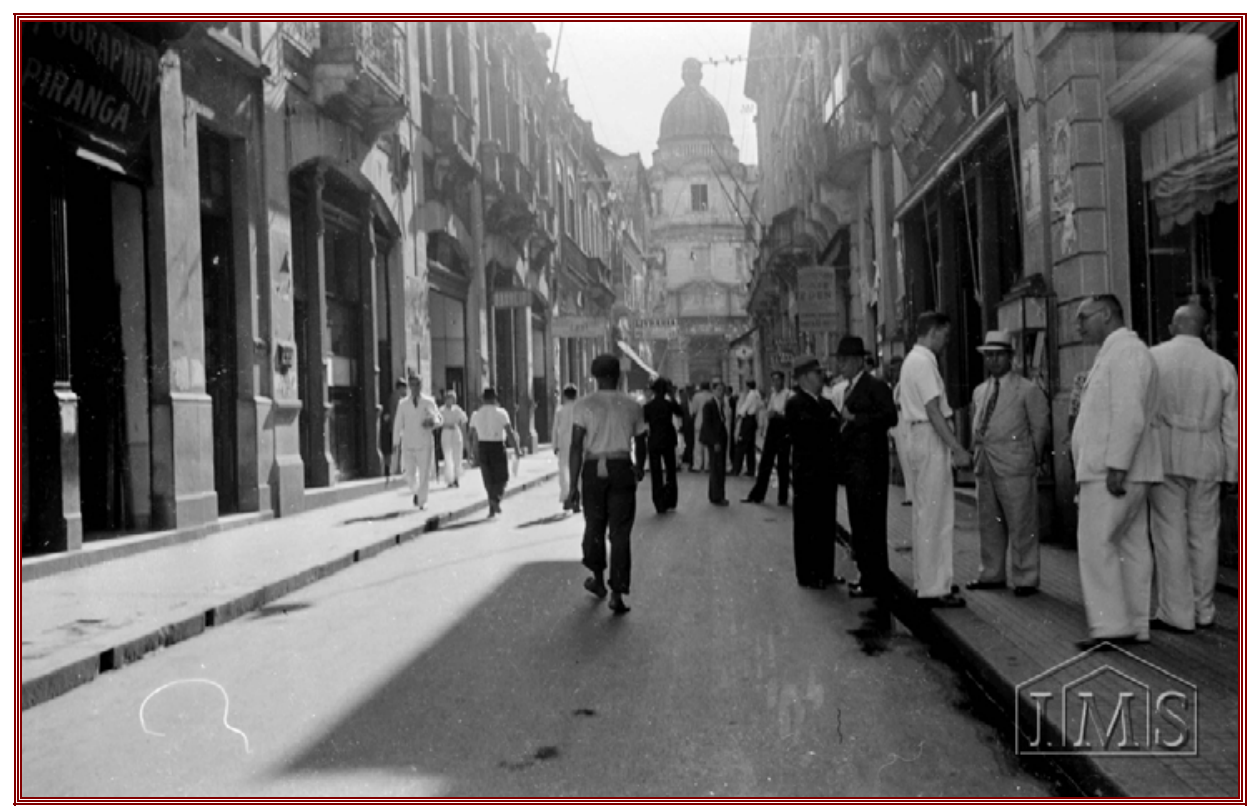

Imagem 20 - Homem descalço em rua central de Santos caminhando em direção ao edifício da Bolsa Oficial do Café, 1940. Hildegard Rosenthal / Acervo Instituto Moreira Salles. Código: 005HRP009.010.

Ozualdo Candeias, caminhoneiro e cineasta da Rua do Triumpho, parecia ter uma preferência pela temática da escassez e do desejo desesperado. Sendo isso já demonstrado em seu documentário sobre a pequenina cidade de Tambaú e seu padre milagreiro na década de 50 e depois manifestado fortemente em seu principal filme A Margem, de 1967, rodado às margens do Rio Tietê, transformadas em um lugar encantado, por onde perambulavam entidades diversas, seres despejados e erradios, à espera de um tempo melhor.

\footnotetext{
${ }^{49}$ Sobre a obra de Plínio Marcos ver ZANOTTO, Ilka Marinho. "Descida aos Infernos", prefácio de Plínio Marcos. Melhor Teatro, São Paulo: Graal, 2002, pp.7-20.
} 


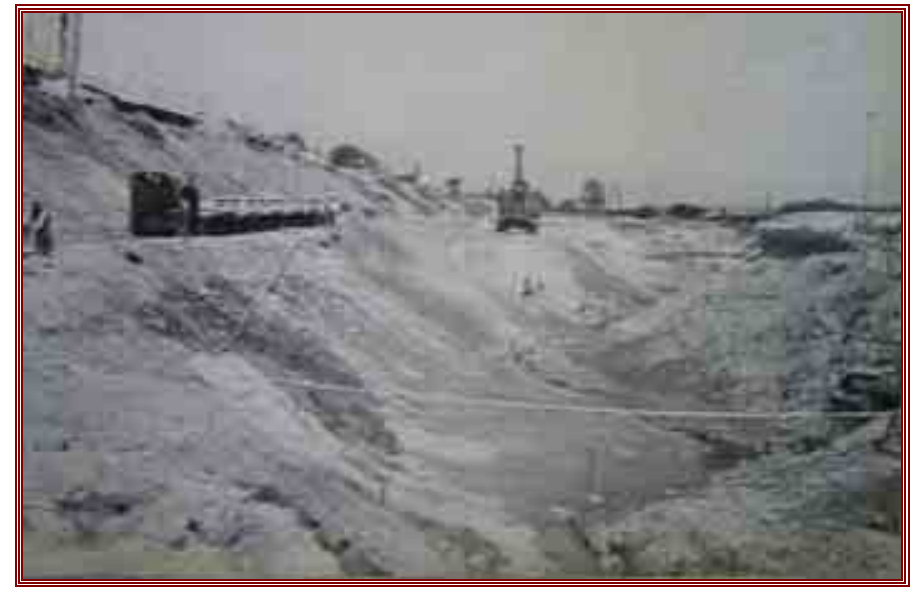

Imagem 21 - Canalização do Rio Tietê, São Paulo, SP, 1940. Revista Paulistânia, $n^{\circ}$ 9, out-dez, 1940.

O despejo de Candeias é o mesmo do qual nos fala Carolina. O despejo de quem foi expulso, daquele que foi jogado fora, mas também é o despejo que significa desembaraço, desenvoltura, vivacidade. Os despejados compunham a categoria dos denunciados como sem pejo, sem pudor, eram todos aqueles que foram lançados numa vida de moradias provisórias, ínfimas, indiscretas, e ao mesmo tempo os que estavam desimpedidos e totalmente soltos por não terem onde se fixar e por não aceitarem o papel que lhes era imposto pela sociedade, recusando inclusive curvar-se diante da caridade. 


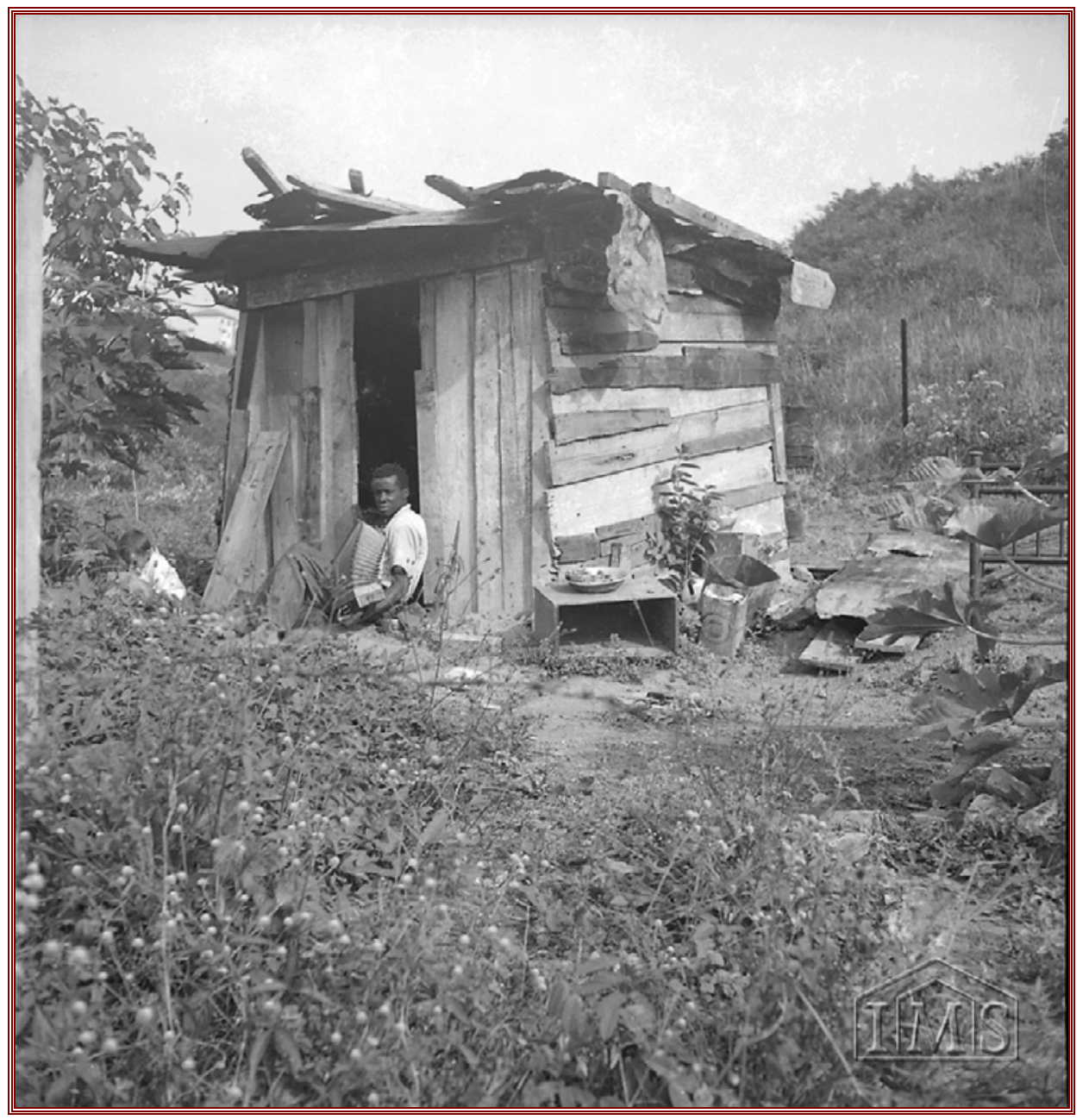

Imagem 22 - Homem com acordeão. São Paulo, SP. 1953.

Alice Brill / Acervo Instituto Moreira Salles. Código: 011CXB0707

A figura do despejado adquiriu um forte matiz a partir de 1942. Com a lei do inquilinato, promulgada nesse ano pelo governo federal, os aluguéis foram congelados e os proprietários incentivados, a partir de 1943, a demolir os imóveis de renda e construir prédios de maior vulto, inacessíveis para a maioria. Uma onda de despejos assolou a cidade de São Paulo. ${ }^{50}$

Simultaneamente aos arranha-céus em São Paulo, e em proporção muito maior, improvisavam-se favelas. Os cortiços que escaparam da demolição abarrotavam-se. Nos anos 50 , as pensões, casas de cômodos e hotéis baratos

\footnotetext{
${ }^{50}$ Sobre a lei do inquilinato e suas conseqüências cf. Nabil Bonduki, op. cit.. Em especial o capítulo "Favela e Periferia: a habitação produzida pelo morador".
} 
estavam com a lotação esgotada. Irrompiam, nos pontos mais afastados do centro, primórdios de bairros periféricos sem quaisquer recursos. ${ }^{51}$

A formação desses novos bairros interessava a muitos. Representava para as elites a possibilidade de manter em isolamento e em situação de invisibilidade uma população indesejada nas regiões centrais, além de significar lucro fácil para os especuladores através da venda de lotes clandestinos e, posteriormente, no investimento em transporte popular. Ajudava também a justificar os gastos públicos na ampliação da malha viária e a política de implementação da indústria automobilística. O sonho de todos era canalizado para a posse da casa própria, mesmo em um bairro distante, a construção de avenidas que dessem a impressão de agilizar o transporte e a disponibilidade no mercado de carros velozes, mesmo que inacessíveis.

De maneira inversa, as favelas, que vinham crescendo e se espalhando pela cidade, não eram condizentes com a lógica da especulação. ${ }^{52}$ Elas desvalorizavam os locais onde se instalavam, além de representarem uma imagem dissonante em relação ao imperativo do desenvolvimento econômico. Talvez isso explique o motivo pelo qual, no final da década de 50 , tomaram pulso tentativas de desfavelização como as do MUD, Movimento Universitário de Desfavelamento, que surgiu em 1961 a partir de uma campanha do Centro Acadêmico Oswaldo Cruz, da Faculdade de Medicina da Universidade de São Paulo. $^{53}$

\footnotetext{
${ }^{51}$ Sobre as favelas existentes nas várzeas cf. Renato da Silveira Mendes. "Os bairros da zona Norte e os bairros orientais" in Aroldo de Azevedo. op. cit., vol. III, p. 223. Segundo Azis Ab'Saber, o sistema de loteamentos populares se ampliou de repente, a partir de 1954. Cf. Cidade, Revista do Museu da Cidade de São Paulo, Ano 1, mar-1994, n ${ }^{\circ}$ 1, p. 5. Sobre a dificuldade em se encontrar uma vaga nas pensões para imigrantes em São Paulo, cf. Elena Pájaro Peres. A Inexistência da Terra Firme, op. cit., p.256.

${ }^{52}$ Segundo Meyer, Grostein, em A Cidade Clandestina, 1987, "examinando aspectos da evolução histórica do assentamento residencial das classes populares na metrópole paulista, mostra que o loteamento clandestino era na década de 50 um fato não apenas consolidado mas sobretuto institucionalizado." Eram vistos pelo poder público como uma alternativa " 'menos degradada' e sem dúvida, menos visivel, às temidas favelas." Apud Meyer, op. cit., p. 244.

${ }_{53}$ Nicolau Sevcenko afirma que por trás do imperativo do desenvolvimento econômico estavam "as iniciativas para a eliminação das imagens mais degradantes da pobreza urbana, como as tentativas de desfavelização, projetos de conjuntos habitacionais populares afastados para os arrabaldes, procurando impor às cidades brasileiras a racionalidade que lhes faltava desde as origens coloniais." "Mosaicos Movediços" in Pindorama Revisitada: cultura e sociedade em tempos de virada. São Paulo: Peirópolis, 2000, pp. 63-4.
} 
As favelas removidas por ação do MUD - com patrocínio de entidades diversas como bancos, o Jockey Club, o governo estadual e a prefeitura municipal, além de empresas multinacionais como a Willys Overland do Brasil, a General Eletric S.A., a Avon Cosméticos Ltda, a Singer Sewing Machine Co. e a Pfizer Corporation do Brasil, entre outras - foram a da Moóca, uma pequena parte da favela do Vergueiro e a do Tatuapé ou Nova Brasília. ${ }^{54}$

A inspiração para esse movimento veio da desocupação da favela do Canindé, onde morou Carolina e onde moravam cerca de mil pessoas. A retirada dos moradores foi levada adiante pela Divisão de Serviço Social da prefeitura em 1961. ${ }^{55}$ A partir desse ano, o prefeito Prestes Maia:

(...) precisou abrir um novo campo de ação social, mas por mera contingência: com a construção das marginais e das novas avenidas, tornou-se necessário remover as favelas ali instaladas, 'manchas da cidade', segundo o prefeito, e 'saco sem fundos em matéria de despesas, incontrolável por medidas comuns'. Essa ação era coordenada pela Divisão de Serviço Social do Município, e o prefeito, embora assumindo-a, não a considerava de sua alçada. ${ }^{56}$

A favela do Canindé, existente desde 1945, foi derrubada em doze meses e seus moradores foram distribuídos por 75 bairros da Grande São Paulo. ${ }^{57}$

\footnotetext{
${ }^{54}$ Tanaka, op. cit., pp. 21 e 23. A relação de empresas que fizeram donativos ao MUD está no Boletim Formativo e Informativo $n^{\circ} 4$, setembro de 1962, p.4, produzido pelo próprio Movimento. (Acervo LAP Laboratório de Estudos sobre Urbanização, Arquitetura e Preservação - FAU-USP)

55 "O que é o MUD?", op. cit..

${ }^{56}$ São Paulo (SP). Prefeitura. O Poder em São Paulo: história da administração pública da cidade, 15541992, Prefeitura do Município de São Paulo, São Paulo: Cortez, 1992, p. 83.

${ }^{57}$ Desfavelamento do Canindé, São Paulo: Divisão de Serviço Social, 1962.
} 


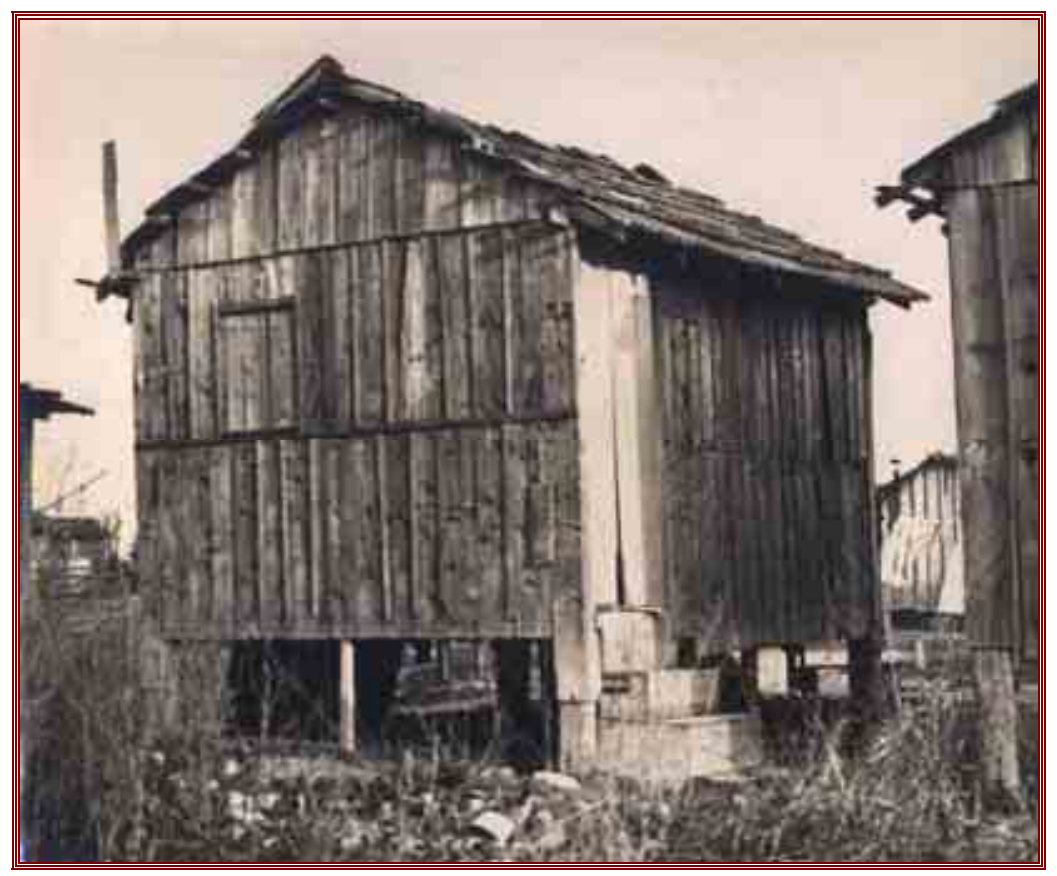

Imagem 23 - Barraco no 9 na favela do Canindé, onde Carolina morou com seus filhos de 1948 a 1960. Jornal Última Hora, 22/12/60 / Arquivo do Estado de São Paulo. Arquivos Especiais-Iconográfico.

Código: ICO-UH- 0369 - Carolina Maria de Jesus.

Mas, se num primeiro momento as favelas aparentemente não ofereciam oportunidade de exploração rendosa e aproveitamento em nenhum sentido - em contraposição aos cortiços, hotéis e bairros periféricos elas apenas causavam dispêndio à municipalidade e horror aos olhares mais requintados - essa impressão se desfaz quando se observa a situação mais atentamente. Eram elas um excelente campo para o exercício da caridade. Era delas que saía grande parte dos empregados domésticos e dos trabalhadores para a construção civil, motivo pelo qual os mais abastados receavam perder esse próximo e "rico manancial de mão-de-obra" barata. ${ }^{58}$

A construção civil era um dos setores que mais crescia na época e proviase desse manancial. Por outro lado, a substituição das favelas - com barracos feitos de restos de madeira, tijolos velhos, papelão, folhas de zinco e latas - por casas de alvenaria em bairros distantes, exigindo obras futuras de acesso e pavimentação, devia se mostrar como uma idéia tentadora para a auspiciosa

\footnotetext{
${ }^{58}$ Essa expressão encontra-se no documento citado acima, p. 15. Assim também pensava na época o prefeito do Rio de Janeiro, Sá Freire Alvim, que era a favor da urbanização das favelas da Zona Sul porque "se formos transferir essas pessoas para a Zona Norte as donas-de-casa ficarão sem empregada, cozinheira ou lavadeira." Revista Manchete, 20/12/1958, no 348. Em São Paulo a situação não era diferente.
} 
indústria de materiais de construção e, particularmente, para a de cimento que se nacionalizava no período. ${ }^{59}$

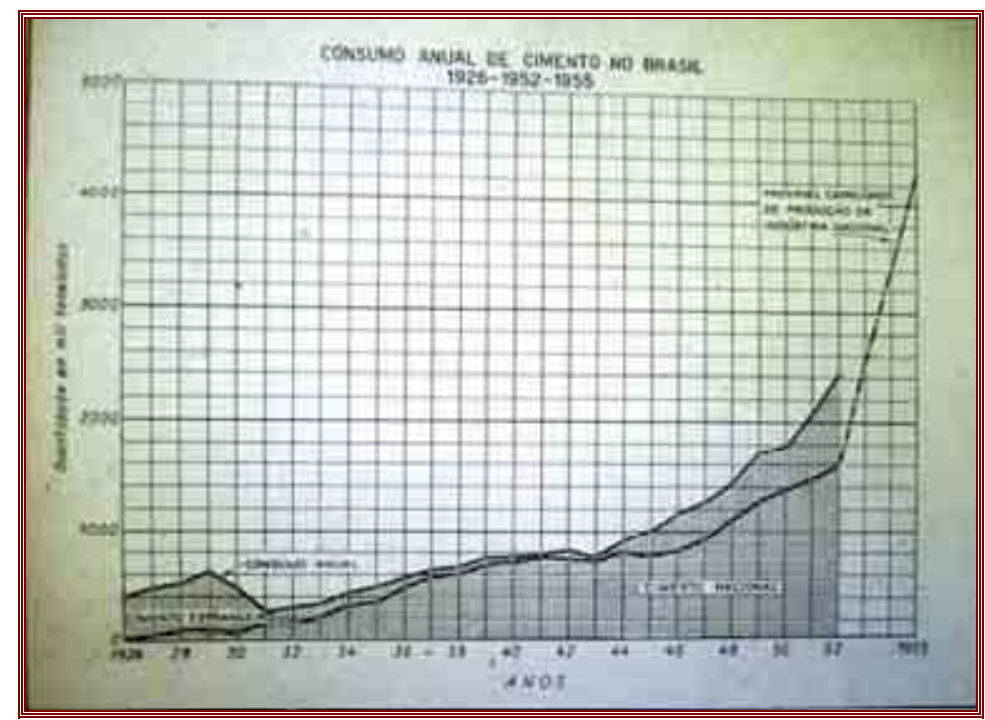

Imagem 24 - "O Brasil constrói o seu futuro"

Revista Manchete, $n^{\circ} 80,31 / 10 / 1953$.

Com o anseio de modernização da cidade, a arquitetura, aliada ao urbanismo, assumia a função de indicador do desenvolvimento apregoado. De arte eminentemente pública, passava a contar intensamente como investimento privado e índice de riqueza, modernidade e organização social. Dionísio, que preferia as modestas construções, parecia perder para Apolo, deus da luz e arquiteto por excelência. ${ }^{60}$

Seguindo essa tônica, vários projetos urbanísticos que visavam organizar racionalmente a cidade e, acima de tudo, valorizar áreas, tiveram destaque nesse período. Mas esse planejamento urbano, financiado pelo poder público e projetado por empresas particulares - muitas vezes internacionais como a do multimilionário Nelson Rockefeller - na maioria das vezes ficou apenas no papel e a cidade

\footnotetext{
59 Segundo reportagem da Revista Manchete de 31/10/1953 a lei de isenção para o cimento estrangeiro, assinada em situação de emergência quando faltava o produto no Brasil, perderia a validade em dezembro de 1953, o que era aguardado com ansiedade pelos donos do cimento nacional que previam lucros imensos para os próximos anos. Entre eles estava o industrial José Ermírio de Moraes, um dos principais articuladores da Comissão de Festejos do IV Centenário de São Paulo. "Sobre milhões de toneladas de cimento o Brasil constrói o seu futuro" in Revista Manchete, $\mathrm{n}^{\circ}$ 80, 31/10/53, pp.34-5.

${ }^{60}$ Marcel Detienne. Dioniso a Céu Aberto, Rio de Janeiro: Zahar, 1988, p. 80.
} 
continuou a seguir o padrão especulativo que o próprio mercado ditava, com a conivência governamental. ${ }^{61}$

O solo de São Paulo tornava-se, de forma mais acentuada, um grande negócio e a cidade transformava-se em mercadoria através de um acordo perverso entre a elite arrivista paulistana, seus interesses especulativos e as instâncias de poder, ocupadas por essa mesma elite. Os migrantes que afluíam para a cidade e, diferentemente do que foi afirmado por alguns autores, não fizeram acordo, foram empurrados pelas contingências. O crescimento se dava aos saltos, com pontos esparsos surgindo nos bairros periféricos e imensos vazios esperando valorização. ${ }^{62}$

O discurso hegemônico que previa a construção de uma cidade planificada, ordenada e voltada para o futuro, estava também presente na compreensão da cultura como atividade educativa e como referência de desenvolvimento. Não bastava erigir uma cidade moderna, era preciso treinar as pessoas para o uso e fruição convenientes da mesma e aceitação de seus princípios. Os projetos de desfavelização, como o MUD, por exemplo, tiveram como cerne essa preocupação educativa.

Nos objetivos da institucionalização da cultura estava previsto o controle das camadas populares, disciplinando as ações consideradas inadequadas, procurando substituí-las por comportamentos que pudessem denotar civilidade e desenvolvimento. ${ }^{63}$

\footnotetext{
${ }^{61}$ A empresa dirigida por Rockfeller era a International Basic Econonomic Corporation - IBEC, com sede em Nova York. Ela foi contratada por Linneu Prestes, prefeito indicado pelo governador Adhemar de Barros, em 1949, para realizar um estudo sobre as necessidades de São Paulo. Meyer, op. cit., p.72. Segundo Meyer, "em São Paulo uma desordem impenetrável desafiou os inúmeros e diversificados grupos de profissionais que sobre elas se debruçaram, muitas vezes com a modesta proposta de apenas atenuar o descompasso." Meyer, op. cit., p. 267.

${ }^{62}$ Discordo de Meyer quando afirma que "Na verdade o poder público municipal não possuía condições mínimas de estancar de forma radical, em pleno processo de desenvolvimento econômico, um procedimento que sem sombra de dúvida representava um acerto perverso entre a classe trabalhadora que afluia à metrópole em contingentes cada vez maiores, atraídas pela possibilidade de trabalho e de vida urbana, e os empreendedores imobiliários cada vez mais expostos às possibilidades de lucros." Meyer, op. cit., p. 247. O acordo passou longe da chamada "classe trabalhadora", firmando-se nas instâncias do poder político e econômico, que em muitas situações era formado pelos mesmos quadros dirigentes.

${ }^{63}$ Segundo Hannah Arendt, "Ao invés de ação, a sociedade espera de cada um dos seus membros um certo tipo de comportamento, impondo inúmeras e variadas regras, todas elas tendentes a 'normalizar' os seus membros, a fazê-los 'comportarem-se', abolir a ação espontânea ou a reação inusitada.” O indivíduo é equacionado à sua posição social. Op. cit, p. 50.
} 
A preocupação com a política cultural vinha do tempo da fundação do Departamento de Cultura de São Paulo, em 1935, por intelectuais ligados ao movimento modernista. Para esse grupo, o perigo da perda de uma pretensa identidade nacional era agravado pela presença maciça de imigrantes em São Paulo e deveria ser combatido pelo resgate das tradições luso-brasileiras, pela preservação do patrimônio arquitetônico colonial e pela tentativa de assimilação dos estrangeiros através da educação pedagogicamente orientada. ${ }^{64} \mathrm{O}$ medo da desnacionalização parecia por vezes se confundir com o medo da própria modernidade que se instalava insidiosamente em São Paulo. Procurava-se substituir uma modernidade desestabilizadora por uma modernidade comedida.

Os rumos da educação já eram discutidos, em 1920, por Amadeu Amaral, no discurso que proferiu sobre o ensino no Estado de São Paulo. Nessa ocasião ele comentava a importância da educação rural e suburbana para conter os arroubos de cultura apócrifa, não reconhecida pela elite que ele representava:

A criança mais bravia sofrerá nos seus rudes e esconsos pendores o contragolpe saudável de umas tantas noções de método, de asseio, de higiene e de disciplina. Conhecerá muitas outras crianças, tratará todos os dias com um professor ou uma professora: por aí lhe virão hábitos de sociabilidade e de urbanidade (....). ${ }^{65}$

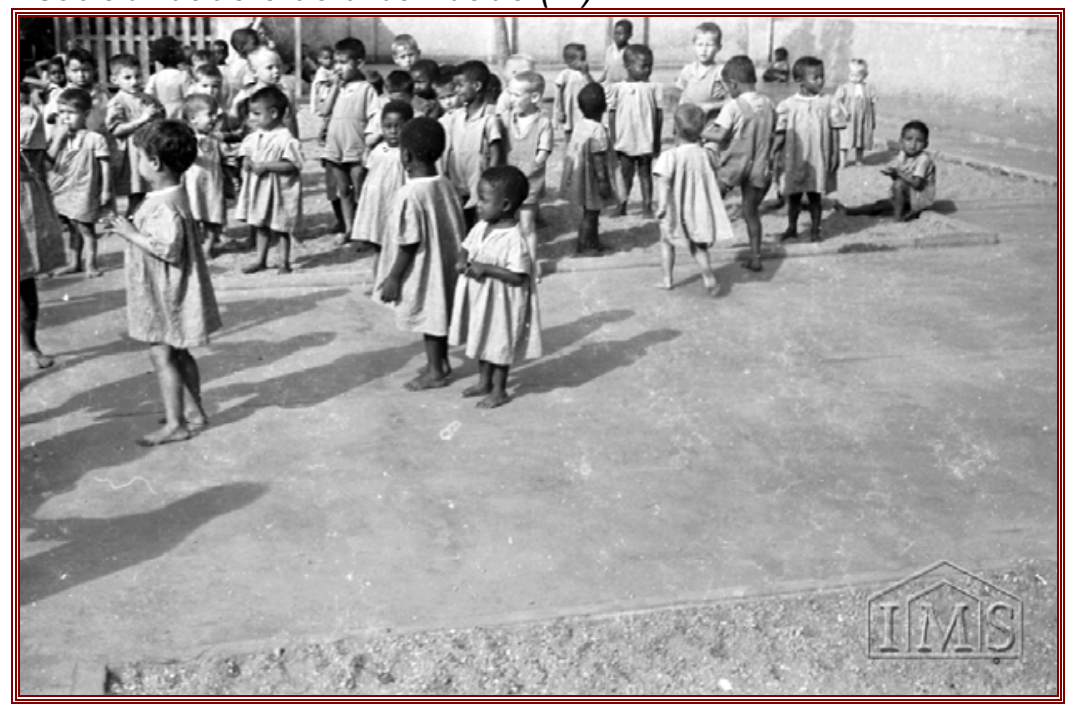

Imagem 25 - Crianças na escola, São Paulo, SP, 1940.

Hildegard Rosenthal / Acervo Instituto Moreira Salles. Código: 005HRP045.002

\footnotetext{
${ }^{64}$ Patricia Tavares Raffaini. Esculpindo a Cultura na Forma Brasil. O Departamento de Cultura de São Paulo (1935-1938), São Paulo: Humanitas, 2001.

${ }^{65}$ Amadeu Amaral. Política Humana, São Paulo: HUCITEC/Secretaria da Cultura, Ciência e Tecnologia, 1976, p. 97.
} 
Diante de um quadro para Amadeu Amaral a cada dia mais assustador com a chegada em massa de imigrantes, considerados por ele como usurpadores - acionava-se a educação como única e eficiente forma de assimilar os "alienígenas". Não era casual a proximidade das autoridades que atuavam no setor imigratório com os especialistas ligados às instituições educacionais. ${ }^{66}$ No pós-guerra, mais precisamente em 1952, foi criada a Campanha Nacional de Educação Rural, institucionalizada em 1956. ${ }^{67}$ Em 1957 o prefeito Adhemar de Barros, engrossando esse movimento em São Paulo, através de decreto, instituiu o Serviço de Assistência às Populações Rurais do Município. ${ }^{68}$

Esse serviço deveria promover assistência à família rural, investir na formação técnico-profissional dos agricultores e na educação "despertando-Ihes o sentimento de solidariedade e auxílio mútuo preparando-os, assim, para o cooperativismo." E também "tendo em vista a sua participação e efetiva integração na vida da comunidade rural a que pertencem(...)".

Estava previsto, pelo decreto municipal, a formação da juventude rural, o "aprimoramento do lar rural mediante associações femininas" e a recreação rural "mediante promoção de festas cívicas e sociais, esportes, etc, visando, além do mais, maior aproximação dos membros da comunidade".

Mais do que uma real preocupação com as condições de vida do agricultor, sabia-se que era do campo e dos sertões que emergiam candidatos à vida urbana. Os técnicos no assunto consideravam necessário intervir rapidamente nesses corpos e mentes, para que não trouxessem consigo, imiscuído em sua gestualidade, em sua razão ambivalente e até mesmo em seus genes, como se acreditava na época, o risco de desabamento da estrutura oca, extremamente sensível, montada nas metrópoles brasileiras. Essas estruturas emanavam um misto de modernidade e conservadorismo. Queriam-se fornecer parâmetros para

\footnotetext{
${ }^{66}$ Elena Pájaro Peres, op. cit..

${ }^{67}$ Iraíde Marques de Freitas Barreiro. "Educação modernizadora e educação de classe: o lazer, a cultura popular e o trabalho no período de Vargas e Juscelino" in Revista Brasileira de História, dossiê Brasil 19541964, São Paulo: ANPUH/Marco Zero, vol. 14, n² 27, 1994, pp. 149-165.

${ }^{68}$ Decreto Municipal no 3623 de 12/08/1957.
} 
que todos tivessem acesso à visão institucionalizada e consagrada da cultura e a consumissem enquanto espectadores, devidamente contidos.

Em São Paulo o espaço cultural, tal qual o espaço urbano, passou a ser visto como devoluto pela nova elite, formada em grande parte por imigrantes enriquecidos ou seus descendentes e remanescentes das antigas elites agrárias. Imaginava-se a existência de uma carência cultural que seria suprida mediante a execução de uma série de projetos que visavam colocar a população em contato com uma fração da arte e do pensamento moderno, em particular aquela que mais interessava enquanto elemento disciplinador. ${ }^{69}$ Mesmo assim, esse contato não deveria ser intenso, mas sim orientado, pois parecia óbvio que o chamado "povo" não saberia interpretar esse recheio cultural que lhe seria ofertado, nem tampouco se comportar diante das obras, daí a necessidade de mesclar cultura com didatismo. Segundo editorial da Revista Habitat, publicação trimestral do Museu de Arte de São Paulo, o semanário Arts de Paris tecera elogios ao MASP, por ser esse museu uma verdadeira escola. Os adultos eram considerados casos perdidos para a arte, mas os jovens:

Começam a compreender que no museu não se pode fumar, não se pode beber, que os cachorros não são admitidos, que não se pode entrar com atraso na conferências e concertos, com toda gentileza, faz-se observar que sair antes do fim duma reunião é malcriação, e muitas outras coisas pouco agradáveis para a maioria. ${ }^{70}$

Francisco Matarazzo Sobrinho, o Ciccillo, criador do MAM em 1949, da Bienal de Artes Plásticas em 1951, do Teatro Brasileiro de Comédia, da Vera Cruz, do Festival Internacional de Cinema em 1951, do Museu de Arqueologia e Etnologia da USP em 1964, da Bienal Internacional do Livro em 1969, organizador

\footnotetext{
${ }^{69}$ Para o demógrafo e urbanista Ernesto Mange, São Paulo começou a crescer vertiginosamente a partir de 55, 60. Em 1970 esse crescimento foi o máximo. "Em 70 e 80, porque começou a atrair gente não só do Estado de São Paulo, mas também do Brasil todo, centenas de milhares de pessoas que vinham desaculturadas, não só porque eram pobres, não é isso, vinham sem capital financeiro como também sem capital cultural para a vida urbana. Isso trouxe um desequilíbrio urbano em termos de serviços, empregos, transportes coletivos, as redes escolares, saúde, que foram completamente transbordados. Isso foi indo até os anos 70, 80. De uns 5, 7 anos para cá isso tem diminuido com a volta de alguns a seus estados de origem." Cidade, Revista do Museu da Cidade de São Paulo, Ano 1, mar-1994, nº 1, pp.20-21.

${ }^{70}$ Habitat, n 6, 1951, p.2.
} 
dos festejos do IV Centenário e responsável direto pela criação do Parque do Ibirapuera e do Balé do IV Centenário, dizia: "O que eu quero fazer é na rua... Nós, que constituímos uma certa elite, temos que instruir o povo". ${ }^{71}$

Lina Bo, diretora da revista Habitat anunciava, em seu primeiro número, que o Museu de Arte de São Paulo dirigia-se principalmente "à massa não formada, nem intelectual, nem preparada", com o intuito didático. ${ }^{72}$

A intencionalidade educativa, portanto, acabou por invadir os meios culturais de maneira institucionalizada, levando adiante o ideal de uma parcela do modernismo, fazendo renascer os anseios de grandeza existentes no período áureo dos presidentes paulistas. Os investimentos privados nesse setor cresceram durante os anos 50, com mecenas surgindo do seio da nova elite que, dessa maneira, procurava firmar sua posição na estrutura social, destacando-se por suas atuações beneméritas e pela sofisticação de suas escolhas culturais, promovendo suntosos eventos e fixando a cultura como entretenimento e mercadoria. ${ }^{73}$ Claro está que essas iniciativas não se fizeram sem o devido amparo governamental.

O dinheiro também vinha das famílias tradicionais que comemoravam em festas de alto requinte suas aquisições para o Museu de Arte de São Paulo. Numa dessas festas, Assis Chateaubriand, senador pelo Maranhão e pela Paraíba, embaixador do Brasil em Londres no final da década de 50 , um dos fundadores da Escola de Sociologia e Política e da Escola Superior de Propaganda e Marketing, criador do MASP em 1947, proprietário dos "Diários Associados", de fazendas, uma agência de publicidade, indústrias alimentícias e laboratórios farmacêuticos, introdutor da televisão no Brasil em 1950, imortal da Academia Brasileira de Letras, fez um discurso em que expôs os motivos que levavam, no seu entender, as elites ali presentes a participarem com doações:

\footnotetext{
${ }^{71}$ Cidade, Revista do Museu da Cidade de São Paulo, Ano 1, mar-1994, no 1, p. 24. Sobre a atuação de Ciccillo no cenário cultural paulista cf. Maria Arminda do Nascimento Arruda, op. cit.. Essa frase de Ciccillo lembra muito o comentário de Mário de Andrade em carta a Paulo Duarte na qual defendia o nivelamento cultural. A diferença estava em quem deveria atuar, para Mario era o governo: "Está claro, pois, que o nivelamento não poderá consistir em cortar o tope ensolarado das elites, mas em provocar com atividade o erguimento das partes que estão na sombra, pondo-as em condição de receber mais luz. Tarefa que compete aos governos. (...)." Apud Patricia Tavares Raffaini. op. cit., p. 103.

${ }^{72}$ Habitat, $\mathrm{n}^{\circ} 1,1950$, p. 17.

${ }^{73}$ Sobre o mecenato em São Paulo na década de 50 cf. Arruda, op. cit. .
} 
De onde, entretanto, tirar recursos para levar a arte ao povo? Formulam-se queixas contra a família voraz dos tubarões, mas conosco eles têm sido dóceis e flexíveis. Talvez porque Ihes falemos pedagogicamente de seus deveres coletivos, eles costumam ouvir-nos. Acentuamos os riscos que corre sua estirpe numa era que é o século dos assalariados e dos monopólios estatais. E eles sabem que, na verdade, o que fazem conosco são seguros de vida.

Estamos fornecendo salva-vidas à nossa burguesia. ${ }^{74}$

Percebe-se no senso irônico de Chateaubriand uma nítida consciência do uso da cultura enquanto instrumento de conformismo e de manutenção da ordem capitalista. Talvez parecesse interessante, por outro lado, para as "nobres famílias paulistas" tentar apagar definitivamente a sombra que poderia ligar sua estrondosa riqueza à estrutura torpe da escravidão e à descabida exploração dos trabalhadores migrantes e imigrantes. Investir parte dessa riqueza em obras de arte que poderiam, dentro dos limites disciplinados dos museus, através de um olhar pedagogicamente orientado, ensinar o "povo" a venerar os "benfeitores", tinha um encanto sublime. Dessa forma, a coleção do MASP, por exemplo, adquire um sentido histórico particular. Por trás de cada obra de arte pode-se entrever a sombra da espoliação que as acompanha em seus nichos, a segunda sombra do conto de Coelho Neto, aquela da qual as "nobres famílias paulistas" tentaram em vão se livrar. Espoliação também atrozmente presente em cada símbolo do progresso paulista, em todos seus arranha-céus, viadutos e novas avenidas.

\footnotetext{
${ }^{74}$ Fernando Morais. Op. cit., p. 483. Na revista Habitat $n^{\circ} 6$ de 1951, Chateaubriand elogia Walter Moreira Salles pela recepção dada para receber as novas aquisições do MASP.
} 


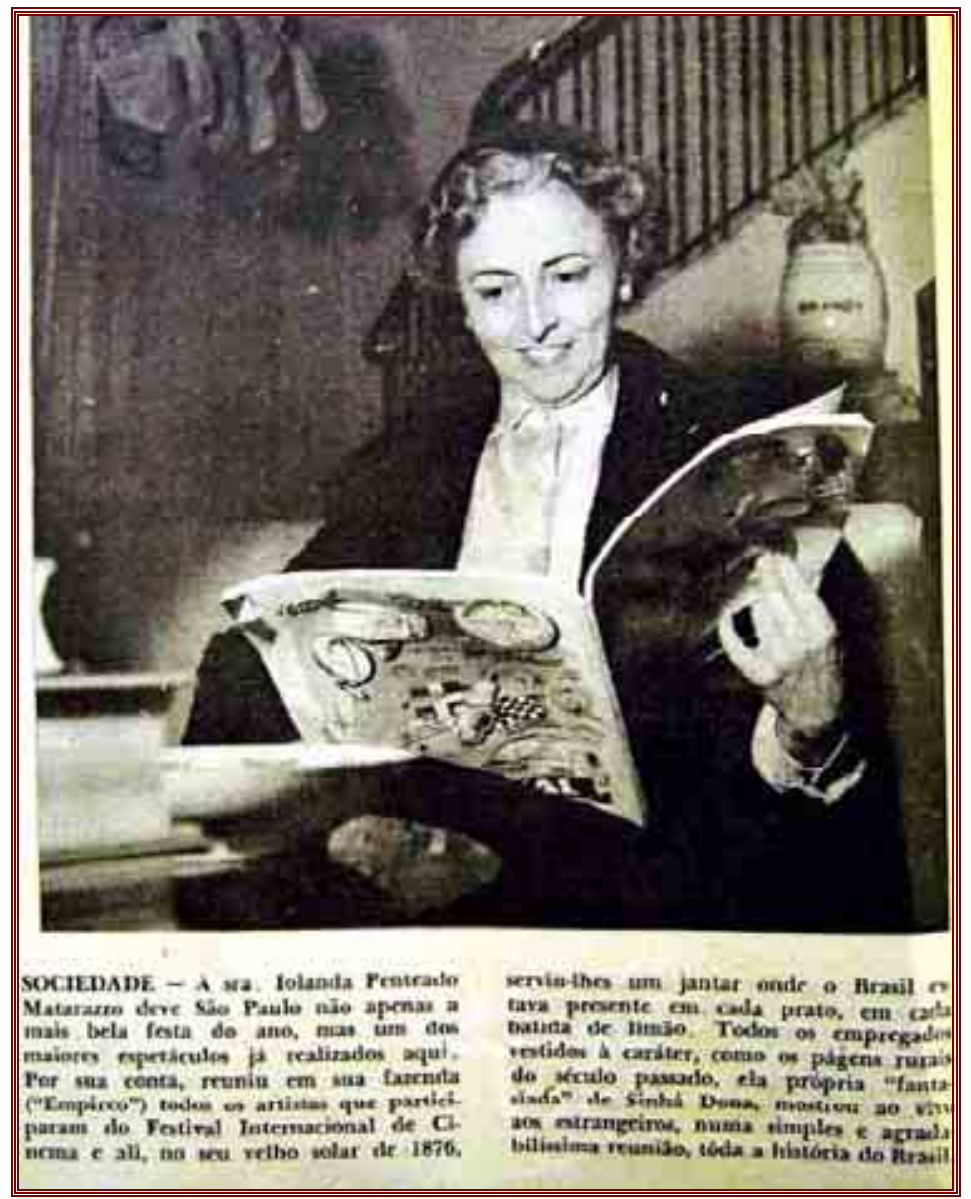

Imagem 26 - Iolanda Penteado Matarazzo, esposa de Ciccillo, reuniu artistas em seu solar de 1876. Revista Manchete, jan., 1955.

Os empresários "ilustrados" dos anos 50, como Ciccillo Matarazzo e Assis Chateaubriand, apesar de suas diferentes maneiras de atuação, foram figuras ímpares no período por sua visão amplificada das possibilidades abertas pela articulação entre cultura e poder. Não agiam na cena cultural, mas tentavam comandar essa cena, através de conglomerados midiáticos dos quais os museus eram uma parte, não desprezando suas singularidades. ${ }^{75}$ Provavelmente esse comando se dava com uma parcela de frustração, uma vez que suas metas nunca foram integralmente alcançadas, apesar do dispêndio a que se entregavam -

\footnotetext{
${ }^{75}$ A diferença entre ação e comando está em Hannah Arendt $A$ Condição Humana, op. cit.. É preciso matizar a atuação dos dois mecenas, que tinham estilos diferentes. Ciccillo criticando Chateaubriand afirmou: “ ' $O$ que ele queria fazer para um grupo de iniciados e privilegiados, eu desejava fazer para o povo, para o homem da rua'..." Arruda, op. cit., p. 289. Chateaubriand não parecia ter opinião muito diferente sobre Ciccillo. A inimizade de Chateaubriand com a família Matarazzo vinha de longa data. Cf. Morais, op. cit..
} 
gastando grande parte do tempo que tinham obtido dos trabalhadores de suas empresas - e dos recursos que conseguiam angariar em prol de suas campanhas culturais. ${ }^{76}$ Conseguiram projeção internacional com suas iniciativas, mas não tiveram o controle sobre todos os campos da cultura como almejavam e viram suas propostas despencarem com o enrijecimento do poder em todas as instâncias a partir de 1964.

A inspiração maior desses empresários provinha do exemplo de Nelson Rockefeller, dono da Standard Oil Company, presidente do MOMA, conselheiro do Metropolitam Museum em Nova York e, por fim, governador desse Estado. Rockefeller viajava constantemente ao Brasil desde 1942, representando no início o Office of the Coordinator of Inter-American Affairs, dirigido por ele, e depois como assistente do secretário de Estado para Assuntos Latino-Americanos. ${ }^{77}$ Mais do que inspiração pode-se pensar em orientação direta. ${ }^{78}$

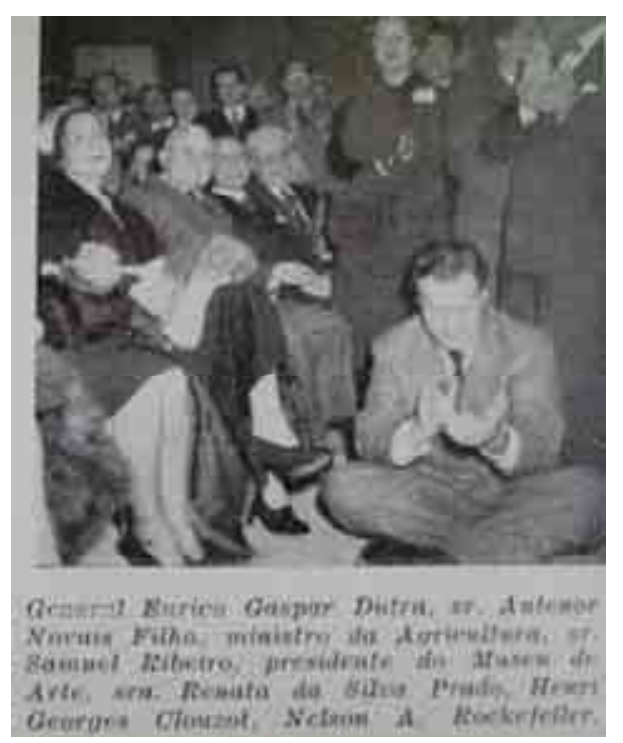

Imagem 27 - Nelson Rockfeller na cerimônia de inauguração das novas instalações do MASP. Revista Habitat, $n^{\circ}$ 1, 1950.

\footnotetext{
${ }^{76}$ Essa reflexão foi inspirada pela leitura de Adorno e Horkheimer, especialmente quando eles se referem ao fato de que no Estado de bem-estar social “ Os trabalhadores, que são na verdade aqueles que provêem a alimentação dos demais, são alimentados, como quer a ilusão ideológica, pelos chefes econômicos, que são na verdade os alimentados.”. Op. cit., p. 141.

${ }^{77}$ Antonio Pedro Tota. O Imperialismo Sedutor. A Americanização do Brasil na Época da Segunda Guerra, São Paulo: Companhia das Letras, 2000, pp. 44-68.

${ }^{78}$ Chateaubriand tinha ligações anteriores com o grupo Rockefeller. Em 1944 conseguiu um empréstimo com David Rockefeller para a compra de empresas farmacêuticas alemãs expropriadas pelo governo Vargas durante a Segunda Guerra. Cf. Morais, op. cit., p. 436.
} 
O paradoxal em tudo isso é que as populações moventes de São Paulo, formadas por todos aqueles que estavam em deslocamento contínuo em busca de uma melhor condição de vida - justamente aqueles que eram vistos como incapazes de compreender o mundo urbano e tecnológico - confluíam muito mais para o grande oceano da modernidade e adaptavam-se melhor aos novos parâmetros culturais por ela exigidos, elaborando intrincadas mecanismos de escape e reutilização, do que as tentativas de fixidez impostas por uma parcela da elite e da intelectualidade paulista, zelosa de seus privilégios, muitas vezes custosamente alcançados, incapaz do desprendimento necessário para lançar-se no turbilhão, impossibilitada de livrar-se do pejo que carregava. ${ }^{79}$

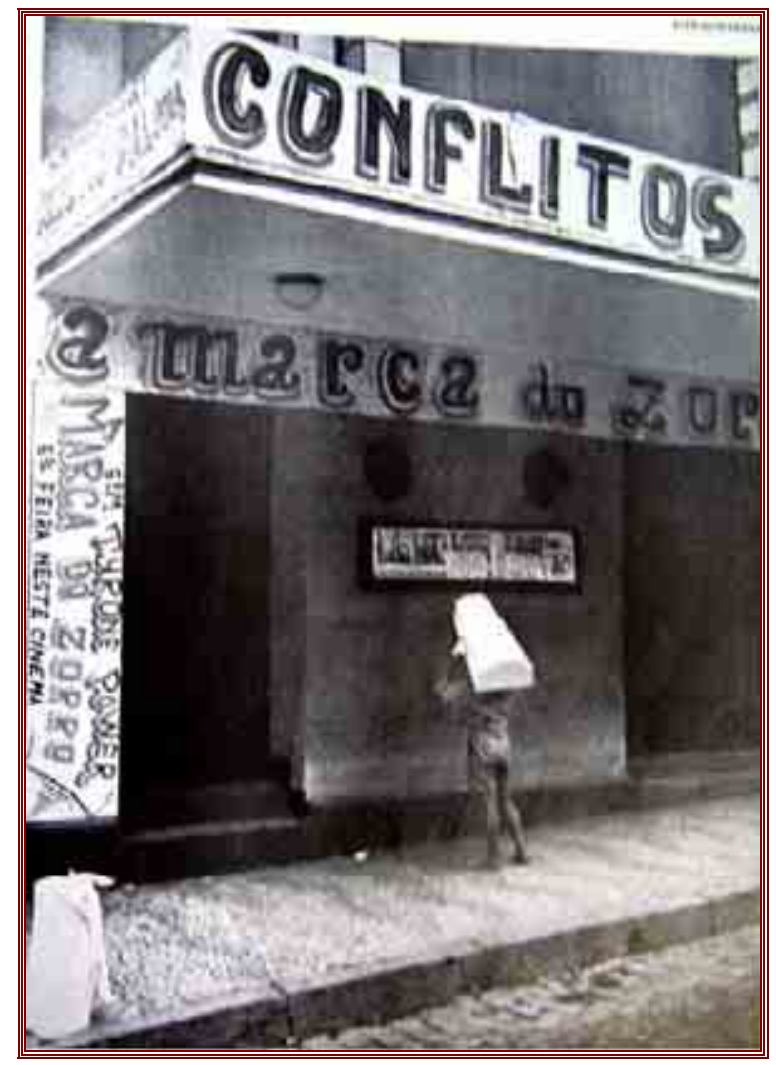

Imagem 28 - "Conflitos".

Sasha Harnish. Revista Habitat, $n^{0}$ 6, 1951.

\footnotetext{
79 Segundo Nicolau Sevcenko, "o mundo da razão, da palavra, da consciência, oriundo da tradição neoclássica, científica e liberal do século XIX, já não trazia resposta em seu vocabulário assentado sobre estabilidades, que dessem conta de representar a nova ordem turbilhonante das coisas." Orfeu Extático na Metrópole, op. cit., p. 31.
} 
A cultura camponesa e sertaneja ágrafa marcada pelo pragmatismo, pelo materialismo extremado - que trazia o plano da fantasia reservado à mitologia, à festa, às crenças - acoplou-se nos grandes centros à cultura do entretenimento, liderada pelo cinema e todo tipo de diversão barata. As imagens ocuparam um espaço que antes estava ampla e secularmente povoado pelas tradições. As migrações possibilitaram a aceleração desse vetor irreversível, colocando à disposição seres desenraizados e suscetíveis a essas solicitações. A técnica rapidamente ocupou o lugar da fantasia, seduzindo por sua espontaneidade. ${ }^{80}$

A publicidade, sagazmente, aproveitou-se dessa condição, lançando estímulos ao desejo, oferecendo mercadorias que estavam quase ao alcance das mãos, mas que eram em seguida arremessadas para outros patamares. Eram como aparições, de uma beleza ímpar e sedutora, que culminavam invariavelmente em frustração, contudo apresentavam como paliativo o reino do similar e a esperança conciliatória da prosperidade futura. ${ }^{81}$

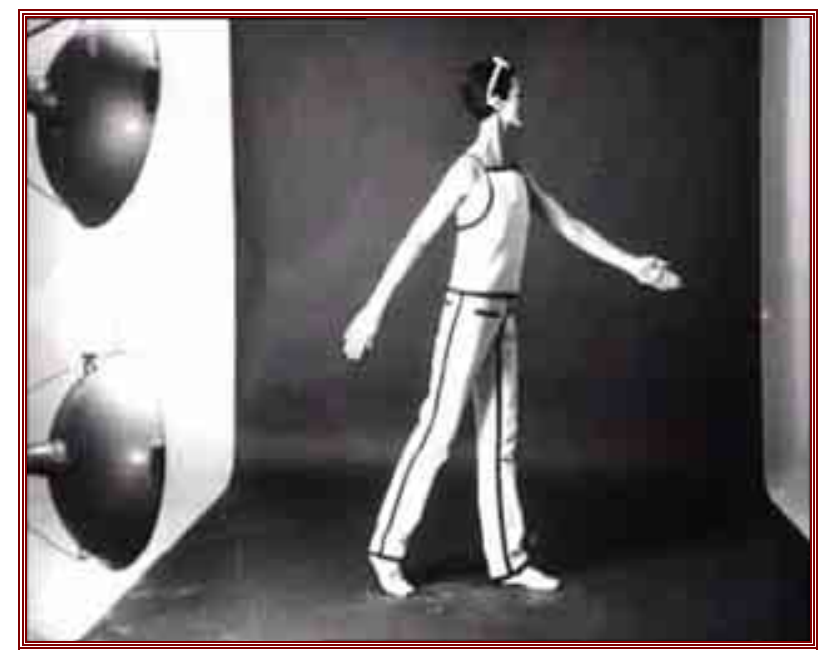

Imagem 29 - Cena do filme de Guy Debord "La Societé du Spetacle”, Paris, 1973.

\footnotetext{
${ }^{80}$ A filha de Carolina Maria de Jesus conta que sua mãe nunca deixava de ir ao cinema: " $A$ despesa de cinema acabava com o pouco de dinheiro para a comida, (...)." Levine e Meihy, op. cit., p. 72. Sobre a fantasia oferecida em espetáculo cf. Nicolau Sevcenko. A Corrida para o Século XXI. No loop da montanha-russa, São Paulo: Companhia das Letras, 2001, p. 81

${ }^{81}$ Sobre a publicidade nas revistas Manchete e O Cruzeiro entre 1954 e 1964 cf. Anna Cristina Camargo Moraes Figueiredo. "Liberdade é uma calça velha, azul e desbotada": publicidade, cultura de consumo e comportamento político no Brasil (1954-1964), São Paulo: HUCITEC, 1998. E também Gisela Taschner. "Raízes da cultura do consumo", in Revista USP, 32, São Paulo: USP/Coordenadoria de Comunicação Social, dez-fev, 1996-7, pp.26-43. Sobre a abundância e a frustração na sociedade de consumo cf. Guy Debord. "O declínio e a queda da economia espetacular mercantil", op. cit. .
} 
Essa São Paulo que se descortinava frente aos olhos dos imigrantes e migrantes que aqui chegavam de certa forma atendia aos anseios desses homens e mulheres que buscavam o desprendimento, fugindo do "cárcere" de formações sociais rigidamente estabelecidas e de meios parcos em recursos de sobrevivência, vivendo "sem pique nem pouso". ${ }^{82}$ Necessitavam da mobilidade para escapar à miséria e à solidificação das imposições socioculturais e era isso que encontrariam em fartura, tornando-a um fator proeminente em São Paulo. ${ }^{83} \mathrm{~A}$ situação de deslocamento contínuo desses adventícios e a pressão especulativa do mercado levaram-nos ao espalhamento. ${ }^{84}$ Embrenharam-se por um verdadeiro labirinto de ruas e bairros distantes, intrincadamente incorporados às pressas à teia da cidade. ${ }^{85}$

O despojamento das camadas populares, possuidoras de um quase nada material, a sua gestualidade impertinente, a sua contumaz itinerância, rica em resquícios de culturas orais camponesas e sertanejas, foram nesse período rearticulados por movimentos de contestação que despontavam na agenda internacional, e também por artistas que conseguiram transpor as barreiras socialmente impostas. ${ }^{86}$ A rebeldia, que transformou o deslocamento em paradigma, estava alicerçada na compreensão do movimento enquanto sinônimo de liberdade, justamente quando a própria possibilidade do movimento sofria uma restrição atroz diante do apego aos bens de consumo cada vez mais disseminados. Deslocar-se se tornava impraticável para os que acumulavam montanhas de quinquilharias e objetos, apenas os destituídos e os inconformados

\footnotetext{
${ }^{82}$ Manuelzão, personagem de Guimarães Rosa, viveu dessa maneira com o objetivo de adiar o sofrimento e evitar a miséria: "Até para sofrer, a gente carece de quietação. (...) Viageiro vai adiando. Só o medo da miséria do uso - um medo constante, acordado e dormindo, anoitecendo, amanhecendo." "Campo Geral" in Manuelzão e Miguilim (Corpo de Baile), 11 a ed., Rio de Janeiro: Nova Fronteira, 2001, pp. 159 e 175-6.

${ }^{83}$ Nicolau Sevcenko em seu texto "Perigrinations, Visions and the City" ressalta a itinerância como dimensão profunda da sociedade brasileira. In Vivian Schelling (org). Through the Kaleidoscope. The Experience of Modernity in Latin America, London: Verso, 2000, pp.75-105.

84 "Tomada a decisão de emigrar, tinha início uma história que se pode dizer de movimento infindo. A mobilidade, já esboçada no século XVIII por aqueles que se dirigiam para as cidades, ou outros países europeus, em busca de empregos, passa a ser normal." Zuleika Alvim. "Imigrantes: a vida privada dos pobres do campo" in Nicolau Sevcenko (org.) História da Vida Privada no Brasil, vol. 3. República: da Belle Époque à Era do Rádio, op. cit., p. 234.

85 "Tudo cresceu, espantosamente na última década(...)." Aroldo de Azevedo. op. cit., vol. II, p. 159.

${ }^{86}$ Internacional Situacionista. Situacionista. Teoria e Prática da Revolução, São Paulo: Conrad, 2002.
} 
ousavam fazê-lo, apontando para o caráter efêmero de tais conquistas materiais. ${ }^{87}$ Nas sábias palavras de Dostoiévski,

Quando se alcança tudo, torna-se penoso tudo perder. (...) quem mais teme é aquele que mais prospera. ${ }^{88}$

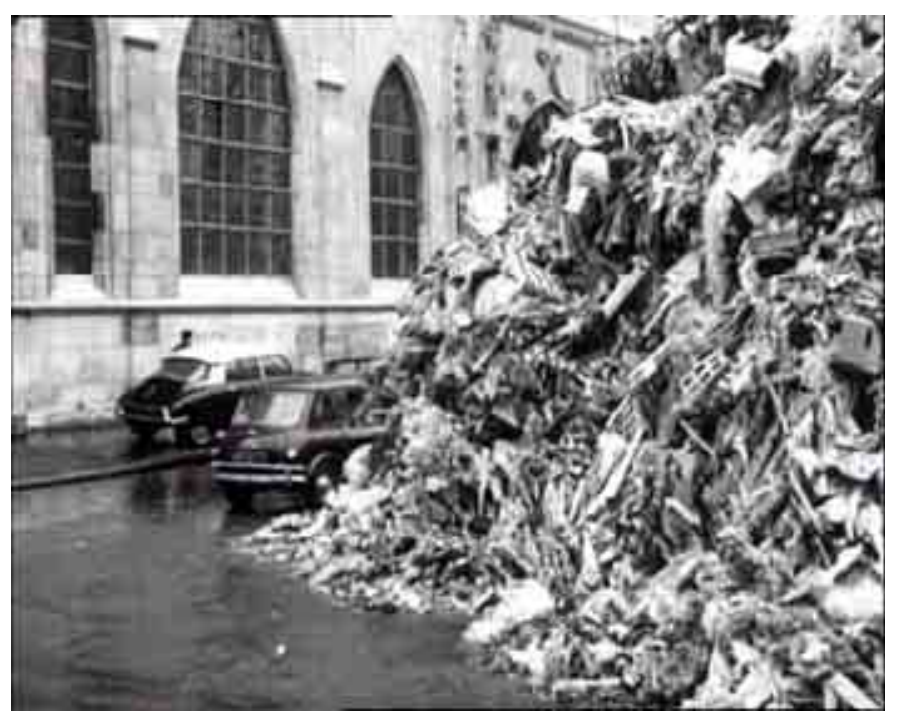

Imagem 30 - Cena do filme de Guy Debord "La Societé du Spetacle”, Paris, 1973.

A mística do movimento enquanto libertação já estava presente nos estratos mais arcaicos da sabedoria popular, expressa por adágios como "Pedra movediça não cria mofo". Da mesma forma o relativismo, tão dificilmente deglutido por aqueles que tem muito ao que se apegar, sempre foi tranqüilamente trabalhado pelos que experimentaram as inconstâncias de sua situação. ${ }^{89}$

Esses grupos que assumiram, conscientemente ou não, os gestos moventes e os mínimos gestos divergentes, tornavam-se inoportunos justamente por denunciarem o movimento da própria vida e a inconstância dos bens

\footnotetext{
${ }^{87}$ Sobre a restrição e perda de sentido do movimento cf. Paul Virilio. A Bomba Informática, São Paulo: Estação Liberdade, 1999, p. 122.

${ }^{88}$ Fiódor Dostoiévski. O Crocodilo e Notas de Inverno sobre Impressões de Verão, tradução de Boris Schnaiderman, São Paulo: Editora 34, 2000, p.136. (1 ${ }^{\mathrm{a}}$ ed. 1864 e 1863)

${ }^{89}$ Jerusa Pires Ferreira observou, por outro lado, como a viagem esteve sempre ligada à mística da purificação. "A viagem, ligada sempre a fins de resgate e a itinerários de purificação está associada por seu aspecto formalizante tópico a regiões visionárias, países de ouro e prata, imagens estas que têm, como se sabe, uma penetração e conservação intensas não só no romanceiro, mas, em geral, no repertório global que compõe o imaginário popular." Cavalaria em Cordel. O Passo das Águas Mortas, 2a ed., São Paulo: HUCITEC, 1993, p. 62.
} 


\begin{abstract}
adquiridos. ${ }^{90}$ Quase como numa ária barroca, lançavam uma profunda sombra sobre a grande festa consumista ${ }^{91}$ e sobre o dourado esplendoroso do mundo que se prometia durante a Segunda Guerra e finalmente parecia se abrir após a catástrofe. $^{92}$
\end{abstract}

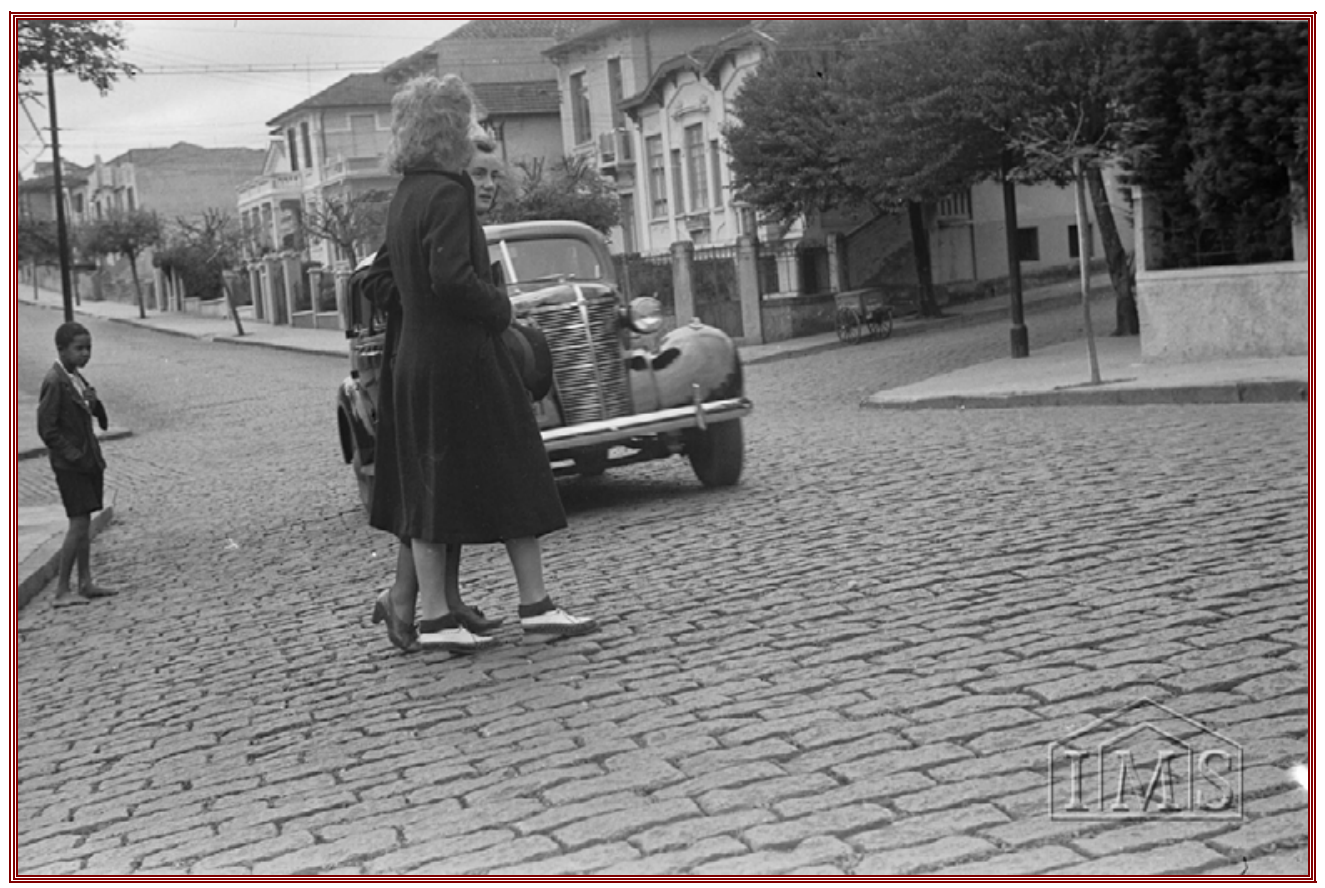

Imagem 31 - Menino no canto da rua, São Paulo, 1940. Hildegard Rosenthal / Acervo Instituto Moreira Salles. Código: 005HRP002.014

\footnotetext{
${ }^{90}$ Segundo Eric Hobsbawm, após 1945, os trabalhadores estavam seduzidos pela possibilidade da aquisição do conforto, anteriormente reservado às camadas mais ricas. Era dos Extremos. O Breve Século XX, 19141991, 2a ed., São Paulo: Companhia das Letras, 1997.

${ }^{91}$ Essa expressão foi utilizada por Nicolau Sevcenko no artigo "O grande motim" para referir-se aos anos 50. "Às margens da grande festa consumista iam ficando os desprezados de sempre: os brancos sem acesso à educação, os negros, os índios, os latinos e as legiões de imigrantes flagelados pelo furacão da guerra. Foi dessa horda de renegados que partiu a reação." Folha de São Paulo, 20/09/98, Caderno Mais, p. 5.

92 Durante a Guerra, seguindo orientações de Nelson Rockefeller, as empresas norte-americanas anunciaram os produtos que estariam disponíveis após a vitória. No Brasil essas mensagens chegavam principalmente através da revista Seleções do Reader's Digest, publicada no país desde 1942. Tota, op. cit., pp. 57-59. Para Roberto Casati, "A sombra fala. Ela nos conta como são feitos os objetos desenhando seu claro-escuro: e nos mostra as posições dos objetos uns em relação aos outros, em relação às fontes de luz e em relação ao espaço em que estão imersos." Roberto Casati. A Descoberta da Sombra. De Platão a Galileu, a História de um Enigma que Fascina a Humanidade, tradução Eduardo Brandão, São Paulo: Companhia das Letras, 2001, p. 91. E a luz, segundo Philippe Dubois. "é, portanto, o que é necessário ao surgimento da imagem, mas é também o que pode fazê-la desaparecer, apagá-la, eliminá-la por inteiro: é preciso se proteger dela tanto quanto procurá-la." Philippe Dubois. O Ato Fotográfico e Outros Ensaios, tradução de Marina Appenzeller, Campinas: Papirus, 1994, p. 222
} 
Os anos encantados chegavam em ebulição para ocupar todo o mundaréu.

"Aí Ogum já vem na estrada Olha o brilho da sua espada

Quem corre nas ondas do mar?

Iemanjá que já vai chegar.

Oxossi deixa a floresta

Vem vadiar em nossa festa

Que perfume, quanta flor e quanta fita

É Oxum, a deusa mais bonita

Com suas chagas a doer

O Babaluaê vem para nos benzer.

Pedra rolou na cachoeira

É Xangô descendo a pedreira

Olha o relâmpago correu no céu

É Iansã, dona do mundaréu."

(M.A.Jangada e Toniquinho, $O$ Canto dosEncantados) ${ }^{93}$

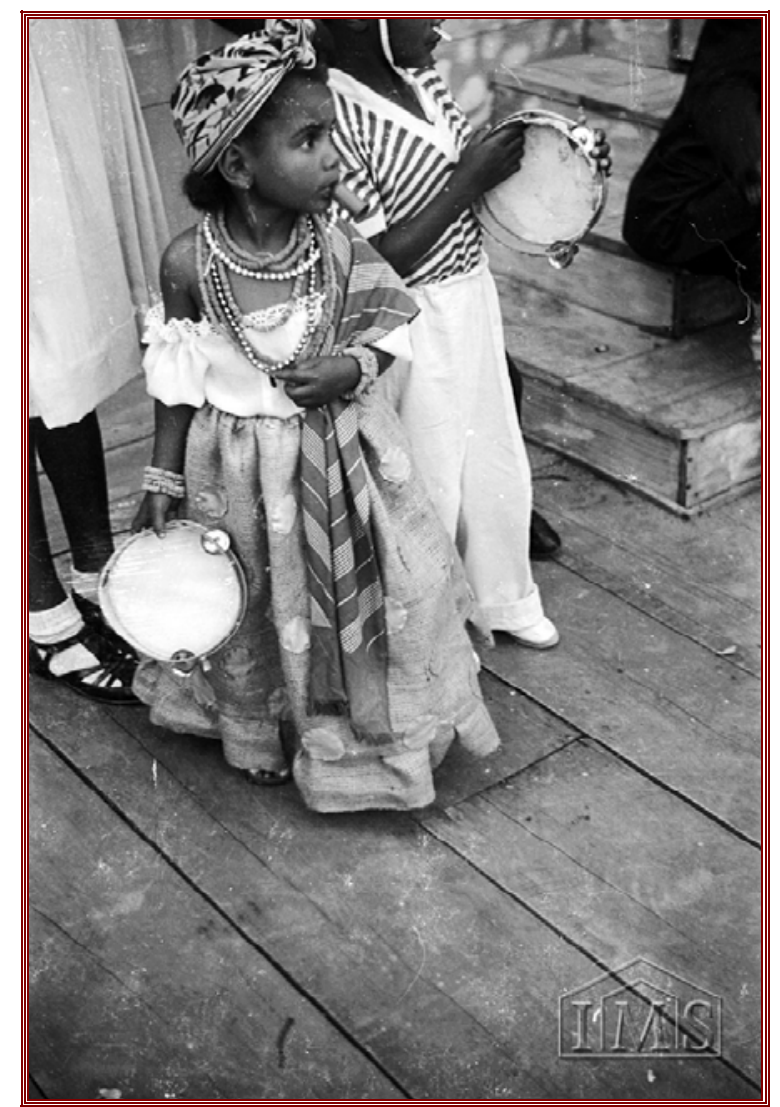

Imagem 32 - "Menina fantasiada", São Paulo, SP, 1940.

Hildegard Rosenthal / Acervo Instituto Moreira Salles. Código: 005HRP087.024

${ }^{93}$ Disco Balbina de Iansã, trilha sonora do espetáculo teatral de Plínio Marcos, 1971. 


\section{Desejos, Deslocamentos, Situações. \\ Percursos teórico-metodológicos}

E bastante outras coisas eles decifravam assim, vendo espiado o que de graça no geral não se vê.

(Guimarães Rosa. Grande Sertão: Veredas)

O interesse pelo tema deste trabalho surgiu a partir do meu mestrado, concluído em 2000, no qual estudei a imigração galega em São Paulo no pós Segunda Guerra Mundial. ${ }^{1}$ A idéia naquele momento era fugir do discurso hegemônico nacionalista sobre a imigração e procurar nos desvãos dos documentos indícios que possibilitassem a compreensão desse movimento a partir de um grupo de mais ou menos 26 mil pessoas que entraram no Brasil através do Porto de Santos entre os anos de 1946 a 1964, vindos da Espanha. Grupo esse não articulado politicamente, de origem camponesa, considerado semiletrado, sem preparo técnico e que na cidade de São Paulo se dispersou por todo espaço urbano, assumindo as mais diferentes ocupações, em geral no setor de serviços. O que pretendi naquele trabalho foi ressaltar o aspecto cultural e irreversível desse deslocamento, além de ter seguido uma abordagem política que buscava desprender-se do conceito de identidade.

A partir dessa pesquisa pude aprofundar minha compreensão sobre a história de São Paulo nos anos 40, 50 e 60 e, principalmente, com a história dos grupos moventes que circulavam ininterruptamente pela cidade, sem paradeiro fixo, trocando o tempo todo de moradia e de profissão. Essas pessoas, vindas de rincões distantes do planeta, do sertão, das pequenas cidades do interior, egressos do campo, traziam em si, na mente e no corpo, fragmentos culturais os mais diversos aos quais mesclaram o que encontraram e selecionaram pelo caminho.

Como para os galegos, comecei então a compreender que a terra também não era firme para esses grupos, o que tornava necessária a busca por um pensamento mais amplo que levasse em consideração as interações,

\footnotetext{
${ }^{1}$ Elena Pájaro Peres. A Inexistência da Terra Firme. A Imigração Galega em São Paulo, 1946-1964, São Paulo: EDUSP/FAPESP/IMESP, 2003.
} 
os caminhos cruzados dessas populações deambulantes. Para alcançar esse pensamento seria preciso mais uma vez perseguir, tentar ler os sinais, os códigos deixados por esses seres, muitas vezes invisíveis na historiografia do período, mas acima de tudo, como percebi no decorrer do trabalho, invisíveis por astúcia e por necessidade, envoltos por uma espécie de camuflagem no decorrer de sua errância.

A invisibilidade como forma de proteção e de artimanha sempre foi almejada. Desde períodos remotos da história só os iniciados tinham acesso às práticas mágicas que poderiam levar a tal situação, por sinal proveitosa para aqueles que necessitavam ocultar-se ou fugir para continuar vivendo. ${ }^{2} \mathrm{~A}$ invisibilidade obtida através do movimento rápido e furtivo, do deslocamento incessante é essencial para a prática da caça não autorizada ou braconnage de que nos fala Michel de Certeau, ou seja, a caça furtiva levada a cabo nos espaços interditos, clandestinamente, nos campos do senhor. ${ }^{3}$ Essa caça não visa apenas objetos materiais e visíveis, mas também e principalmente elementos culturais, muitas vezes invisíveis ao olhar direto, que são capturados e transformados pelo desvio no uso, pelo détournement, como o concebeu Guy Debord e o próprio Certeau. ${ }^{4}$

Para um tal objeto de pesquisa, movediço e inconstante, assustadiço e fugidio, percebi que o cuidado maior teria que estar em não jogar luz excessiva com a intenção de enxergar o que não é visível - mesmo porque, ao que é invisível não adiantaria jogar luz, pois continuaria sempre invisível. A única coisa que se conseguiria, com uma luz excessiva, ou seja, um desnudamento racionalizador e sistemático, seria a destruição de qualquer tipo de sombra, a extinção da obscuridade onde esses seres se manifestam, e aí sim, não chegaria nem perto daquilo que se quer compreender.

As sombras, projetadas pelos destituídos e inconformados, são aqui entendidas como sua forma de inserção na cidade e estavam compostas pelos

\footnotetext{
${ }^{2}$ Em manuscritos do século XV, encontram-se prescrições para a prática da magia da invisibilidade, sempre repleta de riscos. Em um deles, escrito em latim, após um complexo ritual o mago pede ao espírito evocados um capuz de invisibilidade, semelhante ao capuz que aparece na história de Peter Schlemihl. Cf. Richard Kieckhefer. La Magia nel Medioevo, tradução para o italiano de Frederico Corradi, 2a ed., Roma: Laterza, 2003, p.11.

${ }^{3}$ Michel de Certeau, A Invenção do Cotidiano, op. cit..

${ }^{4}$ Sobre o detournement: "Os situs usavam o termo no sentido concebido por Lautremont: um método que consiste em tomar as coisas dos inimigos para montar uma outra coisa, que ajude a combater o inimigo." Cf. Marietta Baderna na apresentação do livro Situacionista. Teoria e Prática da Revolução, op. cit., p. 16.
} 
resíduos - remanescentes das culturas camponesa e sertaneja - trazidos pelos imigrantes e migrantes que chegaram a São Paulo em diferentes momentos. Esses resíduos foram retrabalhados por eles a partir das sobras urbanas - de tudo aquilo que fôra despejado como inútil por uma sociedade paulistana orgulhosa de seu futuro promissor - e em conluio com a cultura de consumo e entretenimento que se expandia. Como esse espólio mesclou-se aos desejos, expectativas e frustrações criando formas de experiência que em muito ultrapassavam as formas de sobrevivência é o que se acreditou ser possível compreender. ${ }^{5}$

A existência dessa sombra é o que possibilita ver o contexto, distinguir os relevos, perceber os contornos que separam esse instante da história daquele que veio antes e daquele que vem logo a seguir, em que a sombra foi se transformando em penumbra e a nitidez da imagem se viu aos poucos prejudicada pela ocultação das nuances, pela tentativa intensa de estandardização e pela adesão incondicional à luz.

Então, rastreando por fontes diversas - legislação, revistas, jornais, literatura, cinema, música, teatro, iconografia, correspondências, documentos do Movimento Universitário do Desfavelamento - procurei por indícios de toda essa camada que permaneceu na invisibilidade, mas que, por outro lado, traz em si uma exuberância incontida.

Seguir as trilhas dos destituídos e dos inconformados não é empreitada fácil. Poucos foram os registros escritos deixados por quem estava em movimento e por vezes até em fuga. Sabe-se que o nomadismo e a escrita nunca se confraternizaram. Entretanto, existem alguns rastros que foram deixados e que podem ser recuperados através de várias fontes e do olhar indireto em relação ao foco da pesquisa. ${ }^{6}$

\footnotetext{
${ }^{5}$ Segundo Ecléa Bosi, a etmologia de experiência, ensinada pelo professor Flavio Di Giorgi, refere-se ao que salta fora (ex) do perímetro de um círculo já percorrido. Cf. Ecléa Bosi. O Tempo Vivo da Memória. Ensaios de Psicologia Social, São Paulo: Ateliê, 2003, p. 42. Pensando assim, formas de experiência supõem tudo o que se afasta do amplamente conhecido e repetido. Para Walter Benjamin, experiência relaciona-se ao sobressalto, ao choque e distancia-se do conceito de vivência que implica reflexão. Cf. Walter Benjamin. "Sobre Alguns Temas em Baudelaire" in Charles Baudelaire. Um Lírico no Auge do Capitalismo, Obras Escolhidas, vol. III, 2ª ed., São Paulo: Brasiliense, 1991, p. 111.

6 "O sensível não é feito somente de coisas. É feito de tudo que nelas se desenha, mesmo no oco dos intervalos, tudo que nelas deixa vestígio, tudo que nelas figura, mesmo a título de distância e como uma certa ausência: (...)." Maurice Merleau-Ponty. "O filósofo e sua sombra", tradução de Marilena de Souza Chauí, in Textos Selecionados, São Paulo: Nova Cultural, 1989, p.200. (Os Pensadores).
} 
Trabalhar com temas relativos à cultura de populações moventes e com o que Nicolau Sevcenko chamou de

âmbitos difusos da informalidade e das existências semiclandestinas dos grupos subalternos que sobrevivem na liminaridade da rede urbana e da vida pública, ${ }^{7}$

exige a retração do projeto acadêmico como forma de se adquirir uma maior sensibilidade, evitando-se, por um lado, o uso de um instrumental analítico que leve a uma abordagem brusca e frontal do tema em estudo e, por outro, o uso de expressões lineares que tenderiam a distender o volteado característico de tais manifestações, apagando de vez o "rústico alfabeto" que foi inscrito de forma delicada numa superfície instável. ${ }^{8}$

A sinuosidade das trilhas percorridas pelos protagonistas dessas histórias permite apenas o rastreamento, uma aproximação pelas fímbrias ou pelas sombras, num olhar espiado, indireto, desatento, que nos leva a sentir, mais do que ver, a exuberância do que permanece invisível. ${ }^{9}$

como a sombra e o reflexo, também eles seriam destruídos se submetidos à observação analítica ou ao pensamento isolante. ${ }^{10}$

Nesse caminho tentei perceber alguns mediadores. A idéia não era localizar pessoas consideradas "de fora" que tentaram penetrar nesse universo, nem tampouco perscrutar o âmago dessa dimensão a partir de personagens considerados "de dentro", mas sim, o que me pareceu mais interessante para perceber as tensões, era encontrar mediadores que atravessaram, a todo instante, de lá para cá, de cá para lá, num entrecruzar incessante de caminhos,

\footnotetext{
${ }^{7}$ Observação feita pelo orientador Professor Dr. Nicolau Sevcenko ao primeiro relatório científico enviado à FAPESP em maio de 2005.

${ }^{8}$ Sérgio Buarque de Holanda, no texto "Veredas de Pés Posto", aponta a existência de uma cultura do rastro entre os povos indígenas no Brasil, baseada no espírito de observação permanentemente desperto que permite a leitura de um rústico alfabeto, acessível apenas àqueles acostumados a uma existência andeja. Cf. Caminhos e Fronteiras, $3^{\text {a }}$ ed., São Paulo: Companhia das Letras, 2005. (1 ${ }^{\text {a }}$ ed. 1956, José Olympio).

9 "O que precisaríamos para situar o universo da sombra empirista-rococó, e o que aparentemente não temos, é uma idéia clara da percepção especificamente desatenta como complemento produtivo da percepção atenta - atenção, dessa vez, no sentido de uma investigação atenta e dirigida, focalizada e construtiva, numa certa relação recíproca com a consciência." Michael Baxandal. Sombras e Luzes, tradução de Antônio de Pádua Danesi, São Paulo: EDUSP, 1997., p.173.

${ }^{10}$ Merleau-Ponty compara nesse trecho a sombra e o reflexo ao pensamento e obras de um filósofo. $O p$. cit. , pp. 189-90.
} 
sumindo e ressurgindo o tempo todo, transformando-se em canais de comunicação possíveis entre as diferentes esferas.

São seres que, num primeiro momento, chamei de fronteiriços, ou seres de fronteira, imaginando uma linha demarcatória entre o universo da oralidade e o da escrita, entre o mundo do gestual espontâneo e da pose pensada, entre o universo do ritmo e do passo ensaiado. Se estivessem na fronteira, estariam entre pólos, numa zona limítrofe e transitória. Todavia, como eu já havia recusado a denominação de margem no meu trabalho anterior, optando pela noção de inexistência dessas margens e pela idéia de que o fluxo era o mais importante para a compreensão da imigração, seria também inapropriado pensar em fronteira, palavra de origem militar, cuja acepção remete a noções de disciplina e limitação territorial, e que foi posteriormente cooptada para uso estatal, sempre carregando em sua significação a condição básica de paralisação, estancamento, limite, circunscrição, imobilidade e divisão.

Portanto, esse termo não me pareceu acertado para tratar de seres caracterizados espacial e culturalmente pela mobilidade e flexibilidade em seus constantes encontros com o novo, o inusitado e o contingente. Melhor seria pensar numa "rede de linhas e de vias de comunicação entrecruzadas" seguindo a inspiração do viajante Bruce Chatwin, em Songlines, imagem de maior complexidade que envolve uma tensão contínua não entre pólos opostos, mas entre diversas dimensões, não estabelecendo ponto fixo nem a certeza de um único traço que demarcasse a separação, mas sim a perene ambivalência. ${ }^{11} \mathrm{O}$ que me interessou foi a mistura espontânea de elementos culturais, não sendo possível demarcar rigidamente onde se dá o encontro, muito menos prevê-lo. Encontro esse sempre provisório, apesar de irreversível.

Esses personagens então, que me ajudariam a perceber a sombra, encontravam-se nesse "itinerário de trocas", num espaço bastante conflituoso e, por vezes, divergente. ${ }^{12}$

Assim pude pelo caminho encontrar alguns deles:

\footnotetext{
${ }^{11}$ Bruce Chatwin. Les Chants des Pistes, traduit par Jacques Chabert, Paris: Grasset \& Fasquelle, 1988, p.85.

${ }^{12}$ Idem, ibidem.
} 
- A escritora, lavradora, catadora de papel, compositora, sambista, poetisa, dramaturga, cantora, atriz circense, raizera - Carolina Maria de Jesus. Conhecida por seu livro Quarto de Despejo, publicado em 1960, que teve seus 10 mil exemplares vendidos em uma semana e que foi traduzido para 13 idiomas. Nesse diário, escrito em cadernos catados do lixo, contava o dia-a-dia de sua vida na favela do Canindé, onde morou de 1947 a 1960 e de onde saiu apedrejada, após a publicação do livro. Carolina cursou apenas até o segundo ano primário e começou a escrever quando chegou a São Paulo no final dos anos 40. Segundo ela mesma, escrevia para acalmar sua mente. Falava pouco e vivia fazendo inscrições, incompreensíveis para muitos dos seus vizinhos, o que fez com que fosse vista pelos moradores do Canindé como uma espécie de feiticeira.

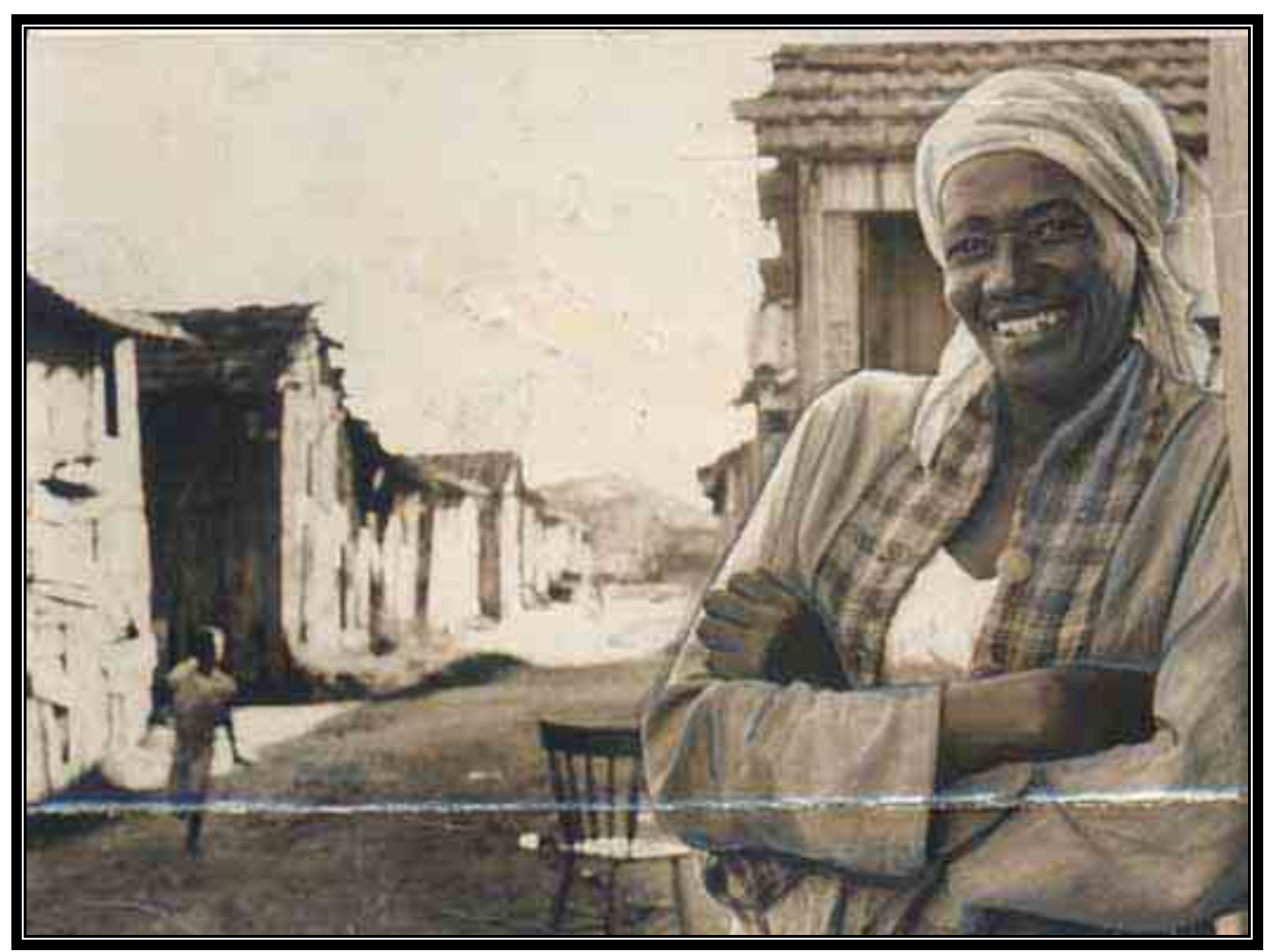

Imagem 1 - Carolina Maria de Jesus na Favela do Canindé, 1960. Jornal Última Hora, 26/08/60 / Arquivo do Estado de São Paulo. Arquivos Especiais-Iconográfico. Código: ICO-UH-0369-Carolina Maria de Jesus.

-O cineasta, fotógrafo, caminhoneiro, operário, vendedor de sorvete, cafetão, militar, funcionário público Ozualdo Candeias conhecido a partir de seu 
filme "A Margem" de 1967, considerado por muitos, mas não por ele mesmo, como o precursor do cinema marginal. Candeias iniciou seu trabalho no cinema com documentários na década de 50 .

-O escritor, ajudante de armazém, office boy, jornalista, publicitário, jogador de sinuca, músico João Antonio, ganhador de inúmeros prêmios com seu livro de estréia Malagueta, Perus e Bacanaço, de 1963. Menino do Morro da Geada em Osasco.

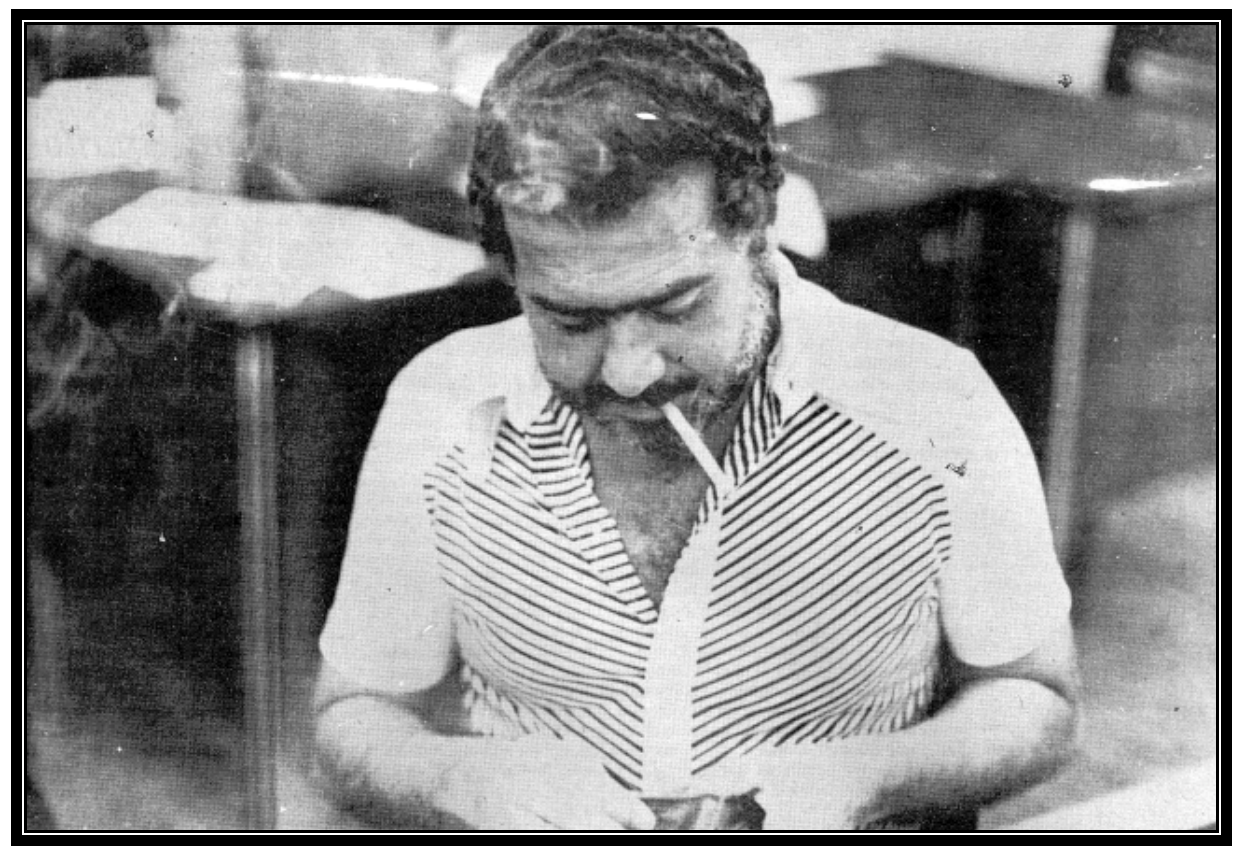

Imagem 2 - João Antonio. Acervo Arquivo João Antônio - UNESP - Assis

-O dramaturgo, ator, cronista, jogador de futebol, palhaço de circo, funileiro, camelô, soldado, bancário, biscateiro do Porto de Santos, colecionador de figurinhas, esotérico, leitor de tarô, poeta, compositor Plínio Marcos. Escreveu a peça teatral Barrela em 1958, que teve apenas uma apresentação e foi imediatamente censurada, em tempos do presidente JK. Seguiu escrevendo e sendo sucessivamente censurado acusado de pornografia e subversão.

Esses seres inconformados, viradores como dizia o próprio João Antonio, continuamente circulavam por ambientes culturais diversos aproveitando tudo o que encontravam, evidenciando a mescla, o conflito, a 
tensão em suas obras e em suas vidas, tendo muitas coisas em comum, principalmente o contexto em que surgiram:

- Momento de euforia estampada pela imprensa, época da exaltação da cidade descomunal, São Paulo, com seus arranha-céus, ares de american city, teatros, museus de arte, bienais e a festa suprema do IV Centenário, período da chamada "redemocratização" que teria atingido seu auge com o presidente bossa-nova JK. ${ }^{13}$

- Época também de racionamentos, demolições de casarões populares, surgimentos das primeiras favelas paulistas, inflação implacável, greves, quebra-quebras, alta especulação imobiliária levando ao espalhamento e à aglomeração populacional, redirecionamento político do país, voltando-se para os Estados Unidos, inchaço populacional dos grandes centros, aprimoramento da publicidade e da cultura de consumo, incremento da sucata, que as populações moventes souberam reaproveitar como ninguém.

Nesse contexto, não é possível aplicar a esses personagens uma trajetória linear. Foi o improviso, a instabilidade, a dispersão o que mais marcou suas vidas como a de todos que tiveram de enfrentar o deslocamento. A obra de cada um deles é antes de tudo autobiográfica e ao mesmo tempo demonstra sistemas complexos de interação. Obra que deve ser inserida numa dimensão coletiva, uma vez que foi a partir dessa dimensão que ela se fez.

Para tentar demonstrar essa inserção dividi o trabalho em três capítulos, cada qual abordando o assunto mais intensamente por um viés. Na introdução, A Sombra dos Invisíveis, pretendi trazer a ambiência da problemática escolhida, através da configuração do que chamei de Tessitura Visual.

O objetivo do primeiro capítulo, São Paulo, a Cidade Movente, é entrever, a partir das inscrições de um "rústico alfabeto", os desejos de

\footnotetext{
${ }^{13}$ Muitos trabalhos que se referem aos anos 50 em São Paulo dão destaque a festa do IV Centenário e seu clima de euforia, dentre eles pode-se citar o trabalho de Antonio A. Arantes. Paisagens Paulistanas Transformações do Espaço Público, Campinas: Editora da UNICAMP; São Paulo: Imprensa Oficial, 2000; Sílvio Luis Lofego, IV Centenário da Cidade de São Paulo: uma cidade entre o passado e o futuro, São Paulo: Annablume, 2004.
} 
abundância, igualdade e libertação presentes nos estratos culturais mais arcaicos das populações moventes de São Paulo e como esses desejos se ligaram ao novo contexto cultural encontrado na cidade. Tento compreender algumas das alternativas inventadas por essas populações diante do confronto com o mundo urbano e tecnológico, levando em consideração que esse confronto expôs mais nitidamente a fratura entre tempo histórico e tempo encantado. Para isso, sigo o percurso afetivo daqueles que se encontravam nas vias de comunicação entrecruzada entre a cultura formal, o espetáculo e o gesto espontâneo, ou seja, os mediadores culturais que se movimentaram pela cidade e tentaram inverter a lógica do planejamento através da representação desses desvios.

No segundo capítulo, trato dos deslocamentos espaciais e culturais empreitados por aqueles que precisavam "se virar" na grande metrópole, contornando os obstáculos através de desvios. Ao mesmo tempo busco revelar as tentativas de aprisionamento dos gestos espontâneos dessas populações e as propostas de sua substituição pelo comportamento ensaiado, bem como as iniciativas que objetivavam a ocultação dos que eram considerados como um problema social.

No terceiro e último capítulo abordo a questão do entrecruzamento entre escrita e oralidade, temática que adquiriu posição central em meados do século $X X$, em decorrência do impacto dos novos e cada vez mais amplificados meios de informação. Concluindo busco compreender a obra dos mediadores culturais estudados como a busca da exuberância e o inconformismo pela estandarditização.

A escolha dos teóricos que me auxiliaram no transcorrer da pesquisa deveu-se às possibilidades de desprendimento oferecidas por suas obras, importantes fontes de inspiração, revolvendo idéias pré-estabelecidas e apontando sempre para a pertinência do desvio. Um tema oblíquo exigia o amparo de um pensamento não linear, nesse sentido optei por teorias abertas que permitissem o trabalho com uma base arenosa e de fácil dispersão.

A maior parte dos autores incluídos na discussão da tese compuseram seu pensamento a partir do pós Segunda Guerra, o que os torna, paradoxalmente, inspiração teórica e fonte para a compreensão do período escolhido, não se podendo erguer barreiras entre uma dimensão e outra. 
Com essa investigação propus o estudo da cultura por uma vertente não canônica - deixando de lado as instituições e aqueles que por elas foram beneficiados - convergindo para o conteúdo humano, imaginativo e desejante presente na cidade de São Paulo na segunda metade do século $X X$. Parti assim de uma concepção de cultura como criação móvel e movente, que envolve o uso experimental e tático de elementos dispensados por diferentes segmentos da sociedade e das sobras de tradições as mais diversas por parte daqueles que não tinham paradeiro, mas que buscavam um canto. O que traz em si o desvio (détournement) situacionista de Guy Debord, a caça nãoautorizada (braconnage) de Michel de Certeau e a viração de João Antonio, ou seja, a apropriação não permitida, nas fímbrias da invisibilidade, daquilo que é lançado pela sociedade e o seu uso em sentidos diferentes daqueles que foram determinados, não apenas com a intenção de sobrevivência, mas também, e foi o que aqui mais me interessou, com a possibilidade do "desperdício" da criação.

A Invenção do Cotidiano de Michel de Certeau foi de extrema importância para a compreensão das táticas empregadas pelas populações moventes, os papéis informais que assumiram no dia-a-dia da cidade. ${ }^{14}$ Suas idéias mostram-se pertinentes quando cruzadas com fontes literárias que indicam essas táticas, como é o caso da obra dos mediadores com os quais trabalhei.

Certeau, na conclusão de $A$ Cultura no Plural, livro anterior à Invenção do Cotidiano, reconhece que a cultura oscila entre duas formas:

\begin{abstract}
De um lado, ela é aquilo que "permanece"; do outro, aquilo que se inventa. Há, por um lado, as lentidões, as latências, os atrasos que se acumulam na espessura das mentalidades, certezas e ritualizações sociais, via opaca, inflexível, dissimulada nos gestos cotidianos, ao mesmo tempo os mais atuais e milenares. Por outro, as irrupções, os desvios, todas essas margens de uma inventividade de onde as gerações futuras extrairão sucessivamente sua "cultura erudita". A cultura é uma noite escura em que dormem as revoluções de há pouco, invisiveis, encerradas nas práticas -, mas pirilampos, e por vezes grandes pássaros noturnos, atravessam-na; aparecimentos e criações que delineiam a chance de um outro dia. ${ }^{15}$
\end{abstract}

\footnotetext{
${ }^{14}$ Michel de Certeau. A Invenção do Cotidiano (Artes de Fazer), 4 a ed., Petrópolis: Vozes, 1999.

15 Michel de Certeau. A Cultura no Plural, tradução de Enid Abreu Dobránszky, Campinas: Papirus, 1995, p. 239.
} 
Esses momentos únicos em que pássaros noturnos atravessam o grande céu da cultura, parece ser o momento poético, aquele que, devido a circunstâncias favoráveis despontou da mesmice cotidiana. O que Certeau nos leva a crer é que esse momento não é tão raro, nem tão separado, como nos faz pensar a crítica burguesa. O problema é que, na maioria das vezes, o pássaro passa e não estamos olhando para o céu. Entretanto, se rastrearmos, poderemos ver sua sombra projetada no solo e é justamente no solo que o movimento acontece.

Segundo Nicolau Sevcenko, há uma ambigüidade elementar em todo sistema cultural:

enquanto, num primeiro gesto, ele é a expressão das contradições do homem, funde liberdade e angústia em doses insuportáveis (como nas Flores do Mal, de Baudelaire), já num segundo momento, organizado como um saber sobre o mundo, implica uma clausura repetitiva e estéril, embora material e psicologicamente muito confortável. ${ }^{16}$

Esse segundo momento é aquele no qual as referências se estabilizam, quando o labirinto cultural, composto por uma rede intrincada de passagens e trilhas que se interseccionam em alguns pontos para se distanciarem mais além, se torna familiar. Penso que em determinados casos o grau de estabilização e estreitamento é tal que a intolerância mais completa a qualquer alteração reveste todo o sistema e não se consegue mais reconhecer a instabilidade das fontes. Por exemplo, quando um determinado grupo pensa possuir uma cultura pura ou uma identidade, não reconhecendo sua origem multifacetada e instável.

Em algumas situações e momentos históricos essa ambigüidade entre o perder-se e o achar-se, entre a expressão da liberdade e o enclausuramento, se torna mais transparente. São momentos longe do equilíbrio que inevitavelmente culminam em uma bifurcação, quando as flutuações se amplificam e, por um instante, várias soluções parecem como possíveis, até que um caminho é tomado. ${ }^{17}$

Michel Maffesoli em O Conhecimento Comum ajuda a focalizar o aspecto residual e fragmentário do cotidiano dos destituídos e inconformados,

\footnotetext{
${ }^{16}$ Nicolau Sevcenko. “A Ordem e o 'Sinistro'. Ordenação e Vertigem. Catálogo do evento realizado no Centro Cultural Banco do Brasil - São Paulo, setembro de 2003.

${ }^{17}$ Ilya Prigogine. O Nascimento do Tempo, tradução de João Gama, Lisboa: Edições 70, 1991.
} 
marcado mais pela alteridade do que pela identidade, fugindo sempre das abstrações generalizantes que possam ser construídas. ${ }^{18}$

Tomando a literatura como um dos focos privilegiados para o estudo da história, são sugestivas as observações de Nicolau Sevcenko. Segundo ele, a literatura não pode ser vista como mera fonte de informações contextuais,

(...) não é um meio para se chegar a uma realidade histórica que estaria nalgum lugar para além dela: ela é a própria história expressa como linguagem verbal, um fluxo de tensões que compõem em arranjos sintáticos, estilísticos e semiológicos, conflitos homólogos àqueles através dos quais se põem em confrontos grupos, classes e indivíduos no seio da sociedade. ${ }^{19}$

A literatura é uma das trilhas percorridas para que se tentasse a aproximação com os desejos dos inconformados, porque, ainda segundo Sevcenko,

Se a literatura moderna é uma fronteira extrema do discurso e o proscênio dos desajustados, mais do que o testemunho da sociedade, ela deve trazer em si a revelação dos seus focos mais candentes de tensão e a mágoa dos aflitos. Deve traduzir no seu âmago mais um anseio de mudança do que os mecanismos de permanência. Sendo um produto do desejo, seu compromisso é maior com a fantasia do que com a realidade. Preocupa-se com aquilo que poderia ou deveria ser a ordem das coisas, mais do que com o seu estado real. ${ }^{20}$

Ela também possibilita a fuga da idealização racionalista da realidade fortemente presente no discurso científico, trazendo um pouco até nós a poesia da vida, mesmo quando redigida em prosa.

Em extratos marcados muito mais pela oralidade do que pela escrita, como é o caso das populações moventes, essa última tende a assumir um aspecto ritualístico, reservado aos poucos iniciados. ${ }^{21}$ Por outro lado, trata-se

\footnotetext{
${ }^{18}$ Michel Maffesoli. O Conhecimento Comum. Compêndio de Sociologia Compreensiva, São Paulo: Brasiliense, 1988.

${ }^{19}$ Nicolau Sevcenko. "Cogumelos depois da chuva”, in Memória, Ano V, nº 19, São Paulo: Departamento de Patrimônio Histórico da Eletropaulo, julho a dez. de 1993, p. 64.

20 Nicolau Sevcenko. Literatura como Missão. Tensões Sociais e Criação Cultural na Primeira República, 2a ed., São Paulo: Companhia das Letras, 2003, p. 29.

${ }^{21}$ Segundo Kieckhefer, "In a culture where writing is uncommon, it may well appear magical. Even ordinary script may seem to bear extraordinary power, and it is not surprising when people in search of magical weapons or magical protection seize upon the written word." Cf. Magic in the Middle Ages, Cambridge: Cambridge University Press, 2000, p.47.
} 
também de um instrumento de poder que confere autoridade à quem dele faz uso, assustando por vezes aos que não detêm o código escrito.

Uma questão importante a ser pensada, quando se aborda o tema da palavra escrita, é o fato que ela, por ser registrada, dificulta a astúcia, o escape e o desvio, fixando idéias, valores, desejos, embaraçando tudo aquilo que na oralidade, por sua vez, permite a maleabilidade e a confusão e que garante a permanência da dúvida pelo esquecimento e pelo desdito. ${ }^{22}$

Entretanto, mesmo com esse encarceramento da fixidez, o código escrito pode se tornar um instrumento de inversão. Tarefa de difícil envergadura e que precisa ser constantemente refeita, dada a apropriação eficaz da escrita pelo discurso dominante. Essa inversão da escrita pode ser encontrada naqueles que se afastaram do discurso hegemônico, que em São Paulo dos anos 40, 50 e 60 é o do desenvolvimento e da comemoração. ${ }^{23}$

No caso do cinema de Candeias, e da obra de Plínio, Carolina e João Antonio, há uma forte aproximação com a oralidade, decorrente do meio em que se fizeram enquanto criadores. Eles abrem pequenas janelas para que possamos enxergar uma outra e quase invisível São Paulo, particularmente oral ou em regiões de intermediação. Criadores desembaraçados que fizeram emergir, de forma mais ou menos intensa, elementos culturais profundos trazidos pelos migrantes e imigrantes, incorporando-os vivamente ao contexto histórico e ferindo o cânone que tentava se estabelecer.

Mais ainda do que uma ligação com a oralidade, as obras desses criadores sem pejo trazem uma forte conotação rítmica que acompanha a cadência cultural das populações moventes com as quais compartilham a ambiência, encantando com palavras, imagens, gestos e rítmos ao mesmo tempo em que se deixavam encantar pela gestualidade, a exuberância e o transbordamento que os cercavam. Elementos esses que eram cada vez mais cooptados pelos meios de entretenimento de massa, especialmente o rádio, 0

\footnotetext{
${ }^{22}$ Sobre a descoberta da importância da oralidade nos anos 50 e 60 cf. Walter J. Ong Orality and Literacy. The Technologizing of the Word, London and New York: Methuen, 1982; Eric Havelock. A Musa Aprende a Escrever. Reflexões sobre a Oralidade e a Literacia da Antiguidade ao Presente, tradução de Maria Leonor Santa Bárbara, Lisboa: Gradiva, 1996 e A Revolução da Escrita na Grécia e suas Conseqüências Culturais, Tradução de Ordep José Serra, São Paulo: Editora da UNESP, Rio de Janeiro: Paz e Terra, 1996.

${ }^{23}$ Para o discurso do desenvolvimento cf. Flávio Ribeiro, op. cit.. Sobre a comemoração ver Sílvio Luis Lofego, op. cit..
} 
cinema, as revistas ilustradas e por fim a televisão que naquele período se inaugurava.

Distanciando-me das posturas da cultura hegemônica do período, pretendo aproximar-me do que Mikhail Bakhtin chamou de o coro popular a rir. Para ele,

Todos os atos do drama da história mundial se desenrolaram diante do coro popular a rir. Sem ouví-lo, é impossível compreender o drama no seu conjunto. ${ }^{24}$

Esse coro popular, invariavelmente dissonante, composto por múltiplas vozes, poucas vezes foi ouvido em relação ao período estudado. Quando se opta pelo trabalho com memórias, são sempre escolhidas as mesmas personalidades para darem seus depoimentos sobre a época. Pertencentes a uma parcela da chamada elite cultural, atuante até hoje e que teve nos anos 50 o seu momento de formação intelectual, compõem um discurso bastante homogêneo. A harmonia da composição, porém, não convence quando se parte para o ritmo da época.

Outro autor que auxilia na busca de um trabalho histórico livre das certezas e verdades absolutas e a caminho da compreensão do passado através da interrogação e do encontro de resultados parciais é o físico-químico Ilya Prigogine, teórico das estruturas dissipativas, das singularidades aleatórias e da irreversibilidade do tempo. Ele nos alerta para o fato de que "Nosso mundo é flutuante, ruidoso, caótico, mais próximo daquele que os atomistas gregos haviam imaginado." 25 A ciência é uma prática cultural, como aponta Prigogine, e que, portanto, está inserida em um contexto, por vezes tendendo, com suas leis e formulações matemáticas ou prisões conceituais, a criar um lago artificial de tranqüilidade, marcado por posicionamentos estáveis, fugindo ao turbilhão expresso pela teoria da complexidade e também pela literatura e pela arte em geral.

Desde Arquimedes e Clausius, a ciência clássica dos fluxos se opõe à ciência das turbulências, das evoluções bifurcantes, à ciência que

\footnotetext{
${ }^{24}$ Mikhail Bakhtin. A Cultura Popular na Idade Média e no Renascimento: o Contexto de François Rabelais, São Paulo: HUCITEC; Brasília: Editora da Universidade de Brasília, 1987, p. 418.

25 Ilya Prigogine. O Fim das Certezas. Tempo, Caos e as Leis da Natureza, São Paulo: Editora da UNESP, 1986, p. .
} 
mostra que, longe dos canais, a perturbação pode fazer nascer as coisas, e a natureza, e os homens. ${ }^{26}$

Para a compreensão da cultura de consumo e entretenimento que se intensificou após a Segunda Guerra Mundial, os estudos de Guy Debord e sua concepção do espetáculo foram de especial importância. Para ele, vivíamos um momento único em que as pessoas estavam sendo preparadas para o consumo, brevemente importariam como consumidores, para logo depois não importarem mais em seu excedente, era um mundo em que o valor de troca superou em muito o valor de uso. ${ }^{27}$

Là ou le monde réel se change em simples images, les simples images deviennent des êtres réels, e les motivations efficientes d'un comportement hypnotique. Le spectacle, comme tendance à faire voir par différentes médiations spécialisées le monde qui n'est plus directemente saississable, trouve normalement dans la vue de sens humain privilégié qui fut à d'autres époques le toucher; le sens le plus abstrait, et le plus mystifiable, correspond à l'abstraction généralisée de la societé actuelle. ${ }^{28}$

Debord, um dos fundadores da Internacional Situacionista no final dos anos 50 , soube interpretar, através de seus textos e filmes, o instante em que vivia de maneira privilegiada, sendo uma referência importante para meu estudo. Levou-me a pensar no cultivo pela publicidade de um desejo amplificado que se esparramou pelo mundo do pós-guerra e que trouxe por conseqüência uma frustração sem limites.

A proposta dos situacionistas era de uma revolução da vida cotidiana através da psicogeografia, do desvio e do urbanismo unitário, criando-se um mundo de experimento, anarquia e jogo, reconstruindo as afetividades urbanas

\footnotetext{
${ }^{26}$ Ilya Prigogine e Isabelle Stengers. A Nova Aliança. A Metamorfose da Ciência, tradução de Miguel Faria e Maria Joaquina Machado Trincheira, Brasília: Editora Universidade de Brasília, 1997, p. 218.

${ }^{27}$ Guy Debord. La Societé du Spetacle, Paris: Gallimard, 1992, pp.40 e 43, teses 43 e 46.

${ }^{28}$ Idem, p. 23, tese 18. Na edição brasileira: "Quando o mundo real se transforma em simples imagens, as simples imagens tornam-se seres reais e motivações eficientes de um comportamento hipnótico. $\mathrm{O}$ espetáculo, como tendência a fazer ver (por diferentes mediações especializadas) o mundo que já não se pode tocar diretamente, serve-se da visão como o sentido privilegiado da pessoa humana - o que em outras épocas fora o tato; o sentido mais abstrato, e mais sujeito à mistificação, corresponde à abstração generalizada da sociedade atual." Cf. A Sociedade do Espetáculo, tradução de Estela dos Santos Abreu.Rio de Janeiro, 1997, p.18.
} 
e promovendo um enriquecimento da participação humana nos mais ínfimos detalhes. $^{29}$

Essa proposta radical permite compreender o quanto o processo de enrijecimento da cidade pela lógica do planejamento burocrático e capitalista afastou, com o decorrer do tempo, os moradores das decisões sobre o espaço e de suas próprias vidas, separando-os inevitavelmente dos outros, delegando a poucos o direito da intervenção, neutralizando as divergências, confundindo homens e coisas. ${ }^{30}$ Mas também, essa proposta permite admitir o quanto esse ideal de libertação e reconfiguração do mundo estava encravado no sonho dos desenraizados, em suas intermináveis derivas pelo "mundaréu", em seus mínimos gestos divergentes.

" 'É pois, no antidestino que moram as coisas do nosso acontecer diário, na reinvenção dos gestos com que ousamos viver. E aí, não tenho dúvida, estão os grandes instantes de ternura, que são os instantes da verdade." "31

\footnotetext{
${ }^{29}$ Sobre as propostas situacionistas para a cidade cf. Simon Sadler. The Situationist City, Cambridge: MIT Press, 1999.

${ }^{30}$ Além dos textos, a filmografia de Guy Debord apresenta elementos importantes para a composição da proposta situacionista. No filme de 1961, Crititique de la Separation, por exemplo, Debord criticando o cinema documentário expôs o processo de embotamento do mundo pela neutralização das divergências e o domínio do entorno.

31 João Antonio revirando trechos de suas cartas. "Ajuda-me a sofrer" in A Dama do Encantado, São Paulo: Nova Alexandria, 1996, p.97.
} 


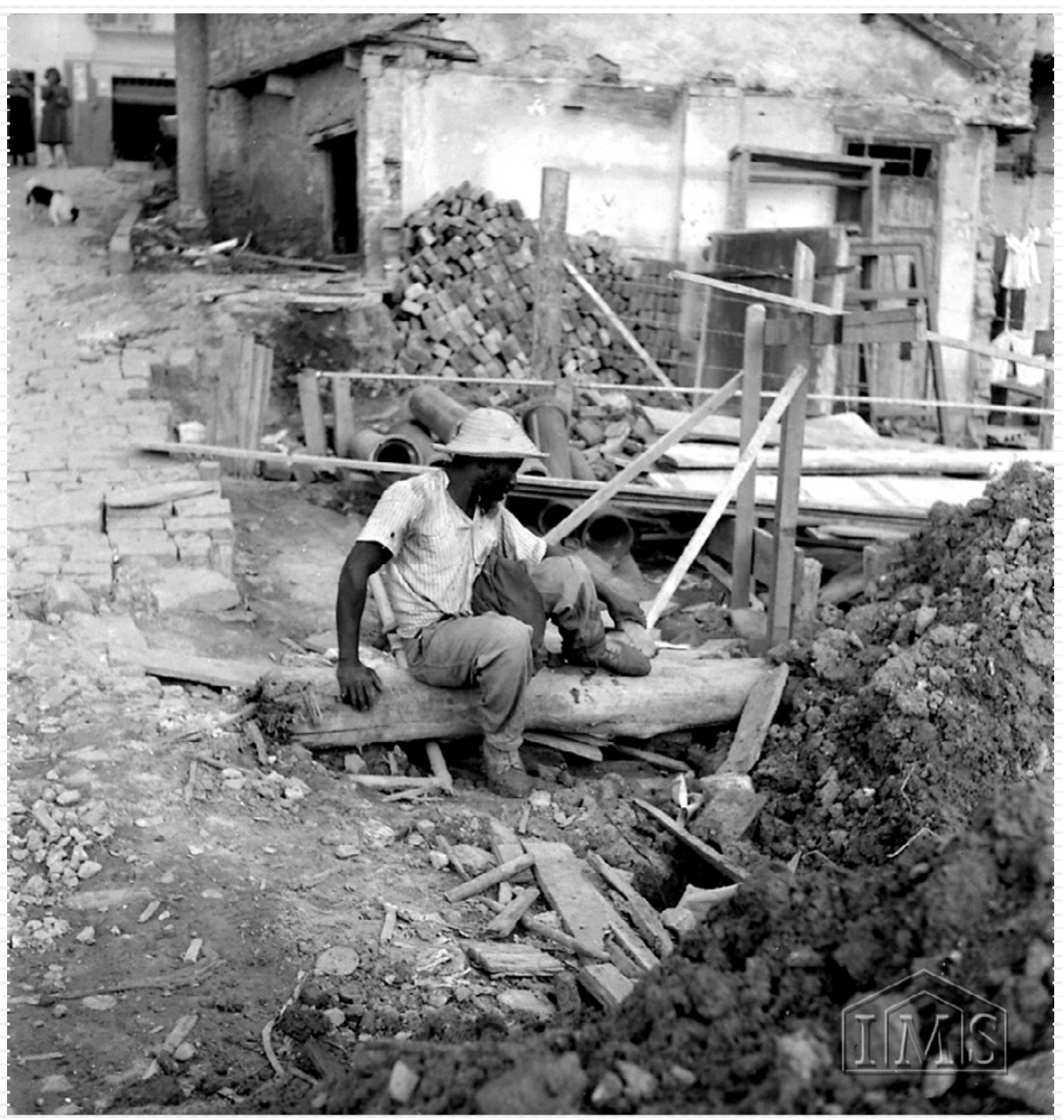




\section{São Paulo, A Cidade Movente}

Les secteurs d' une ville sont, à un certain niveau, lisibles, mais le sens qu'ils ont eu pour nous, personnellement, est intransmissible, comme toute cette clandestinité de la vie privée, sur laquelle on ne possède jamais que des documents dérisoires.

(Guy Debord, Critique de la Séparation, 1961) 


\subsection{Em Busca de um Canto}

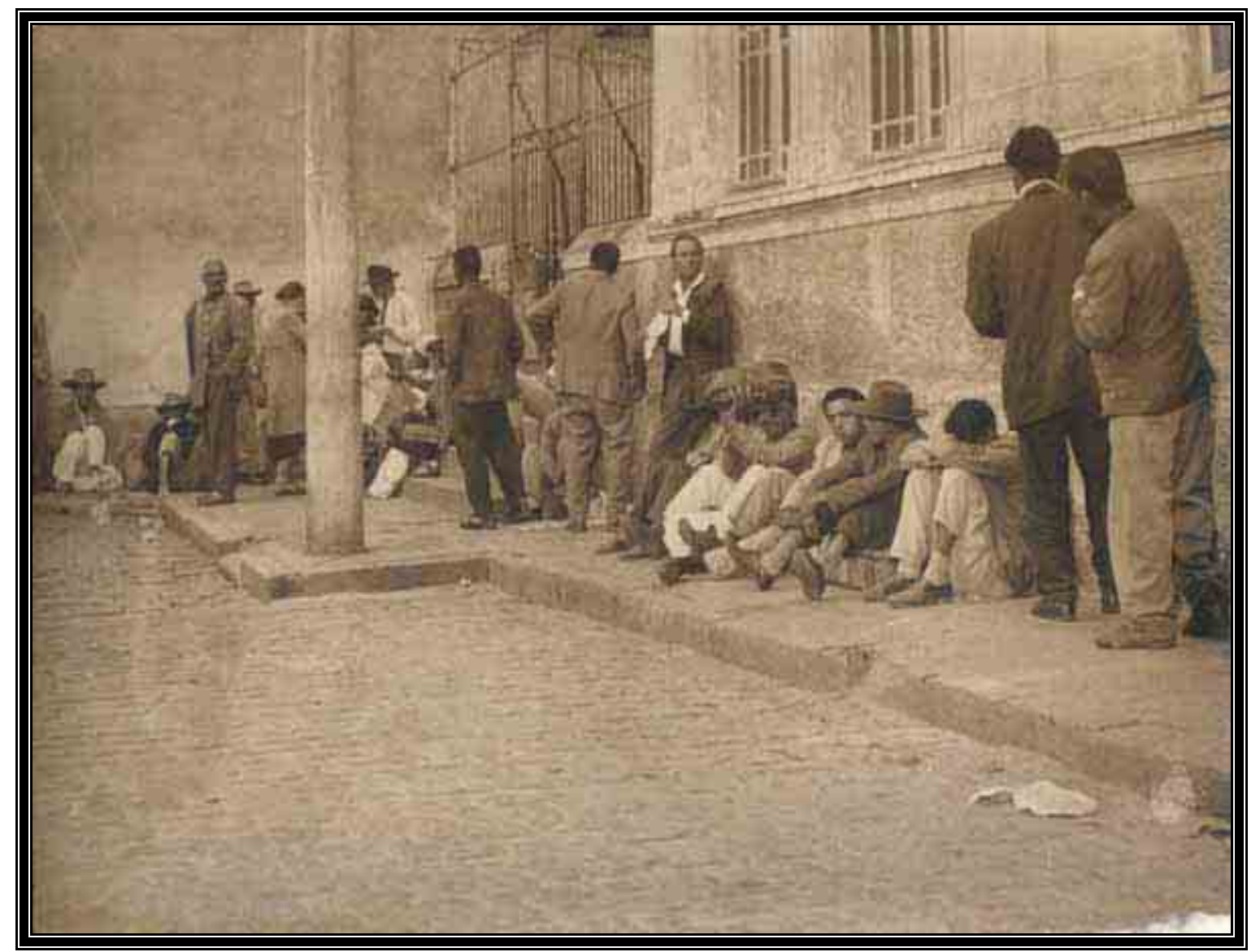

Imagem 1 - Fila na porta de Abrigo da Prefeitura, São Paulo, 1960. Jornal Última Hora, 30/05/60 / Arquivo do Estado de São Paulo. Arquivos Especiais-Iconográfico. Código: ICO-UH 1662 - Assistência Social.

- "O senhor acha que a minha alma eu vendi, pactário?!" Então ele sorriu, o pronto sincero, e me vale me respondeu: - "Tem cisma não. Pensa para diante. Comprar ou vender, às vezes, são ações que são as quase iguais..."

\footnotetext{
${ }^{1}$ João Guimarães Rosa. Grande Sertão: Veredas, 19aed., Rio de Janeiro: Nova Fronteira, 2001, p.623.
} 
Ao chegar nas Veredas Mortas, no meio da escura encruzilhada, lugar que desprendia desespero, Riobaldo, o jagunço andadeiro, antes convicto, tremeu. Mesmo assim, como queria "ficar sendo", esperou. "Eu queria ser mais do que eu. Ah, eu queria, eu podia. Carecia. 'Deus ou o demo?' - sofri um velho pensar." ${ }^{2}$ Qual caminho de fato seguiu? Não se sabe. Nem mesmo ele algum dia soube com toda a clareza, apesar da sensação de prazer aflitivo que dele se apoderou no instante fulcral. O que de certou houve foi a transformação agressiva de sua personalidade. Sua vida inteira, depois, indagou a si mesmo e a todos sobre isso. Fez o pacto? Não fez o pacto? Vendeu a alma ou não?

O romance de Guimarães Rosa, publicado em 1956, em pleno despontar das ações de desbravamento de uma parte do sertão para a construção da capital planejada, Brasília, mais do que, como já foi dito pela crítica, continuou a fórmula dos romances de cavalaria, transplantando-a avessamente para o Sertão. ${ }^{3}$ Em Grande Sertões Guimarães subverteu as normas desses romances, como também das canções de gesta, pois nelas, segundo Auerbach,

O mundo tornou-se muito pequeno e estreito e nele se trata, rígida e inamovivelmente, de uma única pergunta, já respondida de antemão, à qual o homem só deve dar a resposta adequada. Sabe qual o caminho que deve percorrer ou, antes, há um só caminho aberto, não há outros. Também sabe que encontrará uma encruzilhada. Sabe também, finalmente, que então deverá escolher a direita, não obstante o Tentador o alicie para a esquerda. Tudo o mais, a infinita amplidão do mundo exterior e do interior, com o seu sem-número de possibilidades, imagens e camadas, tudo está submerso. ${ }^{4}$

Nos romances de cavalaria, mesmo se tratando de "um mundo muito mais rico, muito mais cheio de variedade, mais pleno do que o mundo das chanson de geste, (...)" também se espera que o cavaleiro que saiu em busca de aventuras pegue o caminho à direita.

Por que à direita? Sentido moral, é o caminho certo, penoso, que conduz à meta certa: um castelo onde é recebido com alegria. ${ }^{6}$

\footnotetext{
${ }^{2}$ Rosa, idem, p. 437.

${ }^{3}$ Antônio Candido. "O Homem dos Avessos", in Tese e Antitese. Ensaios, $4^{\mathrm{a}}$ ed., São Paulo: T.A.Queiroz Editor, 2000, pp. 119-139.

${ }^{4}$ Erich Auerbach. Mimesis. A Representação da Realidade na Literatura Ocidental, $5^{\mathrm{a}}$ ed., São Paulo: Perspectiva, 2004, p.97.

${ }^{5}$ Auerbach, idem, p. 115.

${ }^{6}$ Auerbach, idem, p.112.
} 
Ao optar pela esquerda, sem ao menos poder certificar-se de qual direção efetivamente tomou, Riobaldo não se libertou da confusão do mundo como era o seu desejo e talvez como ocorreria se o da direita tivesse tomado. O sem-número de possibilidades, imagens e camadas estavam em profusão. Ele, contudo, pretendia que os papéis estivessem traçados previamente, que houvessem leis determinando e controlando tudo. ${ }^{7}$

Ah, porque aquela outra é a lei, escondida e vivível mas não achável, do verdadeiro viver: que para cada pessoa, sua continuação, já foi projetada, como o que se põe, em teatro, para cada representador - sua parte, que antes já foi inventada, num papel... ${ }^{8}$

Pelo contrário, essa confusão emergia a todo instante em suas andanças, trazendo de volta o tempo irremediável e irreversível que ele não queria aceitar e que, quando aceito, ao final do romance, marcado em uma folhinha de parede, o fez sentir-se como um "saco de pedras", um sedentário. ${ }^{9}$

Tempo? Se as pessoas esbarrassem, para pensar - tem uma coisa! - : eu vejo é o puro tempo vindo de baixo, quieto mole, como a enchente duma água... Tempo é a vida da morte: imperfeição. Bobices minhas - o senhor em mim não medite. ${ }^{10}$

O tempo insistia em se fazer sentir nas pequeninas coisas e perturbava Riobaldo por lançar os homens na incerteza do acaso e na inconstância, tornando o viver arriscado e perigoso, dissolvendo sua individualidade: "o montante movimento do mundo me delia, igual a um secar." 11

\footnotetext{
${ }^{7}$ Pode-se lembrar aqui a similar vontade de ordenação e controle presente na obra de Arthur Bispo do Rosário, com seu encadeamento de objetos e palavras, inscrições para registrar o mundo. Cf. José Roberto Alves Olmos Fernandez. A Condição Paradoxal da Obra de Arthur Bispo do Rosário, dissertação de mestrado em Filosofia, FFLCH-USP, 2000.

${ }^{8}$ Rosa, Grande Sertão: Veredas, op. cit., p. 500.

${ }^{9}$ Rosa, idem, p. 618.

${ }^{10}$ Rosa, idem, p. 603. Sobre a concepção mítica e circular do tempo e sua anteposição ao tempo histórico e irreversível ver Reginaldo Prandi. Segredos Guardados. Orixás na Alma Brasileira, São Paulo: Companhia das Letras, 2005, p.32.

${ }^{11}$ Rosa, idem, p.507.
} 
No momento em que Guimarães escrevia a saga de Riobaldo, o indeterminismo e a assimetria do tempo arraigavam-se na ciência. ${ }^{12}$ Segundo o físico-químico llya Prigogine, teórico da complexidade e um dos principais responsáveis por essas discussões a partir da década de 50 , as noções de estruturas dissipativas, crise $\mathrm{e}$ instabilidade, atingiram a Física não independentemente da forma como atingiram a cultura contemporânea. ${ }^{13} \mathrm{~A}$ ciência começou a trilhar com o estudo dos sistemas distantes do equilíbrio um caminho estreito entre "as leis cegas e os eventos arbitrários", procurando um espaço para a criatividade, espaço esse ligado a um tempo futuro aberto e indeterminado. $^{14}$

Encontramo-nos num mundo irredutivelmente aleatório, num mundo em que a reversibilidade e o determinismo figuram como casos particulares, em que a irreversibilidade e a indeterminação microscópicas são regra. $^{15}$

A unidade complexa exigia a abertura, a imprevisibilidade, o trato com o tempo criativo, a perda do controle, da linearidade, da trajetória, mas tendo como ganho maior a vida que se dá pelas flutuações, pelas bifurcações, pela entropia. E não mais aceitava uma idealização racionalista da realidade como aquela proposta a partir das leis newtonianas, muito mais próximas do registro imaginoso da alquimia do que muitas vezes se quis supor. ${ }^{16}$ Nesse contexto, as demandas do jagunço Riobaldo eram indefinidas e misturadas como suas lembranças que jorravam em roldão. ${ }^{17}$

\footnotetext{
${ }^{12}$ Ilya Prigogine e Isabelle Stengers. O Fim das Certezas. Tempo, caos e as leis da natureza, tradução de Roberto Leal Ferreira, 3. ${ }^{a}$ ed., São Paulo: Editora da Universidade Estadual Paulista, 1996, p.23.

${ }^{13}$ Ilya Prigogine e Isabelle Stengers. A Nova Aliança. A Metamorfose da Ciência, tradução de Miguel Faria e Maria Joaquina Machado Trincheira, Brasília: Editora Universidade de Brasília, 1997, p.138.

${ }^{14}$ Ilya Prigogine e Isabelle Stengers. O Fim das Certezas, op. cit., p.199. Sobre a criatividade do tempo, cf. Ilya Prigogine. O Nascimento do Tempo, tradução de João Gama, Lisboa: Edições 70, 1991.

${ }^{15}$ Ilya Prigogine e Isabelle Stengers, A Nova Aliança, op. cit., p. 8.

${ }^{16}$ Sobre a tentativa dos socialistas utópicos de enquadrarem a realidade num esquema ordenado de leis, cf. Guy Debord, A Sociedade do Espetáculo, op. cit., tese 83. Sobre as relações de Newton com a alquimia cf. Ilya Prigogine e Isabelle Stengers, A Nova Aliança, op. cit..

${ }^{17}$ Segundo Heitor Megale, "Por definição, toda demanda é uma aventura longamente contrariada, o que provoca, ao longo de sua realização, uma errância." A Demanda do Santo Graal. Das Origens ao Códice Português, São Paulo: Ateliê Editorial / FAPESP, 2001, p. 42.
} 
o mais difícil não é um ser bom e proceder honesto; dificultoso, mesmo, é um saber definido o que quer, e ter o poder de ir até no rabo da palavra. ${ }^{18}$

Sem saber exatamente o que queria, queria sua vida governada por seu querer. "Eu queria minha vida própria, por meu querer governada."19 E compreender sua própria vontade, que dominaria sua existência, parecia ser sua maior demanda. ${ }^{20}$

Comme les yeux regardent beaucoup de choses confusément et ne peuvent voir distinctement aucune, de même, la volonté qui imparfaitement tend à divers objets et ne peut parfaitement n'en aimer qu'une à la fois. ${ }^{21}$

Apegada ao contexto em que foi escrita, a história do jagunço Riobaldo revela as perturbações de um momento histórico em que se poderia evocar o canto de Dante como o fez Guy Debord:

A la moitie du chemin de notre vie, je me retrouvait dans une forêt obscure oú la droite voie était perdue. ${ }^{22}$

O sentido da escolha invertia-se após a Segunda Guerra, quando a pujança de um mundo de múltiplas imagens impostas e espalhadas sobrepunha-se ao pensamento fantástico, não permitindo mais aqueles que se movimentavam a opção do caminho ancestralmente indicado como o mais correto. Esse novo contexto exigia por um lado, a afirmação do indivíduo pensante, dono de sua própria vontade, capaz de forjar novas direções além da esquerda ou da direita, e, por outro, o soltar-se sem amarras no fluxo do tempo, trazendo sempre como perigo, por contágio, a submersão na

\footnotetext{
${ }^{18}$ Rosa. Grande Sertão: Veredas, op. cit., p.190.

${ }^{19}$ Rosa, idem, p. 370 .

20 "A demanda mais do que a busca de um objeto pode ser a busca de um significado, um significado oculto. Cf. Megale, op. cit., p.42.

${ }^{21}$ Guy Debord. Sur lê passage de quelques personnes à travers une assez courte unité de temps, filme de 1959.

${ }^{22}$ Guy Debord utilizou, em 1961, em seu filme Critique de la Separation, os versos de abertura do Inferno de Dante Alighieri. Na tradução de Cristiano Martins: "A meio caminho desta vida, achei-me a errar por uma selva escura, longe da boa via, então perdida." A Divina Comédia. Primeiro Volume. Inferno, $2^{\mathrm{a}}$ ed., São Paulo: EDUSP / Itatiaia, 1979, p.101.
} 
uniformidade conformista da cultura de consumo, revestida de uma falsa diversidade. É ainda Guimarães quem nos indica as duas alternativas expostas através de personagens exemplares, provenientes da cultura popular: o primeiro deles é Augusto Matraga, de "A hora e vez", texto publicado em 1946. Matraga é aquele que se deixou conduzir por um moar, "animalzinho assim meio sagrado" que, por sua vez, escolhia o caminho ao acaso. ${ }^{23} \mathrm{O}$ valente seguia pacientemente acreditando que nesse mundo tudo acontece em seu devido e marcado tempo e um dia, inevitavelmente, a justiça se fará:

E bastava batesse no campo o pio de uma perdiz magoada, ou viesse do mato a lália lamúria dos tucanos, para o jumento mudar de rota, pendendo à esquerda ou se empescoçando para a direita; e, por via de um gavião casaco-de-couro cruzar-lhe à frente, já ele estacava, em concentrado prazo de irresolução. ${ }^{24}$

O segundo é Riobaldo, incansável empreendedor de pensamentos, buscando desesperadamente enfeixar sua decisão no âmbito de sua livre vontade, tentado compreender porque outros se lançavam na vida intensamente, o que os impedia de optar.

E por que era que há de haver no mundo tantas qualidades de pessoas - uns já finos de sentir e proceder, acomodados na vida, tão perto de outros, que nem sabem de seu querer, nem da razão bruta do que por necessidades fazem e desfazem. Por quê? (...) E de repente aqueles homens podiam ser montão, montoeira, aos milhares mês e centos milhentos, vinham se desentocando e formando, do brenhal, enchiam os caminhos todos, tomavam conta das cidades. Como é que iam saber ter poder de serem bons, com regra e conformidade, mesmo que quisessem ser? Nem achavam capacidade disso. Haviam de querer usufruir depressa de todas as coisas boas que vissem, haviam de uivar e desatinar. ${ }^{25}$

A luta de Riobaldo e Matraga nos sertões era a luta que se aplicava cotidianamente a todos os que habitavam os grandes centros urbanos e não se conformavam com a condição de mesmice e acato que ameaçava concretizarse, neutralizando as "emoções divergentes" e criando um ambiente de enganadora harmonia, onde o espaço, regulado pelo urbanismo planejador,

\footnotetext{
${ }^{23}$ João Guimarães Rosa“A hora e vez de Augusto Matraga”, op. cit., p. 401.

${ }^{24}$ Rosa, idem , p.404.

${ }^{25}$ Rosa, Grande Sertão: Veredas, op. cit., pp. 405-6.
} 
impunha-se sobre o tempo inquieto e criava a ilusão de um falso tempo cíclico e de uma falsa coletividade. ${ }^{26}$

Eu tinha enjôo de toda pasmacêz. ${ }^{27}$

Se nos centros capitalistas mais avançados essa luta estava relegada à periferia e aos grupos marginalizados, eclodindo por vezes em movimentos de conturbada e explosiva aparição, em cidades como São Paulo ela era perfeitamente discernível no dia-a-dia em praticamente todos os pontos da cidade, dada a inconsistência da modernização, a alta desigualdade social e a incoerência das decisões políticas tomadas. ${ }^{28}$

eu toda a minha vida pensei por mim, forro, sou nascido diferente. Eu sou é eu mesmo. Divêrjo de todo mundo... ${ }^{29}$

Afirmar-se como indivíduo, quando se perdeu o conforto da comunidade, exigia a redescoberta de seu próprio desejo, exigia o cumprimento de uma demanda e, muitas vezes, exigia, como para Matraga, a retomada do sonho primevo, cantando pelos caminhos, na tentativa de estabelecer nexos com os sentidos comunitários que insistiam em se perder. ${ }^{30}$

- Adeus, minha gente, que aqui é que mais não fico, porque a minha vez vai chegar, e eu tenho que estar por ela em outras partes! - Espera o fim das chuvas, meu filho! Espera a vazante... - Não posso, mãe

\footnotetext{
26 "Les émotions divergentes se neutralisent y maintiennent leur solide environnement d'ennui." Guy Debord, Critique de la Separation, filme de 1961. Nesse mesmo filme, como também em seu livro A Sociedade do Espetáculo, op. cit., Debord aborda a questão da separação entre os homens, que não mais se reconhecem a não ser pelas coisas. Guimarães Rosa, por sua vez, põe no pensamento de Manuelzão, o protagonista de "Uma história de amor", a seguinte reflexão: "Trabalhar é se juntar com as coisas, se separar das pessoas." João Guimarães Rosa. "Uma estória de amor (Festa de Manuelzão)" in Manuelzão e Miguilim (Corpo de Baile), $11^{\mathrm{a}}$ ed., Rio de Janeiro: Nova Fronteira, 2001, p. 194. (1 $1^{\mathrm{a}}$ ed. 1956). Sobre a relação tempo e espaço, cf. Guy Debord, A Sociedade do Espetáculo, op. cit., teses 170 e 172.

${ }^{27}$ Rosa, Grande Sertão: Veredas, op. cit., p. 442.

${ }^{28}$ Sobre as explosivas sublevações da população negra no bairro de Watts em Los Angeles em 1965 ver Guy Debord. "O declínio e a queda da economia espetacular mercantil", op. cit..

${ }^{29}$ Rosa, Grande Sertão Veredas, op. cit., p. 31.

${ }^{30} \mathrm{O}$ destino de uma aventura pode ser revelar se o herói é digno de ser recebido por uma comunidade. Cf. Heitor Megale, op. cit., p.43. Antônio Candido, por ocasião de sua pesquisa em 1948 e 1954 na região de Bofete, interior de São Paulo, constatou que na poesia popular manifestada no Cururu, dança cantada dos caipiras paulistas, houve uma mudança de padrões privilegiando cada vez mais o individualismo e a secularização, "desaparecendo inclusive o elemento coreográfico socializador, para ficar o desafio na sua pureza de confronto pessoal." Antônio Candido. Os Parceiros do Rio Bonito. Estudo sobre o Caipira Paulista e a Transformação dos seus Meios de Vida, $7^{\mathrm{a}}$ ed., São Paulo: Livraria Duas Cidades, 1987, p.9.
} 
Quitéria. Quando o coração está mandando, todo tempo é tempo!...E, se eu não voltar mais, tudo o que era de meu fica sendo para vocês. ${ }^{31}$

Cantar, só não fazia mal, não era pecado. ${ }^{32}$

Para que eu carecia de tantos embaraços? Pois os próprios antigos não sabiam que um dia virá, quando a gente pode permanecer deitada em rede ou cama, e as enxadas saindo sozinhas para capinar roça, e as fôices, para colherem por si, e o carro indo por sua lei buscar a colheita, e tudo, o que não é o homem, é sua, dele, obediência? ${ }^{33}$

Contra esse sonho trabalhava a marcação do tempo cronológico, a noção exata de passado, presente e futuro, a preponderância das coisas, a afirmação do progresso e da irreversibilidade que deixava para trás aqueles que não os acompanhassem.

Guimarães voltou-se para o universo de encantamento, buscando no sertão um desvio do discurso hegemônico que nas grandes cidades dominava e apontava para um mundo tecnicista e planejado. Deu voz a personagens de extração popular, pois percebia, sendo ele um mediador, que as camadas de cultura antes mais ou menos preservadas pela relativa independência, começavam a se transformar cada vez mais rapidamente e de maneira desestruturante pelo contato com novas dimensões de cultura antes apenas vislumbradas. ${ }^{34}$ Assim demonstra o personagem Soropita que chegava sempre à pequena cidade de Andrequicé para comprar e saber diversas coisas, entre elas ouvir no rádio o último capítulo da novela para depois repetir aos moradores do povoado do Ão.

Mais exato ainda era dizer a continuação ao Fraquilim Meimeio, contador, que floreava e encorpava os capitulos, quanto se quisesse: adiante quase cada pessoa saía recontando, a divulga daquelas estórias do rádio se espraiava, descia a outra aba da serra, ia à beira do

\footnotetext{
${ }^{31}$ Rosa. “A Hora e Vez de Augusto Matraga”, op. cit., p. 401.

${ }^{32}$ Rosa, idem, ibidem. Pode-se lembrar aqui dos cantos dos caminhos entoados pelos aborígenes australianos e seu universo de encantamento. Bruce Chatwin. Les Chants des Pistes, op. cit.

${ }^{33}$ Rosa. Grande Sertão: Veredas, op. cit., p.522.

${ }^{34}$ Essa penetração do modo de vida urbano nas regiões mais afastadas foi percebida, no tocante aos modos de sobrevivência, por Antônio Candido. Ele escreveu: "O homem rural depende, portanto, cada vez mais da vila e das cidades, não só para adquirir bens manufaturados, mas para adquirir e manipular os próprios alimentos."Antônio Candido. Os Parceiros do Rio Bonito, op.cit., p.142.
} 
rio, e, boca e boca, para o lado de lá do São Francisco se afundava, até em sertões. ${ }^{35}$

Nas histórias de Guimarães Rosa há sempre, porém, um reencantamento de tudo o que vinha de fora, mas não se sabia até quando essa tática cultural persistiria dada a velocidade de penetração dos novos recursos e discursos e a destruição do ambiente em que aquelas culturas se formaram. A saída, muitas vezes, foi procurar um canto em outro lugar, para nele depositar a afetividade e viver novamente o encantamento. ${ }^{36}$

A obra literária de Guimarães é crucial para o entendimento de muitas das principais questões culturais que estavam em debate em meados do século $X X$, e que são de direto interesse para o estudo das populações moventes em São Paulo, entre elas pode-se aqui destacar: o transbordamento da cultura de consumo, as migrações e suas interfaces culturais, o isolamento e fragilidade do indivíduo pensante, a aparente anulação das divergências, o aprisionamento do desejo pela publicidade, o solapamento da cultura tradicional pelos deslocamentos, devastações ambientais e pelo acesso aos meios de informação de massa, a transfiguração da cultura popular com o aproveitamento de todos os resíduos produzidos pela industrialização, o acesso das camadas populares aos recursos da leitura e da escrita, a reconfiguração do sagrado pela incorporação de novos elementos urbanos, o paradigma da libertação através do movimento. ${ }^{37}$

A partir da escrita desviante de Rosa, com seus volteios e deslocamentos de perspectiva, pode-se pegar um atalho para chegar ao vale, espaço do encantamento, e afinar a sensibilidade para se ouvir o canto. Foi isso o que pretendi fazer, tentando acompanhar a movimentação.

\footnotetext{
${ }^{35}$ Rosa. "Dão-Lalalão (O Devente)" in No Urubuquaquá, no Pinhém (Corpo de Baile), 9a ed., Rio de Janeiro: Nova Fronteira, 2001, p.30 (1 ${ }^{\mathrm{a}}$ ed. 1956).

${ }^{36}$ Esse canto pode ser visto como algo semelhante ao "pedaço", definido por José Guilherme Cantor Magnani,“o 'pedaço' é o lugar dos 'colegas', dos 'chegados.." Cf. Festa no Pedaço. Cultura Popular e Lazer na Cidade, São Paulo: HUCITEC / UNESP, 1998, p.12.

${ }^{37}$ Entre diversos autores que debateram ou se inspiraram nesses temas no pós guerra e que foram importantes neste trabalho estão: Guy Debord e todo grupo ligado à Internacional Situacionista, como Raoul Vaneigem, Mustafha Khayati e Asger Jorn; Adorno e Horkheimer; Erick Havelock e Walter Ong; Paulo Freire; Herbert Marcuse; Hannah Arendt; Simone Weil; Michel de Certeau, o antropólogo Jean Rouch, o escritor Albert Camus, Frantz Fanon.
} 


\title{
1.2. No Vale das Borboletas o Canto dos Encantados ${ }^{1}$
}

\author{
O Vale das Borboletas \\ tinha uma beleza sem fim \\ era verde, era florido \\ com cravo, rosa e jasmim \\ tinha de todas as flores \\ naquele imenso jardim.
}

(Abraão Batista.O Vale das Borboletas. Cordel)

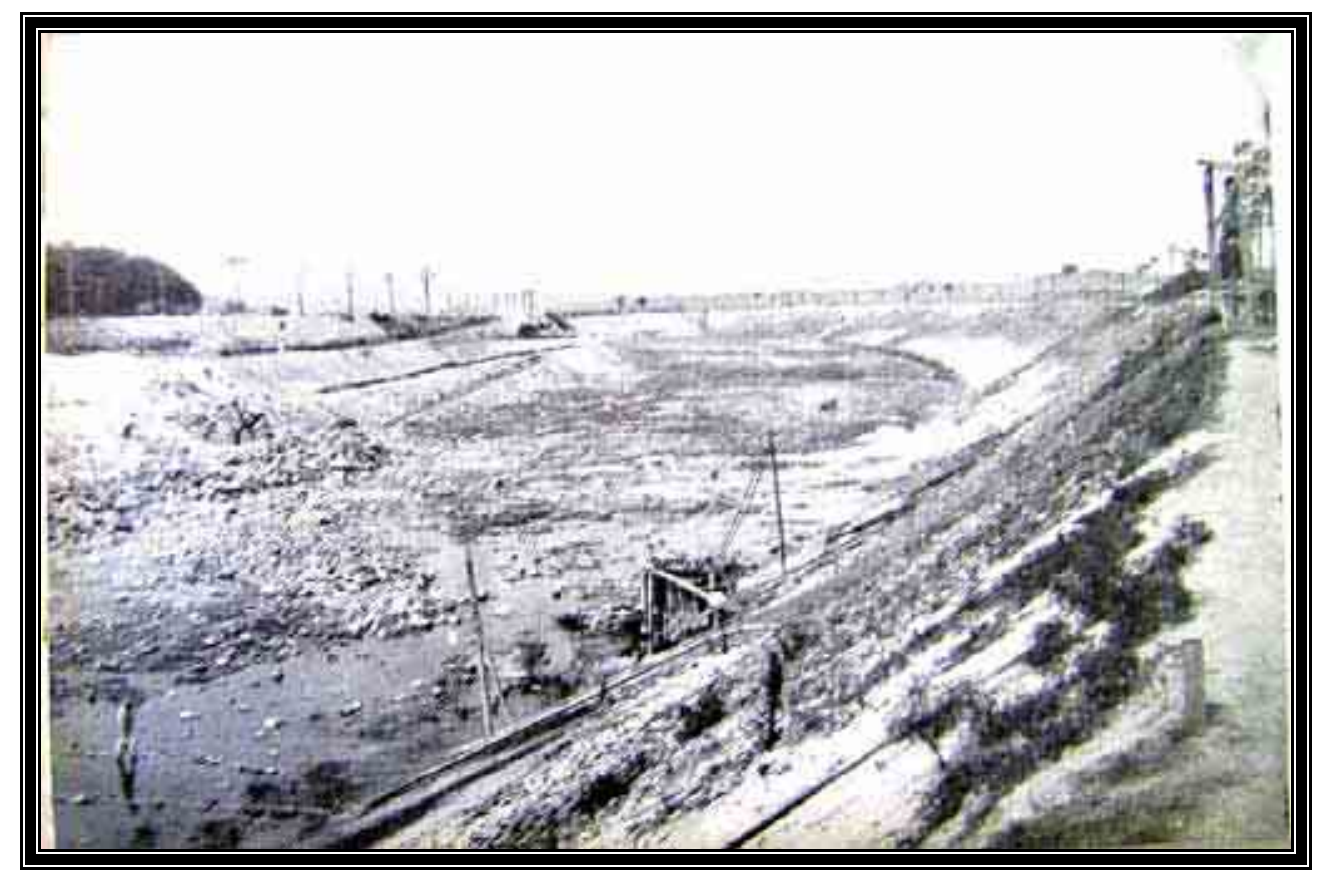

Imagem 2 - "Canalização do Rio Tietê".

Revista Paulistânia, no 9, 1940.

Hei de conhecer a cidade de São Paulo. O povo dizia que era a cidade favo de mel. Em São Paulo tem um bairro que se chama Paraíso. E a cidade de São Paulo é um paraíso para os pobres. É o estado do Brasil que tem mais estradas de ferro. ${ }^{2}$

\footnotetext{
${ }^{1}$ A idéia do título deste capítulo surgiu a partir de uma aula do professor Nicolau Sevcenko sobre o cordel "A história do príncipe Ribamar e o Vale das Borboletas". A esse vale encantado, presente no imaginário nordestino e com conotações ibéricas e medievais, procurei unir referências à cultura dos encantados, entidades que habitam um mundo místico e invisível na religiosidade afro-indígena-brasileira. Cf. Reginaldo Prandi. Encantaria Brasileira. O Livro dos Mestres, Caboclos e Encantados, São Paulo: Pallas, 2001.

${ }^{2}$ Carolina Maria de Jesus. Diário de Bitita, Rio de Janeiro: Nova Fronteira, 1986, p.177.
} 
Eu via várias pessoas irem para São Paulo e pensava: 'Há de chegar a minha vez.' "3

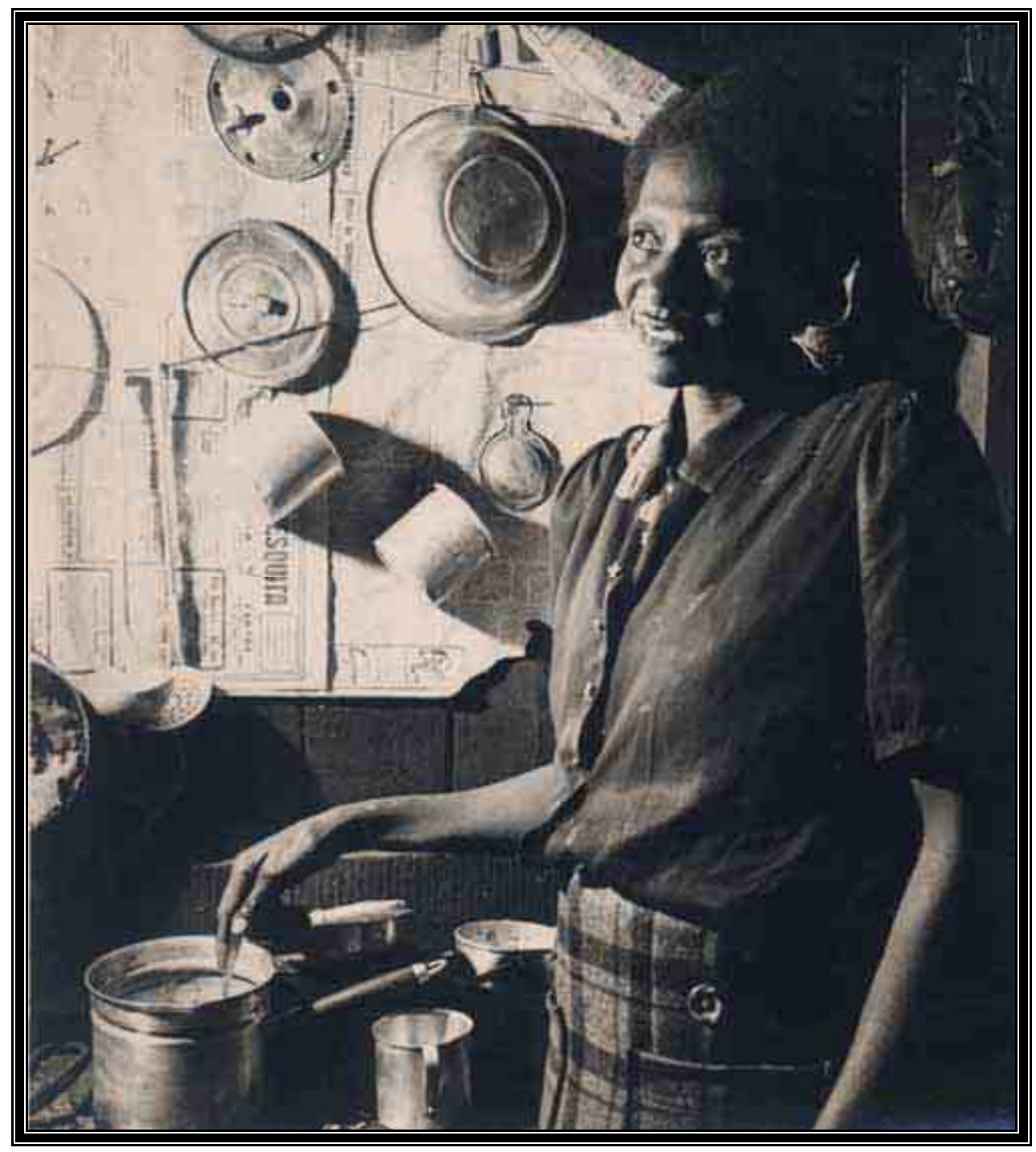

Imagem 3 - Carolina Maria de Jesus em seu barraco na Favela do Canindé, 1952. Jornal Última Hora, 9/07/1952. Foto: Norberto / Arquivo do Estado de São Paulo. Arquivos Especiais-Iconográfico. Código: ICO-UH-0369-Carolina Maria de Jesus.

Carolina Maria de Jesus nasceu na pequena cidade mineira de Sacramento, segundo ela mesma, em 1914 ou $1921 .{ }^{4}$

\footnotetext{
${ }^{3}$ Jesus, Idem, p.188.
} 
No dia 27 de agosto de 1927 o vovô faleceu. Minha mãe disse-me que eu estava com seis anos. Será que eu nasci no ano de 1921? Há os que dizem que nasci no ano de $1914 .^{5}$

Seu sonho desde a mais tenra idade foi viver em uma terra de fartura e abundância, em contraposição à dura vida que levava morando com sua mãe e seu meio irmão. Carolina ou Bitita, como era chamada pelos seus, não conheceu seu pai, mas conheceu uma série de privações ao lado da mãe que sustentava a família lavando roupas nas casas dos ricos. ${ }^{6}$

A nossa casinha era recoberta de sapé. As paredes eram de adobe cobertas com capim. (...) O chão não era soalhado, era de terra dura, condensada de tanto pisar. ${ }^{7}$

Menina atenta ao que se passava ao redor e pouco afeita às brincadeiras infantis, Carolina desde muito cedo soube captar como poucos a vibração do seu meio: angústias, aflições, medos, deslumbramentos, sonhos, desejos, cores, cheiros, gestos, detalhes, opiniões, sabedorias, preconceitos, mercadorias, fé, felicidade e tristeza. Tudo lhe chegava misturado, sem ordenação, insuflando seu querer.

Se eu me encontrasse com Deus ia pedir-lhe: 'Deus, dá o mundo para mim? 8

\footnotetext{
${ }^{4}$ A obra e a vida de Carolina Maria de Jesus foi pouco estudada no Brasil, apesar da repercussão internacional de seu diário Quarto de Despejo. Como referência pode-se citar o trabalho dos professores José Carlos Sebe Bom Meihy e Robert Levine que, com a ajuda de um grupo de alunos pesquisadores, tiveram a oportunidade de entrevistar os filhos de Carolina e pessoas que com ela conviveram. Tiveram acesso também aos manuscritos de Carolina, em sua grande parte inéditos, que se encontram hoje sob a guarda da Biblioteca Nacional do Rio de Janeiro, onde foram microfilmados através de um convênio com a Library of Congress em Washington. O resultado dessa pesquisa foi publicado no livro Cinderela Negra. A Saga de Carolina Maria de Jesus, Rio de Janeiro: UFRJ, 1994. Os professores Sebe e Levine também são os responsáveis pela edição de trechos inéditos do diário de Carolina no livro Meu Estranho Diário. São Paulo, Xamã, 1996. Além disso, Sebe Bom Meihy organizou e publicou as poesias de Carolina em Antologia Pessoal, Rio de Janeiro: Editora UFRJ, 1996.

${ }^{5}$ Jesus, Idem, p. 120.

${ }^{6}$ Jesus, idem, pp. 7-8. Segundo Ily Prigogine, o poeta Paul Valéry tinha um grande sentimento de espanto, assombro por existir, para ele a existência não era algo de evidente, dada, o fato de existir era algo assombroso. Cf. Ilya Prigogine. "L'actualité de la conception du temps chez Valéry" in ROBINSONVALÉRY, Judith. Fonctions de l'Esprit. Treize Savants Redécouvrent Paul Valéry, Paris: Presses Universitaires de France, 1983, p. 259.

${ }^{7}$ Jesus, Idem, p. 7.

${ }^{8}$ Jesus, idem, p. 16.
} 
O seu "olhar circulador" através das vidraças, como ela mesma dizia, registrava como uma câmera os movimentos da vida dos que the eram impostos como patrões por serem brancos e detentores do capital que "aprisionava" os pobres e negros. Observando a abundância, teve noção clara da escassez. ${ }^{9}$

Que vontade de morar numa rua calçada e com luz elétrica. Mas as ruas que eram calçadas, iluminadas, eram para os ricos. A luz dos pobres eram as lamparinas a querosene e o ferro a carvão. ${ }^{10}$

Queria plantar lavouras. Queria ser um homem forte e comprar um Ford. (...)

Eu invejava as meninas brancas que usavam vestidos de veludo, linho, organdi, e calçavam os pés com meias de seda. ${ }^{11}$

- Se eu pudesse comprar isto! Se eu pudesse comprar aquilo! ${ }^{12}$

Em seu cérebro gravava fragmentos os mais diversos: rezas, frases de Rui Barbosa lidas no jornal por um vizinho, ditos populares, reclamações, histórias, impropérios, tudo. Tinha consciência de seu gosto por colecionar pensamentos: "O meu cérebro anotava tudo que eu ouvia, sem esforço."13

Seu comportamento apreensivo e curioso fazia com que seus vizinhos e parentes a considerassem às vezes como perturbada, mas Carolina mostrava apenas o seu assombro com o mundo e a vida, buscando um lugar para depositar sua afetividade. ${ }^{14}$

Minha mãe disse que não ia deixar eu ir ouvir as leituras do senhor Manoel Nogueira, que eu estava ficando louca. Aconselhou-me a ir brincar com as bonecas. Fui brincar. Não senti atração. Não me emocionei. Não poderia viver tranqüila neste mundo, que é semelhante

\footnotetext{
${ }^{9}$ Jesus, idem, p. 27.

10 Jesus, idem, p. 80.

${ }^{11}$ Jesus, idem, pp. 94-5.

12 Jesus, idem, p. 54.

13 Jesus, idem, p. 32.

${ }^{14}$ Jesus, idem, p. 21.
} 
a uma casa em desordem. Oh! Se me fosse possível lutar para deixá-lo em ordem! $!^{15}$

A cultura oral que cercava Carolina e que atingia seu ápice nas histórias maravilhosas contadas por seu avô, um ex-escravo insatisfeito por nenhum dos seus oito filhos terem aprendido a ler, estava entremeada pelas leituras sobre Rui Barbosa do senhor Manoel Nogueira e os dois anos em que passou na escola espírita Alan Kardec. Nesse período conseguiu alfabetizar-se e passou a ter uma profunda ligação com os livros, "a única coisa que eu venerava."

Seu contato com o universo religioso era mesclado e se fez através dos ensinamentos da escola espírita, da observação de seu avô rezando o terço para chover, das benzeduras de Maria Treme-Treme e do senhor José cego que invocava a Estrela formosa, das romarias e rituais das mulheres pedindo chuva, das invocações de santo Antonio para o aparecimento dos que estavam sumidos, da crença local de que falava por intermédio de um espírito, de suas visões, da vida dos santos que leu nos livros, das congadas em tributo a são Benedito. Desde muito cedo aprendera a colher raízes para curar seus males e também a rogar pragas nos fazendeiros que os exploravam. No dia de sua crisma:

As velas estavam acesas. Os que entravam na igreja levavam flores. $E$ a fusão de cores alegrava o templo santo. O perfume do incenso e das flores mesclava-se. Aquilo para mim era um deslumbramento. ${ }^{17}$

Carolina, como outras tantas crianças, partilhou as experiências de uma pequena cidade interiorana fincada em profundas camadas de hierarquia e de privilégio e acometida por valores inerentes a uma cultura de consumo que se instalava. O existir cada vez mais se resumia ao ter, mas ainda persistiam elementos da exuberância, no sentido de copiosidade e de entusiasmo, infiltrados nas cerimônias, nas festas, nas danças, na poesia, nos relatos, na

\footnotetext{
${ }^{15}$ Jesus, idem, p. 51. O senhor Manuel Nogueira, segundo Carolina, era um oficial de justiça, mulato, que, na porta de sua casa, lia todas às tardes, para quem quisesse ouvir, as notícias do jornal $O$ Estado de São Paulo.

${ }^{16}$ Jesus, idem, p. 128.

${ }^{17}$ Jesus, idem, p. 15.
} 
gostosura das frutas apanhadas no pé, na beleza das cores dos tecidos, no samba, na emoção de desvendar o código escrito, no carinho reservado aos livros. ${ }^{18}$ Havia uma tensão entre a esfera da economia e do desperdício e foi dentro dessa tensão que Carolina se criou.

Com sua família aprendeu que era necessário adquirir terras para ter sossego e ser dona de sua própria vida, fugindo do mandonismo dos fazendeiros intransigentes que ainda os tratavam como escravos, mas também aprendeu como eram importantes os momentos reservados à festa e aos bailes de final de semana, período reservado ao dispêndio do dinheiro ganho com muita dificuldade. Carolina almejava um bom emprego para comprar roupas, passear, ir ao cinema, ser admirada, da mesma maneira que não suportava a disciplina sem o sonho. Entretanto, sabia que os negros praticamente não tinham acesso à educação formal e eram constantemente desrespeitados pelos patrões e pelas autoridades, o que complicava qualquer tentativa de melhorar sua condição social. ${ }^{19}$ A eles estavam reservados os trabalhos mais penosos como lembranças da escravidão.

Eu era louca por terras. Invejava os que tinham terras para plantar. Compreendo que os que gostam não a têm. Mas o meu sonho era: 'Não hei de morrer antes de adquirir uma gleba de terras para mim. Pretendo plantar muitos arvoredos. ${ }^{20}$

Seu padrinho "Dizia que o dinheiro mais bem-empregado era o dinheiro que se gasta comprando terras." ${ }^{21}$ Isso se transformou em uma máxima para ela. Lembrava sempre dos anos em que vivera com sua família em uma fazenda de Uberaba, como colonos. Num primeiro momento, quando teve de deixar a cidade, entristeceu-se porque a mudança significava abandonar a escola em que estava aprendendo suas primeiras letras, mas levou consigo seus livros e aos poucos foi se acostumando com a vida rural.

\footnotetext{
${ }^{18}$ Segundo Guy Debord, antes os homens reservavam o espaço da economia para sobreviver, agora era para existir. A existência antes estava reservada a outros setores. Sociedade do Espetáculo, op. cit., tese 40.

${ }^{19}$ Jesus, idem, p. 42.

${ }^{20}$ Jesus, idem, pp. 144-5.

${ }^{21}$ Jesus, idem, p. 19.
} 
Que vida gostosa! Eu ficava deslumbrada com a fartura. Verduras e frutas para mim aquilo tudo era a terra prometida ao Moisés que eu tive a ventura de encontrar. ${ }^{22}$

Ventura que teve efêmera duração, pois como sempre ocorreu em sua vida, teve que se mudar. Foram obrigados pelo fazendeiro a deixar o local, alguns anos após a chegada, quando a família já se sentia habituada aos afazeres do campo e compusera um círculo de solidariedade. Com a volta para a cidade, nunca mais Carolina ouviu o " - Quer mais?” de sua mãe, que tanto a fascinava. ${ }^{23}$

- Vão embora! Não os quero na minha fazenda. Vocês não me dão lucro. Só me dão prejuízos, a sua lavoura é fraca.

O meu padrasto pediu:

- Se o senhor me alugar o arado para arar as terras.

- Não dou nada, vão embora. (...)

Chorei com dó de deixar a nossa casinha, as verduras, os pés de jilóo. ${ }^{24}$

As perdas se sucederam no transcorrer de toda vida de Carolina, tendo que se mudar constantemente, de Sacramento para a cidade paulista de Franca, de Franca para Sacramento, da cidade para o campo e novamente para a cidade, de casa em casa. Obrigada a partir com o que o pouco que podia carregar, sofreu inúmeras vezes a experiência do deslocamento. Deixando para trás livros, pés de jiló, casa, roupas, criações, dinheiro por receber, utensílios, pessoas, amizades.

\footnotetext{
${ }^{22}$ Jesus, idem, p. 131.

${ }^{23}$ Jesus, idem, ibidem.

${ }^{24}$ Jesus, idem, pp. 135-6.
} 


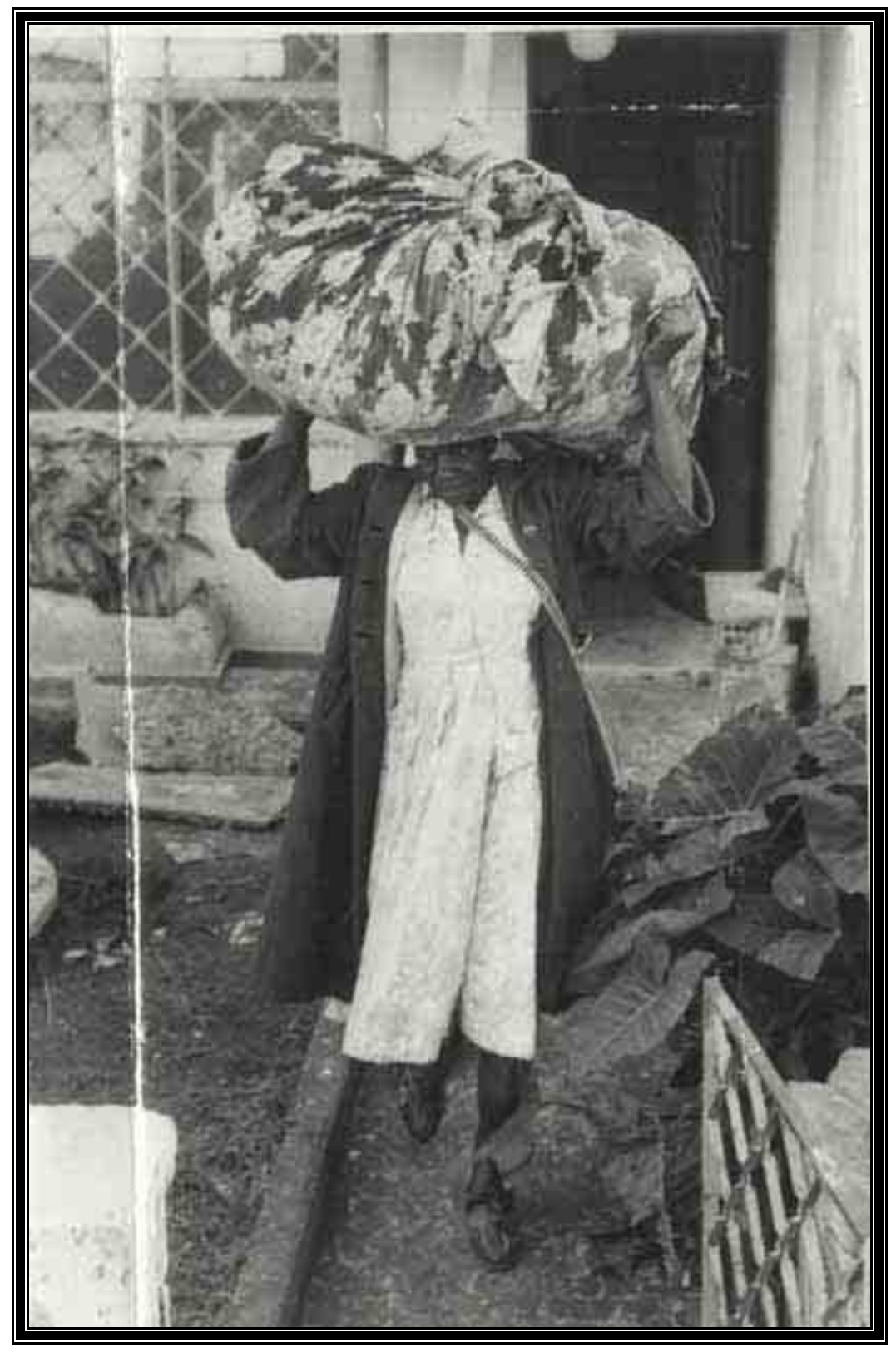

Imagem 4 - Carolina Maria de Jesus mudando-se da casa de alvenaria para o sítio, 1964. Jornal Última Hora, 28/01/1964. Foto: Sílvio / Arquivo do Estado de São Paulo. Arquivos EspeciaisIconográfico. Código: ICO-UH-0369-Carolina Maria de Jesus.

O negro foi desinteressando-se da vida de colono, fugia das fazendas levando apenas uma trouxa de roupas. Os seus pertences ficavam na fazenda. Voltava à cidade. la trabalhar em qualquer coisa e morava nos porões italianos, ou nos barracões. ${ }^{25}$

Essas constantes idas e vindas foram para ela, bem como para todos aqueles que passaram por experiências semelhantes, um aprendizado prático de relativismo, doloroso, mas reconfortante quando pensado como indício de

\footnotetext{
${ }^{25}$ Jesus, idem, p.50.
} 
liberdade. Apenas homens e mulheres livres poderiam circular de tal maneira, o que era de importância singular, apesar do sentimento de insegurança que acompanhava essa movimentação. Na dimensão mística, havia aprendido esse desprendimento com seu avô.

Ninguém é dono do mundo - dizia ele - O mundo é um hotel onde passamos uma temporada. Tudo que nos rodeia é pó. O ferro, com o tempo, transforma-se em pó. Um móvel também será pó. Tudo é terra no mundo. ${ }^{26}$

Com tantos deslocamentos, sentia-se dividida entre o querer viver no campo, em sua própria terra, com fartura, ou na cidade, onde poderia usufruir as "distrações" de que tanto gostava. As duas opções the pareciam interessantes e durante toda a sua vida hesitou entre uma ou outra. Quando estava na cidade, sonhava com a fartura do campo, quando estava no campo, sonhava com o entretenimento que poderia encontrar na cidade. A necessidade rondava os dois territórios, tornando seu sonho a cambaleante.

Eu já estava notando que o pobre vive mais com as pretensões. ${ }^{27}$ Compreendo que o sonho de pobre é sonhar, apenas sonhar. ${ }^{28}$

Relatou em suas memórias, publicadas postumamente, sua vida antes de migrar para São Paulo no início dos anos $40 .{ }^{29}$ Nessas evocações tem-se a seleção feita por Carolina do que ela considerava mais importante para explicar sua formação e o desenrolar de sua vida. Do dia-a-dia da pequena menina apaixonada pelas histórias de seu avô e pelas leituras do senhor Manoel às suas andanças por cidades do interior paulista e fazendas em busca de tratamento médico e trabalho, Carolina teceu em Diário de Bitita uma narrativa reveladora de sua intensa inquietação que a trouxe um dia a São Paulo, seguindo o ensinamento de sua mãe.

\footnotetext{
${ }^{26}$ Jesus, idem, p. 119.

${ }^{27}$ Jesus, idem, p. 62.

${ }^{28}$ Jesus, idem, p. 101.

${ }^{29}$ Diário de Bitita foi publicado primeiramente na França pela editora A. M. Metailié em 1982 com o título Journal de Bitita. Carolina havia entregado os originais para jornalistas franceses que a visitaram, pouco antes de sua morte que se deu em 1977, no sítio em que morava em Parelheiros.
} 
Minha mãe dizia que as exigências na vida nos obrigam a não escolher os pólos. Quem nasce no pólo norte, se puder viver melhor no pólo sul, então deve viajar para os locais onde a vida seja mais amena. ${ }^{30}$

Mas antes de decidir-se por esse caminho tinha um problema a resolver, onde ficava São Paulo? O senhor Manoel Nogueira havia Ihe explicado, quando ainda era uma criança, que o jornal lido em voz alta diariamente era impresso em São Paulo.

O tio Cirineu perguntou:

- Onde fica São Paulo?

O preto Fidêncio disse:

- É outro país. É só atravessar o Rio Grande você entra em Rifama, já está em São Paulo. ${ }^{31}$

Numa cultura em que o espaço estava pouco definido, o tempo também não seguia a marcação oficial. O que importava não eram os meses da folhinha, mas os festejos que se repetiam a cada ano. "O único mês que eu sabia que existia era o mês de maio. E os negros iam pedir esmolas. Saíam com uma bandeira com o retrato de São Benedito." A congada saía pelas ruas, pedindo esmolas para o santo e prometendo auxílios, até os ricos nele se amparavam. Era um reencontro com o passado, uma demonstração da coerência de todas as coisas e de sua permanência. ${ }^{32}$

E o zé-povinho ignorante dizia que o presidente Artur Bernardes tinha sido aluno de são Vicente de Paula e de santo Antônio de Pádua. O senhor Manoel Nogueira dava risada, porque era o único que conhecia história. E explicava que não era verdade. São Vicente de Paula era francês, e nasceu no ano de 1581 e morreu no ano de 1660. Mas o disse-disse já estava de boca em boca. E o presidente ficou sendo o aluno de são Vicente. ${ }^{33}$

\footnotetext{
${ }^{30}$ Jesus, Diário de Bitita, op. cit., p. 101.

${ }^{31}$ Tratava-se do jornal O Estado de São Paulo. Jesus, idem, p. 44.

${ }^{32}$ Jesus, idem, p. 22. Reginaldo Prandi explica, no primeiro capítulo de Segredos Guardados. Orixás na Alma Brasileira, op. cit., a concepção de tempo no pensamento tradicional africano.

33 Jesus, idem, pp. 44-5.
} 
Carolina não mais acreditava na contemporaneidade daqueles que viveram tão distantes no tempo e no espaço, nem na cartografia imaginária do negro Fidêncio, seu letramento a afastou irremediavelmente dessa dimensão encantada, entretanto o convívio com tais fontes de compreensão fazia com que acreditasse profundamente que em algum lugar, de alguma forma, algo especial estava reservado para si. Sentia a confusão do mundo, a mistura e, como o Riobaldo de Grande Sertão, buscava inserir-se num espaço em que tivesse o controle sobre o devir, preferindo as histórias inventadas "sem os erros e volteios da vida." 34 Suas visões e premunições eram uma forma de conseguir esse controle. Tinha avisos do que ocorreria e sentia-se a vontade com isso. ${ }^{35}$

Quando chegou a São Paulo no início da década de 40, seguindo a família para a qual trabalhava como empregada doméstica em Franca, Carolina sentiu a imperiosa urgência da escrita, atividade que acabou por tornar-se diária a partir da década de 50 , quando era moradora da favela do Canindé às margens do rio Tietê.

Sua personalidade fracionada entre a educação formal, o gesto espontâneo, os apelos da modernidade e os chamamentos do mundo dos encantados, a deixavam em uma posição privilegiada para decifrar as mudanças que estavam ocorrendo em si e ao seu redor em alta velocidade. $O$ domínio da escrita permitiu-lhe deixar o registro do que sentia, ao mesmo tempo em que Ihe possibilitava o ordenamento do mundo e uma retomada, ainda que em outra instância e de maneira diversa, do canto de seus ancestrais.

Onde estaria esse canto? De onde ele poderia ainda ser entoado?

Usei o barco por uma questão de lógica interna da história. Se os meus personagens, aqueles vagabundos, vivessem na beira da estrada, eles iriam para aquele mesmo lugar de caminhão. Eles foram de barco porque vivam na beira do rio. E aquele barco é um negócio bonito que não existe mais. Aquele barco ajudou a construir São Paulo. Ele trazia a areia da Vila Maria, daquelas várzeas todas. Os caras desciam o Tietê de madrugada e descarregavam a areia que era vendida para se fazer

\footnotetext{
${ }^{34}$ João Guimarães Rosa. Grande Sertão: Veredas, op. cit., p. 101.

${ }^{35}$ Um exemplo desses avisos foi quando Vera Eunice sua filha cortou o pé em 1958. Carolina escreveu em seu diário que havia sido avisada pela manhã, naquele mesmo dia, que isso ocorreria. Cf. Carolina Maria de Jesus. Meu Estranho Diário, op. cit., pp. 46-7. Costumava ter avisos sobre aborrecimentos, sobre quando devia sair de casa, a que horas devia retornar, etc.
} 
concreto. A cultura brasileira é uma merda mesmo, ninguém sabe de nada. Ficam pensando que eu botei o barco porque li Dante. ${ }^{36}$

Até hoje, pelos meandros caprichosos do Tietê, que se ligam pelos canais de rega e pelas calmas lagoas deixadas pelas enchentes, trafegam as barcaças carregadas até a borda, lentas e pesadas, à força de varejão, carregando materiais para os arranha-céus da cidade. ${ }^{37}$

O cineasta Ozualdo Ribeiro Candeias penetrou no labirinto, em busca de respostas. ${ }^{38}$ Nascido em 1922, na fazenda de seu pai que ficava na região Noroeste do estado de São Paulo, próxima à cidade de Ribeirão Preto, foi registrado em Cajubi, também em São Paulo. Filho de um imigrante português - Candeias se considera "meio mourisco e meio cigano" - não teve paradeiro em sua infância e juventude. Após uma temporada na capital, voltou com a família para o interior de São Paulo, Marília - "onde fui pela primeira vez ao cinema" - e depois Mato Grosso, São Paulo, novamente Mato Grosso. Serviu o exército e depois tentou a vida no Rio de Janeiro, em Recife, de novo no Rio de Janeiro e, finalmente, no final dos anos 40, outra vez em São Paulo, onde viveu em diversos bairros. A instabilidade econômica sempre acompanhou a família: "Moramos em casa muito bonita e moramos em cortiço." Seu pai teve várias ocupações e nas épocas "quando não tinha muito que fazer" era motorista de táxi, chegando a ter 3 carros. "No finalzinho de tudo ele abriu uma pensão muito grande para nordestinos, para comer e dormir, isso aqui em São Paulo."39

Candeias estudou nos grupos escolares da Penha e do Brás, mas teve que interromper os estudos, vindo a terminar o ginásio anos após. Depois de

\footnotetext{
${ }^{36}$ Ozualdo Candeias sobre seu filme $A$ Margem em entrevista a José Geraldo Couto. "Ozualdo Candeias termina O Vigilante", Folha de São Paulo, Ilustrada, 1/06/1993, apud Angela Aparecida Teles. Cinema e Cidade: Mobilidade, Oralidade e Precariedade no Cinema de Ozualdo Candeias (1967-92), tese de doutoramento apresentada ao Programa de Estudos Pós-Graduados em História da PUC-SP, 2006, p. 145. ${ }^{37}$ Mello Nóbrega. História de um Rio (O Tietê), São Paulo: Livraria Martins Editora, 1948. Em 1940 já havia muitos barcos, 2500, para pouco serviço, pois a areia do Tietê tornava-se escassa. Os tripulantes dessas embarcações, segundo Mello Nóbrega, eram principalmente velhos e crianças.

${ }^{38}$ Sobre o cineasta Ozualdo Candeias, a publicação mais importante é o catálogo da mostra Ozualdo $R$. Candeias, 80 Anos, organizada por Eugênio Puppo no Centro Cultural Banco do Brasil em 2002. Puppo fez uma série de entrevistas com Candeias, registradas em 25 horas de gravação. Alguns trechos dessas entrevistas foram publicados nesse catálogo. Alguns dos filmes de Candeias estão disponíveis em vídeo na Biblioteca da Escola de Comunicação e Artes da USP e na Cinemateca Brasileira. Cópias do filme $A$ Margem encontram-se no acervo da Fundação Padre Anchieta - TV Cultura e no Museu da Imagem e do Som de São Paulo. Nenhum de seus filmes, até o momento, estão disponíveis para compra em VHS ou DVD. Ele vive hoje num pequeno quitinete na Av. Rio Branco.

${ }^{39}$ Informações obtidas através do depoimento de Ozualdo Candeias concedido à Eugênio Puppo, trechos transcritos em Ozualdo R. Candeias, 80 Anos, op. cit..
} 
exercer várias atividades, tentou a carreira militar, e afirma ter sido expulso por mal comportamento. Tornou-se então, nos anos 50, funcionário público e caminhoneiro. Após comprar uma câmera para filmar discos voadores no interior de São Paulo, começou a estudar a técnica cinematográfica através de livros e assistindo a filmes que eram produzidos no Brasil. Por fim conseguiu um emprego de ator na Companhia Maristela no bairro do Jaçanã onde morava. ${ }^{40}$

Sua primeira imersão como cineasta foi com o curta-metragem Tambaú, Cidade dos Milagres, rodado em maio de 1955, por ocasião da última benção do padre milagreiro Donizetti Tavares de Lima que ocorreu no dia 30 daquele mês. ${ }^{41}$ Quando soube da notícia que o governador Jânio Quadros havia decretado o fim das bênçãos em Tambaú, interior de São Paulo, Candeias conversou com alguns colegas da região da Rua do Triunfo, pólo cinematográfico do período, e convidou-os para fazer uma reportagem sobre o assunto. $^{42}$

Peregrinos de outras cidades a Tambaú chegam todos os dias, conduzindo seus padroeiros. ${ }^{43}$

O documentário, sem som ambiente e com a voz em off do narrador, tendo ao fundo a trilha sonora composta por Villa Lobos e Bach, inicia-se com imagens de trens e caminhões lotados de peregrinos chegando à pequenina cidade. Candeias filmou as chaminés das dezenas de fábricas de cerâmica e, logo em seguida, a igreja, sobressaindo sobre a atividade industrial. Desde 1954, quando começaram as bênçãos do padre em praça pública, verdadeiras multidões acorriam à Tambaú, vindas de todos os recantos do país, congestionando estradas e amontoando-se na cidade. O imenso número de peregrinos que chegava em caminhões, trens ou automóveis ocupava todos os espaços. Os mais pobres hospedavam-se em pensões baratas ou alojavam-se

\footnotetext{
${ }^{40}$ Idem.

${ }^{41}$ O padre Donizetti, personalidade de extrema importância no contexto religioso dos anos 50 no Brasil, nasceu em Santa Rita do Passa Quatro, Minas Gerais, em 1882 e faleceu em 1961. Para uma biografia do padre, ver José Wagner Cabral de Azevedo. Padre Donizetti de Tambaú, Aparecida: Editora Santuário, 2001.

42 Ozualdo R. Candeias, 80 Anos, op. cit., p.17. Sobre a última benção do padre, cf. "Padre Donizetti: encerradas ontem as bênçãos em Tambaú", Folha da Noite, 31/05/1955.

${ }^{43}$ Curta- metragem: Tambaú, Cidade dos Milagres, pb, 14 min, 1955.
} 
como podiam nas praças e ruas, acendendo fogueiras para protegerem-se do frio, aguardando o momento de se aproximarem do padre considerado santo.

A atividade milagrosa do padre teria começado em 1929, três anos após sua chegada à cidade, mas a divulgação somente ocorreu a partir de 1954, ano do quarto centenário de São Paulo, principalmente após o destaque dado pela Revista Manchete de 11 de dezembro daquele ano, numa reportagem de Frederico Stern e Francisco Carvalho Henriques. Enquanto a capital comemorava seus arranha-céus e indústrias, Tambaú recebia os pedidos desesperados dos mais miseráveis e também de famílias ricas que chegavam em automóveis. Em um só dia, trezentas e cinqüenta mil pessoas chegaram para serem abençoadas pelo padre na cidade que tinha apenas nove mil e quinhentos habitantes. Em média, quarenta mil pessoas visitavam Tambaú diariamente. Formavam-se até vinte quilômetros de fila de caminhões transportando peregrinos nas estradas mais próximas. ${ }^{44}$

Eram cenas que começaram a causar incômodo para as autoridades tanto eclesiásticas quanto laicas, porque transferiam para uma localidade relativamente próxima da capital paulista - que se queria ver como moderna e atualizada com os grandes centros internacionais - manifestações que carregavam resquícios de um catolicismo popular que se desejava encerrado em um tempo remoto e em lugares distantes, mais ao norte do país. Foi um fenômeno explosivo, o que estava relativamente sob controle até aquele ano de 1954, extrapolou totalmente a margem de segurança. O próprio padre mostrava-se irritado com as exageradas demonstrações de admiração e carinho do povo que o cercava, o que fica evidente em algumas imagens gravadas por Candeias em que a multidão efusivamente procura saudar o "homem santo" que não conseguia sequer se movimentar no meio de tamanha aglomeração, sendo empurrado pelos que queriam tocá-lo e tentando desviarse com um certo nervosismo expresso pelos gestos e pelo olhar. Em 14 de maio de 1955, Padre Donizetti havia declarado na imprensa que condenava o fanatismo do povo. ${ }^{45}$ Esse incômodo com as entusiasmadas demonstrações de fé culminou com a determinação do governador Jânio Quadros proibindo as

\footnotetext{
${ }^{44}$ Os dados sobre número de fiéis e habitantes foram retirados do site da prefeitura municipal de Tambaú: www. tambau.sp.gov.br

${ }^{45}$ Recorte de artigo de jornal não identificado exposto em agosto de 2005 em espaço reservado à Secretaria de Turismo de Tambaú, próximo ao Santuário de Nossa Senhora Aparecida.
} 
bênçãos, o que foi aceito pela Igreja. O governador aproveitou-se do fato que a cidade não tinha estrutura para suportar tal afluxo de fiéis, pois não havia banheiros suficientes, comida, água, acomodações. Os fiéis, quando partiam, deixavam atrás de si uma cidade com aspecto de terra arrasada. Artigos da época denunciavam o consumo de água contaminada pelos peregrinos nos regatos próximos ao centro da cidade.

Peregrinos bebem as águas poluídas do riacho arrependido. Há perigo de graves epidemias, mas o governo estadual não toma as devidas providências. ${ }^{46}$

As pessoas no desespero de intensificar e preservar o sentimento que ali experimentavam, numa espécie de transe coletivo, procuravam levar para casa alguma lembrança do encontro redentor, arrancando a casca das árvores, pedras das ruas, telhas das casas, punhados de terra, enfim, tudo o que podiam carregar de Tambaú e que pudesse trazer em si a emanação da benção antes concedida. ${ }^{47}$ Os que dispunham de algum capital incentivavam o comércio de artigos religiosos comprando, no mercado instalado nas ruas, estatuetas, rosários, escapulários, garrafas com água benta em que procuravam a imagem de Nossa Senhora, livros de oração ou qualquer outro objeto que fizesse menção aos milagres de Donizetti. ${ }^{48}$

O filme de Candeias, mostrando esse intenso comércio local, os "romeiros ao desabrigo" nas noites frias, os pedintes, os doentes contrastava fortemente com a representação que se procurou muitas vezes estabelecer sobre o Brasil nesse período do pós Segunda Guerra: um país em desenvolvimento, voltado para o futuro, em plena atividade industrial e no compasso com os maiores centros culturais internacionais. Sua câmera

\footnotetext{
46 “A Verdade sobre Tambaú", Revista O Mundo Ilustrado, 1955, recorte em exposição de artigos e fotos na Secretaria de Turismo de Tambaú.

${ }^{47}$ Isso pode ser visto em imagens de época que são vendidos no formato VHS no Santuário de Nossa Senhora Aparecida em Tambaú.

${ }^{48}$ Tive a oportunidade em agosto de 2005 de fazer uma visita à Tambaú, com o intuito de conhecer de perto o fenômeno da peregrinação religiosa movida pela crença em Padre Donizetti. Pude perceber, decorridos 50 anos da última benção, a intensidade com que esse catolicismo popular ainda está presente, mesmo quando aparentemente controlado pela Igreja institucionalizada que ergueu no lugar da pequena igreja um templo de grandes proporções. As imagens do padre Donizetti que se vendem por toda a cidade, os inúmeros fiéis rezando em ladainha em torno do seu túmulo, a ânsia dos peregrinos por sentar na mesma poltrona em que ele descansava e tocar em seus objetos revelam uma permanência impressionante dos cultos de origem popular com toda a mescla característica de paganismo e rito cristão: rezar, tocar, beber, martirizar-se, evocar, repetir convulsivamente frases e gestos são imperativos para os fiéis de Tambaú.
} 
aproximou-se dos pobres em torno da fogueira, das mulheres com panos brancos na cabeça, fumando cigarros de palha, dormindo ao relento. Quando finalmente o enquadramento buscou o padre, o fez por detrás, focando a latinha coletora de ofertas e seus auxiliares no ritual. A benção foi filmada rapidamente, mostrando o sacerdote pronunciando palavras em uma sacada com o auxílio de um microfone e movimentando freneticamente uma das mãos. A seguir a câmera desloca-se para a multidão, que agitava panos brancos emocionada e tentava colher, com suas mãos, seus chapéus ou seus guardachuvas virados ao contrário, as pétalas de rosas despejadas do céu por aviões da FAB. Para encerrar o documentário, Candeias mostrou a sala dos milagres, com milhares de objetos deixados em sinal de fé.

O padre, que era aclamado de boca em boca e pela imprensa como curador, procurava ele mesmo fugir desse "arcaísmo milenarista". Numa série de fotografias expostas atualmente na cidade, Donizetti é retratado nas mais inusitadas situações, como, por exemplo, dirigindo seu carro esporte, fumando ou em poses muito semelhantes àquelas encontradas naquele período em fotos do presidente Juscelino Kubitschek, do milionário Nelson Rockfeller, ou dos artistas de Hollywood, demonstrando despojamento e modernidade. ${ }^{49}$

No início de seu apostolado, padre Donizetti foi pianista, tendo estudado no Conservatório Dramático de São Paulo, e regente de coral no Colégio São Bento. Na juventude havia cursado dois anos de Direito no Largo São Francisco, mas desistiu pela vocação sacerdotal. Quando ainda pároco em Vargem Grande do Sul, no início do século, costumava levar as crianças ao circo e também preparava espetáculos circenses. Sua biblioteca em Tambaú era composta principalmente por manuais de Psicologia de Massas, Métodos de Comunicação e Evangelização, entre eles O Orador do povo, de 1953; Como Fazer Amigos e Influenciar Pessoas de Dale Carnegie, Cia Ed. Nacional; de Lewis Munford. A Condução do Homem; de Manuel de Juge. Predication Populaire, 2 volumes; além de obras sobre a Revolução Francesa e textos literários como o Dom Quixote de Cervantes, Victor Hugo e Shakespeare.

\footnotetext{
${ }^{49}$ Essas fotografias estavam expostas em agosto de 2005 em espaço reservado à Secretaria de Turismo de Tambaú, próximo ao Santuário de Nossa Senhora Aparecida. A Revista Manchete de 27/12/1958, nº 349, traz uma série de fotografias do futuro presidente João Goulart com o mesmo estilo de poses: cigarro entre os dedos, pernas trançadas, quadril deslocado, polegar no cinto, o que demonstra como esse era o estilo do momento.
} 
Getúlio Vargas também tinha lugar em suas estantes com A Nova Política do Brasil, o que também ocorria com Catulo da Paixão Cearense com o livro Um Boêmio no Céu. ${ }^{50}$

Jorge Americano, professor da mesma Faculdade em que o padre estudara, em suas memórias, publicadas em 1963, deixou um relato de suas impressões sobre o que ocorria em Tambaú.

Viúvas vendiam pastéis e confeiteiros arrumavam barracas de bolos e doces, afastando as moscas. Quitandeiros apregoavam amendoins, nacos de melancia e laranjas descascadas. Abriam-se pensões para receber os crentes.

Enchia-se de rumores o Templo até então silencioso.

Ao redor da cidade loteavam-se terrenos.

(...)

Mendigos estendiam os chapéus à caridade pública, vendedores de santinhos asseveravam a miraculosidade das relíquias e batedores de carteira colocavam distraidamente as mãos nos bolsos alheios, enquanto a polícia orientava o tráfego nas ruas entulhadas.

(- 'Mas tudo isto é plágio!' - 'É plágio, mas é verdade.').

Tempos depois correu a notícia de que o padre entrara em gozo de licença, e Tambaú voltou à quietude primitiva. ${ }^{51}$

Ao mesmo tempo em que esse comércio desenfreado e principalmente informal tomava pulso na cidade, as fábricas de cerâmica eram obrigadas a parar suas atividades nos dias de maior fluxo de fiéis, devido à falta de estrutura para o funcionamento. O tempo da fábrica estancava compulsoriamente. Houve uma tentativa frustrada da deputada estadual Conceição Costa Neves, em 1955, de transferir as bênçãos do padre Donizetti para a cidade de São Paulo, desafogando assim a região de Tambaú. Já que o fenômeno era inevitável, pensou-se em um aproveitamento do prestígio do pároco. Ela apresentou a proposta junto a Assembléia Legislativa que decidiu mandar uma comissão de deputados para verificar o assunto em Tambaú. O próprio padre Donizetti, entretanto, disse que se negaria a receber os deputados porque não desejava ser transferido, o que deve. O que se pode perceber nesse episódio é que, ao mesmo tempo em que o padre incomodava pelo transtorno de colocar em evidência as mazelas que se preferia esconder e

\footnotetext{
${ }^{50}$ A biblioteca do Padre Donizetti está preservada na casa paroquial na cidade de Tambaú, onde pude recolher o título dos livros.

51 "Os milagres de Tambaú", Oscar Americano. São Paulo Atual, 1935-1962, São Paulo: Melhoramentos, 1963, p. 325.
} 
tumultuava o desenvolvimento das atividades industriais, aproximar-se dele era garantir ampla consideração pública e eleitoral. ${ }^{52}$

Diante de tais interesses políticos, institucionais e econômicos, poderia ser Tambaú o canto dos encantados? Seria de lá que se poderia entoar o canto? Anos após, em 1967, Candeias propôs um novo ponto de encantamento.

O cineasta parecia, particularmente, ter uma preferência pela temática da escassez, do desejo desesperado, da procura de um alívio para os trabalhos do mundo, do movimento incessante, da crença na suspensão do tempo. Isso se manifesta, também, no seu primeiro longa metragem A Margem. Considerado por muitos críticos, mas não pelo próprio Candeias, como precursor do cinema marginal, tendo dado nome ao movimento, esse filme inicia-se com a cena do interior de uma canoa projetada na posição vertical, dando a impressão de se tratar de um arranha-céu. ${ }^{53}$ Essa embarcação desce o Rio Tietê, sem que se possa ver quem a conduz. Na margem, cheia de entulho, lixo, ruínas e favelas, desenrola-se o enredo repleto de sensualidade. Os quatro personagens principais, dois homens e duas mulheres vêm a barca que passa por debaixo de uma ponte. Quando a canoa surge do outro lado, uma mulher está sobre ela que desliza suavemente, sem remo, até a margem. $\mathrm{Na}$ cena seguinte, a misteriosa mulher aparece encostada no parapeito da ponte. Todos atravessam a ponte e olham para aquela criatura singular, num momento de perplexidade. Quando retornam, jogadores de futebol de várzea cruzam a ponte, carregando sua taça.

O filme segue com os personagens que andam para lá e para cá, volteando, desviando, errando, enquanto o rio corre carregado de dejetos. ${ }^{54}$ Apesar do cenário de desolação, as pessoas se comportam como se estivessem em uma estância balneária, gingando, passeando, sem compromisso tendo ao fundo uma trilha sonora eclética: batuques, bossa nova,

\footnotetext{
52 "Padre Donizetti: encerradas ontem as bênçãos em Tambaú", op. cit..

${ }^{53}$ Cinema Marginal é a denominação dada aos filmes produzidos por um grupo de jovens cineastas paulistas a partir do final da década de 60. Eles freqüentavam o pólo cinematográfico da Rua do Triumfo e lá tomaram contato com Ozualdo Candeias. Eugênio Puppo e Vera Haddad. Cinema Marginal e suas Fronteiras. Filmes produzidos nas décadas de 60 e 70, São Paulo: Centro Cultural Banco do Brasil, 2001. ${ }^{54}$ Em 1948, Mello Nóbrega escreveu que a água do Tietê era poluída "pelos esgotos da cidade e pelos despejos das indústrias que fumegam às suas margens.” Op. cit., p. 75.
} 
toques de viola, iê-iê-iê. ${ }^{55}$ São poucos os diálogos e sempre entremeados por expressões imperativas de desejo: "Me dá!", "Dá o meu!" e questionamentos de expectativa e interesse "O que é que você trouxe para mim?". O desejo nunca é plenamente satisfeito, a expectativa jamais é inteiramente atendida entre esses personagens despejados. Mas eles aguardam. ${ }^{56}$

Como pareciam aguardar os homens e mulheres, migrantes à beira de uma via expressa, provavelmente a Avenida Marginal, captados pela câmera de Candeias, com suas roupas simples, suas trouxas com seus poucos pertences, chapéus e olhar ansioso. Não se sabe no filme de onde vieram ou o que fazem ali, parecem esperar algo. Eles possuem a maçã que a mulher pede e obtêm. As prostitutas das margens, os caminhoneiros que param, os capoeiristas, as crianças brincando, as obras em andamento, o lixão, os urubus, as vacas pastando, a dança, a flor, elementos que se sobrepõem e interagem, para indicar a simultaneidade dos acontecimentos e a possibilidade do singelo e profundo adquirir força diante da escassez. O cinema, com suas técnicas de descolamento e remontagem, mostrava-se como um meio eficaz para a expressão desse transcorrer controlado, em que tudo acontece ao mesmo tempo e tudo parece ser sempre o mesmo. O roteiro de $A$ Margem foi marcado pelo improviso e pelo aproveitamento dos detalhes e surpresas que cruzavam o caminho. Candeias sempre foi um cineasta de externas, do espaço livre e aberto, mantendo as características reais de iluminação, articulando o acaso e as condições nem sempre apropriadas para a filmagem, com um poderoso e quase obsessivo senso de organização e perfeccionismo estético. "Quase todo diretor faz tudo que está no roteiro, mas eu não faço nada ou posso até fazer.". ${ }^{57}$

O personagem dono da flor, guardada como um bem precioso, num momento de puro lirismo, cai de joelhos e de mãos postas começa a sorrir, a cena seguinte é de uma igreja abandonada em ruínas, paredes mofadas, teto destruído, da qual surge um beato descalço, recitando a Ave Maria em latim e abençoando os que dele se aproximavam. Seu ritual é marcado pelo toque do

\footnotetext{
${ }^{55}$ A trilha sonora do filme é de Luiz Chaves, executada pelo Zimbo Trio.

${ }^{56}$ A Margem. São Paulo, 1967, 35 mm, pb, 96 min. José Carlos Avellar chamou o cinema de Candeias de silencioso, eu diria que se trata de um cinema gestual, um cinema da exuberância, muito mais do que da palavra. Sobre esse assunto ver capítulo 3. Cf. "Três notas sobre o que está no centro da margem" in Ozualdo R. Candeias, 80 Anos, op. cit., p.36.

${ }^{57}$ Ozualdo R. Candeias, 80 Anos, op. cit., p. 28.
} 
sino, mas é um sino incomum, um sino de lata, feito de restos, que emite sons de lata, estridentes, aos quais se sobrepõem aos poucos os sons de sinos verdadeiros. O enlace religioso do filme vai se formando com a aparição do homem santo e cresce de intensidade com a aproximação do cortejo de casamento e dos festeiros do Divino Espírito Santo.

A bandeira do Divino, carregada por um negro é respeitosamente beijada por aquele personagem que, aos poucos, assume uma importância central no enredo, um ser desprovido da razão, um ser que é só sentimento, um ser que caminha com sua flor. A religiosidade está mais forte nele, a ligação com o mundo é nele mais presente, ele se agita diante da desolação. Esse homem-sentimento é referenciado pelos festeiros que seguem em procissão acompanhados por tambores e um mascarado, caminhando em direção a um um subúrbio de fachadas coloniais e casas de pau-a-pique, provavelmente no nascedouro do rio.

Quando Candeias aborda o aspecto religioso em seus filmes, não se trata de uma religião oficial e hierárquica, pois essa nunca o interessou. Desde a época das filmagens de Tambaú, ele procurou desviar-se do parâmetro institucional e verter seu olhar sobre o assombroso e exuberante universo da religiosidade popular. O padre santo é desfocado para que se vislumbre a multidão. Numa verdadeira prática de détournement, Candeias em A Margem, aproveitou-se da temática e dos pontos constituintes de um discurso imposto e tentou compreender o que nele estava invisível, o que fugia dele e se escondia por detrás da aparente submissão. 


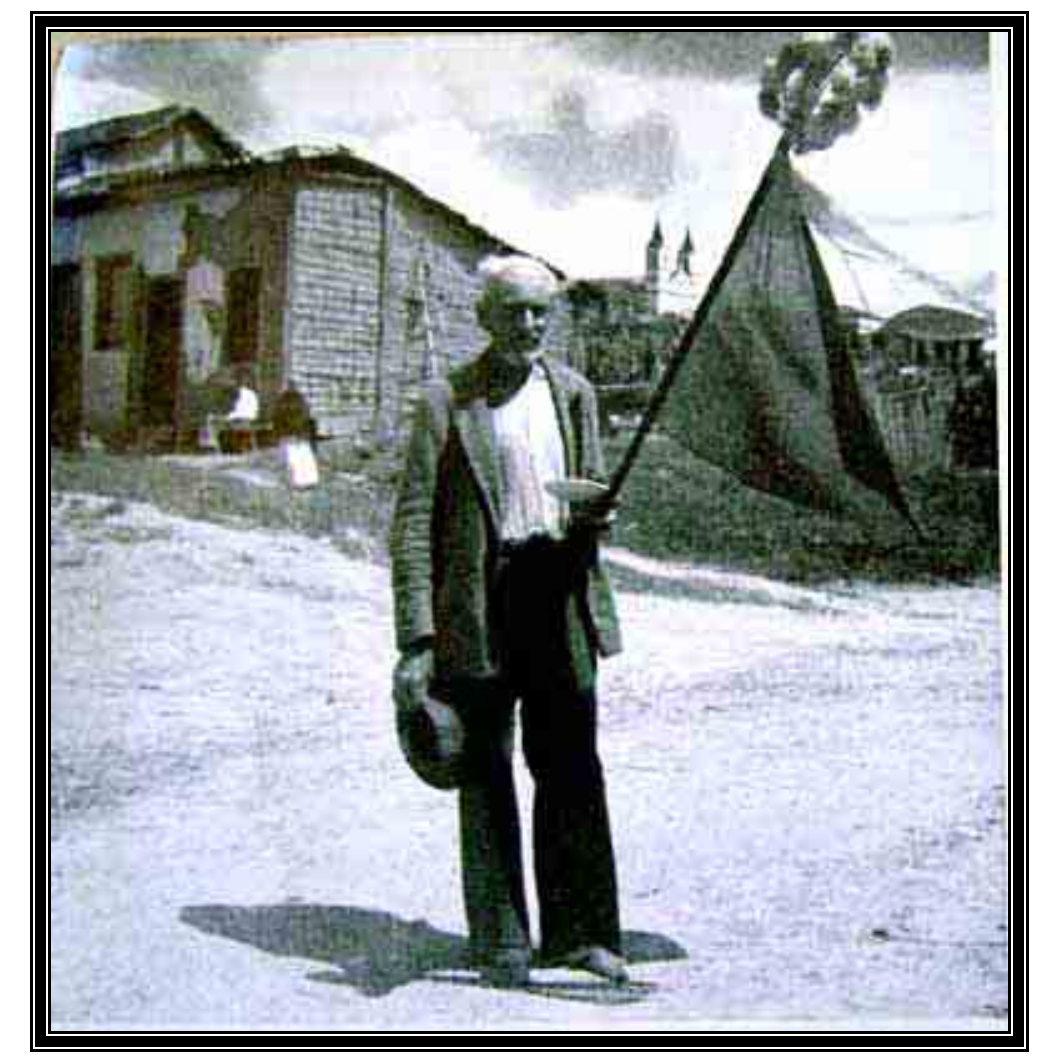

Imagem 5 - "Um São Paulo que pouca gente conhece". A Bandeira do Divino em Salesópolis, onde nasce o Rio Tietê, 1940. Paulistania, nº 7, maio / junho de 1940, p. 22.

A Margem foi o seguinte: eu inventei a porra da história a partir de umas coisas que eu tinha lido num jornal - que eu leio jornais -, daí eu cato essas coisas e enfio na história. Eu vi a notícia de uma mulher que estava esperando o noivo pra casar, ele não apareceu, ela nunca mais tirou o vestido e saiu por aí afora. O resto eu inventei, mesmo. O que me motivou foi essa mulher do véu, que ela não tirou mais. O resto do filme é que eu andava lá pela beirada do Tietê, morei ali pelo Canindé, morei lá pela Vila Maria, Vila Guilherme. O que é importante é como eu invento as besteiras, a gente tropeça com elas por aí, né? ${ }^{58}$

As coisas que catou do jornal e as besteiras com as quais tropeçou no cotidiano, possibilitaram a Candeias a composição de um espaço encantado.

\footnotetext{
${ }^{58}$ Ozualdo R. Candeias, 80 Anos, op. cit., p. 20.
} 


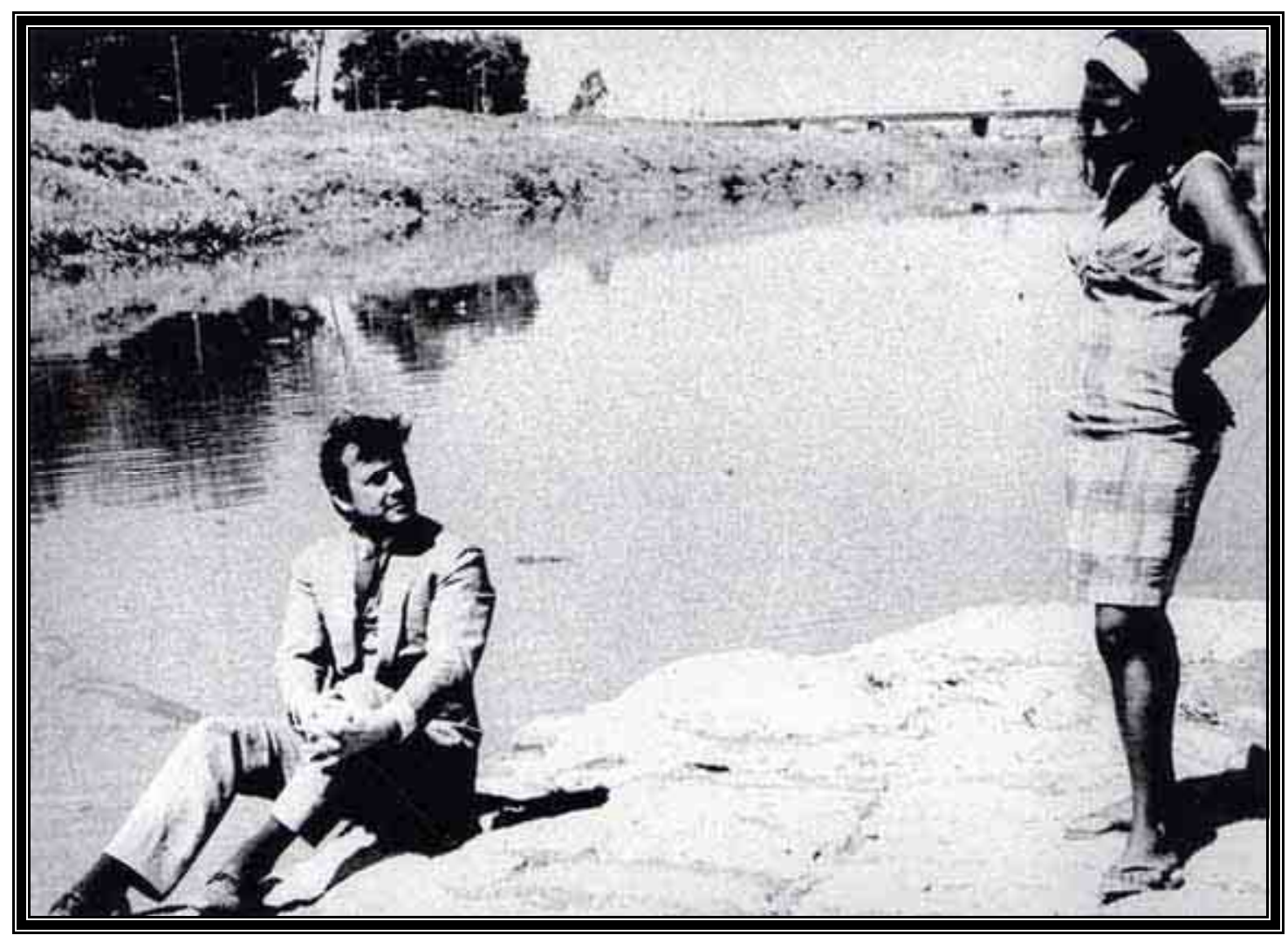

Imagem 6 - Cena do filme $A$ Margem de Ozualdo Candeias, 1967. Fotografia publicada em Eugênio Puppo e Vera Haddad. Cinema Marginal e suas Fronteiras. Filmes produzidos nas décadas de 60 e 70, São Paulo: Centro Cultural Banco do Brasil, 2001.

Após a aparição do barco misterioso, tem-se a cena acima em que a mulher requebrando os quadris, com chinelo e vestido colado ao corpo, se aproxima do homem de terno que está sentado à beira do rio e diante de sua aparente indiferença lhe pergunta: "Como é o cara, não estou agradando não?" Sem dar tempo para a resposta, ela o empurra com o pé para dentro das águas, dá uma gargalhada e se atira logo a seguir, dando a ele a oportunidade de se unir aquele mundo de espera, numa espécie de batismo primordial.

A margem do rio e a várzea são concebidas nesse filme como o espaço de encantamento das populações moventes, onde somente o tempo presente se manifesta, não diferindo do passado. Não há flashback, as explicações são negadas, não há causa ou efeito, o filme não se constitui como uma história que se desenrola numa seqüência linear. Contudo há uma tensão no horizonte que insiste em atrapalhar o encanto, ela vem da cidade que surge do alto da colina. É lá que alguns dos personagens ganham a vida, se tornam massa, virando-se, vivendo de pequenos biscates: vendendo café nos escritórios, 
pedindo esmolas, prostituindo-se. ${ }^{59}$ É na cidade que são punidos quando infringem as leis, é nela que seu corpo é violado. O tempo aí ressurge como uma força avassaladora, o ritmo é intenso, a multidão invade a cena. Só na margem e na várzea, onde estas ainda não foram tomadas pelo trânsito convulsivo das avenidas marginais, é possível andar vagarosamente, hesitando pelo espaço vazio ou de parcas habitações, não pensando na sobrevivência, sonhando com uma vida encantada. Pode-se até correr ou flutuar no amplo espaço não urbanizado.

Apesar do título do filme indicar a margem como ponto central, a várzea, como território expandido, fica aberta à deambulação dos personagens. Muitos aparecem e desaparecem, sem deixar sinal. Eles não se limitam à beirada do rio, invadem a zona intermediária e depois alcançam a colina, percorrem portanto todos os pontos da cidade, mas a maior parte do tempo permanecem na várzea.

Por que na várzea?

(...) entre 1890 e 1940 o relacionamento entre os moradores de São Paulo e o Tietê foi intenso, complexo e abrangente, tanto pelo rio acolher uma infinidade de práticas que compreendiam diferentes dimensões da vida social, como por fornecer recursos naturais imprescindíveis ao processo de urbanização paulistano. ${ }^{60}$

A instalação humana ali foi um processo bastante difícil e particularmente dramático. E isso dividiu um pouco a história da cidade entre os que estão na área de cima, nas áreas secas da cidade e aqueles que ficam nas áreas baixas, nas áreas úmidas e, portanto, nas áreas insalubres da cidade. Essa população das áreas insalubres é a população das várzeas, e a expressão "varzeano" qualifica o tipo de pessoa que no contexto da cidade de São Paulo é tido como a menos civilizada, a mais rude, a mais rústica, aquela especialmente destinada ao trabalho pesado. ${ }^{61}$

Esse lugar central ocupado pelo rio, suas margens e a várzea na vida das camadas pobres de São Paulo de fins do século XIX até meados do século XX é o que pode explicar a escolha por esse espaço e não outro pelo cineasta.

\footnotetext{
${ }^{59}$ Segundo Jorge Americano, as vendedoras de café em garrafas térmicas surgiram em São Paulo por volta de 1959, por "iniciativa de alguma pobre." O negócio prosperou e se espalhou. Apareciam nos pontos de táxis, nas construções, "nas aglomerações de operários que esburacam a cidade", com aventais azuis sobre os vestidos pobres. Op. cit., p. 171.

${ }^{60}$ Janes Jorge. O Rio que a Cidade Perdeu. O Tietê e os Moradores de São Paulo, 1890-1940, tese de doutoramento, FFLCH-USP, 2004, pp.9-10.

${ }^{61}$ Nicolau Sevcenko. "Periferia no Centro". Catálogo da Exposição Brasmitte - Intervenções Urbanas: Grupo de Intervenção Urbana, 1997, pp.61-2.
} 
Ele escolheu o vale profundo para situar a encantaria que havia catado em seus deslocamentos culturais. Ele mesmo foi um morador das bordas, um freqüentador das margens. ${ }^{62}$ Nelas depositava grande parte de sua afetividade. Atravessava incansavelmente o rio, como seus personagens, de cá para lá, de lá para cá, por isso os elementos culturais que colocou no filme trazia-os consigo de maneira espontânea, numa caça que não foi feita em um dia, nem tampouco nos cursos de cinema que freqüentou no MASP ou nos livros que leu, mas que foi arduamente elaborada antes disso, durante toda uma infância de menino viageiro, de todo um percurso de jovem mal comportado e questionador: "sempre gostei de vagabundagem, bebia, andava por aí, classe média nunca..."63 Aprendeu a cruzar a ponte, carregando o que podia, voltando com o que conseguiu, levando o que transformou e afinando assim sua sensibilidade.

Por terem se constituído como terrenos mais baratos, devido à insalubridade e aos alagamentos periódicos, as várzeas atraíram aqueles que não tinham condições de habitar as regiões mais valorizadas, sendo sistematicamente despejados devido à sua situação econômica e cultural. Eram os imigrantes, os egressos da escravidão, os mestiços. ${ }^{64}$ Essas regiões alagadiças, historicamente, ofereciam para essas populações possibilidades de entretenimento, sobrevivência e fuga. Estando na várzea era possível nadar e banhar-se no rio, jogar futebol, esconder-se no mato, lavar roupas, pescar em

\footnotetext{
62 "Aos pobres, fossem imigrantes recém-chegados, brancos pobres ou negros expulsos do centro pelo aburguesamento progressivo, sobraram as bordas e as partes baixas da cidade, em geral as terras baixas enxutas lindeiras a rios e córregos, mas cuja ocupação avançava rumo as várzeas, mas de qualquer modo sujeitas, a terríveis problemas de drenagem, (...).” Janes Jorge, idem, p.34. Candeias praticou esporte nas margens do Tietê. Quando estudava à noite, nos anos 30, costumava remar no rio.Teve oportunidade, portanto de acompanhar todas as transformações do Tietê. "Em 1967, quando fez seu primeiro longametragem, já estava preocupado em denunciar a degradação daquele espaço muito significativo na sua vida e na de outros moradores da cidade."Angela Aparecida Teles. Cinema e Cidade, op. cit., p. 145.

${ }^{63}$ Ozualdo R. Candeias, 80 Anos, op. cit., p. 29. No mesmo livro está a opinião de Jean-Claude Bernardet para quem o talento de Candeias quando filmava "ele tirava de si próprio e não de uma formação cinematográfica (...)", p. 33. Segundo Nicolau Sevcenko, "é por meio desses nós ásperos, travados nas profundezas da memória individual, que se atualizam e transmitem as tradições, atribuindo sentidos e dando formas à vida coletiva." "Introdução" in Nicolau Sevcenko (org.) História da Vida Privada no Brasil, vol 3, São Paulo: Companhia das Letras, 1998, p. 46.

${ }^{64}$ Alguns trabalhos que trataram das várzeas dão mais importância ao fato delas serem em São Paulo na década de 1920 ocupadas pelos clubes à beira-rio, com competições de remo e natação. Esse é o caso do estudo de Iraúna Bonilha. O Desenho da Paisagem à beira-rio e as Metamorfoses da Várzea do Tietê na Cidade de São Paulo, dissertação de mestrado, FAU-USP, 2000. É assim que elas são lembradas hoje pelos meios de comunicação em geral, esquecendo-se de que esse era o uso mais restrito da várzea, destinado a poucos. A maioria da população paulistana tinha com a várzea uma relação muito mais intensa, próxima e menos organizada, sendo ela um espaço de sobrevivência, entretenimento e moradia para aqueles que jamais tiveram acesso a esses clubes.
} 
alguns trechos, manter criações, morar. ${ }^{65}$ Nos anos 50 e 60 , a retificação do Tietê chegou ao seu termo e a várzea foi sendo paulatinamente sepultada pela construção das avenidas, restando apenas margens estreitas. ${ }^{66} \mathrm{~A}$ população antes residente nessas margens foi irremediavelmente lançada para a periferia da cidade. Foi nesse instante crítico que Candeias filmou, foi no momento de maior perigo que ele entoou seu canto. ${ }^{67}$

Nesse sentido, em A Margem o rio transformou-se não no espaço da construção, mas da derrocada da cidade moderna e modernizada, ela é o contraponto da urbanização desmedida. O cineasta se fixou muito mais nos volteios do Tietê que estavam em sua memória, do que na sua linearidade artificiosa gerada pelas obras de retificação e desocupação das margens. Era um rio que mudava constantemente de leito, modelando seu solo arenoso ao sabor das cheias. ${ }^{68} \mathrm{O}$ rio voltava, no filme a adquirir seu papel de trocas $e$ invenções, mas agora só no plano da poesia. ${ }^{69}$ Se de suas margens foi retirada a areia e o cascalho que possibilitou a construção de São Paulo, se nelas foram feitos os tijolos, se o rio foi transformado num canteiro de obras quase eterno, se nele depositaram-se os resíduos urbanos, foi também a partir dele que Candeias encontrou seu canto, invertendo o sentido de sua importância. ${ }^{70}$

A história do Tietê tradicionalmente o inseriu na irreversibilidade das transformações da cidade, reservando-lhe o lugar reconhecido como estrada movente, por onde passavam as monções, admitindo sua importância central na constituição urbana e na formação do território brasileiro. ${ }^{71}$ Para Candeias, o

\footnotetext{
${ }^{65}$ Sobre o processo de expulsão das populações pobres da região central da cidade devido à especulação imobiliária e aos projetos de reurbanização, cf. Paulo César Garcez Marins. "Habitação e Vizinhança: limites da privacidade no surgimento das metrópoles brasileiras" in Nicolau Sevcenko (org.) História da Vida Privada no Brasil, vol 3, São Paulo: Companhia das Letras, 1998, pp. 131-214. Sobre o Tietê como rio coiteiro, que desde tempos coloniais servia de esconderijo para escravos fugidos e homens livres perseguidos, cf. Mello Nóbrega, op. cit., p. 132.

${ }^{66}$ A canalização do Rio foi concluída durante a prefeitura de Prestes Maia, entre 1961 e 1965.

${ }^{67} \mathrm{O}$ Tietê "Despiu-se de todo encanto e de todo mistério; despoetizou-se e empobreceu (...)." Mello Nóbrega, op. cit., p. 183. Justamente em 1967 foi elaborado o Plano de Aproveitamento Urbano do Vale do Tietê. Cf. Iraúna Bonilha, O Desenho da Paisagem, op. cit., p. 241.

${ }^{68}$ Iraúna Bonilha, idem., p. 43.

${ }^{69}$ Janes Jorge, O Rio que a Cidade Perdeu, op. cit., p. 70.

${ }^{70}$ Segundo Janes Jorge, "Não é exagero afirmar que o Tietê é o mais longo canteiro de obras de São Paulo, no tempo e no espaço, (...)". Idem, p. 7. Segundo o ex-campeão de natação Victório Filellini a Nitroquímica, situada em São Miguel, no início dos anos 40 despejou um tambor cheio de ácido no Tietê, causando um desastre ecológico de imensas proporções.Apud Iraúna Bonilha, O Desenho da Paisagem, op. cit., p. 231.

${ }^{71}$ São muitos os trabalhos que salientaram a importância histórica do Rio Tietê, o principal deles é sem dúvida Monções de Sérgio Buarque de Holanda que foge da visão triunfal narrando com volteios a história dos paulistas que desciam o rio. Monçães, $3^{\text {a }}$ ed., São Paulo: Brasiliense, 1990. Pode-se aqui
} 
Tietê deixa de ser o vetor do progresso de São Paulo, do desbravamento de territórios, da pertinácia dos paulistas propalada insistentemente pelo discurso oficial, para ocupar o papel de vale das borboletas, ou seja, de território mágico onde a confusão do mundo deixa de existir, onde o tempo fica em suspensão. ${ }^{72}$ Candeias sugere uma reinterpretação da história pelo aproveitamento de elementos de cultura muitas vezes ignorados, mas que estão contidos nos relatos sobre o rio e sobre a cidade. A busca pelo Eldorado distante, empreendida pelos que nos séculos XVII e XVIII tudo abandonavam para seguir o curso do rio em direção ao sertão, volta em $A$ Margem. ${ }^{73}$

Isso se evidencia na presença da mulher na canoa. Ela passa ao largo, observando a vida dos personagens e num determinado momento convidandoos, sem qualquer palavra ou gesto, para um passeio eterno. Não se trata de uma referência direta à morte e à barca de Caronte, como foi muitas vezes interpretado pelos estudiosos de sua filmografia e veementemente negado por Candeias. $^{74} \mathrm{O}$ filme não trás a morte como salvação final dos seres desterrados porque isso seria admitir a irreversibilidade do tempo e a conclusão da história. No mundo encantado não há redenção. ${ }^{75} \mathrm{O}$ que os quatro personagens encontram um após o outro, é o que procuravam, o contato direto e atemporal com uma entidade encantada, que agora está visível, em pé sobre a canoa. Desde muito tempo acreditava-se que no Tietê

destacar também o livro clássico de Mello Nóbrega. História de um Rio (O Tietê), op. cit.. E trabalhos recentes, ainda não publicados, como o de Janes Jorge, idem.

${ }^{72}$ No tempo remoto das monções que partiam em direção ao Mato Grosso em busca de riquezas e escravos, propagaram-se histórias mágicas sobre o rio Tietê e seus afluentes. Fantasmas aterrorizavam “os proeiros, pilotos e calafates nos remansos e estirões (...).”Mello Nóbrega, op. cit., p. 40. Inácio Araújo ao escrever sobre $A$ Margem percebeu a maneira especial que Candeias dispôs os personagens em cena, fazendo "com que eles como que flutuem na tela, como se o filme se referisse ao mesmo tempo a esse mundo real, da margem, e a um outro, imaginário, e como se os personagens pudessem habitar os dois ao mesmo tempo: o que lhes era reservado pelo mundo e aquele que criavam, e no qual efetivamente sobreviviam." In Eugênio Puppo e Vera Haddad, op. cit..

${ }^{73}$ Sobre a busca da "terra livre e distante onde ainda não chegava a opressão dos bandos e cartas régias (...).”, ver Mello Nóbrega, op. cit., p. 70. Sobre a importância do mito do Eldorado no Brasil colonial, cf. Sérgio Buarque de Holanda. Visão do Paraíso: os Motivos Edênicos no Descobrimento e Colonização do Brasil, $4^{a}$ ed., São Paulo: Companhia Editora Nacional , 1985.

74 Arthur Autran afirma que no filme de Candeias " $A$ paz só vem com a morte, permitindo aos personagens o fim dessa deambulação das consciências (...)." “A Margem” in Ozualdo R. Candeias, 80 Anos, op. cit., p. 52. Teles, em tese recentemente defendida, compartilha dessa interpretação, op. cit., p. 137.

${ }^{75}$ Segundo a tradição iorubá, as punições e as benesses que possam ser merecidas não se aplicam ao ser individual, mas à toda coletividade. "Trata-se de uma concepção ética focada na coletividade e não no indivíduo, não existindo a noção ocidental cristã de salvação no outro mundo nem a de pecado." Reginaldo Prandi. Segredos Guardados, op. cit., p.35. Assim também pode ser entendida a tradição que envolve $A$ Margem de Candeias. 
além das iaras com seus longos cabelos negros, existiam esses seres "a descer e subir o rio em embarcações misteriosas, sem remo nem zinga(...)." 76 Ela vem das águas, ela garantirá sua permanência no fluxo, sem tocar as margens. Quem os espreita desde o início, portanto é um ser perigoso, na forma de uma mulher misteriosa e sensual, mas o único capaz de garantir a preservação do tempo e a volta do passado como presente. $O$ rio enfeitiçado da crendice popular, que corre ao revês, do oceano para as terras internas, ressurge em $A$ Margem com toda a força e é nessa direção que os personagens se deixam levar. ${ }^{77} \mathrm{Da}$ barca o canto pôde finalmente ser entoado.

Talvez também o pudesse ser do Morro da Geada, onde viveu seus primeiros anos o menino João Antônio, na divisa entre São Paulo e Osasco, com seu pessoal amulatado, mameluco, tangido do Rio de Janeiro pela fome de $1929 .^{78}$

Desde cedo, aprendi a subir ladeira e a pegar bonde andando. Posso dizer, com humildade orgulhosa, que tive morros e bondes no meu tempo de menino. Eu conheci, lá longe, o sol de montanha no Morro da Geada, lá pelos lados do Jaguaré, de onde se avistava, mais à direita, um ponto meio preto, quase azulado, tão vistoso - o pico do Jaraguá. Ah, tempos...o Rio Tietê, como o Pinheiros, dava peixe, a gente atravessava os dois de balsa ou de bote, uns caíques que enchiam o coração das velhas de medo e o deste aqui de um tropel. A gente não dizia: o rio, os rios; todos diziam: o Tietê, o Pinheiros. Eles eram tão da gente. $^{79}$

\footnotetext{
${ }^{76}$ Mello Nóbrega, op. cit., p. 130.

77 Segundo Mello Nóbrega, Taunay imaginava os primeiros moradores de São Paulo "a cismar nos arcanos do rio enfeitiçado, cujas águas vinham inexplicavelmente das bandas do oceano (...)."História de um Rio, op. cit., p. 45. Mario de Andrade também refletiu sobre essa peculiaridade do rio em "Meditação sobre o Rio Tietê", poema de 1944-5. Para ele, segundo Nicolau Sevcenko, "O Tietê aparece assim convertido num rio escravo, dominado e brutalizado, emblema fluido do povo oprimido vivendo às suas margens e tratado pelos potentados como uma massa amorfa, empurrada à força numa longa coluna errante de malsinados." Cf. Nicolau Sevcenko. "Dérive poética e objeção cultural: da boemia parisiense a Mário de Andrade." Literatura e Sociedade. Departamento de Teoria Literária e Literatura Comparada, FFLCH-USP, São Paulo, número 7, pp. 16-34, 2003-2004.

${ }^{78} \mathrm{O}$ arquivo João Antônio, com o acervo deixado pelo escritor, encontra-se na UNESP de Assis desde 1998. No Departamento de Literatura daquela universidade estão sendo desenvolvidas várias pesquisas a partir desse acervo. Entre elas podem-se citar os mestrados que foram concluídos até 2005, quando lá estive pesquisando. Cleide Durante Assis de Jesus. A crítica de João Antonio na "Tribuna da Imprensa"; Jane Christina Pereira. Estudo Crítico da Bibliografia sobre João Antônio (1963-1976); José Pereira da Silva Neto. O Espaço Urbano de São Paulo no Realismo Ficcional de João Antônio; Luciana Cristina Corrêa. Merdunchos, Malandros e Bandidos: Estudo das Personagens de João Antônio. Além desses trabalhos, vários estudos de iniciação científica foram concluídos e outras pesquisas encontram-se em andamento. A professora Dr. Ana Maria Domingues de Oliveira é quem coordena o arquivo.

79 João Antônio. "Meus Tempos de Menino" in A Dama do Encantado, São Paulo: Nova Alexandria, 1996, p.21. O Morro da Geada, segundo João Antônio, tinha vários nomes: da Continental, do Wilson, mas o nome oficial e o que ele considerava mais feio era Presidente Altino. João Antônio. "No Morro da Geada" in Zicartola e que tudo mais vá pro inferno!, São Paulo: Scipione, 1991, pp. 7 e 9
} 
Nesse morro de migrantes "que não haviam dado certo em parte nenhuma do mundo", para o qual retornou tempos depois, já como escritor, vivia com liberdade a ponto de não querer descer. ${ }^{80}$ Foi desse morro que escreveu sua primeira carta para a também escritora Ilka Brunhilde Laurito, em 1/09/1959: "Esta carta vem do último subúrbio. Do Morro de Presidente Altino, talvez seu desconhecido." ${ }^{11}$ João Antônio em seus textos autobiográficos, mais de uma vez afirmou:

Subir o morro era fácil; descer, já não era, não. O coração não pedia pra gente descer. Assim balangando, jongando, arteiro, cheio de marras era o viver espontâneo do morro. Completa liberdade, do balacobaco. ${ }^{82}$

De lá via os espigões da cidade e os arranha-céus, enquanto tomava os chás preparados pela bisavó Júlia, uma morena supersticiosa de cabelos muito lisos.

Vó Lula abominava orquídea dentro de casa. Orquídea era mau agouro, vento encanado, fio desencapado, asa negra, ziquizira. ${ }^{83}$

Também tinha o privilégio de conviver com a avó Nair, a filha de Júlia, a sarará de olhos azuis e mais doze tios e tias-avós. No morro tinha futebol, jogo de malha, criações, só não tinha água encanada, nem TV, nem aparelho de som. A luz era recente. Na memória do escritor, era um morro de batutas. ${ }^{84}$

João Antônio nasceu em São Paulo em 1937. Filho de um português transmontano chegado ainda bebê no Brasil, "e de uma mestiça do Estado do Rio, neta de negros", ${ }^{85}$ foi morador durante sua infância e juventude de vários cantos e recantos da cidade, para onde carregou o seu lirismo. Hora do lado de lá do rio, hora do lado de cá, sempre seguindo a várzea. Entre essas travessias, viveu a partir de 1944, no pedaço chamado por seu pai de Beco da

\footnotetext{
${ }^{80}$ João Antônio. "No Morro da Geada", op. cit., p. 9.

${ }^{81}$ Com essa carta começou uma grande amizade e uma profícua correspondência que duraria até 1982. As cópias das cartas podem ser encontradas no Arquivo João Antônio na UNESP de Assis, onde estão separadas em dois volumes. O primeiro de 1959 a 1965 e o segundo de 1965 a 1982.

82 João Antônio, idem, p. 8.

${ }^{83}$ João Antonio. "Meus Tempos de Menino", op. cit., pp.21

${ }^{84}$ João Antonio, idem, pp.21-3.

${ }^{85}$ João Antônio. "Paulo Melado do Chapéu Mangueira Serralha" in Dedo Duro, São Paulo: Cosac \& Naif, 2003. (1 $1^{\mathrm{a}}$ ed., Record, 1982), p. 83.
} 
Onça, na vila Pompéia, na várzea inundável, onde possuíam um pequeno armazém na Rua Caióvas (Caiowaa). ${ }^{86}$

O Beco da Onça é getulista, negro, negróide, mestiço, emigrante, cafuso, mameluco, migrante, pobre, operário, corintiano roxo e paulista da gema. ${ }^{87}$

Lá, "deslizava bem" com seu patinete e jogava capoeira com a meninada. ${ }^{88}$ Por incentivo do pai, músico de rodas de chorões e criador de orquídeas, tocava bandolim. Por imposição da mãe, que the escondia o instrumento, abandonou a incipiente carreira musical.

Que me lembre. Freqüentei de cedo, rodas de chorões e seresteiros, levado pela mão de meu pai. O velho sequer tinha escola primária completa. Mas tocava por música. Banjo, violão, cavaquinho, bandolim e os instrumentos de cordas que conheço. Todos.

Atarracado, mãos quadradas e grossas. Mas de onde haveria arrancado aquela sensibilidade? ${ }^{89}$

O córrego Aimberé, que passava ali pertinho, foi aterrado em 1954 pela prefeitura, mais da metade dos casarões velhos do Beco foram demolidos para o surgimento de "prédios de apartamento de bacanas." Mas então, João Antônio não estava mais naquele canto, mudou-se com a família em 1951 para a Vila Jaguará e depois, em 1953, para a Vila Anastácio, nas Ruas dos Botocudos, perto do depósito municipal de lixo, onde ainda adolescente trabalhou na Anderson Clayton como office boy.

Há fartum da refinaria de óleo, das fábricas de maisena, das fundições, dos fósforos da Fiat Lux, do Frigorífico Armour do Brasil, das serrarias, dos esgotos que desembocam e correm grossos, pelo rio Tietê, águas

\footnotetext{
${ }^{86}$ Antes disso seu pai tinha sido funcionário do Frigorífico Armour. Cf. João da Silva Ribeiro Neto. João Antônio (Literatura Comentada), São Paulo: Abril Educação, 1981, p. 3. Para dados biográficos sobre o autor ver também Maria Salete Magnoni. "João Antônio" in Rebeldes Brasileiros, n8, vol. 2. Revista Caros Amigos, São Paulo: Editora Casa Amarela e Rodrigo Lacerda. João Antônio: Uma Biografia Literária, tese de doutorado, Departamento de Teoria Literária e Literatura Comparada, FFLCH - USP, 2006.

87 João Antônio. Lambões de Caçarola (Trabalhadores do Brasil!), $3^{\text {a }}$ ed., Porto Alegre: L\&PM, 1977. Obs: o livro não possui numeração de páginas.

${ }^{88}$ Carta para Ilka B. Laurito, 24/08/1960.

${ }^{89}$ João Antônio. "Paulo Melado do Chapéu Mangueira Serralha" in Dedo Duro, op. cit., p.85.
} 
espessas, escuras, encalacradas de entulhos e arruinadas pelo óleo e pelas imundícies. Correm lerdas, pesadas. O rio fedido, a que atiram o nome indígena, é o maior esgoto da cidade.

Nas ruas monturos, proliferam moscas, ratos e insetos ruins. ${ }^{90}$

Estudava na Lapa, trabalhou na Armour do Brasil, andava de bicicleta em Moema, freqüentava a zona de meretrício e os salões de sinuca do Bom Retiro, fazia artes marciais na Liberdade, arrumou emprego em um banco na Lapa e depois numa agência publicitária no centro, fez o curso normal e a faculdade de jornalismo. No final da década de 50 , mudou-se para o Jaguaré. ${ }^{91}$ Cursou o Teatro de Arena. Era ouvinte nos cursos de literatura da Faculdade de Ciências Humanas da Universidade de São Paulo, na Rua Maria Antonia, assistia freneticamente o chamado cinema de arte. ${ }^{92}$

Filho de migrantes, percorreu com a população movente de São Paulo, os meandros da cidade numa espécie de "nomadismo" em busca de trabalho, moradia, lazer e estudo. Pelo caminho, depois de deixar o morro, foi criando seus "pedaços". ${ }^{93}$ Foi também conhecendo e recriando seus malandros e merdunchos. Percorreu com seu andar e sua escrita as várzeas paulistanas, ocupadas pelas derradeiras hortas, pelo futebol domingueiro, pelas lavadeiras e pelas favelas que começavam a crescer. As várzeas dos rios chamados com intimidade pelos nomes próprios: o Tietê, o Pinheiros.

\footnotetext{
${ }^{90}$ João Antônio. "Paulo Melado do Chapéu Mangueira Serralha" in Dedo Duro, op. cit., p.101.

${ }^{91}$ João da Silva Ribeiro Neto. João Antônio, op. cit, pp.3-5.

${ }^{92}$ Rodrigo Lacerda. João Antonio, op. cit., p.111. Carta para Ilka B. Laurito, 8/08/1960.

${ }^{93}$ Sobre a noção de "pedaço", ver José Guilherme Cantor Magnani. Festa no Pedaço, op. cit., p.12. O pedaço pode também ser entendido como o espaço onde se deposita a afetividade.
} 


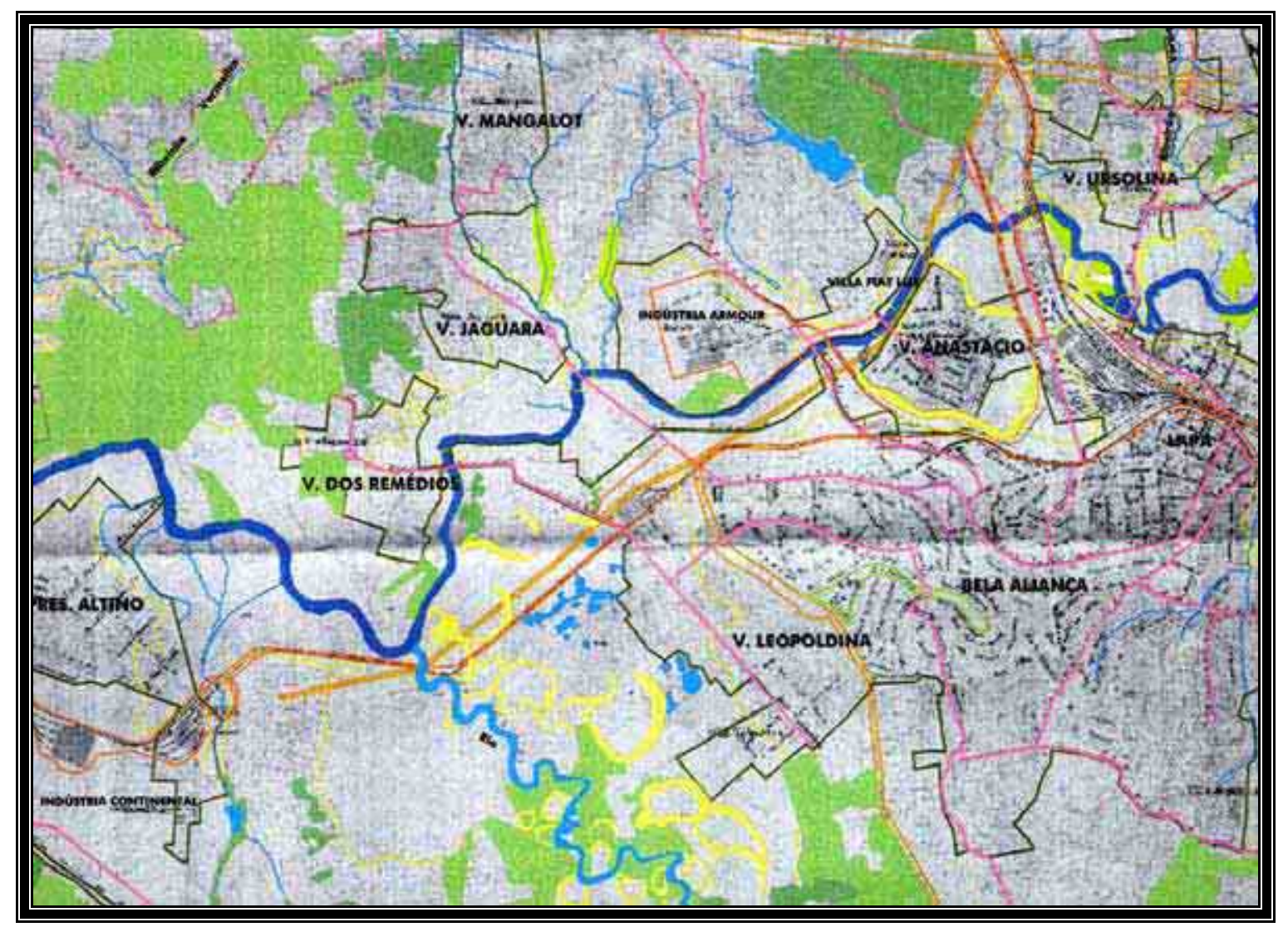

Imagem 7 - Várzea do Rio Tietê, 1930. Podemos ver já instalada a Indústria Armour e alguns dos bairros onde João Antônio viveu com sua família e circulou: Presidente Altino, Vila Jaguará, Vila Anastácio e a Lapa. $O$ rio ainda com seus volteios, antes da canalização. Fonte: Iraúna Bonilha. $O$ Desenho da Paisagem, op. cit., a partir de Mapa Topographico do Município de São Paulo, 1930. 


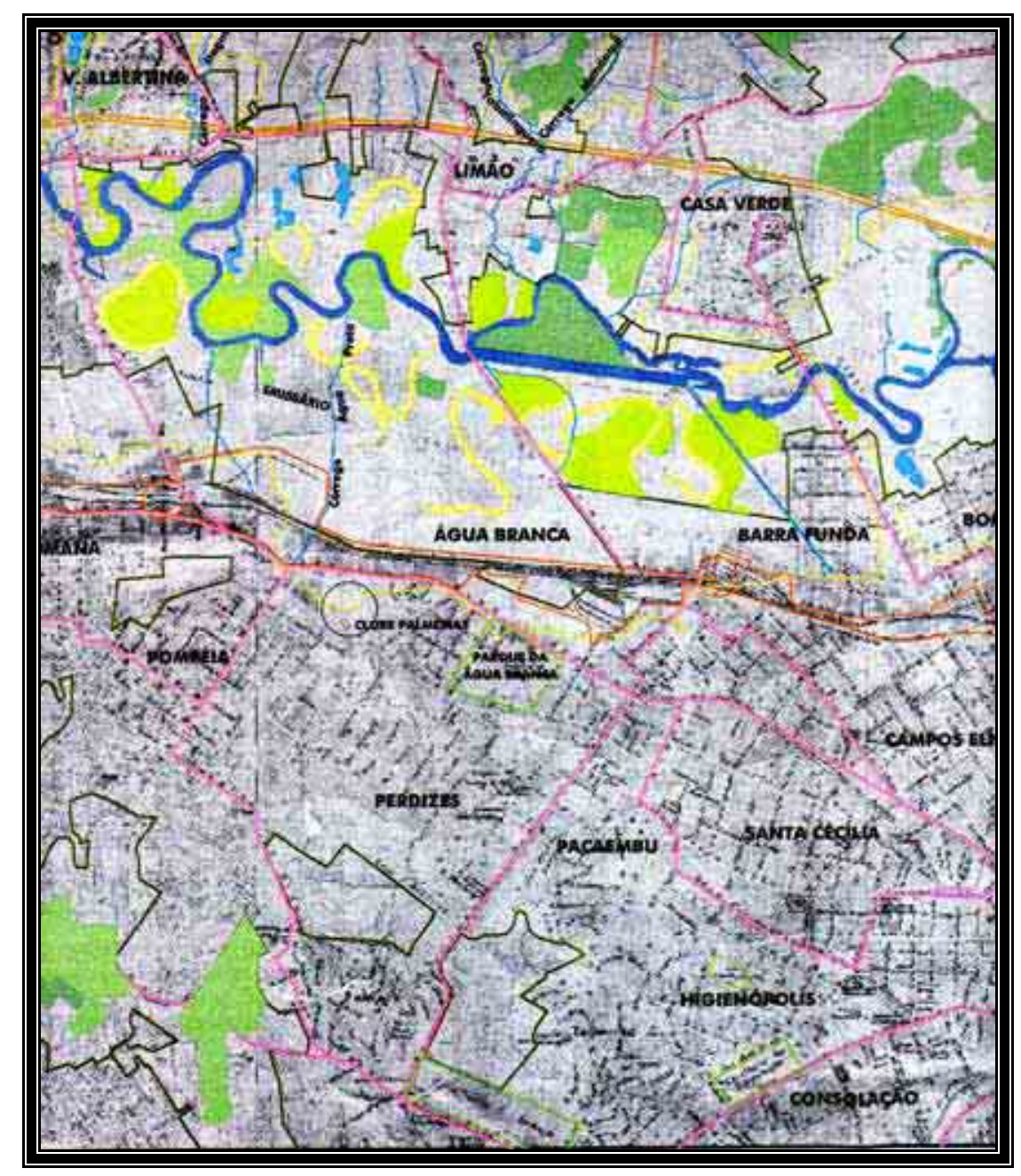

Imagem 8 - Várzea do Rio Tietê, 1930. Bairro da Pompéia, onde João Antônio viveu nos anos 40 atrás do Clube Palmeiras, no Beco da Onça. Fonte: Iraúna Bonilha. O Desenho da Paisagem, op. cit., a partir de Mapa Topographico do Município de São Paulo, 1930.

Seus personagens aprenderam com ele a andar, rodar, zanzar, zoar, perturbar, varar, ir, voltar, afinar sua arte de chutar tampinhas, fugindo à "semana brava" do subúrbio, porque, como escreveu em uma de suas cadernetas: "Um dia, como é longo e como passa." ${ }^{94}$ Essa gente, quando cansada, buscava consolo naquilo que a cidade podia oferecer como

\footnotetext{
${ }^{94}$ As cadernetas manuscritas de João Antônio, feitas com embalagens de cigarro, e primorosamente preenchidas com canetas de cores diversas, foram consultadas no Arquivo João Antônio, no Departamento de Literatura da UNESP de Assis. Em Carta para Ilka B. Laurito de 24/08/60 escreveu: "sinto uma vontade mesquinha - andar sem quê nem para quê. Rodar, zanzar, zoar, perturbar, ir, voltar, pegar uma rua e ir até seu fim e depois entrar por outra. Outra." Essa carta foi escrita algum tempo depois que a casa do escritor no Jaguaré pegou fogo. Nesse incêndio a família perdeu todos os seus pertences.
} 
entretenimento e um dos principais escapes, quando se tinha um pouco de capital, era o cinema. ${ }^{95}$

Andando tão devagar. Procurava alguma coisa na tarde. O vento esfriou. Não sabia bem o que, era um vazio tremendo. Mas estava procurando. Os ônibus passavam carregando gente que volta do cinema. Para essa gente de subúrbio mesquinho, semana brava suada nas filas, nas conduções cheias, difíceis, cinema à tarde, pelo domingo é grande coisa. ${ }^{96}$

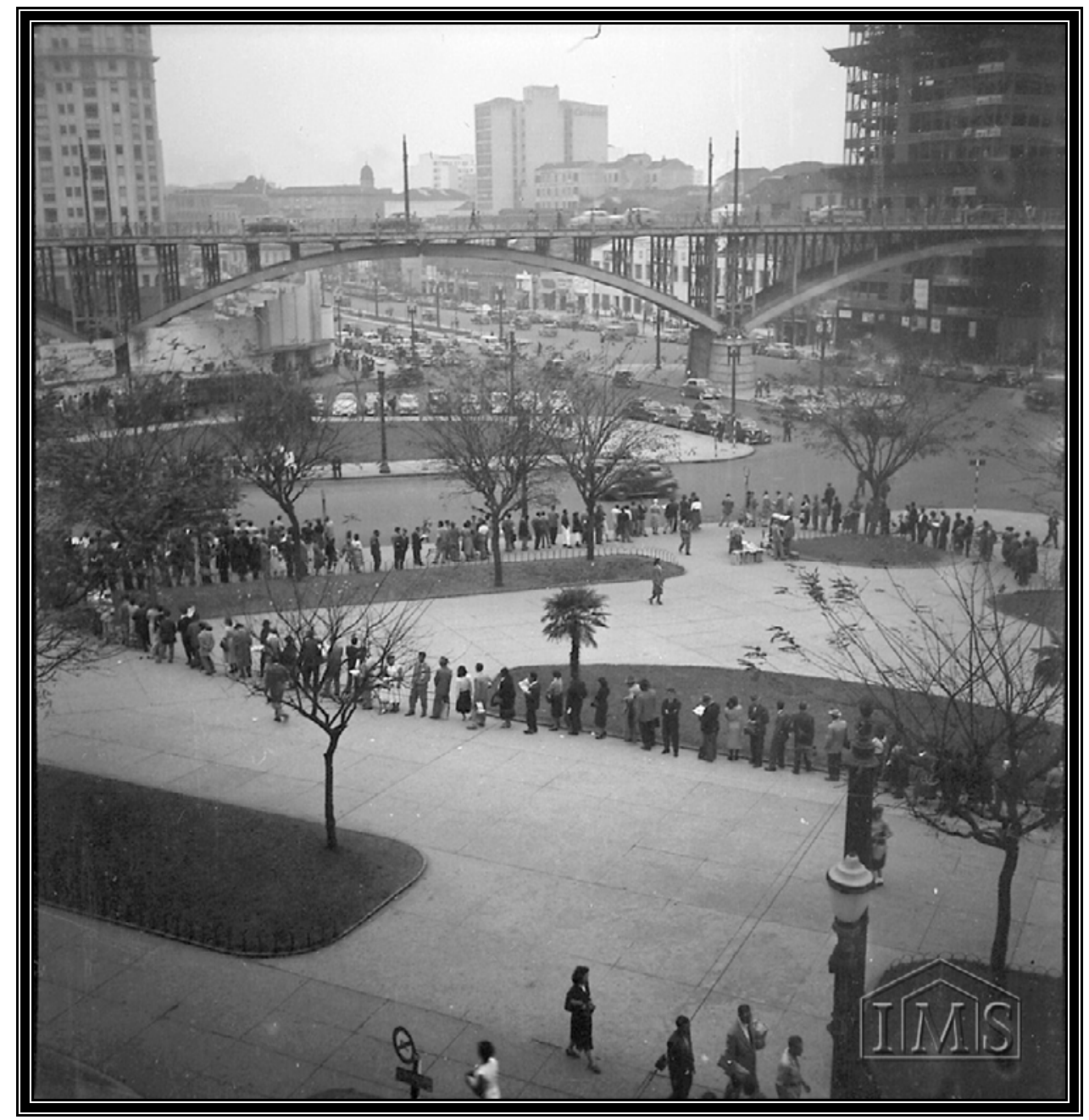

Imagem 9 - "Fila de ônibus no Vale do Anhangabaú”, São Paulo, 1953.

Alice Brill / Acervo Instituto Moreira Salles. Código: 011CXB3604

Mas os pesonagens de João Antônio sentiam febre, "Mas a febre" explicava - "era febre e queimava e dava pressa." 97 Essa febre, em sua literatura híbrida, transformava-se em deambulação. É bem provável que esses

\footnotetext{
${ }^{95}$ Como Ozualdo Candeias, João Antônio era um grande freqüentador de salas de cinema, como também Carolina e seus filhos.

${ }^{96}$ João Antônio "Busca" in Malagueta, Perus e Bacanalo, op. cit., p.31.

${ }^{97}$ João Antônio. "Malagueta, Perus e Bacanaço", op. cit., p. 189.
} 
seres de viração, como João Antonio os considerava, tenham cruzado em suas andanças febris com Carolina, moradora da favela do Canindé, na várzea do Rio Tietê e com os protagonistas de A Margem de Ozualdo Candeias. Talvez tenham mesmo trocado algum gesto ou olhar. ${ }^{98}$

Sapos nas pocinhas das beiradas do campo de futebol. Até há pouco, aquilo era do futebol da molecada. Indústrias querem surgir acompanhando a estrada de ferro, acompanhando tudo, provavelmente serão usinas de concreto. Várzea escura, breu. ${ }^{99}$

Seu primeiro livro, Malagueta, Perus e Bacanaço, publicado em 1963, traz um conjunto de contos que, escritos no final dos anos 50 e início da década de 60, traduzem esse sentimento de busca por algo, busca aparentemente indefinida. ${ }^{100}$ São contos de deriva, que têm na andança o ponto central. Nessa deriva incessante por São Paulo, por suas várzeas e colinas, seus personagens - operários, vagabundos, soldados, malandros, meninos -, como também o próprio João Antônio, foram demarcando os seus "pedaços".

Atravessei a ponte. Tinha trocados no bolso, me enfiaria num trem, acabaria na estação Júlio Pestes. (...) Eu queria andar. Desde que papai morreu, esta mania. Andar. ${ }^{101}$

Eles não flanam, observando o ambiente, eles percorrem conferindo sentidos, deixando marcas, interferindo, participando, e podem fazê-lo dessa forma por serem desenraizados. Como não jogaram âncoras em lugar algum, todo lugar pode ser investido de profundo sentimento, desde que permita a intervenção - o que se tornava cada vez mais difícil em uma cidade

\footnotetext{
${ }^{98}$ Sabe-se, por Carta para Ilka Laurito de 24/08/60, que João Antonio leu o livro de Carolina, Quarto de Despejo, mas não foram encontradas informações a respeito de um possível conhecimento da obra de Candeias, o certo é que João Antônio, sendo sócio da Cinemateca, conhecia cineastas que freqüentavam a Rua do Triunfo e mantinham contato com Candeias. Em Carta para Ilka B. Laurito de 6/10/61 ele disse que estava planejando, juntamente com Luis Paulino e Maurice Capovilla, um documentário sobre o Rio Tietê, e ainda com Capovilla um filme de ficção sobre esse rio, cujo título seria A Morte dos Luminosos. Esses filmes, entretanto, nunca chegaram a ser realizados.

${ }^{99}$ João Antônio. "Visita" in Malagueta, Perus e Bacanaço, op. cit., p.117.

${ }^{100}$ O livro Malagueta, Perus e Bacanaço é dividido em três partes: Contos Gerais, Caserna e Sinuca. A primeira parte é composta pelos seguintes contos: Busca, Afinação da Arte de Chutar Tampinhas e Fujie. Caserna tem Retalhos da Fome numa Tarde de G. C. e Natal na Cafua. A última parte: Frio, Visita, Meninão do Caixote e o conto principal Malagueta, Perus e Bacanaço.

${ }^{101}$ João Antônio. "Busca" in Malagueta, Perus e Bacanaço, op. cit., p.14.
} 
constantemente invadida pela intervenção oficial e, mais ainda, pela intervenção especulativa do mercado -, desde que reconheçam naquele espaço outros seres semelhantes a si. ${ }^{102}$ A dificuldade para os personagens de João Antônio parece estar justamente neste último ponto, eles são solitários, são seres esquivos que não se deixam conhecer por completo. Possuem uma subjetividade poderosa e sentem a falta do reconhecimento na grande cidade movente. João Antônio, porém, se reconhecia neles e em São Paulo. Neles encontrava seu espaço de solidariedade e com eles reconhecia a cidade que não parava de mudar.

No conto Busca, o protagonista, um operário pobre, ex-boxeador, narra, em primeira pessoa sua errância numa tarde domingueira pela cidade, buscando um preenchimento que não encontra. O tédio que parece carregar, entretanto, não traz como alicerce uma dúvida metafísica, é bem calcado no "pedregulho mal socado da rua", onde o sapato novo "subia, descia" e seu enternecimento pelo cair da tarde, rapidamente é suspenso pela urgência das tarefas diárias, como tirar o limo do tanque encardido em que sua mãe lavava as roupas da família. Tarefas que, contudo, nunca eram cumpridas devido ao improviso da vida. Improviso que João Antônio sabia perceber muito bem.

E essa prática do caminhar pela cidade dos personagens de João Antônio dava aos sapatos um destaque particular, eles recebem uma atenção muito especial: novo, de couro, emitindo o "plac-plac" na calçada, cheios de pó denunciando a falta de calçamento na várzea, rudes coturnos da caserna, tênis enlameados, os tênis furados do pequeno andarilho em "Frio", sapatos furados de Malagueta, sapatos brilhantes de Bacanaço. ${ }^{103}$

Não posso falar dos meus sapatos de saltos de couro...Nas minhas andanças é que sei! Só eles contatam, em solidão, que somente há crianças, há pássaros e há árvores pelas tardes de sábados e domingos, nesta minha cidade. ${ }^{104}$

\footnotetext{
${ }^{102}$ Para a diferença entre a flanerie de Baudelaire e Walter Benjamin e a dérive situacionista, cf.. Nicolau Sevcenko. "Dérive poética e objeção cultural", op. cit.. José Pereira da Silva Neto também concluiu que nos contos de João Antônio não se trata de flanerie. O Espaço Urbano de São Paulo no Realismo Ficcional de João Antônio, dissertação de mestrado, Departamento de Literatura, Faculdade de Ciências e Letras - UNESP, Assis, 2002.

${ }^{103}$ João Antônio. "Frio" in Malagueta, Perus e Bacanaço, op. cit., p.66. Maria Cristina Cortez Wissenbach abordou em um de seus estudos a importância dos sapatos para os negros livres, uma vez que na escravidão eles se constituíam em objeto interdito. Ritos de Magia e Sobrevivência. Sociabilidades e Práticas Mágico-Religiosas no Brasil (1890/1940), tese de doutoramento, FFLCH - USP, 1997, p.24.

104 João Antônio, idem, p. 24.
} 
Sapatos cheios de pó, sapatos cheios de pó, vivem sempre empoeirados. Porcaria de vila! ${ }^{105}$

Contudo, para ver os sapatos, objeto de distinção num país de passado escravocrata, era preciso abaixar o olhar. Do alto do morro, desde cedo, João Antônio aprendeu mais do que olhar para baixo. Aprendeu como olhar por baixo, prestando atenção onde pisava, enxergando as tampinhas que poderiam ser chutadas e afinando a arte, como em seu conto de rara inspiração. ${ }^{106}$

Há algum tempo venho afinando certa mania. Nos começos chutava tudo o que achava. A vontade era chutar. Um pedaço de papel, uma ponta de cigarro, outro pedaço de papel. Qualquer mancha na calçada me fazia vir trabalhando o arremesso com os pés. Depois não eram mais papéis, rolhas, caixas de fósforos. Não sei quando começou em mim o gosto sutil. Somente sei que começou. E vou tratando de trabalhá-lo, valorizando a simplicidade dos movimentos, beleza que procuro tirar dos pormenores mais corriqueiros da minha arte se afinando. ${ }^{107}$

Às espiadelas foi percebendo o que estava interdito, mas que, por isso mesmo, era mais tentador: as pernas das moças no bonde, que aprendeu a olhar com o tio, as tacadas certeiras nas mesas de sinuca, proibidas para sua idade. $^{108}$

Nem dá pra esquecer o tio alto, o ainda tio-avô Rubens, mulherengo de topo, bigode frajola, pobre, carioca, porém caprichoso nas roupas, empaletozado como na época, empertigado, namorador impenitente e alegre e, pioneiro, a me ensinar nos bondes a olhar as pernas nuas das mulheres e, após, Ihes oferecer o lugar. ${ }^{109}$

Espiando maroteiras no bar do Tico, bebendo misturas, ouvindo casos, um dia. Um é o primeiro. Nos fundos, havia duas mesas de sinuca e depois, em noite alta, a conversa continuava lá. Uma vez, catei o taco. Sem acreditar que viciasse. ${ }^{110}$

\footnotetext{
105 Joâo Antônio. "Visita" in Malagueta, Perus e Bacanaço, op. cit., p. 77.

106 'it is below - 'down' - on the threshold where visibility ends that the city's common practitioners dwellThe raw material of this experiment are the walkers, 'Wandersmanner', whose bodies follow the cursives and strokes of an urban 'text' they write without reading." $\mathrm{cf}$. Michel de Certeau. "Practices of Space", op. cit., p.124.

107 João Antônio."Afinação da Arte de Chutar Tampinhas”, in Malagueta, Perus e Bacanaço, op. cit., p. 41.

${ }^{108}$ Aos 16 anos foi supreendido pela polícia jogando sinuca, como fazia nos fins de semana à noite, no Bar do Tico, o que deixa seu pai desconsolado. Cf. João da Silva Ribeiro Neto. João Antônio, op. cit., p. 4.

109 João Antônio. "Meus Tempos de Menino", op. cit., p. 22.

110 João Antônio“Paulo Melado do Chapéu Mangueira Serralha” in Dedo Duro, op. cit., p. 108.
} 
Seus personages em São Paulo, também utilizavam o olhar indireto, como o menino que aprendeu a admirar o jogo malandro nos intervalos de suas brincadeiras ou quando roubava um pouco do tempo de suas idas à vendinha para buscar leite a pedido de sua mãe, aproveitando-o para vaguear por aí. Nos dias de chuva, o caminho se tornava muito mais atrativo, "o tênis pisava na água, pisava no barro, pisava na água, pisava no barro, pisava na água, pisava no barro, pisava... - Dá um litro de leite." Como não tinha, foi preciso ir até o bar desconhecido, o acaso da tempestade, fez com que por lá se demorasse um pouco mais.

No Paulistinha havia sinuca e só então eu notei. Pedi uma beirada no banco em volta da mesa, ajeitei o litro de leite entre as pernas.

- Posso espiar um pouco?

Um homem feio, muito branco, mas amarelado ou esbranquiçado, eu não discernia, um homem de chapéu e de olhos sombreados, os olhos lá no fundo da cara, braços finos, tão finos, se chegou para o canto e largou um sorriso aberto: Mas é claro, garotão! $!^{111}$

E assim, meio por acidente, com um pouco de sorte, habilidade e muita astúcia, o meninão tornou-se um ás. Tudo aprendido em silêncio a partir da primeira espiadela e depois seguindo, "resvalando, sorrateiro" pela madrugada, escorregando.

Seus personagens são os andarilhos que escrevem o "texto urbano", que não é feito de palavras, mas de passos, de entradas e saídas, de recuos, de rastros. Traçavam a dança dos viradores, pelas ruas atrás de parceiros para o jogo, mas também de algo mais. O peregrinar não é composto somente pelo que está faltando, mas é a própria substância de uma cultura.

Realmente não fui eu que os criou. A vida foi quem me deu. Deu por dar, simplesmente. Deu de graça, de presente. Eu os conheço todos eles e elas ainda vivem por aí e se agitam, se arrastam nas ruas. Todos, todas. Vagabundos, meninos, meninas, malandros, adúlteras, toda uma cambada de marginais, que a vida tem me dado de presente sem que eu pedisse. Mas eu os amo e os quero como se fossem meus filhos. E não posso tratá-los como padrasto. ${ }^{112}$

\footnotetext{
111 João Antônio. "Meninão do Caixote" in Malagueta, Perus e Bacanaço, op. cit., p.85.

${ }^{112}$ Carta para Ilka B. Laurito, 20/09/1959.
} 
João Antônio assombrava-se com a cidade. ${ }^{113}$ Mas, nos seus andaços, como sua mãe gostava de dizer, o que mais importava eram os pequenos espaços de viração. ${ }^{114} \mathrm{O}$ detalhe the importava mais do que o todo. $\mathrm{O}$ gesto mais do que a explicação racionalizada. $O$ afeto do lugar, mais do que a composição da paisagem. Entretanto, a confusão do mundo também o perturbava, da mesma forma que perturbava Carolina, escritora a qual aprendeu a admirar.

Quarto de Despejo - Diário de uma Favelada - é o livro de Carolina Maria de Jesus que faz pensar na vida, em São Paulo e faz pensar no Brasil. Ilka, porque nossas misérias hão de ser tão terríveis? O livro é povoado de coisas horriveis, tenebrosas, que chegam na ingenuidade emocionada de uma mulher que é escritora por vocação. Não tem alquimia literária e isso é um bem para ela. Sintaxe estrepada. Beleza grande nas descrições simples do arco-íris e da descrição bruta de uma fome que não é fome de Knut Hansen. Não é fome literária, nem é fome lírica. É fome de estômago, tão somente. Fome que vem em vários graus; às vezes, falta a banha para fritar a lingüiça.

A mulher, o livro da mulher, o lançamento do livro da mulher são acontecimentos revolucionários. Seu livro é lido e muito.

Muitos escritores fugiram e andam fugindo com medo do tamanho do talento e da ingenuidade de Carolina Maria de Jesus. Outros, menos calhordas, lêm a mulher e sabem aplaudir. Seu livro é um libelo e é de dorer que os homens do governo não façam nada. Não sei porque nunca fazem nada.

(...)

Poucos escritores compareceram à festa de lançamento. Por isso eu farei uma croniqueta para o Ceará com um título assim: "Um Coquetel sem Calhordas Literários". E depois farei outro sobre o livro. É."115

Para João Antônio, a confusão vinha da cidade vista como um todo, como desabafou com llka:

São Paulo é uma cidade terrível.

Já a chamaram de uma porção de nomes bonitos e razoáveis, mas nunca disseram que São Paulo é uma cidade terrivel. Engalanaram São Pauli várias vezes, desonestamente. E terrível é desde as quatro horas da manhã em que já é varrida, andada, rodada, bicicleteada por uma casta valorosa que se apressa aos bondes, aos lotações, aos papafilas. Os trabalhadores. Empurrando e empurrados e sem falar. Este convívio ciclópico, maquinal, ganha dimensão vertiginosa; contamina, se alastra. Às nove horas já é tudo confusão.

\footnotetext{
${ }^{113}$ Carta para Ilka B. Laurito, 6/6/60.

${ }^{114}$ Idem, 5/09/61.

${ }^{115} \mathrm{Idem}, 24 / 08 / 60$.
} 
Não é otimismo.

Em São Paulo não se anda. Nas ruas de São Paulo as pessoas correm e os lentos são contaminados, empurrados, levados em multidão...

Ninguém o conhece, ninguém se sabe, ninguém se tem.

A competição irracional se repete todos os dias, todos, $E$ o indivíduo se envenenando. Aos domingos, feriados, dias santos de guarda; dias de repouso? Pausa do delírio? Nada disso.

(...)

Ah, São Paulo! Dura e triste e sem remédio a solidão constante de suas multidões... ${ }^{116}$

Era terrível, especialmente, porque obrigava a pensar na passagem do tempo. Era uma cidade que apontava insistentemente para a irreversibilidade. Os migrantes urbanos, que se constituíam na matéria da literatura de João Antônio, tinham uma forte noção desse tempo, porque o deslocamento para eles era sempre mais temporal do que espacial. Quando se voltavam para olhar o que antes ali estivera, já não estava mais e isso denotava passagem de tempo. O espaço era o mesmo, mas transformado. ${ }^{117}$

Por isso era preciso, para apreender essa cidade, era preciso fragmentála, apreciá-la por partes, conhecê-la no seu mínimo de tempo-espaço e em suas durações. É isso que ocorre em um de seus contos de maior expressão: Malagueta, Perus e Bacanaço. Os três malandros, numa noite de sábado, percorrem um itinerário que começa e termina na Lapa, formando uma espécie de círculo mágico que sai da várzea em direção à colina, para depois retornar ao mesmo lugar. É um conto de duração e de tempo, aponta para um desfecho e retorna depois de concluído o contorno. ${ }^{118}$

O engraxate batucou na caixa mostrando que era o fim.

Bacanaço se levantou, estirou uma nota ao menino. Os olhos dançaram no brilho dos sapatos, foram para as cortinas verdes. ${ }^{119}$

\footnotetext{
116 "Recado de São Paulo", Idem, s.d., mas provavelmente de julho de 1960, por estar anexado a uma carta com essa data.

${ }^{117}$ Ilya Prigogine Prigogine em seu livro $O$ Nascimento do Tempo, op. cit., p. 19, salienta a importância de sua experiência de emigrado no seu trabalho sobre o tempo. Quem emigra tem sempre uma forte consciência da realidade do tempo. Na experiência da imigração, "Sentia-se, então, que o deslocamento tinha sido muito mais temporal do que espacial e de que o caminho inverso tornara-se impossível.", cf. Elena Pájaro Peres. A Inexistência da Terra Firme, op. cit., p.232.

${ }^{118}$ Como escreveu Wallerstein: "nem o acontecimento efêmero e microscópico nem a realidade eterna e infinita, cujo conceito é duvidoso, oferecem foco útil para uma análise inteligente. Se devemos alcançar uma compreensão significativa da realidade, convém mais nos determos no terreno do que designara como o terceiro não-excluído, simultaneamente tempo e duração, um particular e um universal, que são simultaneamente os dois termos e nenhum deles.", Immanuel Wallerstein. "O tempo, a duração e o terceiro não-excluído: reflexões sobre Braudel e Prigogine", in LOPES, Marco Antonio (org.) Fernand Braudel. Tempo e História, Rio de Janeiro: FGV, 2003, p. 75.

119 João Antônio. "Malagueta, Perus e Bacanaço" in Malagueta, Perus e Bacanaço, op. cit., p. 99.
} 


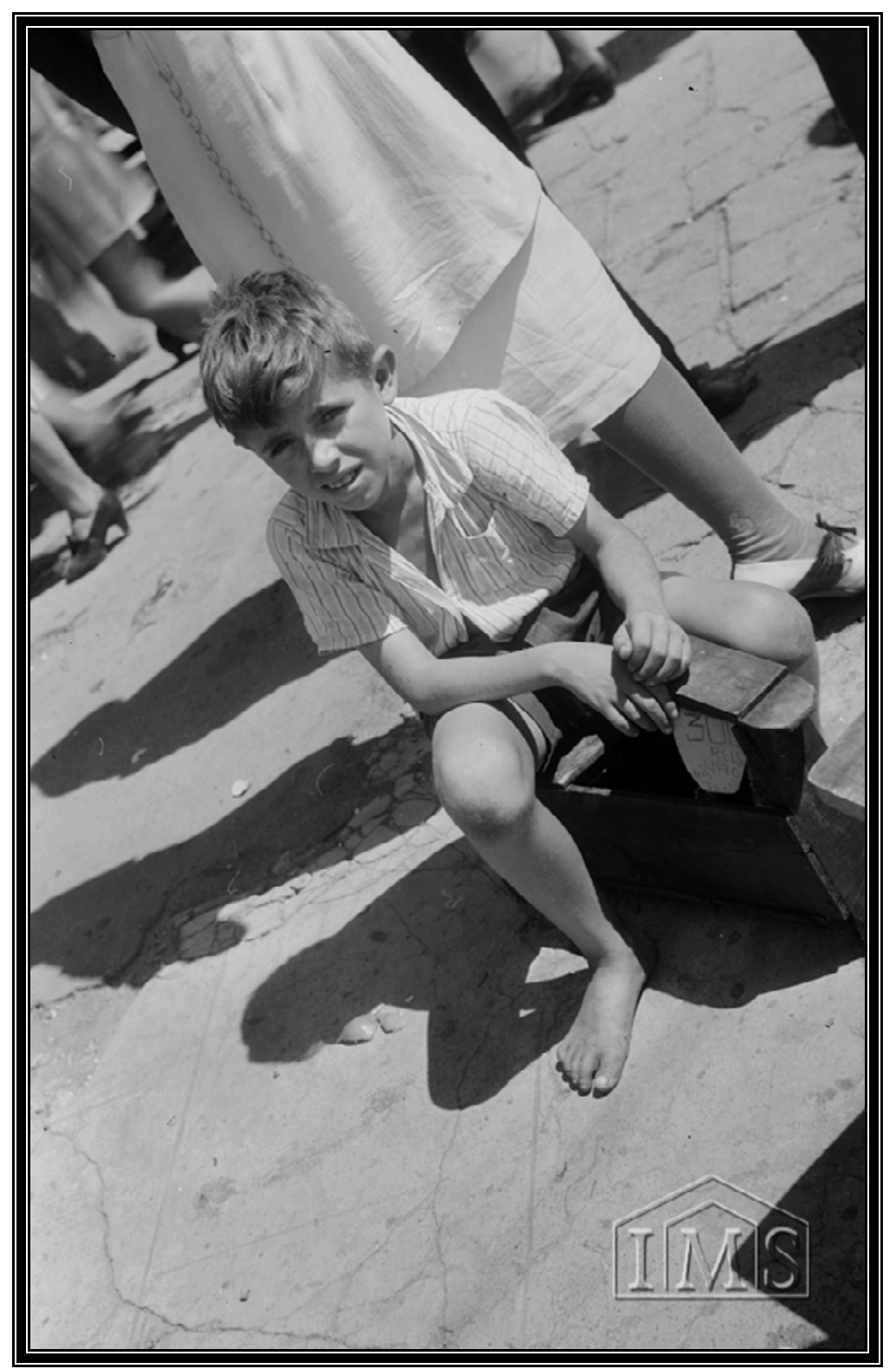

Imagem 10 -"Menino engraxate”, Feira Livre, São Paulo, SP, 1940.

Hildegard Rosenthal / Acervo Instituto Moreira Salles. Código: 005HRP085.008

Assim começa o percurso do mulato Bacanaço e seus comparsas, o jovem Perus e o velho Malagueta, que se encontravam diariamente na entrada do salão Velho Celestino, na beira da estação do trem, ao lado do Mercado da Lapa. ${ }^{120}$ Esse encontro se deu naquele dia sob os olhos do pequeno engraxate, que provavelmente ali ficou, a tudo assistindo, às espiadelas, em meio à agitação do final da tarde, com os mascates com suas carrocinhas ou panos no chão, apregoando suas mercadorias, quinquilharias sem fim, a rua

\footnotetext{
${ }^{120}$ A lei Municipal 3908, 1/07/50, assinada pelo prefeito Lineu Prestes, criou o Mercado Distrital da Lapa.
} 
suja e estreita, a porteira fechada, a algazarra, circulação, bondes lotados, buzinas, homens engravatados ou não, bicicletas, motonetas, caminhões, pedintes, muita gente vinda da Lapa de baixo, vinham do Moinho Velho, do Piqueri, de Cruz das Almas, de Vila Anastácio, vinham para o cinema, todo iluminado. Barulho de locomotiva, meninos jornaleiros gritando, choro de criança querendo sorvete. "A Lapa fervia." "A rua parece inchar."121

Estavam quebrados e combinaram rodar por todos os muquinfos da cidade, Água Branca, Pompéia, Pinheiros, Mooca, Penha, Limão, Tucuruvi, Osasco... Ganhariam o jogo no embuste. "Virariam São Paulo de pernas para o ar." A ordem era transgredir, virar, inverter, e começariam pelo Joana d'Arc na Água Branca. ${ }^{122}$

Um bairro após o outro, os vagabundos de João Antônio vão esquadrinhando a cidade, reconhecendo todos os bilhares, estudando o jogo, vasculhando as ruas. Eram reconhecidos também: “- Ô...”, saudação típica entre os tacos muito falados. Nas calçadas, pessoas sentadas balançando os chinelos, cachorro, tempo para lembranças. Até chegarem na cidade na hora "muito safada dos viradores", a madrugada. ${ }^{123}$ Após serem humilhados pelo tira Silveirinha no salão Paratodos, tiveram que ouvir a risada terrível que se espalhara pelo Largo Santa Ifigênia com um "sentir de quem perdeu", é nesse momento que de cima do Viaduto, Perus vê o vale.

Visto de cima, o Vale do Anhangabaú era um silêncio grande de duas tiras pretas de asfalto. O menino Perus olhou. Lindo, o Vale, aquele silêncio de motonetas paradas, de árvores e de carros em solidão. Lua lá em cima, o menino olhou. Já se percebia, á frente, o contorno do

\footnotetext{
${ }^{121}$ João Antônio. "Malagueta, Perus e Bacanaço", op. cit., pp. 104-5. O menino engraxate poderia ser o sr. E. N. que conheci em uma andança pela Lapa, em dezembro de 2004, em busca do salão Velho Celestino, do cinema, em fim, da ambiência do conto. O sr. E. N., a quem pedi informações, é trabalhador no Mercado da Lapa, viveu embaixo de uma ponte quando menino na favela do Piqueri, a mesma em que morava o personagem Malagueta. Costumava como um autêntico morador da várzea, atravessar o Tietê a nado na década de 50, juntamente com o irmão. Abandonado pela mãe ainda muito pequeno, teve que "se virar" sozinho. Não sabe ler, não conhece os contos de João Antônio, mas afirma que conheceu o malandro jogador "Carne Frita" de vista. Conheceu também os afamados contraventores Isaquinho, Esquerdinha e Sete-Dedos. Sempre viveu pelos arredores e, como menino de rua e engraxate, serviu, segundo ele na sua ingenuidade, de "comparsa" a esse trio, pois eles lhe davam moedas para que avisasse caso a polícia aparecesse. Ele ficava na porta dos bares observando. Costumava também engraxar sapatos na porta do Velho Celestino por alguns trocados. Vivia das sobras do Mercado e uma vez foi advertido quando roubava um pedaço de sabão.

122 João Antônio. "Malagueta, Perus e Bacanaço", op. cit., p.111.

${ }^{123}$ João Antônio, idem, pp. 120-126.
} 
Mosteiro de São Bento também sossegado no seu jeito antigo. Luz elétrica dos postes jogava uma calma... ${ }^{124}$

Por um curto instante, um encantamento surge no conto e o tempo estanca, mas não são os arranha-céus ao redor que isolados provocam a emoção, nem o viaduto velho, que por ser velho ficava solene, nem o mosteiro sossegado sozinho. Esses elementos apenas compõem o cenário quando em conjunto e preparam a cena, intensificando o conflito, matizando, denunciando tempo e duração "o viaduto velho, prédios novos", o vale. O vale é para onde se dirige o olhar. Mas é só um instante mínimo, quase imperceptível, mas profundo. Em seguida os vagabundos entreolharam-se, reconhecendo-se e lá embaixo um auto roncou firme, fazendo o tempo novamente rodar. Mesmo assim eles sabiam e acreditavam que "Haveria jogo em algum canto. Faziam fé." ${ }^{25}$ Como Augusto Matraga de Guimarães Rosa, cada um pensava por si: "a minha vez vai chegar."126

No final do conto, Perus novamente fica enternecido, agora com o nascimento do dia, e de novo cai no jogo, volta a dançar, chamado pelos parceirinhos.

Se num primeiro momento o que o encanta é a sensação de silêncio e quietude, nada funcionando, tudo parado, tempo parado, tempo encantado no vale. No final do conto o que o encanta é a certeza da passagem do tempo, o surgimento de um novo dia, que poderia trazer mudanças, mas que lhe dava a tranqüilidade do tempo cíclico que se abria para novas aventuras.

A história prossegue até o desfecho final que não é fim, é retorno, à Lapa, onde tudo começaria novamente. Assim também era na vida de João Antônio. Em um texto autobiográfico recordou a cidade através de seus passos:

\section{É andar. E andar.}

Osasco, Lapa, Vila Ipojuca, Água Branca, Perdizes, Barra Funda, Centro, Pinheiros, Lapa, na volta. Roteiro é este, com alguma variação para as beiradas das estações de ferro, dos cantos da Luz, dos escondidos de Santa Ifigênia. Também um giro lá por aquele $U$,

\footnotetext{
124 João Antônio, idem, p. 137.

125 João Antônio, idem, p. 140.

${ }^{126}$ Guimarães Rosa. "A hora e vez de Augusto Matraga”, op. cit., p.401.
} 
antigamente famoso, que se fazia entre as Ruas Itabocas e Aimorés, na fervura da zona do Bom Retiro. ${ }^{127}$

Percebe-se assim que Malagueta, Perus e Bacanaço é o traçado do roteiro afetivo do autor. Aqueles cantos pelos quais passava e, em movimento, deixava sua inscrição, são os mesmos em que seus personagens o acompanham. Não quis seguir só, organizou o espaço de acordo com o seu afeto e estabeleceu um roteiro de cantos.

Mas que eu não a achincalhe, afinal, fonte de ternura e, no fundo, comoção de antigamente, ela é uma cidade. Todos têm a sua e nasceram numa. Esta é a minha, queira ou não. Mais que geografia, um modo de vida. ${ }^{128}$

Mas um fato vai ficando líquido - andam matando a poesia das coisas. No entanto, parece-me que Calíope é bastante persistente e não morre mesmo. Então, coitadinha, Calíope moderna já não pode estar nas coisas belas, que as belas coisas andam mirradas. Calíope gruda-se então, nas feiuras e tristezas de um modo de poeira cinzenta, chaminés, arranha-céus, gente tonta lá embaixo, gente nos aviões a jato, na poeira, solidão, atribulação, tristeza e nada. ${ }^{129}$

Sua intenção parecia ser mesmo a de que seu canto resistisse ao tempo, preservando-se enquanto espaço e enquanto poesia. Como entoou ainda adolescente:

\section{UTOPIA NO PORTO DA FELICIDADE,}

Iremos então, bem equipados e com vontade dupla.

Abrirei as lâminas do Taro Adivinhatório

e gritarei que nossa sorte é boa

e o sibilo do vento não me abafará os brados.

E a vida rirá de ébria...

Riremos com ela.

E nascerá uma chusma de querubins que rir-se-ão todinhos.

Daí então, fingirei acreditar na Virgem

Erguerei os meus odes de júbilo

Preexistirá a ufania ao som

Nesse dia, medrará água da pedra

\footnotetext{
${ }^{127}$ João Antônio, Abraçado ao meu Rancor, São Paulo: Cosac \& Naif, 2001, p. 72. (1 ${ }^{\text {a }}$ ed. 1986)

${ }^{128}$ João Antônio, idem, p. 86.

${ }^{129}$ Carta para Ilka B. Laurito, 20/09/1959.
} 


\begin{abstract}
E os meus cantos resistirão ao Tempo.
Eu fingirei crer na Virgem

E estaremos no porto da felicidade
\end{abstract}

O mundo nos irá abençoar muito... ${ }^{130}$

Mas como seria possível entoar um canto e, ao mesmo tempo, preservar um canto em meio aos mais desesperados?

Plínio Marcos, santista do bairro portuário do Macuco, da Rua das Laranjeiras de chão de terra firme, mais do que procurar a resposta, formulou com sua obra essa questão. ${ }^{131}$ Numa de suas crônicas para o Jornal Última Hora de São Paulo, publicada posteriormente no livro Histórias das Quebradas do Mundaréu, pode-se vislumbrar a tênue possibilidade de um ligeiro, mas por isso mesmo, sincero, momento de crença e satisfação. Embaixo de um viaduto, em um vale qualquer, em fins dos anos 60.

Foi no verão, por acaso, que o velho pedinte descobriu o buraco debaixo do viaduto. Estava dando uma bandola, uma noite, assim como quem não quer nada, e, de repente, o rapa piou na parada. Pra se livrar do arrastão, ele se picou entre os enormes pilares e deu num buraco que estava escancarado bem na sapata de uma das colunas. Parecia uma toca de bicho, ou uma cova. Mas, naquela hora de apuro, o velhote não quis nem saber. Com a cana na sua captura, ele não vacilou. Se meteu no buraco e se quietou, (...).

Nessa noite, o velhote já puxou o ronco no buraco. E achou o fino. Assim que acordou, foi a um terreno baldio onde escondia seus cacarecos e fez a mudança definitiva pro buraco. Foi fácil transportar suas bugigangas. Era tudo coisa pouca.(...)Aquela cova Ihe dava uma segurança que antes o desgraçado nunca tivera. $(. . .)^{132}$

Até que um dia, descobriram o seu canto, precário e sujo, onde ele havia depositado os seus parcos bens: uma garrafa, uma lata e dois cobertores. No inverno, "Aquilo ali era o sonho de todo vagau." A montoeira de gente que se

\footnotetext{
${ }^{130}$ João Antônio Ferreira Filho. Jornal do Povo, $\mathrm{n}^{\mathrm{o}}$ 226, Itápolis, SP, 30/10/55. No acervo de João Antônio, em Assis, encontrei entre suas coisas um quadrinho para pendurar do Padre Donizetti.

${ }^{131}$ Sobre a obra de Plínio Marcos enquanto cronista de um tempo mau, como ele mesmo se intitulava, um excelente trabalho é o de Contreras, Maia e Pineiro. Nele, entremeada à análise das crônicas, há uma série de informações biográficas importantes para a compreensão da obra de Plínio. Os autores apontam que o bairro do Macuco em Santos, nos anos 40 e 50, era super populoso, repleto de casarões e cortiços, As diversões mais comuns eram a sinuca, os prostíbulos ao redor, o futebol de várzea. Cf. Javier Aranciba Contreras; Fred Maia eVinícius Pinheiro. Plínio Marcos; A Crônica dos que não têm voz, São Paulo: Boitempo, 2002.

${ }^{132}$ Plínio Marcos. "O Buracão" in Histórias das Quebradas do Mundaréu, São Paulo: Editora de Cultura, 2004, pp. 156-157, (1ª ed., 1973).
} 
apinhou no buraco, impediu que ele lá permanecesse no mais rigoroso dos frios. De lá ele foi pro abrigo, mas deu a dica para a assistente social, cagüetando o lance do buraco e a multidão de "lesados da sociedade" que lá se encontrava, se contorcendo de frio. A mocinha, querendo mostrar serviço, fez o recolhimento de todo pessoal que, na bronca, foram arrastados para a instituição. "No abrigo, a moça, certa de que estava abafando, apontou o velhote: - Foi ele quem se lembrou de vocês." E esse foi o fim de um velhote sem eira nem beira, que só pretendia um canto.

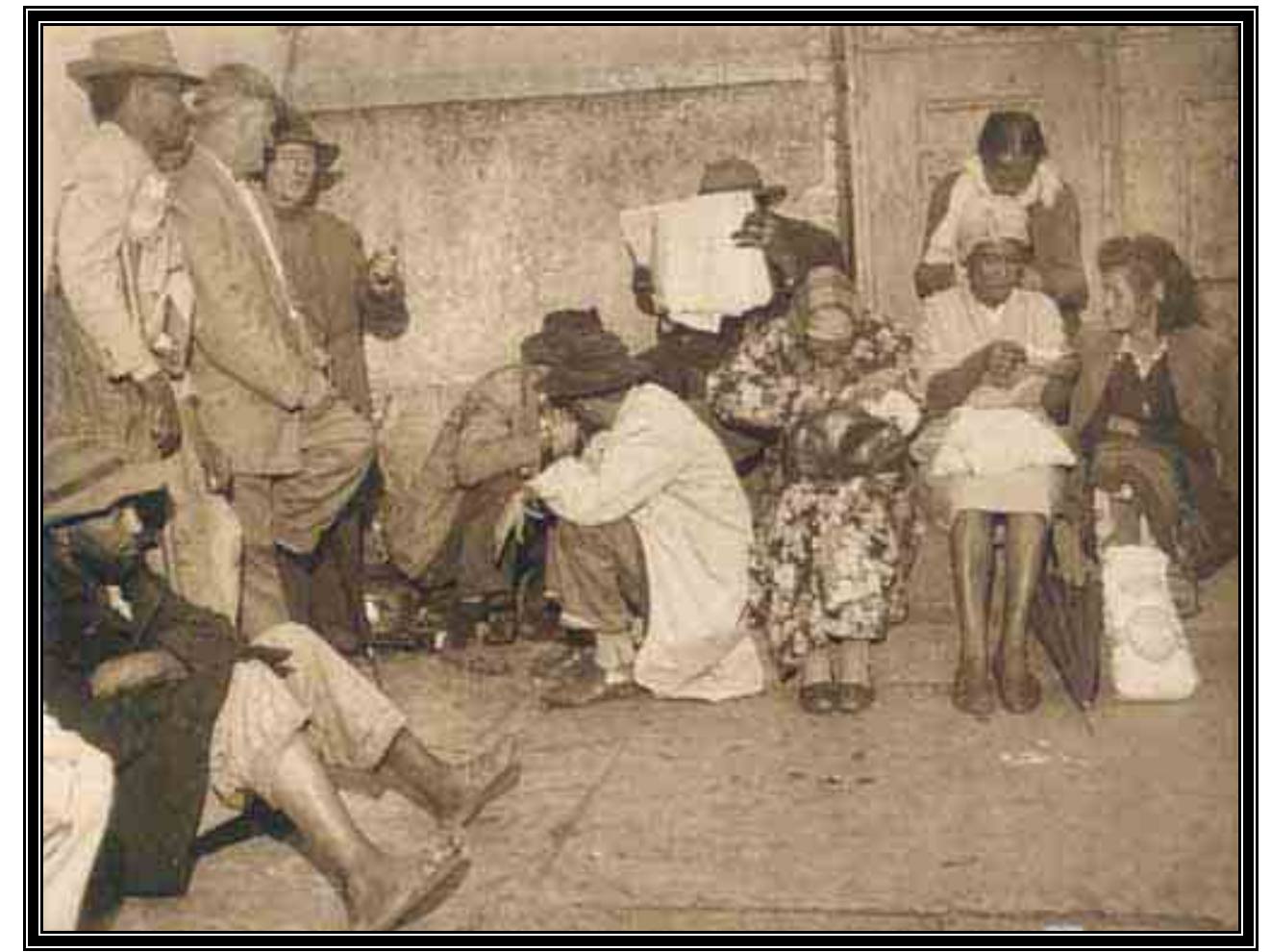

Imagem 11 - Espera na porta de Abrigo Noturno da Prefeitura, São Paulo, 1960. Jornal Última Hora, 30/05/1960 / Arquivo do Estado de São Paulo. Arquivos EspeciaisIconográfico.

Código: ICO-UH 1662 - Assistência Social.

Criado em meio às canções da liberdade dos marinheiros e acostumado à solidariedade no empréstimo de alimentos entre vizinhos, Plínio Marcos, na Rua das Laranjeiras brincava com as outras crianças, enquanto os homens ficavam no boteco e as mulheres na porta de casa trocando receitas. Era gente aparentemente pacata, que, num determinado dia, esperou os homens da prefeitura virarem as costas para arrancarem a placa com o nome do figurão 
que substituiria o antigo nome do pedaço. A rua continuou sendo das Laranjeiras, mas a partir daí, das Antigas Laranjeiras, pois era preciso marcar o acontecimento, a fúria imediata. ${ }^{133}$

Como ele gostava de dizer, aquele bairro, o Macuco, era uma universidade de cultura popular. Sua mãe chamava-se Dona Hermínia, seu pai era o Sr. Barros. Sua avó Lucila fazia xarope de agrião com palavras mágicas. Enterrava na Lua Crescente e desenterrava duas luas além. ${ }^{134}$

Vovó Lucila, quando me via taciturno pelos cantos, me pegava, me sentava em seu colo e me rezava contra quebranto.

- Que os males deste menino vão todos por esses mares afora, que neste corpo não tem lugar.

Eu me arrepiava todo, enquanto ela benzia. Depois eu sentia uma enorme paz. A vovó Ana Angélica tinha uma grande energia, uma Bíblia, (...) $)^{135}$

Foi com essa gente do Macuco que ele considerava ter aprendido a canção. Sua afetividade estava toda lá, naquela pequena casa verde, com bichos no quintal, flores e sombras.

Essa eu colhi com o coração. Uma coisa minha. Um chalé verde, lindo, com o batente da janela comido de cupim. As galinhas. A vermelha, a piolhenta, a sempre choca, a mãe de todas. E o cheiro das flores do jardim. $E$ os miosótis. Lindo miosótis. Não cantaria pra ninguém a canção das angolinhas. Cantaria um samba do Geraldão Filme: (...)."136

Vivendo bravamente como todo menino criado nos chalés da cidade portuária, Plínio pôde experimentar desde cedo as mais excitantes aventuras, como, por exemplo, saquear o caminhão de balas Futebol só para achar a figurinha difícil e depois comer todas as balas, escondido no porão, até passar mal, em busca da tal figurinha.

Mas eu fui pra trilha no tempo certo. Uma tristeza, uma melancolia incrível sem nenhum motivo. Minha casa, meu pai, minha mãe, meus irmãos. Nenhum conflito de convívio. Mas um terror de levar uma

\footnotetext{
133 Plínio Marcos. "Figurinha Difícil" in Figurinha Difícil: Pornografando e Subvertendo, São Paulo: Editora SENAC, 1996, pp. 29-33.

${ }^{134}$ Plínio Marcos. "Prisioneiro de uma canção" in Prisioneiro de uma Canção, 2a ed., São Paulo: s.e., 1982 , p.70

${ }^{135}$ Plínio Marcos, idem, p.69.

${ }^{136}$ Plínio Marcos, idem, p. 15.
} 
existência pacata, com emprego fixo, burocracia e horário. Então fui para o circo. Eu achava que tinha que ser artista. Palhaço. Ator. Fama. $^{137}$

Colocou-se cedo na trilha, com um certo pesar, mas, ao mesmo tempo, com o sentimento de que era a necessário fugir da rotina brava que ameaçava pôr fim às suas diabruras de menino, tirando toda graça da história. Realizou sua passagem indo para o Pavilhão Teatro Liberdade, um circo-teatro, "uma espelunca", onde começou a carreira de palhaço e ator. ${ }^{138}$ Anos após, interpretando o porquê de sua opção, concluiu:

Eu não entrei na trilha dos saltimbancos por acaso. Nem para ser um reles fazedor de graça. Eu queria consagrar minha vida através do ofício que escolhi obedecendo a um imperioso apelo vocacional. ${ }^{139}$

Essa consagração da vida ele fez de forma radical, abandonando a escola muito cedo, não suportando qualquer tipo de "esculhambação". Isso o levou a deixar o seu canto ainda jovem, mas não sem carregar consigo uma canção que ficava irremediavelmente tilintando em sua mente, como herança imaterial de uma outra geração com a qual ele teve a felicidade de conviver. Era uma canção doce e terna, boba até, recolhida através de sua mãe, carregada de cultura. Ela o envolvia "no seu ritmo, vultos, cheiros, cores ruídos", a partir dela ele poderia compor outras e muitas outras.

Essas histórias que eu sei...Essas sombras que bailam ao som da minha canção... Será que se eu me livrasse da minha canção eu perderia minha memória, minhas histórias? Qualquer libertação da um puta medo. Sei tanta bobagem e tenho medo de me livrar delas. ${ }^{140}$

O que se tem, a partir dessa criação poética de Plínio Marcos, é uma imagem de camadas de cultura em deslocamento, transbordando pelo balanço da deambulação, esparramando-se nos locais por onde passa a caravana, carregada numa espécie de tonel que se pode prender ao corpo ou incorporar aos gestos. Não depende de propriedade, posse ou paradeiro, depende sim de imaginação, lembrança, troca, reinvenção, desejo. E é no

\footnotetext{
${ }^{137}$ Plínio Marcos. "Na trilha dos bichos de São Sereré” in Prisioneiro de uma Canção, op. cit., p.54.

${ }^{138}$ Plínio Marcos. "Mestres Fingidores" in Figurinha Dificil, op. cit., p. 37.

${ }^{139}$ Plínio Marcos. "Pornografando e Subvertendo" in Figurinha Dificil, op. cit., p. 97.

${ }^{140}$ Plínio Marcos. "Prisioneiro de uma canção" in Prisioneiro de uma Canção, op. cit., p.18.
} 
transbordamento que se dá a intersecção cultural. Mas a passagem da caravana incomoda aqueles que não estão em movimento.

Os andarilhos sempre incomodam. Arrebentam as estruturas. Não são como os homens prego, que vivem com medo do ridículo, com seus empregos ameaçados. Até os que berram, dando ordens com suas vozes esganiçadas, vivem com medo. Têm espinhas nas gordas bundas, que suam nas cadeiras do poder. Todos eles. Chefes. Chefetes. Têm uma vida de merda. Têm compromissos com a velhice, com a doença e com a morte. ${ }^{141}$

A agressividade presente nos textos de Plínio era feita desse transbordamento, era aquela que não se continha diante do que considerava embotamento e submissão. Por isso mesmo, não se satisfez na literatura, não conseguia se deter em palavras, necessitava ser extravasada corporalmente, de maneira exuberante e incontida, a qualquer preço, e o caminho encontrado para isso foi o circo, foi o teatro, foi a música. Num momento histórico em que a euforia se desfazia em discursos de planejamento e massificação, a presença cáustica de Plínio e seus personagens assumiram a tonalidade do maldito.

Começou com Barrela, 1959, que foi apresentada na época uma única vez e depois censurada por ser considerada imoral, apesar dos elogios da crítica. Depois de outras tentativas infrutíferas, resolveu deixar Santos, mudando-se para São Paulo, onde amargou fome e incerteza. Tornou-se mais conhecido a partir de Dois Perdidos Numa Noite Suja (1966) e Navalha na Carne (1967). Enquanto Dois Perdidos era exibida no Teatro de Arena, por volta de 1966, um fato inusitado aconteceu e é narrado no livro A Crônica dos que não tem Voz, a partir da entrevista que os autores fizeram com a exesposa de Plínio e atriz Walderez de Barros. A peça que expõe o conflito entre dois homens que disputam um par de sapatos, dispostos até a matar por ele, parecia muito cruel por expor de maneira cáustica a sociedade da distinção e do privilégio, a deputada Conceição da Costa Neves não se conformando com isso, resolveu criticar abertamente o trabalho nos estúdios da TV Tupi, em um programa ao vivo. Para ela, a peça deveria ser censurada. Plínio que assistia tudo pela televisão foi até o auditório da Tupi, onde havia trabalhado, invadiu o programa e gritou: "Escuta aqui, sua vaca velha. Como é que tu fala do que

\footnotetext{
${ }^{141}$ Plínio Marcos. "Pornografando e Subvertendo" in Figurinha Dificil, op. cit., pp.95-6.
} 
não viu, do que não conhece? Tu não viu a peça. Pra fazer a crítica tem que ver. Se não assistir não pode falar" ${ }^{142} \mathrm{O}$ curioso desse evento, é que trata-se da mesma deputada que tentou em 1955 transferir as bençãos do padre Donizetti para São Paulo. Esse episódio teve grande repercussão, lotando o teatro de Arena nas apresentações de Dois Perdidos.

Outro fato que deu impulso à peça foi a declaração de Dom Hélder Câmara, por ocasião da estréia da peça em Recife: "Essa peça do Plínio Marcos vale muito mais que vários sermões e até missas.' "143 Os elementos profundos de religiosidade contidos na obra de Plínio e explicitamente assumidos por ele em diversas entrevistas, foram em geral desconsiderados pela crítica, sendo vistos como elementos menores diante da violência exposta cruamente em cada cena. ${ }^{144}$ Sempre foi mais fácil aceitar que a obra de Plínio Marcos tem uma ética humanista do que perceber a religiosidade que escorre de seu trabalho e transcende as normas estabelecidas pelo cânone cristão. ${ }^{145}$

Sua aproximação com o samba e a encantaria afro-brasileira desde os anos 60 está expressa em seus textos memorialísticos e na sua ficção. Um exemplo é essa conversa que teve com Geraldo Filme, o sambista do Largo da Banana em São Paulo e muito seu amigo:

- É verdade. Tu é bem chegado na raça. O crioléu gosta de ti. E os homens tão toda hora na tua captura. Vai hoje mesmo. Lá na Vila Guarani, em Santos, tem uma mãe-de-santo que é raspada na Bahia. Dona Irene. Chega lá, diz que foi o Geraldão da Barra Funda que mandou. O terreiro dela fica na quebrada. Mas não tem medo. Tu vai na proteção da roça dela. Se alguém puser a cara contigo, tu diz onde ta indo. Fica tudo tranqüilo, pode crer. Não esquece. Mãe Irene.

Cismei que ia. Fui. (...) Peguei o ônibus pro Jabaquara. Desci no ponto final e fui a pé pra Vila Guarani. Puta pirambeira! (...) O Geraldão era nome do pedaço.

[A entrega do despacho era na Avenida Jabaquara.]

- Mas lá é muito claro.

-Assim é que tem que ser. Você é artista, tem que ficar iluminado.

\footnotetext{
142 Javier Aranciba Contreras; Fred Maia e Vinícius Pinheiro. Plínio Marcos; A Crônica dos que não têm voz, op. cit., pp.57-8.

${ }^{143}$ Plínio Marcos. "Na Universidade do Povo" in Figurinha Dificil, op. cit., p.61.

${ }^{144}$ É o caso de Paulo Roberto Vieira de Melo que reconhece a dimensão religiosa de Plínio apenas depois de Barrela, mas a estabelece no plano da metafísica e do cristianismo, mesmo assim considerando que o misticismo foi um elemento que atrapalhou o trabalho posterior do dramaturgo. Plínio Marcos: A Flor e o Mal, Petrópolis: Firmo, 1994, pp. 32-3.

${ }^{145}$ Idem, p. 47.
} 
Disse a mãe Irene, e o resultado foi que Plínio foi preso fazendo despacho na encruzilhada. Nos jornais a manchete: "Plínio Marcos preso fazendo macumba."146 O delegado se espantou. "Te conheço como comunista e você me aparece como macumbeiro. Vai com Oxalá, que eu também sou da fé."147

Entretanto a magia maior para Plínio estava no próprio canto dos andeiros, aqueles com os quais ele aprendia os parangolés da vida, deslocando a atenção do discurso da conformidade e da aderência e direcionando seu olhar para os conteúdos humanos e desejantes que estavam nas ruas, fosse em Santos ou São Paulo. Aqueles que se encontravam nos desvão mais obscuros, encolhidos nos mais escondidos e esquisitos buracões e nunca por muito tempo, aqueles pra quem a vida não deu colher de chá, mas que em suas intervenções pela cidade deixavam um rastro que, por ser terrível, não deixava de ser encantado, acreditando sempre no choque do retorno dos ciganos, que nada mais é que a crença na sua hora e sua vez, quando a justiça se fará. O passado tornado de novo presente.

Não estou sujeito as leis do reino da banalidade. E esse não estar é justamente o fascínio. O encanto, a magia, o mistério da vida dos andeiros. E esse andar sem termo, um constante convite para a delirante fuga da rotina, para o sonho profético, para a poesia. ${ }^{148}$

Porém... na trilha não se exige atestado de boa conduta, carta de bons antecedentes tirada na polícia, com firma reconhecida em (p.23) cartório. Ninguém conferia ninguém. Na viagem sem termo, antes foi antes, agora é agora, e o que virá? O choque do retorno se encarrega da justiça. Infalível. Nisso podem crer. ${ }^{149}$

Os ciganos, com quem Plínio conviveu em sua época de circo e sobre os quais escreveu, representavam para ele a raiz em movimento, a possibilidade de viver em comunidade, mesmo sem um lugar permanente. Essa era uma alternativa para romper $o$ isolamento, sentido cada vez mais

\footnotetext{
${ }^{146}$ Plínio Marcos "Na Universidade do Povo” in Figurinha Dificil, op. cit., pp. 66-7.

${ }^{147}$ Plínio Marcos. "Na trilha dos bichos de São Sereré" in Prisioneiro de uma Canção, op. cit., p.59.

${ }^{148}$ Plínio Marcos. Na Trilha dos Saltimbancos, São Paulo, Marba, s.d., p. 5.

${ }^{149}$ Idem, p. 24.
} 
fortemente nas cidades, e em especial em São Paulo, para onde Plínio se dirigiu e de onde produziu a maior parte de sua obra. ${ }^{150}$

"Pra gente da viagem, não há onde ir. Nada a alcançar. Só o idiota precisa de meta. Quem entende isso entende o caminho dos santos e dos demônios. Não se amarram. Quem se agarra está agarrado. E lá iam eles. Para cada cigano que morria, para cada cigano que desertava, um gadjo (não cigano) era admitido no bando." Assim foi contratado também, juntamente com o palhaço Pipo e outros."

E como se daria a hora esperada, aquela que não tem fim, que quando termina, retorna? Talvez na favela encantada de Catimbó, onde a criação se inverteu e se fez no vale de algum rio paulistano, na várzea, situada nas quebradas do mundaréu, "lá onde o vento encosta o lixo e as pragas botam os ovos, nos atalhos esquisitos, estreitos e escamosos do roçado do bom Deus." 152

Até que no entardecer do sétimo dia, eles pararam na beira de um regato de águas cristalinas e contemplaram o lugar, que era muito bonito. O regato corria num chapadão que ia acabar na encosta de um morro. Exausta, a Nega Bina caiu ao lado do Catimbó. Ele permaneceu em pé, olhando tudo, até seus olhos se fixarem no horizonte. Nesse momento, a Nega Bina começou a chorar e a soluçar. O crioulo se enterneceu com os soluços da companheira. Uma estranha força Ihe brotou na alma. E o Catimbó berrou na direção ao céu: - Malei-me, Ogum meu pai. Perdão. Eu sou quem sou porque desde pequeno ando nas quebradas do mundaréu. Matei e morri mil vezes. Morri de fome, morri de sede, morri de frio, morri de ver minha gente morrer. Agora estou farto. Me dá malei-me, meu pai. Me dá tua valia. Perdoa as maldades que fiz. Me dá descanso e também pra Nega Bina, minha companheira. Deixa nós em paz neste lugar bonito como eu nunca tinha visto antes. E permite que a gente crie filho nesta terra de Oxalá. Malei-me, meu pai Ogum.

Ao acabar sua oração, as lágrimas rolavam pelo duro rosto do Catimbó, que ficou imóvel como que esperando uma resposta dos céus. (...) E a noite foi descendo mansamente e a primeira estrela brilho no céu. Ao ver a estrela, o Catimbó sorriu. Aí, caiu por terra e dormiu. (...)

Despertaram com o Sol forte batendo sobre eles. Estavam imundos de lama. Mas estavam alegres. Sorriram um para o outro e foram se lavar no regato. (...) Por fim, o Catimbó falou:

\footnotetext{
150 “A integração no sistema deve recuperar os indivíduos isolados como indivíduos isolados em conjunto: as fábricas e os centros culturais, os clubes de férias e os 'condomínios residenciais' são organizados de propósito para os fins dessa pseudocoletividade que acompanha também o individuo isolado na célula familiar: o emprego generalizado de aparelhos receptores da mensagem espetacular faz com que esse isolamento seja povoado pelas imagens dominantes, imagens que adquirem sua plena força por causa desse isolamento." Guy Debord. A Sociedade do Espetáculo, op. cit., tese 172.

${ }^{151}$ Plínio Marcos. Na Trilha dos Saltimbancos, op. cit., p. 26.

152 Plínio Marcos. Histórias das Quebradas do Mundaréu, op. cit.
} 
- Tu é de fé, Bina. Por isso, eu juro: se Ogum permitir, com a força da tua gama, eu, neste pedaço, vou erguer um mundão.

A Nega Bina Calcanhar de Frigideira, sorrindo, selou:

- Será a Barra do Catimbó.

E sem mais conversa, os dois se puseram a construir, com as próprias mãos, uma morada. ${ }^{153}$

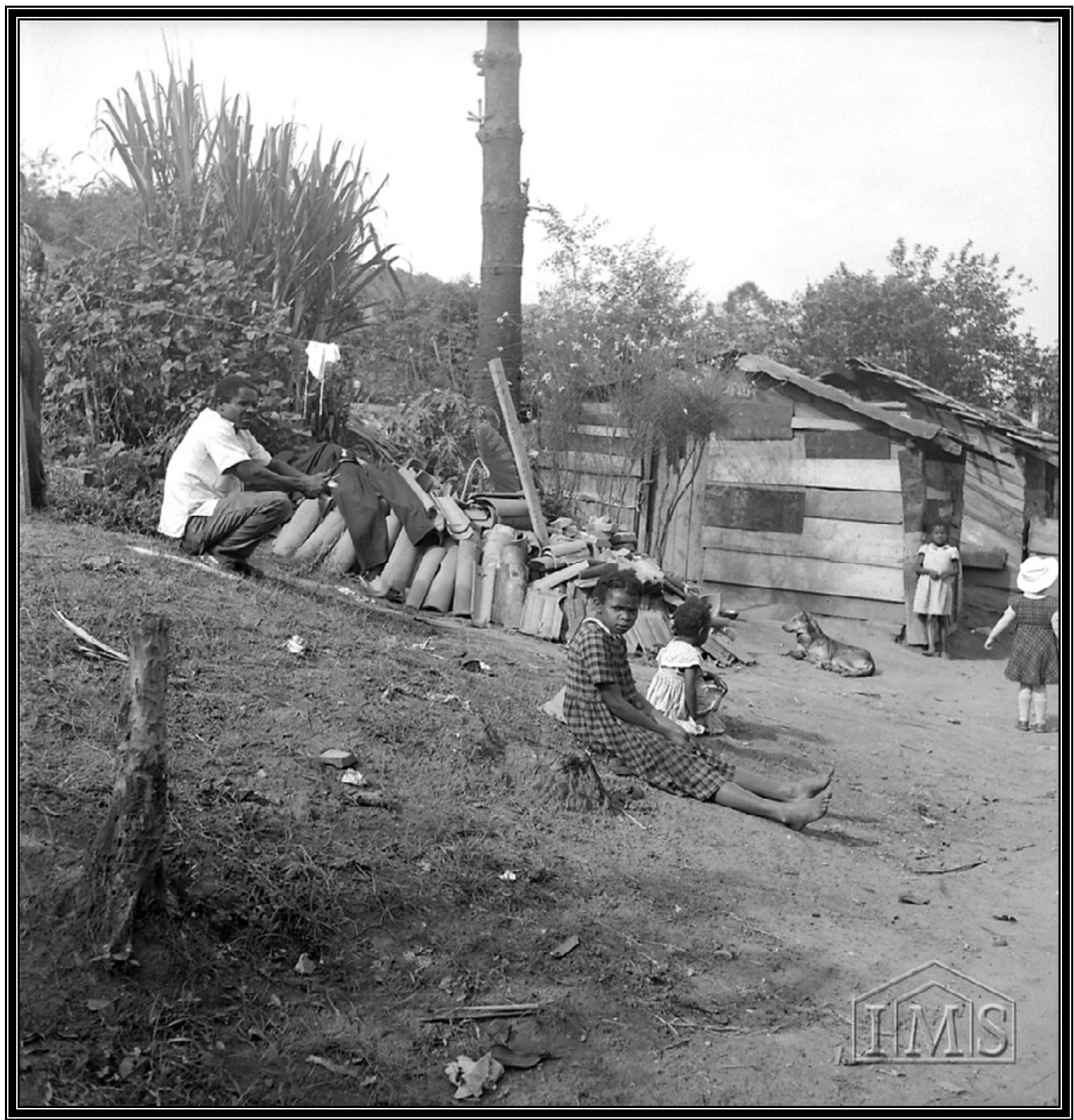

Imagem 12 - Moradas em Santos, SP, 1950.

Alice Brill / Acervo Instituto Moreira Salles. Código: 011AV5806

${ }^{153}$ Plínio Marcos. Na Barra do Catimbó, São Paulo: Global, 1978, pp.14-5. Esse livro traz a história dos personagens que apareceram originariamente nas crônicas que Plínio Marcos escreveu para o Jornal Última Hora de São Paulo no final dos anos 60. Elas foram em parte publicadas em 1973 com o título Histórias das Quebradas do Mundaréu, op. cit. 